\title{
MULHERES NEGRAS E NÃO NEGRAS VIVENDO COM HIV/AIDS NO ESTADO DE SÃO PAULO \\ um estudo sobre suas vulnerabilidades
}

\section{FERNANDA LOPES}

Tese apresentada ao Departamento de Epidemiologia da Faculdade de Saúde Pública da Universidade de São Paulo para obtenção do título de Doutor em Saúde Pública.

Área de concentração: Epidemiologia

Orientadora: Profa. Dra. CASSIA

MARIA BUCHALLA

São Paulo

2003 
Autorizo, exclusivamente para fins acadêmicos e científicos, a reprodução total ou parcial desta tese, por processos fotocopiadores. Ao usá-la, cite a fonte.

Assinatura:

Data: 


\section{DEDICATÓRIA}

Aos meus pais Izaenio Lopes e Vera Lúcia Lopes que, no exercício diário, me ensinaram o valor do amor e da dedicação.

A todas as mulheres negras e não negras que me inspiraram a escrever este trabalho. 


\section{AGRADECIMENTOS}

Ao me deparar com a beleza das manhãs e com os encantos das noites, cada qual em sua unicidade, em sua perfeição, tenho certeza de que fui agraciada com ótimos presentes divinos. A Ele agradeço por minha existência, força e ousadia.

E lá do outro lado do arco-íris estão três fortes guerreiras Irene, Verônica e Goretti que me fizeram compreender o valor da perseverança, a elas faço minhas reverências.

Com o mesmo carinho faço meus agradecimentos:

À professora doutora Cassia Maria Buchalla que, com sua humanidade, amizade e seriedade no desempenho de suas atribuições, soube acolher meus sonhos e contribuir com maestria para que eles pudessem ser transferidos ao papel.

Aos professores doutores José Ricardo Ayres, Ivan França Junior e Vera Paiva que, com muita generosidade, compartilharam seus conhecimentos, suas experiências, suas visões de mundo e me incentivaram (e ajudaram) a trilhar novos caminhos.

À doutora Wilza Villela que, há alguns anos, ainda que sem saber, deu-me o caminho das pedras e me motivou a falar do que hoje eu falo e a encontrar as pessoas que agora fazem parte de minha história, assim como ela.

Ao professor doutor Kabengele Munanga que, há anos tem me oferecido a oportunidade de apreender velhos e novos detalhes sobre as relações raciais no Brasil.

Aos pesquisadores da equipe brasileira do Programa Enhacing Care Iniciative, por concordarem com a cessão dos dados aqui analisados.

A Gislaine Maria da Silva que, com disposição, colaborou na revisão e edição do texto.

Às amigas Maria Dirce Pinho - Dida -, Kelly Oliveira e ao amigo Luís Carlos Lima pelas muitas horas de construção de novos ideais, novas crenças, novos valores, novas atitudes.

À professora doutora Elza Berquó que, com muita paixão pela vida e pelo saber, inspirou-me a percorrer novos e desconhecidos caminhos.

Aos meus companheiros e companheiras do NEPAIDS, especialmente ao Robson Colosio, Neide Silva, Luzia de Oliveira e Carlos Roberto Silva, por seu empenho na construção de um mundo mais justo. 
Aos amigos e amigas que sempre se fizeram presentes, especialmente a Angelita Garcia, Wilma Medeiros, Fabiano Xavier, Érica Bernardes e José Alfredo -Paqüera -, pelas inúmeras horas de conversa, risadas, reflexões...

Aos amigos Magno Souza, Maurílio de Oliveira que, com sua poesia, musicalidade e carisma, deram outros ares e outras luzes aos meus dias (e noites).

Ao amigo Dieudonné Bukasa N’Dala- Dido -, pelo carinho, respeito, companheirismo, solidariedade e paciência.

Ao querido Clayton Rogerio Souza que, com seu espírito de menino atrevido e, em meio a tantas idas e vindas, ausências e atrasos, soube ser companheiro e me fazer acreditar novamente nos sentimentos verdadeiros.

A todos e todas que estiveram e estão presentes em minha vida.

Muito obrigada! 
Lopes F. Mulheres negras e não negras vivendo com HIV/AIDS no estado de São Paulo: um estudo sobre suas vulnerabilidades. São Paulo; 2003. [Tese de Doutorado - Faculdade de Saúde Pública da Universidade de São Paulo].

\section{RESUMO}

Objetivo. A vulnerabilidade individual é estabelecida num espaço de relações entre sujeitos, nesse sentido o estudo buscou compreender a vulnerabilidade de mulheres negras e não negras que vivem com HIV/AIDS à reinfecção e ao adoecimento, em três serviços públicos de referência para o tratamento de DST/AIDS do Estado de São Paulo. Métodos. A pesquisa foi realizada com 1.068 mulheres maiores de 18 anos (526 não negras e 542 negras), voluntárias, atendidas em três serviços públicos de referência para o tratamento de DST/AIDS do Estado de São Paulo, de setembro de 1999 a fevereiro de 2000. As mulheres souberam da pesquisa após contato com a equipe de recepção das instituições, na sala de espera, e aquelas que aceitaram participar assinaram o termo de consentimento pós-informado. $\mathrm{O}$ termo de consentimento e o protocolo de estudo foram aprovados pelos Comitês de Ética de cada uma das instituições participantes. As entrevistas realizaram-se em ambiente privado e foram conduzidas por profissionais do sexo feminino, de nível superior. $\mathrm{O}$ instrumento para coleta de dados foi um questionário semi-estruturado que possibilitava à entrevistada falar sobre suas experiências e impressões em diferentes momentos da vida, especialmente depois da revelação do diagnóstico de soropositividade para o HIV. Na análise estatística utilizou-se o teste qui-quadrado Pearson e intervalos de confiança de 95\%. Para estudar a interação entre as variáveis utilizou-se o modelo loglinear CHAID (Chi-squared Automatic Interaction Detector). Os programas de análise estatística utilizados foram: EpiInfo versão 6.04, SPSS versão 8.0 and Answer Tree ${ }^{\circledR}$ versão 3.0. Resultados. As condições de ordem social que contribuíram mais fortemente para a vulnerabilidade individual de mulheres negras foram: dificuldades de acesso à educação formal, condições de moradia e habitação menos favoráveis, baixo rendimento individual e familiar per capita, responsabilidade pelo cuidado de maior número de pessoas, dificuldade de acesso ao teste diagnóstico, dificuldade de acesso às informações sobre terapia anti-retroviral para o recém-nascido e sobre redução de danos 
no uso de drogas injetáveis, dificuldade em adotar comportamentos protetores - tais como o uso de preservativo -, menores possibilidades de acompanhamento realizado por outro médico que não o infectologista ou ginecologista, menores chances de atendimento nutricional, menos facilidade em obter outros remédios além do coquetel. Os fatores de ordem cognitiva que contribuíram para o aumento da vulnerabilidade das mulheres negras foram: baixa percepção de risco individual de infecção e a conseqüente falta de iniciativa em procurar um serviço de saúde que oferecesse o teste, dificuldade em entender o que os profissionais dizem, em esclarecer suas dúvidas ou falar sobre suas preocupações, dificuldades em entender a evolução de seus quadros clínicos. Os achados permitiram identificar que as mulheres negras estavam menos conscientes sobre o problema e sobre as formas de enfrentá-lo, encontrando, na maioria das situações, menores possibilidades de transformar suas condutas. Do ponto de vista subjetivo, a qualidade do aconselhamento anterior e posterior ao teste, a piora da vida sexual após o diagnóstico e a dificuldade em falar sobre o assunto com os profissionais mais diretamente envolvidos no cuidado, como é o caso dos médicos infectologista e ginecologista, também influenciaram os processos de vulnerabilização. As mulheres não negras apresentaram-se mais atentas em avaliar as situações inadequadas ocorridas no serviço de saúde. Conclusões. Ao incorporar a raça como categoria analítica foi possível compreender melhor a multidimensionalidade, a instabilidade e a assimetria da vulnerabilidade. As experiências e impressões descritas pelas mulheres estudadas apontam a necessidade de reconhecimento das diferenças e de suas especificidades; de investimento no desenvolvimento institucional, nas políticas e programas de formação profissional continuada, com ênfase na humanização do cuidado, na melhoria da qualidade de comunicação e relação interpessoal e na aquisição de habilidades para o manejo de questões inerentes às relações raciais e de gênero. Do mesmo modo, tais experiências ressaltaram a necessidade de ampliação do repertório de direitos que as mulheres dominam para que elas próprias cooperem na redução ou superação de suas vulnerabilidades.

Descritores: raça, mulheres, HIV/AIDS, vulnerabilidade, cuidados em saúde. 
Lopes, F. Black and non-Black women living with HIV/AIDS in São Paulo State: a study on their vulnerabilities. São Paulo; 2003. [Doctoral dissertation - School of Public Health of the University of São Paulo]

\section{SUMMARY}

Objective. Individual vulnerability is established in the context of intersubjective relations. In this sense, the present study sought to compare vulnerability to recurrent infections and illness among women living with HIV/AIDS. Methods. The study group was composed of 1068 volunteers, over 18 years of age (526 non-Black and 542 Black women) being attended by three public services, which are references for the treatment of STD/AIDS within the State of Sao Paulo during the period between September 1999 and February 2000. The women learned of the study by face-to-face contact with the reception staff in the waiting room and those who accepted to participate were asked to sign an informed consent form. The Institutional Ethics Committees of the participating centers approved the consent form and the study protocol. College-level female trained performed interviews in private rooms. Data collection instrument was a semi structured questionnaire that asked participant to express her experiences concerning different time points in her life, especially after she was diagnosed as HIV-infected. Statistical analysis was carried out using Pearson chi-squared test and their corresponding 95\% confidence intervals were calculated using the exact maximum likelihood estimates. Chi-squared Automatic Interaction Detector (CHAID) log linear model was used to study the relationship between variables. EpiInfo version 6.04, SPSS version 8.0 and Answer Tree ${ }^{\circledR}$ version 3.0 software were used. Results. The social conditions which most strongly affected the individual vulnerability of Black women were: difficulties with respect to access to formal education; less favorable living conditions; low individual and family per capita income; responsibility for the care of a greater number of people; problems with respect to diagnostic tests; difficulties with respect to access to information on anti-retroviral therapy for newborns and reducing damage with the use of injected drugs, difficulties in adopting protective behavior, such as the use of condoms, less possibilities of accompaniment by other physicians besides the gynecologist and the specialist in infectious diseases; less opportunities of receiving nutritional orientation; less facilities in obtaining other medicines besides the cocktail. 
The cognitive factors which contributed towards, increasing women's vulnerability were: low degree of awareness as to the individual risk of infection and, consequently, the lack of initiative in looking for a health service which offers HIV testing, difficulties in comprehending the discourse of health professionals and in talking to the latter about their misgivings and their doubts, difficulties in comprehending the evolution of their clinical condition. The finding suggest that Black women living with HIV/AIDS were less aware of their condition and of how to deal with it, encountering, in the majority of cases, less possibilities of transforming their behavior. From a subjective point of view, the quality of counseling activities, the decrease in the quality of their sexual life after diagnosis and the difficulties they faced when discussing these issues with the physicians directly responsible for their care, such as the specialist in infectious diseases and the gynecologist, influenced the process whereby they became increasingly vulnerable. The non-Black women appeared to be more aware of the inadequate situations occurring in the health services. Conclusions. By incorporating race as an analytic category, it was possible to gain a better understanding of the multiple dimensions, the instability and the asymmetry of vulnerability. The experiences and impressions described by the women in this study point towards the necessity of recognizing differences and specificities when investing in institutional development, in policies and in programs geared towards professional training with emphasis on the humanization of care, on the improvement of the quality of communication and of interpersonal relationships and towards the management of issues which are inherent to relationships between "races" groups and between genders. Likewise, they underscore the need to broaden the repertoire of rights these women are aware of so they themselves may cooperate in the reduction of or in the process of overcoming their vulnerabilities.

Key words: race, women, HIV/AIDS, vulnerability, health care. 


\section{APRESENTAÇÃO}

Inicio estas breves linhas afirmando que o tempo é realmente um grande senhor. Ele define novos rumos em nossas vidas e, por mais que tentemos inverter alguns passos, o mundo gira, nos faz retornar e assumir outras faces.

Essa afirmação resume minha pequena trajetória de vida profissional. Como bióloga que sou, trabalhando na área de Saúde Pública e migrando das bancadas de um laboratório de biologia molecular para os estudos sobre promoção e violação do direito à saúde.

Em 1991, quando das minhas primeiras aproximações "oficiais" para junto do movimento negro organizado, a necessidade de encontrar algumas respostas para os questionamentos feitos por mulheres negras me instigavam, especialmente no que dizia respeito às doenças sexualmente transmissíveis e à aids.

Nesse período de 12 anos, me deparei com situações, no mínimo, perturbadoras: a ausência de imagens negras nas campanhas de prevenção; a manutenção do silêncio diante das reivindicações do movimento social de mulheres negras para a inclusão do quesito cor na ficha de notificação dos casos de aids; a inexistência de personagens negros nas histórias de vida relatadas por pesquisadores da área; a insistência das mulheres negras organizadas em falar que a aids não estava pedindo licença para invadir também os corpos negros, especialmente os corpos negros femininos...

Fiquei extremamente incomodada com mais essa invisibilidade oficial e quase "natural" em dois momentos de minha vida: o primeiro foi quando me dei conta de que, das mulheres que se souberam soropositivas para o HIV durante as atividades de minha pesquisa de mestrado, $80 \%$ eram negras; o segundo momento foi durante uma atividade do NEPAIDS - 3 anos após ter iniciado minha participação nesse núcleo -, ocasião em que me senti honrada por ter outras mulheres negras para compartilhar experiências. Esse momento foi um curso de formação de agentes multiplicadores, que contava com a presença de mulheres vivendo com HIV/AIDS e, todas aquelas negras que eu estava radiante em receber, já haviam sido contaminadas pelo HIV. Uma delas, em especial, demonstrava grande insatisfação com o acompanhamento psicológico oferecido pelo serviço especializado de saúde, porque a psicóloga só queria conversar sobre a doença, como se ela não fosse nada antes de ter o vírus; como se ela não sofresse por morar na Zona Leste, por ser uma mulher negra, pobre, com dentes faltando na boca e como se 
ela não pudesse afirmar que a soropositividade the havia agraciado com alguns privilégios que nunca havia desfrutado em toda sua vida, tais como cesta básica, vale transporte, tratamento personalizado no serviço de saúde...

Diante desse cenário, fortaleceu-se em mim o desejo de estudar o universo "colorido" da aids entre as mulheres. As experiências vividas e a preocupação em não vitimizar essas mulheres guerreiras por "natureza", me conduziram a optar por referenciais teóricos mais abrangentes e menos lineares. Foi assim que optei por realizar um estudo sobre vulnerabilidades.

$\mathrm{Na}$ intenção de contribuir para elaboração de ações mais equânimes e para a implementação de práticas de saúde emancipatórias, faço um convite àqueles e àquelas que estiverem dispostos a entrar no "mutirão": embrenhem-se nas redes da vulnerabilidade e encontrem caminhos para sua redução ou superação, lembrando que, desde que haja vida, pouquíssimas situações são intransponíveis. 


\section{ÍNDICE}

1. INTRODUÇÃO

1.1 A Aids no Mundo 1

1.1.1 Sem limites ou fronteiras intransponíveis: a distribuição da infecção e da doença pelo mundo 2

1.2 A Dinâmica da Aids no Brasil 6

1.2.1 Mudanças no perfil de casos

$\begin{array}{ll}1.2 .2 \text { A face paulista da epidemia } & 10\end{array}$

1.3 Na Roda dos Expostos: as Mulheres e a Aids 13

1.3.1 Relações de gênero(s), exercício da sexualidade e aids $\quad 15$

$\begin{array}{ll}1.3 .2 \text { Vidas positivas } & 16\end{array}$

1.4 Vulnerabilidade: um Quadro Teórico-conceitual 17

1.4.1 A "emergência" do termo vulnerabilidade no campo da aids $\quad 17$

1.4.2 Da noção de risco à noção de vulnerabilidade $\quad 18$

1.4.3 As dimensões da vulnerabilidade 19

1.4.4 Horizontes práticos do conceito e demais aspecto agregados $\quad 20$

1.4.4. 1 O conceito de raça 22

1.4.4.2 A noção de racismo $\quad 24$

1.4.4.3 Desigualdades raciais no Brasil 25

2. AIDS E POPULAÇÃO NEGRA: A RELEVÂNCIA DA PESQUISA COM MULHERES

3. OBJETIVOS 34

3.1 Objetivo Geral 34

3.2 Objetivos Específicos 34

4. SUJEITOS, MATERIAL E MÉTODOS 35

4.1 Antecedentes: Programa Enhancing Care Initiative (ECI-Brasil) 35

4.1.1 Delineamento da pesquisa multicêntrica 36

4.1.1.1 População acessivel 36

4.1.1.2 Critérios de inclusão $\quad 36$

4.1.1.3 Cálculo da amostra $\quad 36$

4.1.1.4 Caracterização das recusas $\quad 37$

4.1.1.5 População sob estudo 38

4.1.1.6 Instrumentos para coleta de dados 38

4.1.1.7 Aspectos éticos 39

4.2 Desenvolvimento do Presente Trabalho 39

4.2.1 Variáveis de estudo $\quad 40$

4.2.1.1 Variáveis sociodemográficas $\quad 40$

4.2.1.2 Variáveis relacionadas ao teste e aos cuidados recebidos $\quad 41$

4.2.1.3 Variáveis relacionadas à vida sexual 43

4.2.1.4 Variáveis relacionadas ao serviço de saúde, acesso e
acolhimento

4.2.1.5 Variáveis que caracterizam a relação com o serviço e os cuidados com a saúde 
4.3 Tratamento Estatístico $\quad 45$

4.3.1 Análise univariada $\quad 45$

4.3.2 Análise multivariada utilizando a técnica CHAID 46

4.3.2.1 Razões para a escolha da técnica 46

4.3.2.2 A técnica CHAID 46

4.3.2.3 Parâmetros estabelecidos para o uso da técnica e

5. RESULTADOS 52

5.1 Análise Univariada $\quad 52$

5.1.1 Características sociodemográficas $\quad 52$

5.1.2 Teste e cuidados recebidos $\quad 57$

5.1.3 Vida sexual 63

5.1.4 Serviço de saúde: acesso e acolhimento 66

5.1.5 Relação com o serviço e cuidados com a saúde $\quad 69$

5.1.6 Síntese dos resultados da análise univariada $\quad 71$

5.2 Análise Multivariada Utilizando a Técnica CHAID 73

5.2.1 Estudo das variáveis-resposta relacionadas ao cuidado anterior e, imediatamente, posterior à testagem $\quad 73$

5.2.2 Estudo das variáveis-resposta relacionadas às sensações e atitudes individuais após o diagnóstico de soropositividade para o HIV 84

5.2.3 Estudo das variáveis-resposta relacionadas à vida sexual após o diagnóstico de soropositividade para o HIV 93

5.2.4 Estudo das variáveis-resposta relacionadas ao vínculo com o serviço de saúde especializado e à qualidade do cuidado $\quad 97$

5.3 Síntese dos Resultados da Análise Multivariada 118

6. DISCUSSÃO 122

6.1 Limites e Possibilidades de Erro 122

6.1.1 Delineamento ou desenho da investigação 122

6.1.2 Amostragem $\quad 122$

6.1.3 Instrumentos para coleta de dados $\quad 122$

6.1.4 Entrevistadoras $\quad 123$

6.1.5 Entrevistadas $\quad 123$

6.1.6 Informação 123

6.1.7 Método estatístico utilizado para análise multivariada $\quad 124$

$\begin{array}{ll}6.1 .8 \text { Inferência } & 125\end{array}$

6.1.9 Validade externa $\quad 125$

6.1.10 A opção pela cor auto-referida $\quad 126$

6.1.11 Validade das categorias e terminologia racial adotadas $\quad 128$

6.2 Discutindo os Resultados Encontrados 129

6.2.1 Desigualdades sociais geradoras de vulnerabilidades:

$\begin{array}{ll}\text { características gerais da amostra } & 129\end{array}$

6.2.1.1 Raça/cor $\quad 129$

$\begin{array}{ll}6.2 .1 .2 \text { Idade } & 129\end{array}$

$\begin{array}{ll}6.2 .1 .3 \text { Escolaridade } & 130\end{array}$

6.2.1.4 Moradia e habitação $\quad 130$

6.2.1.5 Ocupação 131 
6.2.1.6 Renda individual e familiar

6.2.2 Relações intersubjetivas e vulnerabilidades

6.2.2.1 A intersecção das trajetórias individuais: categorias de exposição ao HIV e motivos para a realização do teste

6.2.2.2 Mudando (ou não) o rumo da história: vida sexual após o diagnóstico

6.2.2.3 Discriminação racial nas práticas de saúde: realidade ou ilusão?

6.2.2.4 Relação com o serviço de saúde onde se trata atualmente

7. CONSIDERAÇÕES FINAIS E RECOMENDAÇÕES

\section{ANEXOS}

I. Ata de aprovação do projeto ECI-Brasil pela Comissão de Ética

II. Termo de consentimento pós-informação

III. Ata de aprovação do projeto de pesquisa pelo Comitê de Ética

IV. Instrumento para coleta de dados 


\section{LISTA DE TABELAS}

Tabela 1. Posição assumida pelo Índice de Desenvolvimento Humano brasileiro diante do ranking mundial, segundo cor e grande região. Brasil, 1997-1999.

Tabela 2. Índice de Rendimento Médio Mensal, segundo raça e sexo. Brasil, regiões metropolitanas, 1998 .

Tabela 3. Distribuição de freqüência e porcentagem de mulheres portadoras de HIV, por categoria de participação no estudo, segundo local de atendimento. São Paulo, 2000.

Tabela 4. Distribuição de freqüência e porcentagem de mulheres soropositivas na fase de pré-testagem de instrumentos, segundo local de atendimento. São Paulo, 1999.

Tabela 5. Distribuição da população por faixa etária e nível de escolaridade, segundo raça/cor. São Paulo, 2000.

Tabela 6. Distribuição da população por condições de moradia e habitação, segundo raça/cor. São Paulo, 2000.

Tabela 7. Distribuição da população por ocupação, segundo raça/cor. São Paulo, 2000.

Tabela 8. Distribuição da população por renda individual, renda familiar per capita e contribuição para o orçamento familiar, segundo raça/cor. São Paulo, 2000.

Tabela 9. Distribuição da população por tempo de infecção diagnosticada e por faixa etária no momento do diagnóstico, segundo raça/cor. São Paulo, 2000 .

Tabela 10. Distribuição da população segundo razão da testagem e raça/cor. São Paulo, 2000.

Tabela 11. Distribuição da população por categoria de exposição, segundo raça/cor. São Paulo, 2000.

Tabela 12. Distribuição da população por características relacionadas ao processo de aconselhamento, segundo raça/cor. São Paulo, 2000.

Tabela 13. Informações recebidas em serviços especializados no tratamento/acompanhamento de pessoas vivendo com HIV/AIDS, segundo raça/cor. São Paulo, 2000. 
Tabela 14. Distribuição da população por características relacionadas à vida sexual após o diagnóstico, segundo raça/cor. São Paulo, 2000.

Tabela 15. Distribuição da população por características relacionadas à vida sexual com parceiro fixo atual, segundo raça/cor. São Paulo, 2000.

Tabela 16. Características do cuidado recebido no serviço de saúde especializado, segundo raça/cor. São Paulo, 2000.

Tabela 17. Comunicação com o infectologista do serviço especializado, segundo raça/cor. São Paulo, 2000.

Tabela 18. Comunicação com o ginecologista do serviço especializado, segundo raça/cor. São Paulo, 2000.

Tabela 19. Relação com o serviço e cuidados com a saúde, segundo raça/cor. São Paulo, 2000. 


\section{LISTA DE QUADROS}

Quadro 1. Variáveis estudadas na análise multivariada utilizando a técnica CHAID

Quadro 2. Fatores estatisticamente relevantes para o estudo das variáveis dependentes relacionadas ao cuidado de mulheres negras e não negras vivendo com HIV/AIDS 


\section{LISTA DE FIGURAS}

Figura 1. Renda individual mediana e renda familiar per capita mediana, 56 segundo raça/cor. São Paulo, 2000

Figura 2. Fatores estatisticamente relacionados à razão da testagem para mulheres negras vivendo com HIV/AIDS. São Paulo, 2000.

Figura 3. Fatores estatisticamente relacionados à razão da testagem para mulheres não negras vivendo com HIV/AIDS. São Paulo, 2000.

Figura 4. Fatores estatisticamente relacionados ao aconselhamento pré-teste oferecido para mulheres negras vivendo com HIV/AIDS. São Paulo, 2000.

Figura 5. Fatores estatisticamente relacionados ao aconselhamento pré-teste oferecido para mulheres não negras vivendo com HIV/AIDS. São Paulo, 2000 .

Figura 6. Fatores estatisticamente relacionados à atitude do profissional que entregou o resultado do teste às mulheres negras vivendo com HIV/AIDS. São Paulo, 2000.

Figura 7. Fatores estatisticamente relacionados à atitude do profissional que entregou o resultado do teste às mulheres não negras vivendo com HIV/AIDS. São Paulo, 2000.

Figura 8. Fatores estatisticamente relacionados à sensação descrita por mulheres negras vivendo com HIV/AIDS no momento da entrega do resultado do teste. São Paulo, 2000.

Figura 9. Fatores estatisticamente relacionados à sensação descrita por mulheres não negras vivendo com HIV/AIDS no momento da entrega do resultado do teste. São Paulo, 2000.

Figura 10. Fatores estatisticamente relacionados ao tempo que mulheres negras vivendo com HIV/AIDS demoraram em procurar o serviço de saúde especializado. São Paulo, 2000.

Figura 11. Fatores estatisticamente relacionados ao tempo que mulheres não negras vivendo com HIV/AIDS demoraram em procurar o serviço de saúde especializado. São Paulo, 2000.

Figura 12. Fatores estatisticamente relacionados ao uso de preservativo após o diagnóstico de infecção pelo HIV para mulheres negras. São Paulo, 2000. 
Figura 13. Fatores estatisticamente relacionados ao uso de preservativo após o diagnóstico de infecção pelo HIV para mulheres não negras. São Paulo, 2000 .

Figura 14. Fatores estatisticamente relacionados à facilidade descrita por mulheres negras vivendo com HIV/AIDS em obter outros remédios além do coquetel. São Paulo, 2000.

Figura 15. Fatores estatisticamente relacionados à facilidade descrita por mulheres não negras vivendo com HIV/AIDS em obter outros remédios além do coquetel. São Paulo, 2000.

Figura 16. Fatores estatisticamente relacionados à facilidade descrita por mulheres negras vivendo com HIV/AIDS para entender o que o infectologista diz. São Paulo, 2000.

Figura 17. Fatores estatisticamente relacionados à facilidade descrita por mulheres não negras vivendo com HIV/AIDS para entender o que o infectologista diz. São Paulo, 2000.

Figura 18. Fatores estatisticamente relacionados à facilidade descrita por mulheres negras vivendo com HIV/AIDS para entender o que o ginecologista diz. São Paulo, 2000.

Figura 19. Fatores estatisticamente relacionados à facilidade descrita por mulheres não negras vivendo com HIV/AIDS para entender o que o ginecologista diz. São Paulo, 2000.

Figura 20. Fatores estatisticamente relacionados à facilidade descrita por mulheres negras vivendo com HIV/AIDS para falar sobre sua vida sexual com o infectologista. São Paulo, 2000.

Figura 21. Fatores estatisticamente relacionados à facilidade descrita por mulheres não negras vivendo com HIV/AIDS para falar sobre sua vida sexual com o infectologista. São Paulo, 2000.

Figura 22. Fatores estatisticamente relacionados à facilidade descrita por mulheres negras vivendo com HIV/AIDS para falar sobre sua vida sexual com o ginecologista. São Paulo, 2000.

Figura 23. Fatores estatisticamente relacionados à facilidade descrita por mulheres não negras vivendo com HIV/AIDS para falar sobre sua vida sexual com o ginecologista. São Paulo, 2000. 


\section{LISTA DE SIGLAS E ABREVIATURAS}

AIDS - Síndrome da Imunodeficiência Adquirida

AIDSCAP - Aids Control and Prevention Project

BENFAM - Sociedade Civil Bem-Estar Familiar no Brasil

CAIDS/FMUSP - Casa da Aids da Divisão de Moléstias Infecciosas e Parasitárias da Faculdade de Medicina da Universidade de São Paulo

CD4 - Linfócitos TCD4

CDC - Centers for Disease Control and Prevention

CEBRAP - Centro Brasileiro de Análise e Planejamento

CI - Coeficiente de Incidência

CN-DST/AIDS - Coordenação Nacional de DST/AIDS

CRAIDS - Centro de Referência em Aids

CRT-DST/AIDS - Centro de Referência e Treinamento em DST/AIDS

DST - Doença Sexualmente Transmissível

ECI - Enhacing Care Iniciative

EUA - Estados Unidos da América

HIV - Vírus da Imunodeficiência Humana

HPV - Pappilomavirus Humano ou Vírus do Papiloma Humano

HSH - Homem que faz Sexo com Homem

IBGE - Instituto Brasileiro de Geografia e Estatística

IDG - Índice de Desenvolvimento Humano ajustado ao Gênero

IDH - Índice de Desenvolvimento Humano

INSPIR - Instituto Sindical Interamericano pela Igualdade Racial

IPEA - Instituto de Pesquisa Econômica Aplicada

IST - Infecção Sexualmente Transmissível

MS - Ministério da Saúde

MVA - Mulheres Vivendo com HIV/AIDS

NEPAIDS/USP - Núcleo de Estudos para Prevenção da Aids da Universidade de São Paulo

OPAS - Organização Panamericana de Saúde

p - nível descritivo do teste de associação pelo Qui-quadrado

PE-DST/AIDS - Programa Estadual de DST/AIDS

PM-DST/AIDS - Programa Municipal de DST/AIDS

PNAD - Pesquisa Nacional de Domicílios

PNDS - Pesquisa Nacional de Demografia e Saúde 
PROAIM - Programa de Aprimoramento das Informações de Mortalidade no Município de São Paulo

PVHA - Pessoas Vivendo com HIV/AIDS

SES-SP - Secretaria de Estado da Saúde - São Paulo

SMS - Secretaria Municipal de Saúde

SUS - Sistema Único de Saúde

UDI - Usuário(a) de Drogas Injetáveis

UNAIDS - Joint United Nations Programme on HIV/AIDS. 
Todo problema humano deve ser considerado a partir do tempo. Se pertenço irredutivelmente à minha época, é para ela que devo viver. Logo, o futuro deve ser uma construção contínua do homem que existe e esta construção/edificação é ligada ao presente, na medida em que o coloco como algo a ser superado.

Frantz Fanon (1925-1961)

(Pele Negra, Máscaras Brancas. Rio de Janeiro: Fator, 1983) 


\section{INTRODUÇÃO}

\subsection{A Aids ${ }^{1}$ no Mundo}

Os primeiros relatos sobre um conjunto de doenças oportunistas incomuns foram descritos em 1981 e envolviam homens jovens, previamente saudáveis, com comportamento homossexual. A doença foi relacionada à infecção pelo Vírus da Imunodeficiência Adquirida - HIV e, ao conjunto de sintomas, deu-se o nome Síndrome da Imunodeficiência Adquirida - AIDS ou SIDA.

Desde a descoberta da infecção e de suas consequiências, houve acúmulo de conhecimento registrado em produções acadêmicas e transferido às populações por meio de políticas públicas e ações de prevenção, cuidado e assistência; houve também inúmeros avanços no campo da terapêutica medicamentosa. Contudo, o aumento no número de pessoas infectadas persiste, particularmente nos países subdesenvolvidos ou "em desenvolvimento".

A dualidade "desenvolvidos versus subdesenvolvidos" contribui para que as estatísticas globais da aids sejam assustadoras e díspares. De acordo com a UNAIDS (2002b) estima-se que tenham ocorrido 5 milhões de novas infecções e 3,1 milhões de óbitos durante o ano de 2002. Acredita-se que 3,5 milhões das novas infecções e 2,4 milhões dos óbitos tenham ocorrido nos países da África sub-saariana. Até dezembro daquele ano, aproximadamente, 42 milhões de pessoas viviam com HIV/AIDS (29,4 milhões na África sub-saariana).

Para além das conexões aids-subdesenvolvimento; aids-pobreza; aidsinsegurança/instabilidade econômica que estão subtraindo vidas, chama a atenção a perda de vidas femininas. Por diversas razões, tais como a falta de poder, falta de informação e acesso aos recursos preventivos, exploração sexual por razões comerciais, a proporção de mulheres vivendo com HIV/AIDS vem aumentando contundentemente, embora o maior contingente de infectados e doentes ainda seja masculino.

\footnotetext{
${ }^{1}$ A Coordenação Nacional de DST/AIDS do Ministério da Saúde deliberou que a palavra aids deve ser considerada substantivo comum, apesar de ser originária de uma sigla estrangeira. Dessa forma, quando se tratar da epidemia, sua grafia será sempre em letras minúsculas, como postulado para outros agravos. Quando for nome de um setor ou título, a primeira letra será maiúscula e as demais minúsculas. Por exemplo: Coordenação Nacional de DST e Aids. Entretanto, quando o termo estiver junto de outras siglas escritas com letras maiúsculas, sua grafia seguirá a mesma regra. Por exemplo: CN-DST/AIDS.
} 
Em 1998, a proporção de mulheres adultas infectadas era de $41,1 \%(\cong 10,5$

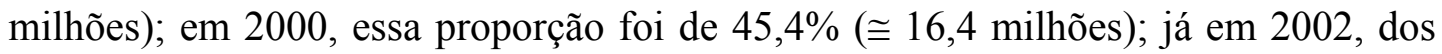
38,6 milhões de adultos infectados, 19,2 milhões eram mulheres, ou seja, 49,7\% do total (UNAIDS, 1998, 2000, 2002b). Com o aumento do número de infecções ou de casos notificados entre as mulheres, sobretudo entre aquelas que estão em idade fértil, vêm aumentando as taxas de transmissão durante a gravidez, parto ou aleitamento materno e, como num ciclo vicioso, mais vidas acabam sendo subtraídas em menos tempo.

\subsubsection{Sem limites ou fronteiras intransponíveis: a distribuição da infecção e da doença pelo mundo}

\section{Ásia e Ilhas do Pacífico}

Os primeiros casos notificados nos países da Ásia e nas Ilhas do Pacífico datam do final da década de 80. Até dezembro de 2002 eram estimadas 7,2 milhões de pessoas vivendo com HIV (2,1 milhões de jovens entre 15 e 24 anos). Oitenta e três por cento dos casos notificados na região estão nos países do sul e sudeste asiático e o restante nos países da Ásia Oriental e nas Ilhas do Pacífico. Dentre os casos notificados no sul e sudeste asiático, 36\% eram mulheres; e nos países da Ásia Oriental e nas Ilhas do Pacífico, 24\% (UNAIDS, 2002b).

Com exceção do Camboja, Mianmar e da Tailândia, os níveis de prevalência nacional são baixos, quando comparados com o restante do mundo. Essa característica, no entanto, não é confortável, porque em países populosos como China, Índia e Indonésia, as baixas taxas de prevalência nacional representam um grande número de casos e afetam milhões de pessoas (UNAIDS, 2002b).

$\mathrm{Na}$ Índia, onde a prevalência de infecção na população adulta é menor que 1,0\%, entretanto estimou-se que 3,97 milhões de pessoas viviam com HIV até o final de 2001, o que corresponde à segunda maior soma de pessoas infectadas no mundo. $\mathrm{Na}$ China, em meados de 2002, estimou-se que 1 milhão de pessoas vivia com HIV e, para comprovar o crescimento abrupto das infecções, a UNAIDS (2002b) destacou que $17,0 \%$ dos novos casos foram registrados nos seis primeiros meses daquele ano.

Os fatores que facilitam a disseminação do HIV estão presentes em toda região, mas alguns grupos têm sido afetados de maneira especial: usuários de drogas 
injetáveis (UDI), trabalhadores do sexo e homens que fazem sexo com homens (UNAIDS, 2002a, 2002b).

\section{Europa Oriental e Ásia Central}

Na Europa Oriental e Ásia Central, embora os primeiros casos tenham sido identificados no início dos anos 90, aproximadamente, 1,2 milhões de pessoas vivem com HIV/AIDS. Em 2002 foram notificadas 250 mil novas infecções, das quais 200 mil ocorreram nos países que formavam a antiga União Soviética (atual Federação Russa).

Com uma taxa de prevalência de $0,6 \%$ na população adulta e uma razão de sexo de 2,7 homens para 1 mulher, adultos e jovens dessa região estão expostos à infecção, prioritariamente pelo uso de drogas injetáveis. Como essa prática é freqüente na população jovem (em algumas regiões mais de $80,0 \%$ dos casos têm, no máximo, 29 anos) e pelo fato de muitas mulheres jovens manterem relações sexuais em troca de dinheiro, começam a emergir os casos de transmissão pela via sexual: das notificações ocorridas em 2002, 28\% foram incluídas na categoria sexual de exposição (UNAIDS, 2002b).

\section{África Sub-saariana}

A África sub-saariana é a região do mundo mais afetada pela epidemia e agrega, aproximadamente, 29,4 milhões de pessoas infectadas, dentre elas 10 milhões de jovens de 15 a 24 anos e cerca de 3 milhões de crianças com menos de 15 anos.

É notável a ausência de políticas públicas que minimizem a possibilidade de infecção e melhorem a qualidade de vida daqueles que já foram infectados dado que, na região, a epidemia tornou-se visível ainda no período que compreende o final da década de 70 e o início dos anos 80 , e que, desde então, apresenta um padrão de disseminação, prioritariamente, heterossexual.

A parcela da população direta ou indiretamente afetada pela aids sofre com pobreza disseminada, com as guerras e as altas taxas de migração, além das dificuldades de acesso aos recursos preventivos, aos anti-retrovirais e aos medicamentos para doenças oportunistas, o que confere uma estúpida força à epidemia: em alguns países, a devastação causada pelo HIV é assustadora: em Botsuana, 38,8\% da população é soropositiva, no Zimbábue, 33,7\%, na Suazilândia, 
33,4\% e, em Lesoto, 31\%. Na África do Sul, a cada 9 habitantes 1 é portador do HIV (UNAIDS, 2002a, 2002b).

A complexidade da epidemia na África sub-saariana afeta nomeadamente as mulheres e, de modo especial, as jovens. seja em decorrência dos conflitos armados e da ampliação da possibilidade de violência e comércio sexual ou das necessidades impostas pela nova realidade econômica.

Em geral, as mulheres são, comumente, discriminadas no acesso à educação formal, no mercado de trabalho, no cuidado à saúde e no direito à propriedade e à herança e, em decorrência disso, tanto as relações casuais como aquelas que visam o casamento, são vistas como oportunidades de segurança social e financeira ou como meios para a satisfação de aspirações materiais pessoais e familiares. Caberia aqui a observação feita por Santos M (2000) sobre os novos conteúdos e as novas definições da pobreza. Segundo o autor, a pobreza (e as estratégias utilizadas para combatê-la) ganha(m) novo(s) significado(s) quando a ampliação das possibilidades de consumo determina ou aponta para novas condições materiais, psicológicas e psicossociais. Estas imposições "globalizadas" são observadas com mais nitidez nas populações urbanas.

Além disso, as mulheres jovens tendem a iniciar sua vida sexual com pouca idade e a relacionar-se, com homens mais velhos, o que lhes confere maiores riscos de infecção por IST, incluindo o HIV. Estes riscos também são ampliados nas áreas de conflito armado onde são comuns tanto o comércio sexual quanto a violência e o abuso (Gilbert e Walker, 2002; UNAIDS, 2002a, 2002b).

\section{América Latina e Caribe}

Até o final de 2002, a UNAIDS estimou que 1,9 milhões de adultos e crianças viviam com HIV/AIDS na América Latina e Caribe. Em 12 países da região, a taxa de prevalência entre mulheres grávidas foi de 1,0\%, não obstante, em alguns países do Caribe, como é o caso do Haiti e das Bahamas, o número de pessoas infectadas só foi superado pela África sub-saariana. A melhor situação foi descrita para a República Dominicana, que teve a prevalência de infecção reduzida na população de mulheres grávidas, conforme as observações feitas em estudos sentinelas (UNAIDS, 2002b). 
O aumento do número de casos notificados na população feminina tem contribuído para a diminuição da razão de sexo: em 2002, a razão na América Latina era de 3 homens para 1 mulher e, no Caribe, 1 mulher para 2 homens. A grande proporção de usuários de drogas injetáveis e a constatação de que os homens que fazem sexo com outros homens também o fazem com mulheres são evidências do fenômeno denominado feminização da epidemia (OPAS, 2002; UNAIDS, 2002b).

\section{Norte da África e Oriente Médio}

Existem poucas informações acerca dos números da aids no norte da África e no Oriente Médio. É sabido que nessas regiões a exposição ocorre, prioritariamente, pela via heterossexual e pelo uso de drogas injetáveis, que, até o ano 2000, tinha um número de notificações de 400 mil casos e que, em dezembro de 2002, esse número passou para 550 mil. Dos casos notificados na população adulta, 40\% eram mulheres em 2000 e 55\% em 2002. Também foi estimado que 83 mil pessoas podem ter se infectado durante o ano de 2002 (UNAIDS, 2000, 2002b).

\section{América do Norte e Europa Ocidental}

Durante o último ano, cerca de 76 mil pessoas foram contaminadas pelo HIV nos países desenvolvidos, particularmente os localizados na América do Norte e Europa Ocidental. Somados aos sabidamente HIV positivo estima-se que, nessas regiões, vivam 1,6 milhões de portadores. Recentemente, esses países conviveram com muitas mudanças na epidemia, sobretudo porque a introdução da terapia antiretroviral contribuiu tanto para o incremento do número de pessoas vivendo com a doença quanto para a diminuição nas taxas de mortalidade - em 2001, cerca de 500 mil portadores recebiam medicamentos (UNAIDS, 2002b).

Em relação aos canais de infecção, 59,0\% dos casos notificados na Europa Ocidental foram contaminados em relações heterossexuais. Em alguns países é freqüente o compartilhamento de agulhas e seringas no uso de drogas, em função disso, a prevalência de infecção entre os UDIs é alta: 20-30\% na Espanha; 10-23\% na França. Em Portugal, dos casos notificados entre 2000 e 2001, a metade era de UDI. De acordo com a UNAIDS (2002b), a população jovem desses países está sendo notadamente atingida pela epidemia.

Nos estados da América do Norte, as desigualdades sociais, raciais, étnicas e de gênero têm contribuído marcadamente para a disseminação da aids. Nos Estados 
Unidos, $54,0 \%$ das infecções adquiridas no ano 2000 ocorreram entre os afroamericanos, embora o grupo representasse apenas $13,0 \%$ da população nacional no mesmo ano. Com o mesmo grau de importância observa-se que mais da metade dos casos reportados entre julho de 2000 e junho de 2001 eram de adolescentes de 13 a 19 anos, do sexo feminino (CDC, 2001).

Sessenta e quatro por cento das mulheres diagnosticadas em 2001 eram negras; também dentre os homens que faziam sexo com outros homens, a maioria dos infectados era negra. Disparidades étnicas na disseminação do HIV também foram registradas no Canadá: em 1999, 9\% das infecções foram atribuídas aos aborígines, embora, naquela época, eles representassem menos de $3 \%$ da população nacional (CDC, 2001; UNAIDS, 2002b).

\subsection{A Dinâmica da Aids no Brasil}

No Brasil, a principal fonte de informações sobre aids é a vigilância epidemiológica, não obstante, vários fatores têm impedido que a notificação seja mais completa, dentre eles estão: as persistentes revisões dos critérios de definição de casos de aids em adultos e crianças ao longo do tempo, a baixa capacidade de diagnóstico, a subnotificação, o atraso nas notificações e no processamento das informações (Buchalla, 1993, 1995; Mann e col., 1996; Ferreira, 2000; Lemos e Valente, 2001; MS, 2002a).

Notificada no país no início da década de 80, a aids inicialmente esteve associada aos homens adultos, com comportamento homossexual, elevado nível socioeconômico, residentes dos grandes centros urbanos, prioritariamente São Paulo e Rio de Janeiro; bem como aos hemofílicos e àqueles que se beneficiavam de hemoderivados. Os usuários de drogas, mais diretamente afetados no período subseqüente, desempenharam papel central no processo de expansão para as demais localidades do país, grupos etários e também para as mulheres.

Em um país com tantas heterogeneidades sociogeográficas, a ampla difusão da epidemia não lhe confere uniformidade, pelo contrário, permite que ela seja reconhecida como um conjunto de inúmeras microepidemias regionais (Buchalla, 1995; Szwarcwald e col., 2000; MS, 1998, 2000, 2002a; Barbosa e col., 2000). A diversidade no padrão de disseminação apresenta-se como grande desafio para o 
acompanhamento de seu curso e para a implementação de políticas de prevenção e assistência.

Estima-se que cerca de 600 mil pessoas vivam com HIV/AIDS no Brasil (Szwarcwald e Castilho, 1998). Entretanto, de 1980 até 30 de julho de 2002, haviam sido registrados 237.588 casos (MS, 2002a), ou seja, mais de $60 \%$ dos portadores desconhecem sua condição sorológica.

Dos casos notificados, 67,3\% são de residentes na região Sudeste, 16,4\% na região Sul, 9,4\% na região Nordeste, $5,1 \%$ na região Centro-Oeste e $1,8 \%$ na região Norte. Os estados de São Paulo, Rio de Janeiro, Rio Grande do Sul, Minas Gerais, Paraná e Santa Catarina, concentram $82,6 \%$ do total de notificações desde o início da epidemia (MS, 2002a).

No que diz respeito à distribuição espacial, a epidemia difundiu-se a partir das principais metrópoles em direção aos municípios de médio e pequeno porte que, via de regra, dispõem de menos recursos no âmbito da saúde ou no âmbito comunitário em geral. Embora o processo de disseminação apresente-se numa lógica hierárquica, de acordo com a organização da malha municipal, ele tem sido seletivo quanto ao grau de urbanização dos municípios, privilegiando aqueles com características predominantemente urbanas, com as maiores densidades demográficas e que estão sob interação mais intensa com as demais localidades - seguindo as rotas do sistema rodoviário, ferroviário ou aéreo e as rotas instituídas pelo deslocamento sazonal dos trabalhadores (Szwarcwald e Castilho, 1998; Brito e col., 2000; Szwarcwald e col., 2000).

No que tange à tendência temporal de disseminação da epidemia, a partir de 1999, tem-se verificado uma redução relativa nas taxas de incidência nacional. Essa tendência provavelmente deriva do relativo esgotamento do contingente de susceptíveis (Gupta e col., 1989), da implementação de medidas preventivas (MS, 2002a), da mudança espontânea de comportamento de certos segmentos populacionais (MS/CEBRAP, 2000; Pinho e col., 2002), do impacto de programas de intervenção e controle e do acesso universal e gratuito à terapia anti-retroviral (MS, 2002a). Apesar disso, é importante destacar que a redução não tem ocorrido de forma homogênea, seja do ponto de vista dos seguimentos populacionais mais diretamente afetados, seja das diferentes regiões geográficas. De acordo com Brito e col. (2000) e 
Szwarcwald e col. (2000), a velocidade de expansão tem decrescido basicamente entre os homens das cidades de maior porte, especialmente aquelas localizadas na região Sudeste; contudo, os usuários de drogas injetáveis (e suas parceiras) persistem sendo afetados de modo desproporcional.

\subsubsection{Mudanças no perfil de casos}

A epidemia que, na primeira década mantivera-se, fundamentalmente, restrita às áreas metropolitanas de região Sudeste, aos homens que fazem sexo com outros homens (HSH), aos hemofílicos, aos hemotransfundidos e aos UDIs, vem crescendo de forma considerável entre as mulheres em decorrência da transmissão heterossexual. Desde 1993, essa passou a ser a principal modalidade de exposição ao HIV para o conjunto de casos notificados, superando as categorias "homo" e "bissexual".

Analisando os casos em indivíduos com 13 anos de idade ou mais observa-se que, entre os homens, os casos da subcategoria "heterossexual" superam a soma das categorias "homossexual" e "bissexual" apenas no ano 2000, ao passo que, entre as mulheres, essa subcategoria de exposição sempre foi a principal (MS, 2002a). Essa "heterossexualização" da epidemia é apenas um reflexo do comportamento da população que, em sua maioria, é heterossexual (MS/CEBRAP, 2000).

Em todos os países do mundo, ao longo da última década, o aumento do número de casos na população feminina tem chamado a atenção (UNAIDS, 1998, 2000, 2002a; OPAS, 2002). Embora seja um fenômeno mundial, em nenhum outro lugar a feminização da epidemia foi tão rápida quanto no Brasil (PANOS, 1993; Parker e Galvão, 1996; Barbosa e Villela, 1996; MS, 1998, 2000, 2002a, 2002b).

No período de 1980 a 1990, a razão de casos entre homens e mulheres era de 6,5:1 (em média); no período de 1991 a 2001 a razão passou a 2,4:1. A redução foi consistente em todas as faixas etárias, com destaque aos jovens de 13 a 24 anos e aos menores de 13. Nessas faixas etárias, a razão de casos entre homens e mulheres é praticamente de 1:1, com sinais de inversão na faixa de 13 a 19 anos em 2000 e 2001 $-0,8: 1$ e $0,6: 1$, respectivamente (MS, 2002a, 2002b).

Outra característica do processo de mudança no perfil da epidemia é o persistente aumento do número de casos nas pessoas com 30 anos e mais, com realce para homens e mulheres entre 35 e 39 anos e entre 40 e 49 anos. A proporção de 
casos em indivíduos do sexo masculino de 40 a 49 anos de 1980 a 1990 era de $16,4 \%$ e, em 1995, de 17,7\%. Em 1999, ela aumentou para 20,1\% e em 2002 já correspondia a $24,9 \%$ do total. Na população feminina, a proporção nessa faixa etária passou de 10,8\%, de 1980 a 1990, para 21,7\% em 2002.

As desigualdades socioeconômicas que assolam o país também influenciam a dinâmica da aids. Nesse sentido observa-se aumento da incidência de casos na população de menor nível socioeconômico (Parker, 1994; Buchalla, 1995; MS, 1998, 2000, 2002a; Bastos e Szwarcwald, 2000; Parker e Camargo Júnior, 2000). Em 1996, cerca de 70,0\% dos casos de indivíduos do sexo masculino tinham nível de escolaridade equivalente ao " $1{ }^{\circ}$ grau" (ensino fundamental segundo a terminologia da nova Lei de Diretrizes e Bases da Educação). Para as mulheres, as proporções no grupo de menor grau de escolaridade já ultrapassavam os $70 \%$ desde o final da década de 80 (Fonseca e col., 2000).

Os homens de maior escolaridade ainda estão expostos a um risco superior àquele observado nos indivíduos de menor escolaridade, com exceção daqueles que residem na região Sudeste, onde a epidemia é a mais antiga do país, e na região Centro-Oeste, onde os dois grupos apresentam riscos comparáveis. No Sudeste e no Centro-Oeste do país, as mulheres encontram-se mais expostas quanto menor o grau de instrução. Na região Nordeste, as mulheres mais instruídas estão mais expostas e, nas regiões Norte e Sul, o risco entre os grupos é semelhante (Fonseca e col., 2000).

A sobrevida mediana das pessoas maiores de 12 anos com aids, no período de 1982 a 1989, era de 5,1 meses - cerca de 50\% morriam 6 meses após o diagnóstico da primeira infecção oportunista. Em 1995, as pessoas passaram a viver 16 meses e, para aqueles que foram diagnosticados em 1996, a sobrevida aumentou para cerca de 58 meses (Marins e col., 2002).

A descoberta dos anti-retrovirais e, mais tarde, a garantia de acesso ao tratamento de alta eficácia contribuíram sobremaneira para a redução da letalidade; todavia, o impacto positivo do direito conquistado é distinto para homens e mulheres (PANOS, 1993; Parker e Galvão, 1996; Diniz e Villela, 1999; Bastos, 2001; ECI, 2001; MS, 2002a, 2002b): em todas as regiões do país houve queda nos coeficientes de mortalidade por aids entre os homens, notadamente nas regiões Sudeste, Centro- 
Oeste e Nordeste; entre as mulheres, essa diminuição foi bem menor e não aconteceu em todas as regiões (MS, 2002a).

\subsubsection{A face paulista da epidemia}

Desde os primórdios da epidemia, o estado de São Paulo concentra o maior número de casos registrados no país: 108.175 casos $-45,5 \%$ do total acumulado. A capital paulista é o município que apresenta o maior número absoluto de notificações - 47.410 casos - que corresponde a $20,0 \%$ do total nacional de casos. Outro município importante na epidemia paulista é Santos, a qual ocupa a $6^{\mathrm{a}}$ posição em um universo de 100 municípios com os maiores números de casos notificados no país e detém $1,6 \%$ do total nacional acumulado (MS, 2002a).

A epidemia cresceu rapidamente no estado atingindo o pico máximo de incidência entre 1995 e 1996, para os homens, e apresentando tendência ascendente para mulheres até 1998. Na população masculina, o coeficiente de incidência (CI) foi de 44,64 por 100 mil habitantes em 1995; 44,76 em 1996 e 27,66 em 2000, na feminina variou de 5,05 por 100 mil habitantes em 1990 para 20,15 em 1998, sendo reduzido para 14,40 no ano 2000. Em conseqüência do aumento do número de casos registrados entre mulheres, houve brutal diminuição na razão por sexo: em 1984, a razão era de 27 notificações em homens para 1 em mulheres; em 1990, ela diminuiu para 5,5:1, chegando a 2:1 em 1997. Até 2001, aparentemente, a razão de sexo manteve-se em 2:1 (Santos, 2002).

No início, as principais subcategorias sexuais de exposição ao vírus eram "homo" e "bissexual". Até 1987, elas representavam mais da metade dos casos notificados entre os homens, todavia, a partir de 1986 o uso de drogas injetáveis começa a despontar como via importante de transmissão na população masculina: em 1988, essa via representou mais de 20,0\% dos casos, chegando a 34,9\% em 1993. A categoria "heterossexual", utilizada restritamente pela equipe de vigilância epidemiológica da SES-SP (empregada somente para aqueles que não relatam risco de exposição sangüínea e que referem ausência de práticas "bissexuais"), tem-se mostrado de crescente importância: em 1984 correspondeu a apenas 1,3\% das notificações, aumentando para 10,5\% em 1990; entretanto, representou 19,4\% e $30,5 \%$ do total de registros feitos no período de 1994 a 1995 e 2001, respectivamente (Santos, 2002). 
Entre as mulheres, a principal via de transmissão sempre foi a sexual subcategoria "heterossexual" -; porém, o uso de drogas injetáveis também teve grande importância na epidemia feminina: em 1987 e 1988, mais da metade dos casos foram incluídos na categoria UDI. Nos anos seguintes, a participação dessa categoria diminuiu passando de 48,7\% em 1989 a 34,2\% em 1992; 17,1\% em 1995 e $7,5 \%$ em 2001.

Ao mesmo tempo em que diminuía a proporção de casos em mulheres na categoria UDI, aumentava sua participação na categoria "heterossexual", logo, a importância do uso de drogas na disseminação do HIV entre as mulheres é marcante, seja pela via sanguínea ou pela via sexual (parceria sexual com usuário) - até dezembro de 2001, 31,7\% do total de casos notificados em mulheres eram atribuídos à parceria sexual com UDI (Santos, 2002).

$\mathrm{O}$ aumento do número de casos na população feminina traz, como conseqüência, o aumento dos casos em crianças, infectadas durante a gravidez, parto ou aleitamento materno (transmissão vertical ou materno-infantil). Com a introdução dos anti-retrovirais, houve diminuição nas taxas nacionais de transmissão vertical e, a partir de 1997, já foi possível verificar redução no número de casos entre menores de 5 anos - cobertura pré-natal (MS, 2002b). Entre os menores de 13 anos, mais de $80,0 \%$ dos casos ocorreram por essa via de transmissão, no estado de São Paulo e no Brasil (Santos, 2002; MS, 2002a).

Em relação à idade, na população masculina residente no estado de São Paulo ainda são mais freqüentes os casos notificados em indivíduos de 30 a 39 anos. Em 1996, por exemplo, o coeficiente de incidência (CI) nessa faixa etária foi de 121,82 por 100 mil. Também são freqüentes os casos em homens de 20 a 29 anos. O aumento da incidência na faixa etária de 40 a 49 anos é notável, passando de 14,29 por 100 mil em 1987 para 63,91 em 1998 (Santos, 2002) e mostra-se em concordância com os dados apresentados pelo Ministério da Saúde.

Para as mulheres, até 1993 as notificações eram mais freqüentes na faixa de 20 a 29 anos; contudo, a partir de 1994, o CI na faixa de 30 a 39 anos cresceu acentuadamente, passando de 26,44 por 100 mil para 48,65 por 100 mil em 1998; em contraposição, o CI para mulheres de 20 a 29 anos foi de 25,61 em 1994 e 36,99 por 
100 mil em 1998. Nas demais faixas de idade, os casos têm-se apresentado na mesma proporção, desde o início da epidemia (Santos, 2002).

Nos primeiros anos da epidemia predominavam, dentre os casos masculinos, os indivíduos com nível superior de ensino; mas, a partir dos anos 90, a proporção de homens com escolaridade igual ou inferior ao ensino fundamental tem aumentado, coincidindo com o aumento da proporção dos usuários de drogas injetáveis. Para as mulheres, sempre predominou a baixa escolaridade, com exceção do ano de 1984, em que, dos 2 casos notificados, 1 referia o $1^{\circ}$ grau e o outro o $2^{\circ}$ grau. Nos anos seguintes, a proporção de mulheres com escolaridade igual ou inferior ao $1^{\circ}$ grau correspondeu a mais de $80 \%$. As mulheres com nível superior de ensino representam cerca de $4 \%$ do total acumulado (Santos, 2002).

Sobre a evolução da mortalidade por aids no estado é importante ressaltar a existência de dois momentos: antes e depois de 1995. Até esse ano, quando a mortalidade atinge o ponto máximo, a tendência era crescente. A partir de então, inicia-se um processo de queda, com intensidade maior em 1997 e 1998 . A tendência descrita na população feminina acompanha aquela definida pela masculina, mas em patamar inferior (Waldvogel e Morais, 2002a, 2002b). Segundo as autoras, desde 1990 os municípios de São Paulo e Santos vêm apresentando as maiores proporções de óbitos por aids na população total e níveis de mortalidade superiores à média estadual, tanto para homens quanto para mulheres.

Em todo o estado tem sido verificada uma importante concentração de mortes entre pessoas de 20 a 54 anos. Entretanto, de 1990 a 2000, o padrão de mortalidade por aids, segundo sexo e idade, foi distinto: na população masculina com até 30 anos foi verificada a redução nas taxas de mortalidade e de incidência, o mesmo não ocorreu na população feminina, pelo contrário, nessa faixa etária foi observada a menor desaceleração na incidência e mortalidade. Em 1990, as mulheres de 20 a 29 anos apresentaram as maiores taxas de mortalidade e, em 2000, foram mais afetadas as mulheres de 30 a 39 anos; comportamento semelhante foi observado para a população masculina (Waldvogel e Morais, 2002a, 2002b). De acordo com Santo e col. (2000), em 1998, a idade média ao morrer entre as mulheres residentes no estado de São Paulo foi estatisticamente menor que a dos homens. 
Apesar do quadro otimista em relação à evolução da mortalidade por aids, o arrefecimento da velocidade de queda dos óbitos, o aumento das taxas entre pessoas de 35 anos e mais e o aumento do número absoluto de casos notificados entre mulheres são fatos que devem ser considerados no planejamento de ações (Santos, 2002; Waldvogel e Morais, 2002a, 2002b).

\subsection{Na Roda dos Expostos: as Mulheres e a Aids}

Diferente da epidemia disseminada pela África sub-saariana que, desde os momentos iniciais, atingiu duramente as mulheres, a epidemia brasileira, nos primeiros anos, afetou, desproporcionalmente os homens. No entanto, o tempo e as desvantagens sociais e de gênero contribuíram, de forma voraz, para a integração das mulheres ao cenário da aids.

A epidemia feminizou-se primeiramente porque, do ponto de vista biológico, as mulheres estão mais expostas à infecção pelo HIV. Durante o ato sexual, a superfície da mucosa vaginal fica exposta ao sêmen (líquido com altas concentrações do vírus) e, principalmente, na presença de outras infecções sexualmente transmissíveis (IST), ocorre aumento no número de células-alvo (linfócitos $\mathrm{T}$ e macrófagos), facilmente infectáveis (Wasserheit, 1992; Minkoff e col., 1995; Dallabetta e col., 1997). Esses riscos ampliados de infecção acentuam-se em mulheres jovens, porque a imaturidade do aparelho genital determina uma fragilidade adicional (Minkoff e col., 1995; UNAIDS, 2002a, 2002b).

As coortes etárias mais jovens também se encontram sob risco ampliado pelo fato de que, comumente, têm relações sexuais desprotegidas com homens mais velhos e que apresentam maior probabilidade de infecção por HIV e outras IST (Bastos, 2001; UNAIDS, 2002a, 2002b; OPAS, 2002).

Outra especificidade destacada por Michelle Long e col. (citado por Bastos, 2001) é a de que as mulheres recém-infectadas abrigam em seu organismo diversas quase-espécies do HIV-1. Essa heterogeneidade virótica dificulta a reação do sistema imunológico à infecção e facilita a emergência de variantes mais patogênicas e resistentes às diferentes terapêuticas. Independentemente dessa particularidade, cabe ressaltar que, há pouco tempo, mulheres infectadas passaram a ser incluídas em pesquisas clínicas sobre anti-retrovirais e outros medicamentos (OPAS, 2002), o que 
restringe as possibilidades de compreensão e intervenção na relação parasitahospedeiro.

No contexto das interações sociais, homens e mulheres estão vulneráveis à infecção pelo HIV e ao adoecimento por aids devido a determinações históricoculturais, sobretudo no que diz respeito às noções de gênero e sujeito por eles apreendidas.

O termo gênero foi inicialmente utilizado por feministas norte-americanas para introduzir uma noção relacional no vocabulário analítico. O uso do conceito, segundo elas, permitiria descobrir a amplitude dos papéis sexuais e do simbolismo sexual nas várias sociedades e épocas; permitiria identificar o sentido e o funcionamento da ordem social e, mais do que isso, a incorporação da categoria gênero ao escopo analítico dos estudos e pesquisas possibilitaria dar novos rumos à história das relações sociais (Scott, 1995). Embora tivessem aspirações ousadas, as teorizações feministas sobre gênero, até bem pouco tempo, utilizavam formulações antigas que propunham explicações causais universais e, por conseguinte, reduziam o sentido da complexidade e impediam o engajamento feminista na elaboração de análises que levariam à mudança sócio-histórica na realidade de homens e mulheres.

Para Scott (1995), gênero é um elemento constitutivo de relações sociais baseado nas diferenças percebidas entre os sexos - e uma forma primeira de significar as relações de poder. Segundo a autora, a propriedade constitutiva do conceito está representada pela interação contínua, mas não simultânea, de 4 subelementos: 1. os símbolos culturalmente disponíveis que evocam representações múltiplas - freqüentemente contraditórias; 2. os conceitos normativos que colocam em evidência interpretações do sentido dos símbolos e que tentam limitar e conter suas possibilidades metafóricas; 3 . a conveniência do termo para a análise e interpretação das sociedades modernas, dos sistemas políticos, de parentesco, do mercado de trabalho e da educação; 4. a identidade subjetiva relacionada com as organizações sociais e representações culturais historicamente situadas a partir dessa perspectiva.

Ainda citando Scott (1995), o conceito de gênero estrutura a percepção e a organização da vida social. Na medida em que a distribuição de poder é definida a 
partir de suas referências - controle e acesso diferencial aos recursos materiais e simbólicos -, o gênero está implicado na concepção e na construção do poder em si.

\subsubsection{Relações de gênero(s), exercício da sexualidade e aids}

Em virtude das inúmeras interpretações sobre as diferenças entre os corpos, as sexualidades são entrepostos favoráveis à luta contra aids. Em grande medida, a masculinidade heterossexual é uma construção trabalhosa e frágil, pois dependente, cotidianamente, da legitimação por parte de uma mulher. Essa dependência é apresentada por Guerriero (2001) como um dos fatores que contribuem para a vulnerabilidade masculina ao HIV/AIDS.

O processo educativo dos homens não estimula o contato com o seu corpo, com suas emoções e reações, pelo contrário, durante toda a vida os meninos e os homens são motivados a controlar as emoções, os gestos e o corpo; em não agindo da maneira esperada, eles podem deixar de ser considerados "homens de verdade". Assim, embora reivindiquem uma nova representação masculina, a maioria internaliza a "regra social" da sexualidade instintiva e sem limites; exerce maior poder em suas relações com mulheres e deixa de se proteger da infecção pelo HIV já que "homem, que é homem não chora e nem fica doente" (Villela, 1997; Mota, 1998; Guerriero, 2001; OPAS, 2002).

No imaginário coletivo, a aids é apresentada como “doença dos outros", "doença da rua" ou "doença dos solteiros". Em razão dessa leitura, os homens com parceria fixa não são motivados a usar preservativo, salvo como contraceptivo - nas relações com a parceira estável e nas extraconjugais (BENFAM, 1999; Mota, 1998; Vieira e col., 2000; Silva, 2002; Almeida, 2002; Guerriero e col., 2002; Pinho e col., 2002).

Os entraves colocados para a negociação do sexo protegido, independentemente do grau de instrução, poder aquisitivo ou independência financeira da mulher, revelam a opressão feminina, a falta de expectativas, de aspirações e de demandas das mulheres (Villela, 1996; Guimarães, 1996; Barbosa, 1999), mas não deixam de revelar também o estatuto atribuído ao(s) seu(s) parceiro(s). A estabilidade do vínculo é interpretada como um passaporte seguro para a não contaminação tanto para os homens como para as mulheres (Giami, 1998; Vieira e col., 2000; Almeida, 2002). 
As normas e valores sociais incutidos nos corpos e nas mentes humanas desencadeiam os processos de vulnerabilização. Em consonância com as "regras sociais", as mulheres têm menos controle das cenas e cenários sexuais, ou seja, exercem menos controle sobre as circunstâncias da relação sexual e as práticas protegidas. Nas raras oportunidades de discussão sobre essas e outras características da relação, a dependência econômica e a falta de argumentos plausíveis com seu mundo amoroso-reprodutivo reforçam suas vulnerabilidades e, assim, do número elevado de casos entre pessoas de sexo masculino deriva o aumento crescente do número de casos em mulheres, com destaque para aquelas que recebem o rótulo de "mulheres comuns" - monogâmicas, com parceiros estáveis e, em sua maioria, únicos (Santos, 1994, 1996; Barbosa e Villela, 1996; Guimarães, 1996; Villela, 1996; Santos e Munhoz, 1996; UNAIDS, 1998, 2000, 2002a, 2002b; Barbosa, 1999; Paiva, 1999; OPAS, 2002).

\subsubsection{Vidas positivas}

Entrevistando mulheres soropositivas atendidas em um serviço de ginecologia e obstetrícia da cidade de Porto Alegre, Knauth (1999) pôde observar que as entrevistadas ressaltavam a existência de dois modelos ou padrões de contaminação: um voluntário, derivado de práticas e comportamentos irresponsáveis e condenáveis; e outro involuntário, que se concretiza no desempenho de suas funções sociais de esposa (indulgente quanto à conduta do marido/companheiro) e que se dá em conseqüência da natureza masculina indomável. Em virtude dos valores morais que hierarquizam as vidas e as experiências vividas, o segundo padrão é comumente legitimado. Reflexões semelhantes já haviam sido apresentadas por Santos (1994, 1996), Santos e Munhoz (1996), Guimarães (1996).

Outro predicado social que contribui para a vulnerabilidade das mulheres ao adoecimento por aids é o acesso restrito aos serviços de saúde e às informações úteis e precisas para melhoria de sua qualidade de vida (Gollub, 1999; OPAS, 2002). Tal restrição deriva principalmente de sua responsabilidade, quase absoluta, pelo cuidado com a família, com os doentes, com os filhos, com o marido, com os idosos... Ao se dedicar ao cuidado com os outros, elas tendem a conceber o cuidado com a própria saúde como uma questão de ocasião ou oportunidade, imprimem menos atenção às mudanças em seu corpo ou mesmo aos sinais e sintomas de adoecimento. 
Operacionalmente as mulheres têm menores possibilidades de diagnóstico precoce. Entretanto, em consonância com a propriedade manipuladora do processo ideológico, elas negam suas possibilidades de risco, submetem-se à fatalidade e postergam o autocuidado, fatores que contribuem fortemente para a infecção e, no caso das soropositivas, para a aquisição de novas cargas de vírus (reinfecção) e para o adoecimento por aids (Santos, 1994; Santos e Munhoz, 1996; Barbosa e Villela, 1996; Diniz e Villela, 1999, Knauth, 1999; MS, 2002b).

\subsection{Vulnerabilidade: um Quadro Teórico-conceitual}

\subsubsection{A "emergência" do termo vulnerabilidade no campo da aids}

A complexidade do universo da aids (e do universo das vidas humanas que se interceptam durante a história) não permitia uma explicação causal stricto sensu e, em busca de um instrumento facilitador de interpretações, leituras e releituras da realidade, são fortalecidas as discussões sobre vulnerabilidade no âmbito da Coalizão Global de Políticas Públicas contra a Aids.

Liderados por Jonathan Mann, o grupo de epidemiologistas e operadores do direito ligados à Escola de Saúde Pública da Universidade de Harvard dispôs-se a arrolar informações e subsídios não restritos ao manejo estatístico de dados clínicos e epidemiológicos, expandindo o arsenal de saberes necessários para a resposta à pandemia no campo das ciências humanas, econômicas e políticas. A partir da publicação do livro Aids in the World em 1992, a expressão vulnerabilidade penetra mais amplamente o campo da saúde pública mundial.

No Brasil, o conceito vem ganhando feições particulares e imprimindo transformações marcantes nos estudos, pesquisas e ações e políticas para o controle da epidemia. 


\subsubsection{Da noção de risco à noção de vulnerabilidade}

No período da descoberta da entidade clínica aids, a terminologia fator de risco $^{2}$ foi emprestada aos grupos sociais de onde emergiam os primeiros casos $\mathrm{HSH}$, hemofílicos, UDIs e profissionais do sexo.

Os detentores dessas "alegorias" foram destituídos de sua humanidade, incluídos nos grupos de risco e apresentados às sociedades como os únicos susceptíveis à doença e, por conseguinte, potencialmente perigosos. Como não poderia ser diferente, essa época foi representada por resultados técnicos restritos e pela (re)produção, em grande escala, de estigmas e preconceitos (Mann e col., 1993, 1996; Ayres e col., 1999).

Ainda na primeira metade dos anos 90 , a idéia de grupo de risco passou a ser combatida, nomeadamente, pelo movimento gay organizado. Em substituição surge a idéia de comportamento de risco que se propõe a identificar quais as características individuais capazes de maximizar a susceptibilidade de indivíduos.

Embora mais avançada e menos rotuladora, a idéia de comportamento de risco também apresentava limitações: centrada na responsabilidade e proteção individuais, a noção de comportamento de risco desconsiderava a construção sociocultural do risco. Estava nítido que as eventuais falhas na prevenção derivavam mais da indisponibilidade de recursos materiais e simbólicos que da falta de vontade individual e informação; e que as transformações só poderiam ser vividas por aqueles que ampliassem seu repertório de direitos e que tivessem habilidade para elaborar e sustentar estratégias protetoras.

Estava estabelecida a importância de um novo recurso hermenêutico, capaz de universalizar o compromisso de prevenção e assistência, partindo de particularidades, operacionalmente úteis (Mann e col., 1993, 1996; Ayres e col., 1999, 2003).

\footnotetext{
${ }^{2} \mathrm{O}$ conceito de risco na epidemiologia moderna é definido como a chance probabilística de susceptibilidade, atribuível a qualquer indivíduo, de grupos populacionais particularizados, delimitados em virtude da exposição a agentes (agressores ou protetores) de interesse técnico ou científico. $\mathrm{Na}$ metodologia epidemiológica, os fatores de risco são associações regulares, estatisticamente significantes, entre características possivelmente implicadas na produção do agravo em estudo. São elementos probabilísticos disciplinadores do raciocínio causal (Ayres, 1997).
} 


\subsubsection{As dimensões da vulnerabilidade}

O objetivo de Mann e seus parceiros foi estabelecer um quadro de referência para a avaliação da vulnerabilidade à infecção por HIV e ao adoecimento por aids, que fornecesse critérios aplicáveis, desde um auto-exame individual até diagnósticos de programas e políticas em nível nacional. Com essa finalidade, o grupo define três planos interdependentes de análise: o componente individual, o componente social ou coletivo e o componente político ou programático.

No plano individual Mann e col. (1993) apresentaram várias definições para o conceito de vulnerabilidade:

- em termos absolutos, a expressão designaria os desprotegidos;

- em termos relativos estaria referindo-se àqueles que estão expostos a um risco maior do que a média;

- em termos epidemiológicos, o conceito estaria relacionado àqueles que apresentam maiores graus de exposição;

- em termos médicos designaria as pessoas incapazes de avaliar o nível e a qualidade da assistência médica;

- em termos operacionais, a expressão estaria relacionada àqueles que necessitam de maior grau de proteção e assistência;

- em termos de direitos humanos faria referência àqueles que estão expostos ao risco de discriminação ou tratamento injusto que desafiam os princípios de eqüidade e dignidade humana;

- em termos sociais estaria relacionada àqueles que não têm seus direitos efetivados ou que não têm acesso aos serviços sociais disponíveis;

- em termos econômicos faria referência aos incapazes de ter acesso a um nível satisfatório de assistência, devido a limitações financeiras;

- e em termos políticos diria respeito aos carentes de poder ou incapazes de conseguir representação total.

Segundo Ayres e col. $(1999,2003)$, a vulnerabilidade individual parte de três pressupostos: 1. todo indivíduo é, em algum grau, vulnerável à infecção pelo HIV e suas conseqüências, e essa vulnerabilidade pode variar ao longo do tempo, em conseqüência dos valores e recursos que lhe permitam ou não obter meios para se proteger; 2. os indivíduos infectados pelo HIV têm seu potencial de vulnerabilidade à 
morbidade, invalidez ou morte, variável em função inversa ao amparo social e assistencial de que dispõem; 3. as condições que afetam a vulnerabilidade individual são de ordem cognitiva (informação, consciência do problema e das formas de enfrentá-lo), comportamental (interesse e habilidade para transformar atitudes e ações a partir daqueles elementos cognitivos) e social (acesso a recursos e poder para adotar comportamentos protetores).

A dimensão programática da vulnerabilidade pode ser caracterizada pelos investimentos em ações e programas de informação e educação preventivas; a existência de serviços sociais e de saúde de fácil acesso, com alta qualidade, democraticamente delineados, periodicamente retro-alimentados e avaliados, além da adoção de mecanismos de não discriminação (Mann e col. 1993; Ayres e col., 1999).

A força do ambiente sociopolítico-econômico-cultural determina o sucesso dos programas e, em última instância, seu impacto sobre as pessoas. Diante disso o componente social da vulnerabilidade pode ser caracterizado: 1. pelo acesso que as pessoas e os grupos têm à (in)formação, aos serviços de saúde e a outros equipamentos sociais; 2. pelo nível de liberdade de expressão, representação e decisão que usufruem; 3. pelos indicadores de saúde, educação e renda; 4. pelo índice de desenvolvimento humano e pelo índice de pobreza e miséria. De acordo com Ayres e col. (1999), esse plano também considera as estruturas de governo; o repertório de crenças e valores relacionados à saúde e sexualidade; as relações de raça, etnia, gênero e geração.

\subsubsection{Horizontes práticos do conceito e demais aspectos agregados}

De forma sintética, a vulnerabilidade poderia ser definida, então, como o conjunto de aspectos individuais e coletivos relacionados ao grau e modo de exposição a uma dada situação e, de modo indissociável, ao maior ou menor acesso a recursos adequados para se proteger tanto do agravo quanto de suas conseqüências indesejáveis (Ayres, 2002).

Assim, os estudos de vulnerabilidade apresentam-se como recursos interpretativos da condição da pessoa humana nas sociedades modernas e seus horizontes práticos são de natureza político-cultural, pois desafiam seus condutores a denunciar os determinantes sociais do agravo; a "coletivizar" os compromissos políticos com o controle e enfrentamento do mesmo e a construir estratégias de intervenção que atinjam, produtivamente, esses determinantes (Ayres e col., 1999, 2003). 
Os autores Delor e Hubert (2000), ao afirmarem que, por intermédio da noção de vulnerabilidade, é possível caracterizar a interação de trajetórias individuais inseridas em amplos contextos sociais, políticos, econômicos e culturais, apontam a importância de realizar os estudos de vulnerabilidade associados aos estudos sobre construção de identidades. Para eles, durante os processos identitários, os mecanismos sociais de (re)produção das iniqüidades podem ser explicitados e explorados. Embora menos ousados que os estudiosos do campo da aids, Delor e Hubert, no artigo de revisão de literatura, apresentam a idéia de que tanto as redes sociais como as identidades estão diretamente relacionadas ao lugar ocupado pelos sujeitos na interação.

Sobre o estudo de redes complexas, Barbosa e col. (2000) e Guerriero (2001) destacam a importância das ligações relacionais entre os atores e os seus atributos. De acordo com a teoria das redes, as unidades têm influência umas sobre as outras e agem de forma dependente, por isso a atribuição de um valor primário às áreas de intersecção e secundário às particularidades daqueles cujas trajetórias se interceptam.

Se o conhecimento sobre vulnerabilidades busca a universalidade, as sinergias, os sincronismos e a síntese contra-argumentativa a partir de uma série de fatores objetivos, como postulam Ayres e col. (2003), é necessário que haja uma fonte de critérios objetivos, capaz de avaliar - de modo intersetorial e transdisciplinar - situações particulares, derivadas de conjunturas sociais mais profundas.

O repertório de direitos humanos e o sistema de referência no qual ele foi construído são os instrumentos mais coerentes, compreensíveis e práticos para analisar e intervir nos processos de vulnerabilização. Tal proposição está baseada no julgamento de que, a promoção e a proteção dos direitos humanos estão, intrinsecamente, relacionadas à promoção e proteção da saúde (Mann e col., 1996; 1999a, 1999b; Ayres e col., 1999, 2003; França Júnior e col., 2000).

A noção de que o conjunto de direitos humanos é composto por elementos solidários, criados para determinada finalidade e adaptáveis às mutações do meio onde atua, nos permite entender o cenário de elaboração e edição do seu repertório, para a proteção das liberdades individuais ou coletivas.

Tomando como referência as citações de Puchta e Kant feitas por Habermas (1997), o direito é o reconhecimento da liberdade que advém da igual medida aos 
homens, como sujeitos que detêm o poder da vontade e, ao mesmo tempo, a limitação da liberdade de cada um, à condição de sua concordância com a liberdade de todos. O sentido relacional que pressupõe a noção de direito é o mesmo que pressupõe a vulnerabilidade: uma vez respeitados, promovidos ou efetivados os direitos, as vulnerabilidades tendem a minimização ou erradicação.

Ao afirmar que as pessoas não são vulneráveis, elas estão vulneráveis, sempre a algo, em algum grau e forma, e em certo ponto do tempo e espaço, Ayres e col. (2003) explicitam, mais uma vez, a necessidade de um raciocínio sistemático anterior à ação. No tocante a essa "preparação", a caracterização das desigualdades sociais, geracionais, raciais, étnicas e de gênero e a análise crítica das situações discriminatórias desencadeadas por elas, são de suma importância. Com a finalidade de responder à necessidade premente de contextualização e para alcançar os objetivos do presente trabalho, os conceitos de raça e racismo são incorporados ao arcabouço teórico da vulnerabilidade.

\subsubsection{O conceito de raça}

De acordo com alguns autores, a idéia de raça não pode ser considerada universal por não prescindir de uma fundamentação objetiva, "natural" ou biológica (Goodman, 1995, 2000; Frota Pessoa, 1996; Santos RV, 1996). Para eles, a "fragilidade" terminológica e conceitual pode dificultar sua aplicação em estudos e pesquisas sobre saúde.

Aqueles que defendem o uso do conceito reiteram seu caráter mutável e afirmam que sua utilidade analítica está centrada exatamente na negação de uma fundamentação biológica e na confirmação de sua propriedade social e política plena (Fanon, 1983; Guimarães, 1995; Hasenbalg, 1996; Maggie,1996; López, 2000a, 2000b; Perea, 2000; Goodman, 2000; Delgado, 2000). De acordo com os autores, a utilização científica do conceito permite compreender e intervir em certas ações (inter)subjetivamente intencionadas e orientadas, suas implicações e desfechos.

Para Cashmore (2000), o conceito de raça poderia ser definido sob três prismas: 1. da classificação; 2. da significância; 3. da sinonímia. Do prisma da classificação, o termo designaria um grupo ou categoria de pessoas conectadas por uma origem comum; do prisma da significância, ele seria uma expressão, som ou imagem cujos significados, viabilizados somente por meio da aplicação de regras e 
códigos, seriam plásticos e mutantes; e, do prisma da sinonímia designaria um modo de entender e interpretar as diversidades por meio de marcadores inteligíveis.

Ao apresentar as possíveis definições de raça, o autor relata que o termo entrou para a língua inglesa no começo do século XVI e que, até o começo do século XIX, foi usado principalmente para referir-se a características comuns apresentadas em virtude de uma mesma ascendência. Desde o início do século XIX foram-lhes atribuídos vários outros sentidos; contudo, os componentes fenotípicos da ascendência atraíam a atenção das pessoas tão prontamente, que elas não eram capazes de perceber que a validade da raça como conceito dependia do seu emprego numa explicação. Ao ponderar sobre o caráter polissêmico do termo raça, o autor afirma que a diversidade de seus significados é influenciada pelas regras e códigos sociais de um determinado tempo histórico, pelos grupos sociais considerados e pelo espaço físico e simbólico que ocupam.

Para Habermas (1997), o controle da linguagem não se dá no modelo lógico/racional porque a linguagem é a (re)construção do mundo e não o seu resumo. Seguindo a lógica do autor, os sentidos e significados atribuídos ao objeto da comunicação o são, de acordo com o mundo que se quer construir, no momento que a construção é desejada e somente por aqueles que o querem.

No tocante ao discurso sobre raça, a linguagem tem a capacidade de reunir crenças e metáforas que o termo tradicionalmente vem incorporando e funciona ora como meio, ora como constituinte ativo dos processos de racialização dos grupos sociais (Guimarães, 1995).

Tanto a racialização como o racismo autorizam e naturalizam o tratamento diferencial de um grupo sobre o outro. Os atos de racialização existem, independentemente da aceitabilidade do termo raça (neo-racismo). Os neo-racistas usam da linguagem da vítima para confundi-la, para esvaziar o conteúdo de suas reivindicações e para manter a hierarquização social (Munanga, 1996).

Para descrever e analisar as desigualdades nas condições de vida e as especificidades dos processos de vulnerabilização experimentados por mulheres negras e não negras vivendo com HIV/AIDS em São Paulo, o termo raça será utilizado como sinônimo de grupo de pessoas socialmente unificadas em virtude de seus marcadores físicos. 


\subsubsection{A noção de racismo}

O racismo é um fenômeno ideológico ${ }^{3}$, uma doutrina, um dogma, um conjunto de crenças transmitidas pela linguagem ordinária, mantidas e alimentadas pela tradição (Guimarães,1995; Munanga, 1990; Cashmore, 2000; López, 2000, dentre outros).

A socialização cultural coloca os indivíduos e os grupos, em posições de competição por status e por recursos valorizados, isso ajuda a explicar como os atores sociais desenvolvem estratégias que têm por finalidade a obtenção de interesses específicos. Em sendo o racismo um fenômeno ideológico, sua dinâmica é revitalizada e mantida com a evolução das sociedades, das conjunturas históricas e dos interesses dos grupos. São esses predicados que fazem do racismo um "fabricante" e multiplicador de vulnerabilidades.

No Brasil, as hierarquias sociais são justificadas e racionalizadas de diferentes modos, todos eles (sem exceção) apelam à ordem "natural" de sua existência e apresentam-se como um traço constitutivo das relações sociais. Segundo Guimarães (1995), o sistema de hierarquização brasileiro (e da América Latina em geral) interliga raça e cor, classe social (ocupação, renda) e status (origem familiar, educação formal), sem, contudo, deixar de ser sustentado pela dicotomia racial branco versus preto que alicerçou a ordem escravocrata por três séculos e persiste ativa na atualidade, resistindo à urbanização, à industrialização, às mudanças de sistema e regimes políticos.

As sociedades latino-americanas e a sociedade brasileira, em especial, para além da ideologia, definem as posições sociais de seus membros de modo que lhes sejam garantidos direitos e privilégios em sua relação com o Estado ou com os demais grupos sociais. No plano das relações intersubjetivas, esses privilégios são

\footnotetext{
${ }^{3}$ De acordo com Ricoeur (1988), o fenômeno ideológico está ligado à necessidade, de um grupo social conferir-se uma imagem e representar-se. A ideologia se dá em virtude da distância que separa a memória social de um acontecimento repetido continuamente. Seu papel é difundir a conviç̧ão para além do círculo dos pais fundadores e perpetuar sua energia inicial para além do período de fervescência. É, ao mesmo tempo, aquilo que justifica e que compromete; é movida pelo desejo de demonstrar que o grupo que a professa tem razão de ser o que é. Logo, o fenômeno ideológico é sempre mais que um reflexo, na medida em que também é justificação e projeto. Para o autor, a ideologia é operatória e não temática porque sua definição está em seu próprio conteúdo. É a partir dele (o conteúdo da ideologia) que os sujeitos pensam e agem. Logo, a ideologia é um fenômeno insuperável da existência social, já que a realidade sempre possui uma constituição simbólica e comporta uma interpretação, em imagens e representações do próprio vínculo social.
} 
resguardados por etiquetas que têm, na aparência e na cor, as principais referências e marcos no espaço social (Munanga, 1990; Hasenbalg, 1996; Maggie, 1996; Guimarães, 1997; Bento, 1999).

O racismo nesses países apresenta dois pontos nevrálgicos: 1. o ideal do branqueamento ou embranquecimento e 2. a concepção desenvolvida por elites políticas sobre a harmonia e a tolerância raciais e sobre a ausência de preconceito e discriminação baseados nas raças - a propalada democracia racial.

De acordo com o ideal do branqueamento, vigente no final do século XIX, a solução harmoniosa para o problema racial dos países seria a desaparição gradual dos negros por meio de sua absorção pela população branca. No passado, como agora, os sistemas baseados no embranquecimento admitem o deslocamento social lento, ao longo do contínuo de cor, de modo que sejam mais aceitos aqueles que mais se aproximam da brancura, isto é, aos mestiços se oferece a ilusão de mobilidade e ascensão, enquanto aos pretos a única possibilidade oferecida é a de negação de sua auto-imagem (Fanon, 1983; Guimarães, 1995; Hasenbalg, 1996).

O mito da democracia racial firmou-se, progressivamente, como uma imposição política, e ainda hoje permanece eficiente dificultando contestações sobre uma suposta "ordem natural" de organização social. A operação da democracia racial brasileira é complexa e cruel desde a sua concepção: ao mesmo tempo em que impede a construção de uma identidade aglutinadora e fortalecedora entre os negros, ela seleciona e constrói diferenças atribuídas àqueles, de modo que os propósitos hierárquicos sejam atingidos e a "unidade" mantida (Duncan, 1986; Ribeiro, 1997; Rahier, 2001).

Como explicam Bento (1999) e Rossato e Gesser (2001), ao identificar-se como branco, o brasileiro reconhece a existência de um lugar socialmente desfavorável, ocupado pelo negro, mas desconsidera as conseqüências negativas das vantagens concretas e simbólicas acumuladas e mantidas no seio de seu grupo, como se elas fossem inexoráveis e incontestáveis.

\subsubsection{Desigualdades raciais no Brasil}

\section{Desenvolvimento humano}

De acordo com os dados censitários de $2000,45 \%$ da população brasileira são negros $-6,1 \%$ autoclassificados pretos e $38,9 \%$ autoclassificados pardos (Petruccelli, 
2002). Embora represente quase metade da população brasileira, em termos de desenvolvimento, o seguimento acumula desvantagens em todas as regiões do país.

Segundo Paixão (2002), entre 1997 e 1999, a população negra apresentou um Índice de Desenvolvimento Humano (IDH) médio-baixo ${ }^{4}$. Para a população branca, o índice vem aumentando a cada ano e, já em 1997 e 1998, pôde ser classificado como quase-alto. $\mathrm{O}$ autor ressalta que, quanto ao posicionamento dos $\mathrm{IDHs}^{5}$, é nas regiões mais desenvolvidas (Sul e Sudeste) que se encontram as maiores distâncias entre negros e brancos, como descrito na Tabela 1.

Tabela 1. Posição assumida pelo Índice de Desenvolvimento Humano brasileiro diante do ranking mundial, segundo cor e grande região. Brasil, 1997-1999.

\begin{tabular}{lcccccc}
\hline \multirow{2}{*}{ Grande Região } & \multicolumn{3}{c}{ Negros } & \multicolumn{3}{c}{ Brancos } \\
\cline { 2 - 7 } & $\mathbf{1 9 9 7}$ & $\mathbf{1 9 9 8}$ & $\mathbf{1 9 9 9}$ & $\mathbf{1 9 9 7}$ & $\mathbf{1 9 9 8}$ & $\mathbf{1 9 9 9}$ \\
\hline Norte $\left(^{*}\right)$ & 88 & 84 & 81 & 50 & 52 & 50 \\
Nordeste & 122 & 120 & 108 & 97 & 94 & 88 \\
Sudeste & 87 & 86 & 83 & 39 & 38 & 39 \\
Sul & 97 & 92 & 88 & 44 & 45 & 44 \\
Centro-Oeste & 82 & 79 & 73 & 42 & 41 & 41 \\
\hline Brasil & $\mathbf{1 0 5}$ & $\mathbf{1 0 6}$ & $\mathbf{1 0 1}$ & $\mathbf{4 6}$ & $\mathbf{4 6}$ & $\mathbf{4 6}$ \\
\hline
\end{tabular}

Nota: (*) Somente área urbana.

Fonte: Paixão (2002, p. 86).

A restrição das possibilidades de desenvolvimento é acentuada ao inserir gênero como categoria analítica. No ranking mundial do Índice de Desenvolvimento ajustado ao Gênero (IDG) apresentado no Relatório de Desenvolvimento Humano de 1999, o Brasil ocupou a $91^{\text {a }}$ posição com o IDG negro e a posição 48 com o IDG branco (Sant'Anna, 2001a, 2001b).

\footnotetext{
${ }^{4}$ Nos anos 80, para operacionalizar a avaliação do nível de progresso do desenvolvimento humano, o Programa das Nações Unidas para o Desenvolvimento (PNUD) elaborou o IDH, o qual mede a qualidade de vida de países, regiões ou agrupamentos populacionais específicos, combinando três níveis de indicadores (rendimento, educação e longevidade). O índice é calculado como a média das medidas transformadas e tem seus valores no intervalo de 0 a 1 (Januzzi, 2001). Em termos classificatórios, o PNUD define que os países cujos índices ficam abaixo de 0,500 apresentam IDH baixo, aqueles cujo índice fica entre 0,500 e 0,799 apresentam IDH médio e que aqueles que detém valores acima de 0,800 apresentam IDH elevado. Em seu artigo, Paixão destaca que o IDH médio foi desagregado com a finalidade de explicitar as diferenças contidas em seu interior. Assim, o grupo de cor que apresentou um IDH entre 0,500 e 0,599 foi classificado como IDH quase-baixo, entre 0,700 e 0,749 como IDH médio e entre 0,750 e 0,799 de IDH quase-alto.

${ }^{5} \mathrm{O}$ posicionamento do IDH no ranking mundial (composto por 163 países) é determinado com base nos valores descritos acima.
} 


\section{Emprego e renda}

No que diz respeito a emprego e renda, a Pesquisa Nacional de Domicílios (PNAD) de 1999 mostrou que a redução das taxas nacionais de desemprego são influenciadas pela cor da pele e o sexo daqueles que buscam (re)inserção no mercado de trabalho: para os homens brancos, a taxa foi de 7,5\%, para as mulheres brancas 12,5\%; para os homens pardos, 9,2\% , para mulheres pardas, 15,6\%; para os pretos, as taxas foram de $11,0 \%$ e $16,5 \%$ para homens e mulheres, respectivamente.

No estudo sobre desigualdades raciais no Brasil, o Instituto de Pesquisas Econômicas Aplicadas (IPEA) destaca que, em 1999, o índice de rendimento médio na ocupação principal de negros correspondeu a $48 \%$ do índice observado para a população branca (IPEA, 2001).

Nas pesquisas conduzidas pelo Instituto Sindical Interamericano pela Igualdade Racial (INSPIR) observou-se que os rendimentos de trabalhadores negros são, sistematicamente, inferiores aos rendimentos dos não negros, quaisquer que sejam as situações ou atributos considerados. Utilizando o salário dos homens brancos como referência, o INSPIR apresentou um quadro ainda mais aviltante que o descrito pelo IPEA, com destaque para a situação da mulher negra que, em algumas regiões metropolitanas apresenta rendimento médio correspondente a $28,3 \%$ do que recebe um homem branco (Tabela 2).

Tabela 2. Índice de Rendimento Médio Mensal ${ }^{(*)}$, segundo raça e sexo. Brasil, regiões metropolitanas, 1998.

\begin{tabular}{lcccc}
\hline \multirow{2}{*}{ Regiões Metropolitanas } & \multicolumn{4}{c}{ Índice de Rendimentos } \\
\cline { 2 - 5 } & $\begin{array}{c}\text { mulheres } \\
\text { negras }\end{array}$ & $\begin{array}{c}\text { homens } \\
\text { negros }\end{array}$ & $\begin{array}{c}\text { mulheres } \\
\text { não negras }\end{array}$ & $\begin{array}{c}\text { homens } \\
\text { não negros }\end{array}$ \\
\hline São Paulo & 33,6 & 50,6 & 62,5 & 100,0 \\
Salvador & 28,3 & 47,4 & 63,1 & 100,0 \\
Recife & 36,8 & 57,8 & 62,5 & 100,0 \\
Distrito Federal & 47,0 & 68,8 & 70,7 & 100,0 \\
Belo Horizonte & 36,1 & 75,9 & 62,1 & 100,0 \\
Porto alegre & 46,7 & 66,0 & 70,5 & 100,0 \\
\hline
\end{tabular}

Nota: $(*)$ rendimento médio mensal do homem não negro $=100 \%$ (valor de referência). Fonte: INSPIR (1999, p. 123).

Para além das disparidades nos rendimentos individuais de brancos e negros, o IPEA (2001) observou que, em 1999, a renda per capita média mensal nos 
domicílios com chefia negra correspondia a $42 \%$ dos valores observados nos domicílios com chefia branca.

\section{Educação}

Em 1999, a taxa de analfabetismo para população de 25 anos ou mais foi de $10,4 \%$ para brancos, $25,2 \%$ para pardos e $25,9 \%$ para pretos. Naquele ano, a escolaridade média da população adulta foi de 4,2 anos para os pretos; 4,4 anos para os pardos e 6,6 anos para os brancos (IPEA, 2001).

De acordo com Sant'Anna (2001b), a taxa de alfabetização para a população negra foi 13 pontos percentuais menor que para a população branca (78\% versus $90 \%)$ sendo o maior índice educacional observado entre os homens brancos $(0,887) \mathrm{e}$ o menor entre os homens negros $(0,753)$. As mulheres brancas tiveram o índice calculado em 0,877 e as negras em 0,773 .

\section{Saúde}

As desigualdades e iniqüidades em saúde têm antecedentes históricos, políticos, econômicos e culturais que interferem no estado de saúde dos indivíduos e dos coletivos, determinando a natureza e a magnitude das disparidades instaladas e toleradas nos diversos meios sociais.

É sabido que as doenças em geral disseminam-se de acordo com os "caminhos" abertos pela estrutura social, pelos valores e pelas culturas. O fato de os negros estarem expostos a um processo cumulativo de desvantagens sociais determina suas vulnerabilidades diante de uma série de agravos à saúde no Brasil e em outras partes do mundo (Muntaner e col., 1996; Herman, 1996; Barbosa, 1998; Pinto e col., 2000; Delgado, 2000; Olinto e Olinto, 2000; Cunha, 2001a; Guimarães CD, 2001; Oliveira, 2001; Lam, 2002; Cain e Kington, 2003; Krieger, 2003).

Da mesma forma que o racismo apresenta-se como um fenômeno ideológico, a luta por sua extinção também o é. A edificação e a utilização do conceito de raça em saúde estão justificadas pela necessidade de elaborar estratégias de superação das desigualdades evitáveis e consideradas injustas.

\section{Saúde reprodutiva}

No cenário brasileiro, desde o início da década de 90, pesquisadoras negras e não negras têm evidenciado diferenças raciais no campo da saúde sexual e reprodutiva. 
A Pesquisa Nacional de Demografia em Saúde (PNDS) de 1996 mostrou que as mulheres negras tinham duas vezes mais chance de ter o primeiro filho com idade igual ou inferior a 16 anos. Quando comparadas às brancas, elas tinham menos chances de contracepção e mais chances de estarem grávidas, ainda que não tivessem a intenção (Chacham, 2001).

Analisando as informações contidas na mesma base de dados - PNDS, 1996 a autora Perpétuo (2000) apontou as diferenças no cuidado oferecido a mulheres negras e brancas na área de saúde sexual e reprodutiva: a não realização de consultas ginecológicas completas ${ }^{6}$, a ausência de consultas de pré-natal ou o número de consultas abaixo do preconizado bem como o não oferecimento do exame ginecológico pós-parto estiveram estatisticamente associados à variável cor da pele.

A falta de acesso aos serviços e as orientações de boa qualidade; as condições ambientais adversas, as noções e os valores relacionados à saúde e à doença têm levado as mulheres negras a serem mais histerectomizadas que as brancas em decorrência de miomatoses (Souza, 1998, 2000, 2001; Oliveira 1999; Silva e col., 2002) $)^{7}$.

\footnotetext{
${ }^{6}$ A autora informa que, para mulheres com até 35 anos de idade, a consulta ginecológica completa deve incluir exame físico e coleta de material para a realização do exame de Papanicolaou. Para as mulheres com 35 anos e mais, a consulta é considerada completa ao incluir mamografia, além do exame físico e coleta de esfregaço vaginal.

${ }^{7}$ Os autores explicam que os miomas são tumores uterinos não invasivos - benignos - que podem ocorrer em $20 \%$ das mulheres entre a menarca e a menopausa. São considerados silenciosos, pois podem permanecer assintomáticos. Quando estão presentes, os sintomas mais comuns são hemorragias, dores pélvicas e alterações no peso corporal. O tratamento pode ser clínico - com acompanhamento e medicamentos - ou cirúrgico através de miomectomia, histerectomia ou embolização. A miomectomia é uma intervenção cirúrgica onde somente as massas tumorais são retiradas. Na histerectomia, o útero é retirado. Por ser profundamente agressivo e ter a capacidade de interromper a vida reprodutiva, o método é recomendado para os casos em que o tumor apresente tamanho igual ou superior a uma gestação de 12 semanas. A embolização consiste na diminuição da quantidade de sangue que irriga útero com conseqüente regressão do mioma.
} 


\section{Atendimento pré-natal e parto}

Das 3.025 mulheres que tiveram filho(s) nos 5 anos anteriores à realização da PNAD de 1996, as mulheres negras apresentaram menores probabilidades de realizar a primeira consulta em período igual ou inferior ao $4^{\circ}$ mês de gravidez e maiores probabilidades de não terem recebido assistência médica durante todo o período gravídico. A chance de pelo menos um dos filhos dessas mulheres negras ter nascido em casa foi 3,73 vezes a chance observada para as brancas (Perpétuo, 2000).

Um estudo realizado na cidade do Rio de Janeiro apontou que mais mulheres negras que brancas deixaram de ser examinadas adequadamente durante o pré-natal, deixaram de receber informações sobre os sinais do parto, alimentação durante a gravidez e importância do aleitamento materno nos primeiros seis meses de vida do bebê. As chances de as mulheres negras entrevistadas não terem sido anestesiadas no momento do parto foram de duas vezes a de mulheres brancas (Petry, 2002).

\section{Mortalidade feminina e infantil}

Ao descrever as diferenças no padrão de mortalidade infantil dos anos 60 e 80, Cunha $(1997,2001,2002)$ mostra que o poder de predição da variável raça na mortalidade infantil é uma evidência quase constante, mesmo controlando outros fatores de risco, e destaca a influência da escolaridade, ocupação e rendimentos da mãe no comportamento das taxas de mortalidade. Mais recentemente, Sant'Anna (2001b) ressaltou a manutenção das disparidades: em 1996, para as crianças negras, a taxa de mortalidade era de 62,3 por mil; para as crianças brancas, era de 37,3 por mil. Segundo a autora, os dados das PNADs mostravam que entre as crianças menores de 5 anos as discrepâncias eram ainda maiores: 76,1 por mil versus 45,7 por mil, para crianças negras e brancas, respectivamente.

No que diz respeito à mortalidade feminina, Cunha $(1997,2001 b)$ constata que no Brasil mulheres negras adultas com 25 anos apresentam mais chances que as brancas de morrer antes de completar os 75 anos.

\section{Mortalidade por causas diversas}

No Brasil, a esperança de vida da população negra é menor que a da população branca, especialmente para os homens negros (Sant'Anna, 2001b). No estado de São Paulo, a população negra tem maior risco de morrer por acidente vascular cerebral, septicemias, homicídios, diabetes, tuberculose, câncer de colo, 
câncer de próstata e aids - causas passíveis de serem evitadas com atenção médica adequada (Batista, 2002). Em seus estudos sobre racismo em saúde Barbosa (1998, 2001) constatou que, quando comparados aos brancos residentes no estado de São Paulo, os negros apresentam maior proporção de anos de vida perdidos e, para as mesmas patologias ou agravos, suas vidas são subtraídas mais cedo.

De acordo com os dados do Programa de Aprimoramento das Informações de Mortalidade no Município de São Paulo (PROAIM), em 1999 ocorreram 64.377 óbitos de residentes na cidade assim distribuídos segundo raça/cor: amarelos $-2,1 \%$; brancos $-67,4 \%$; indígenas $-0,1 \%$; pardos $-16,9 \%$; negros $-5,1 \%$; ignorados $8,4 \%$. Em todos os grupos de cor prevaleceram os óbitos do sexo masculino, mas entre os pardos a proporção foi maior. Na categoria pardos, 55\% das mortes ocorreram entre indivíduos com menos de 50 anos (morte precoce), entre os pretos a proporção de mortes precoces foi de $42 \%$, entre os indígenas $35 \%$, em contraposição, entre os brancos e amarelos, grande parte das mortes ocorreu no grupo com idade acima de 50 anos.

Comparando o perfil de mortalidade nos grupos de cor amarela e branca, a principal causa de morte foram as doenças isquêmicas do coração. Entre indígenas, pardos e pertos prevaleceram os homicídios; para pretos e pardos, também se destacaram as doenças infecciosas (tuberculose e aids) e os acidentes de trânsito. Entre as 10 principais causas de morte figuraram a cirrose hepática e o alcoolismo para pardos e pretos, e as doenças hipertensivas entre indígenas e pretos. A aids ocupou a quarta posição entre as causas de morte para os indígenas, a nona para os pardos e a oitava para os pretos (PROAIM, 2000). 


\section{AIDS E POPULAÇÃO NEGRA: A RELEVÂNCIA DA PESQUISA COM MULHERES}

As sociedades e sua modernidade determinam o futuro dos corpos e das mentes daqueles que as compõem (Basset, 2000) e, em razão disso, as noções de raça e racismo são intrínsecas às sociedades modernas.

Em todos os lugares do mundo onde as desigualdades raciais são naturalizadas, a epidemia da aids atinge de forma mais severa os grupos historicamente excluídos da riqueza social, bem como aqueles que são culturalmente discriminados. Nos Estados Unidos, por exemplo, 42\% das 362.827 pessoas que viviam com HIV até dezembro de 2001 eram negras (até dezembro de 1999, essa proporção era de $37,2 \%$ ).

De acordo com o CDC (2001) até dezembro de 2001 dos 807.075 casos reportados entre adultos e adolescentes, 57,0\% vieram a óbito. De 1996 a 1997, o número de mortes por aids naquele país diminuiu bruscamente e continuou a declinar até 2001 em todos os grupos raciais/étnicos, com exceção aos indígenas norteamericanos e nativos do Alasca. Além disso, embora o número absoluto de mortes tenha diminuído, a participação relativa da população negra entre aqueles que foram a óbito permaneceu maior que a dos brancos em todas as faixas etárias e, especialmente, entre as mulheres.

No Brasil há tempos o movimento de mulheres negras vem chamando atenção para a possibilidade de aumento de infecção na população negra, mormente, entre as mulheres (Roland, 1992; Pinho, 1998; Werneck, 2000, 2001).

Negros e brancos inserem-se de forma diferente nas redes sociais; contudo, os especialistas do campo da aids têm evitado considerar esse fato, anulando de forma sistemática e persistente as possibilidades de discussão sobre vulnerabilidades e raça, tanto nas pesquisas acadêmicas como nas análises oficiais dos dados da vigilância epidemiológica e atestados de óbito.

Cientes de sua responsabilidade social, alguns autores passaram a fazer referência à variável raça/cor como recurso imprescindível a uma análise mais criteriosa sobre os processos de vulnerabilização (Bastos e Szwarcwald, 2000; Parker e Camargo Júnior, 2000; Bastos, 2001; Ayres, 2002; Paiva, 2002; Ayres e col., 2003). Entretanto, o caráter tardio da ressonância pública do problema denuncia a 
distância assumida por esses empreendedores (e pela sociedade em geral) em relação aos "novos incluídos".

A primeira iniciativa de análise oficial dos números da aids, segundo raça/cor, foi relatada pelo Centro de Referência e Treinamento em DST-AIDS da Secretaria de Estado da Saúde - São Paulo, em documento oficial no ano de 2001 (PE-DST/AIDS, 2001). Os dados, apresentados em série histórica, deixaram evidentes as tendências crescentes de aumento no número de negros inscritos no serviço e de aumento no percentual de óbitos entre os mesmos ${ }^{8}$.

As populações negras vivem, crescem, envelhecem, adoecem e morrem diferentemente dos não negros no Brasil e em outros cantos do mundo (Muntaner, 1996; Sen, 2001; Lam, 2002; Willians e col., 2003; Murray, 2003). Em vista disso, é justo e coerente que estudiosos e pesquisadores brasileiros visualizem a importância analítica das categorias de raça/cor no campo da saúde e, mais especificamente, no campo da aids.

O dispositivo ideológico da omissão contribui para a perpetuação de ações discriminatórias, portanto, a disponibilidade de informações concretas e qualificadas sobre os diferentes grupos de cor possibilitará a elaboração de políticas públicas equânimes e a implementação de um modelo de atenção que contemple necessidades individuais e coletivas, respeite as diferenças e promova a igualdade.

\footnotetext{
${ }^{8}$ O levantamento foi realizado no Centro de Referência e Treinamento do Programa Estadual de DST/AIDS da Secretaria de Saúde do Estado de São Paulo, de 1980 a 2001. Nesse levantamento, a classificação de cor foi feita pelo profissional e não pelo usuário.
} 


\section{OBJETIVOS}

\subsection{Objetivo Geral}

A partir do recorte racial, compreender a vulnerabilidade de mulheres que vivem com HIV/AIDS à reinfecção e ao adoecimento no Estado de São Paulo.

\subsection{Objetivos Específicos}

a) Examinar as diferenças sociodemográficas e epidemiológicas existentes entre mulheres negras e não negras portadoras do HIV, matriculadas em três serviços públicos de referência do Estado de São Paulo.

b) Descrever e interpretar, segundo raça/cor, as interações estabelecidas entre as variáveis sociodemográficas e aquelas relacionadas ao teste e aos cuidados recebidos, à vida sexual após o diagnóstico, à qualidade do serviço de saúde onde se trata (acesso, acolhimento, relação com os profissionais) e aos cuidados com a saúde. 


\section{SUJEITOS, MATERIAL E MÉTODOS}

\subsection{Antecedentes: Programa Enhancing Care Initiative (ECI-Brasil)}

Os dados ora estudados foram obtidos em uma pesquisa multicêntrica coordenada pelo doutor José Ricardo Ayres, livre docente do Departamento de Medicina Preventiva da Faculdade de Medicina da Universidade de São Paulo. Realizada no Brasil, mais especificamente no estado de São Paulo, a pesquisa integra o programa multinacional Enhancing Care Initiative, cujo objetivo é contribuir para a melhora de qualidade do cuidado oferecido a homens, mulheres e crianças vivendo com o HIV/AIDS, em países em desenvolvimento.

A iniciativa, coordenada pelo Harvard AIDS Institute, em colaboração com o Programa Internacional de Saúde e Direitos Humanos do Centro François-Xavier Bagnoud para Saúde e Direitos Humanos e o Departamento de Populações e Saúde Internacional da Universidade de Harvard, nos Estados Unidos, conta com o apoio financeiro da Merck Company Foundation e vem sendo desenvolvida, desde 1998, no Brasil, Senegal, África do Sul, Tailândia e Porto Rico.

As equipes de trabalho são compostas de acordo com a realidade e necessidades locais, podendo contar com epidemiologistas, clínicos, economistas, pessoas vivendo com HIV/AIDS, operadores do direito, membros do governo e das universidades, cientistas políticos e especialistas em direitos humanos. Os grupos determinam suas próprias agendas e todos, sem exceção, buscam disseminar seus achados na forma de recomendações para a elaboração de políticas públicas integrais e equânimes, visando à promoção de ações e práticas mais inclusivas e efetivas, elaboração de artigos e outras publicações científicas que sirvam de referência para estudiosos e pesquisadores, gestores, profissionais de saúde e sociedade interessada.

No Brasil, a equipe multidisciplinar delineou dois estudos com o objetivo de analisar o rápido aumento das taxas de prevalência de infecção entre as mulheres dos municípios de São Paulo, Santos e São José do Rio Preto (com conseqüente aumento das possibilidades de transmissão vertical ou materno-infantil, durante a gestação, parto e amamentação) e propor mudanças na organização dos serviços de referência em DST/AIDS desses locais. 
O primeiro estudo examinou fatores que afetam a qualidade dos serviços de saúde pública oferecidos às mulheres vivendo com HIV. O segundo estudo, que também visava examinar fatores e obstáculos capazes de afetar a qualidade dos serviços de saúde, considerou a assistência oferecida durante a gravidez e o parto.

Os resultados obtidos possibilitaram concluir que os serviços de saúde pública existentes não respondem às necessidades desse grupo especialmente vulnerável, e apresentar recomendações aos elaboradores de políticas públicas para melhoria do cuidado (ECI, 2001).

\subsubsection{Delineamento da pesquisa multicêntrica}

O estudo é observacional, descritivo e de corte transversal.

\subsubsection{População acessível}

Mulheres portadoras do HIV, matriculadas no Centro de Referência e Treinamento do Programa Estadual de DST/AIDS (CRT-DST/AIDS-SP) da Secretaria de Estado da Saúde (SES-SP), Casa da Aids da Divisão de Moléstias Infecciosas e Parasitárias da Faculdade de Medicina da Universidade de São Paulo (CAIDS/FMUSP) e Centro de Referência em AIDS (CRAIDS) da Secretaria Municipal de Saúde de Santos e que tivessem consulta agendada com infectologista nos períodos de 13 de setembro a 20 de dezembro de 1999 ou de 15 de janeiro a 29 de fevereiro de 2000.

\subsubsection{Critérios de inclusão}

As mulheres potencialmente incluídas no estudo deveriam ter idade superior a 18 anos e capacidade de responder, coerentemente, às questões apresentadas.

\subsubsection{Cálculo da amostra}

Foi estimada uma amostra de 384 mulheres em cada serviço, aceitando-se uma porcentagem de, aproximadamente, $50 \%$ de um atendimento bom, com alfa de $5 \%$ e intervalo de confiança de 10\%. Foram convidadas para participar 1.130 mulheres, assim distribuídas: 363 mulheres no CRT-DST/AIDS, 423 na CAIDS/FMUSP e 344 em Santos no CRAIDS. Para selecionar a amostra, os períodos de atendimento foram divididos em subperíodos de 2 horas. Para cada subperíodo foram convidadas as duas primeiras mulheres com consultas agendadas (amostragem consecutiva cumulativa). Caso concordassem com a entrevista, as 
mulheres realizavam, com as entrevistadoras, uma leitura partilhada do termo de consentimento e o assinavam.

A amostra final envolveu 335 mulheres no CRT-DST/AIDS-SP (92,3\% das convidadas), 394 na CAIDS/FMUSP (93,2\% das convidadas) e 339 no CRAIDS (98,5\% das convidadas), conforme descrito na Tabela 3.

Tabela 3. Distribuição de freqüência e porcentagem de mulheres portadoras do HIV, por categoria de participação no estudo, segundo local de atendimento. São Paulo, 2000.

\begin{tabular}{lrrrr}
\hline \multirow{2}{*}{$\begin{array}{l}c \\
\text { Atend de }\end{array}$} & \multicolumn{2}{c}{ Recusas } & \multicolumn{2}{c}{ Entrevistadas } \\
\cline { 2 - 5 } & $\mathbf{N}^{\mathbf{o}}$ & $\mathbf{\%}$ & $\mathbf{N}^{\mathbf{0}}$ & $\mathbf{\%}$ \\
\hline CRT-DST/AIDS & 28 & 45,2 & 335 & 31,4 \\
CAIDS/FMUSP & 29 & 46,7 & 394 & 36,9 \\
CRAIDS & 5 & 8,1 & 339 & 31,7 \\
\hline Total & $\mathbf{6 2}$ & $\mathbf{1 0 0 , 0}$ & $\mathbf{1 . 0 6 8}$ & $\mathbf{1 0 0 , 0}$ \\
\hline
\end{tabular}

\subsubsection{Caracterização das recusas}

As 62 recusas $(5,5 \%$ do total de mulheres convidadas) foram justificadas, sobretudo, por problemas pessoais, por não desejar falar sobre sua vida $(33,8 \%)$ ou por falta de tempo $(35,5 \%)$. A distribuição das recusas segundo os serviços participantes foi: CAIDS/FMUSP, 29 recusas $(6,8 \%$ das convidadas atendidas no serviço), CRT-DST/AIDS-SP, $28(7,7 \%)$ e CRAIDS, 5 recusas $(1,5 \%$ das convidadas). A idade dessas mulheres variou de 35 a 38 anos. Esse dado deve ser visto com cuidado uma vez que o número é pequeno e que 15, das 62 recusas, não tiveram suas idades registradas. Não foi verificada associação entre idade da mulher e recusa em participar do estudo.

Não houve informação sobre a variável "renda" em 18 casos: 6 mulheres não souberam informar e 12 não o desejaram. Onze não tinham rendimento no momento em que o estudo foi realizado. Para aquelas que possuíam renda individual, esta variou de $\mathrm{R} \$ 610,00$ (entre as recusas da CAIDS/FMUSP) a $\mathrm{R} \$ 1.100,00$, entre as recusas do CRAIDS.

Em relação à escolaridade, a maior proporção de mulheres foi observada na faixa de 5 a 8 anos de escolaridade (30,2\% do total), seguidas pela faixa de 9 a 11 anos $(17,5 \%)$ e de 0 a 4 anos de freqüência escolar (14,3\%). Foi importante notar que $23,8 \%$ das recusas deixaram de responder a essa questão. 


\subsubsection{População sob estudo}

Mulheres voluntárias, atendidas no CRT-DST/AIDS, CAIDS/FMUSP e CRAIDS, nos períodos de 13 de setembro a 20 de dezembro de 1999 ou de 15 de janeiro a 29 de fevereiro de 2000 e que não tivessem participado da pré-testagem dos instrumentos de coleta de dados.

\subsubsection{Instrumentos para coleta de dados}

Foram desenvolvidos 3 questionários com o intuito de avaliar as condições de vulnerabilidade da mulher associadas ao cuidado à saúde. O primeiro questionário, com 84 perguntas, continha informações que caracterizavam a população estudada em relação a aspectos sociodemográficos (moradia, cor, escolarização, trabalho, renda, composição familiar); vida sexual e reprodutiva (parceiros, história de violência, aspectos relacionados à contaminação pelo HIV, uso de contraceptivos); aspectos relacionados à percepção de risco de contaminação pelo HIV (tempo que sabia ser soropositiva, motivo pelo qual fez o teste, como achava que havia se contaminado, uso de drogas); cuidados recebidos no serviço (aconselhamento pré e pós-teste, apoio no momento de receber o resultado, informações recebidas em relação à condição de portadora, necessidades e procura de apoio); acesso e acolhimento no serviço de saúde (tipo de assistência, forma de acesso, tempo para chegar ao serviço de saúde, tempo de matrícula, tipo de atendimento, forma de atendimento, atenção do profissional, situações vividas no momento dos atendimentos); e relação com o serviço e cuidado com a saúde (freqüência ao serviço, faltas, acompanhamento pelos profissionais de saúde, exames realizados, conhecimento sobre os exames, medicamento e adesão ao tratamento, dificuldades encontradas, apoio encontrado nos serviços, identificação de necessidades que deviam ser supridas pelos serviços).

O segundo questionário, respondido exclusivamente por aquelas que tiveram filhos em 1998, era composto por 33 perguntas sobre pré-natal, parto, tratamento durante a gestação, cuidados com o recém-nascido, orientação sobre prevenção da transmissão vertical através do uso de medicamentos e da não amamentação.

O terceiro questionário, destinado apenas àquelas que receberam assistência pré-natal, continha 24 perguntas sobre cuidados específicos no período de gestação (local de realização do pré-natal, mês em que o acompanhamento foi iniciado, 
número de consultas, exames realizados), atendimento recebido (tipo de consulta realizada, informações sobre os exames solicitados), orientações sobre risco de transmissão vertical, tempo de espera pelos resultados, oferta de medicamentos e orientações sobre efeitos colaterais, orientação e indicação sobre maternidade(s) de referência.

Os instrumentos foram pré-testados e as estratégias de abordagem e coleta de dados revisadas no período de junho a julho de 1999. Foram realizadas 24 entrevistas e sua distribuição está apresentada na Tabela 4.

Tabela 4. Distribuição da freqüência e porcentagem de mulheres soropositivas na fase de pré-testagem de instrumentos, segundo local de atendimento.

São Paulo, 1999.

\begin{tabular}{lrr}
\hline Local de Atendimento & $\mathbf{N}^{\mathbf{0}}$ & $\mathbf{\%}$ \\
\hline CRT-DST/AIDS & 4 & 16,7 \\
CAIDS/FMUSP & 12 & 50,0 \\
CRAIDS & 8 & 33,3 \\
\hline Total & $\mathbf{2 4}$ & $\mathbf{1 0 0 , 0}$ \\
\hline
\end{tabular}

\subsubsection{Aspectos éticos}

O projeto foi submetido à Comissão de Ética para a Análise de Projetos de Pesquisa do Hospital das Clínicas da Faculdade de Medicina da Universidade de São Paulo e aprovado por ela (Anexo I).

O termo de consentimento pós-informação (Anexo II) foi elaborado de acordo com as regras estabelecidas pela Resolução n 196, de 10 de outubro de 1996, do Conselho Nacional de Saúde (CNS). No documento foram oferecidas informações sobre os objetivos da pesquisa, os procedimentos que seriam utilizados, os riscos, desconfortos e benefícios para os participantes, o sigilo e a possibilidade de abandonar a entrevista a qualquer momento, sem prejuízo para a continuidade de seu cuidado e tratamento. As pessoas que consentiram em participar, receberam uma via do documento assinada pela entrevistadora.

As necessidades e demandas detectadas durante a pesquisa foram encaminhadas para as equipes responsáveis pelos serviços.

\subsection{Desenvolvimento do Presente Trabalho}

Com a finalidade de identificar e compreender os diferenciais raciais no processo de vulnerabilização das mulheres ao adoecimento por aids, os 
procedimentos apresentados a seguir foram adotados para uma releitura dos dados obtidos na pesquisa descrita no item 5.1 após aprovação do Comitê de Ética em Pesquisa da Faculdade de Saúde Pública da Universidade de São Paulo (Anexo III).

\subsubsection{Variáveis de estudo}

No presente estudo, algumas das informações coletadas com o auxílio do primeiro questionário (Anexo IV) foram analisadas segundo o critério raça/cor. É importante ressaltar que a informação sobre esse critério foi auto-referida e que as categorias utilizadas seguiram o padrão IBGE de classificação: preto, pardo, amarelo, indígena e branco. A união de mulheres autoclassificadas como pretas e pardas deu origem ao grupo de mulheres negras e a soma de mulheres autoclassificadas como brancas, amarelas e indígenas, originou o grupo de mulheres não negras. Para a análise foram válidos somente os casos daquelas que souberam ou quiseram informar. O tratamento dado a cada variável é apresentado nos itens a seguir.

\subsubsection{Variáveis sociodemográficas}

- Faixa etária. Agrupada em 5 classes: 18 a 25 anos, 26 a 35 anos, 36 a 45 anos, 46 a 55 anos, 56 anos e mais.

- Nível de escolaridade. Categorizada em: nenhum (inclusive aqueles que nunca foram à escola mas sabem ler e escrever); ensino fundamental $1\left(1^{\mathrm{a}} \mathrm{a}\right.$ $4^{\mathrm{a}}$ séries); ensino fundamental $2\left(5^{\mathrm{a}}\right.$ a $8^{\mathrm{a}}$ séries); ensino médio (in)completo; ensino superior (in)completo.

- Tipo de habitação. Categorizada em: casa de tijolos; apartamento; casa de madeira; casa de cômodos. Foram excluídas aquelas que moravam em casa de apoio ou na rua.

- Número de cômodos. Agrupado em 2 classes com intervalos de 3 cômodos e 1 classe aberta, categorizada em: 1 a 3 cômodos; 4 a 6 cômodos; 7 cômodos ou mais. Foram excluídas aquelas que não moravam em casa de tijolos, apartamento ou em casa de madeira.

- Condições de moradia. Para o estudo dessa variável foram válidos somente os casos daquelas que habitavam casa de tijolos, casa de madeira ou apartamento e que souberam ou quiseram dar informação referente ao número 
de cômodos, agrupados em 2 classes com intervalos de 3 cômodos e 1 classe aberta, categorizada em: 1 a 3 cômodos; 4 a 6 cômodos; 7 cômodos ou mais.

- Ocupação. Foram criadas 2 categorias (ativas e inativas) divididas em subcategorias. Na categoria ativa foram incluídas aquelas que relataram: emprego fixo (trabalho formal); bico, prostituição (trabalho informal); aquelas que se identificaram como autônomas-contribuintes; e as desempregadas. Foram consideradas inativas aquelas que relataram: ter parado de procurar emprego; as aposentadas ou dependentes de salário da previdência social; e as mulheres autoclassificadas do lar. Foram excluídas aquelas que se declararam estudantes.

- Renda individual mensal. Categorizada pelas faixas: até 1 salário mínimo (SM); mais de 1 a 3 SM; mais de 3 a 5 SM; mais de 5 a 7 SM; mais de 7 a 9 SM; mais de 9 SM. [O valor do salário mínimo no momento da entrevista era de $R \$ 120,00$ (cento e vinte reais)].

- Renda familiar per capita mensal (RFPC). Categorizada em: até 1 SM; mais de 1 a 3 SM; mais de 3 a 5 SM; mais de 5 a 7 SM; mais de 7 a 9 SM; mais de 9 SM. Renda calculada a partir da razão entre renda familiar mensal e número de pessoas que dependiam da mesma, incluindo aquelas pessoas que não moravam na mesma casa. [O valor do salário mínimo no momento da entrevista era de $\mathrm{R} \$ 120,00$ (cento e vinte reais)].

- Contribuição individual para a renda familiar mensal. Calculada a partir da expressão [(renda individual mensal/renda familiar mensal)*100] e categorizada em 4 faixas: até $25 \%$, mais de 25 a $50 \%$, mais de 50 a $75 \%$, mais de $75 \%$. Foram excluídas as mulheres que não declararam renda individual mensal.

- Número de pessoas que cuida. Categorizada em: nenhuma; 1 a 3 pessoas; 4 a 6 pessoas; 7 pessoas ou mais. Foram excluídas aquelas que moram em casas de apoio ou em casa de patrões (empregadas domésticas).

\subsubsection{Variáveis relacionadas ao teste e aos cuidados recebidos}

- Tempo de infecção diagnosticada. Categorizada em: 1 ano ou menos; de 2 a 4 anos; de 5 a 7 anos; de 8 a 10 anos; 11 anos ou mais. 
- Faixa etária no momento do diagnóstico. A idade foi agrupada em 5 classes: menos de 18 anos; de 18 a 25 anos: de 26 a 35 anos; de 36 a 45 anos; de 46 a 55 anos; 56 anos ou mais.

- Motivo para realização do teste. Apresentada em 3 categorias: solicitação do serviço de saúde; decisão própria; e outras razões. Divididas em subcategorias, os motivos citados como justificativas para a solicitação do teste pelo serviço de saúde foram: ficou doente; parceiro com diagnóstico de infecção ou doente de aids; rotina de pré-natal; filho com diagnóstico de infecção; e parto. Na categoria decisão própria, os motivos apresentados foram: precaução; achou que pudesse estar infectada; o companheiro era soropositivo. Dentre as outras razões para a solicitação do teste estavam: doação de sangue; exigência do trabalho; solicitação do parceiro; adoecimento do filho; sem explicação.

- Categoria de exposição. Quatro formas de exposição foram categorizadas: sexual; sanguínea; outras vias; e ignorada. As duas primeiras categorias foram subdivididas: sexual - parceiro(s) pouco conhecido(s); parceiro(s) infectado(s) em transfusão; parceiro(s) UDI(s); parceiro(s) infectado(s) por homem(ns), parceiro(s) infectado(s) por mulher(es), parceiro(s) infectado(s) por homem(ns) ou mulher(es), parceiro(s) com via(s) desconhecida(s) de exposição; e sanguínea - transfusão e UDI.

- Aconselhamento pré-teste. Categorizada em: sim, individual; sim, em grupo; não. Foram incluídas aquelas que sabiam que estavam sendo testadas e aquelas que não realizaram o teste em laboratório de análises clínicas.

- Atitude do profissional que entregou o resultado do teste. Categorizada em: conversou sobre o assunto (com ou sem encaminhamento); não conversou sobre o assunto (marcou nova consulta para conversar, encaminhou para outro serviço, com carta ou consulta marcada, encaminhou para outro serviço). Foram excluídas as mulheres que não receberam o resultado pessoalmente.

- Sensação despertada no momento da entrega do resultado. Categorizada em: apoio e atenção; indiferença; discriminação; crítica ou acusação; normal. Foram excluídas as mulheres que não receberam o resultado pessoalmente. 
- Tempo que demorou em procurar o serviço especializado. Categorizada em: menos de 1 mês; de 1 a 3 meses; de 4 a 6 meses; de 7 a 9 meses; 10 meses ou mais.

- Informações oferecidas pelo serviço especializado. Categorizadas em: transmissão durante a gravidez; transmissão durante o parto; transmissão durante a amamentação; terapia anti-retroviral durante a gravidez; terapia anti-retroviral para o bebê; prevenção de reinfecção; prevenção em parcerias sorodiscordantes; redução de danos no uso de drogas injetáveis; terapia antiretroviral; método contraceptivo mais adequado. Foram apresentadas somente as respostas positivas para cada uma das informações citadas e as categorias não eram excludentes.

\subsubsection{Variáveis relacionadas à vida sexual}

- Vida sexual após o diagnóstico. Variável dicotômica categorizada em: ativa e inativa.

- Qualidade da vida sexual após o diagnóstico. Categorizada em: ficou igual; piorou; melhorou; e ficou diferente. Foram excluídas as mulheres sexualmente inativas após o diagnóstico.

- Uso de preservativo masculino após o diagnóstico. Variável categorizada em função da freqüência de uso: nunca; às vezes; todas as vezes. Foram incluídas mulheres sexualmente ativas que relataram uso do preservativo masculino.

- Tipo de parceria atual. Categorizada em: estável (para aquelas com parceiro fixo) e eventual (para aquelas com parceiros eventuais). Foram excluídas as mulheres que não tinham parceiro sexual no momento da entrevista.

- Atividade sexual. Variável dicotômica, categorizada em: sim e não. Foram consideradas válidas as informações de mulheres com parceria fixa no momento da entrevista.

- Mora com parceiro fixo atual. Variável dicotômica, categorizada em: sim e não. Foram consideradas válidas as informações de mulheres com parceria fixa no momento da entrevista. 
- Condição sorológica do parceiro. Categorizada em: soropositivo; soronegativo; não sabe (porque nunca conversaram sobre o assunto, porque ele não fez o teste ou por razões não descritas). Foram considerados válidos os casos daquelas que declararam parceria sexual fixa no momento da entrevista.

- Parceiro sabe que você é portadora do HIV. Categorizada em: sim, não; e não sabe (porque nunca conversaram sobre o assunto ou por outras razões). Foram considerados válidos os casos daquelas que declararam parceria sexual fixa no momento da entrevista.

- Uso de preservativo. Variável categorizada em virtude da freqüência de uso: nunca; às vezes; todas as vezes. Foram incluídas mulheres sexualmente ativas, com parceria fixa no momento da entrevista e que relataram uso do preservativo masculino.

- Facilidade em obter preservativo masculino no serviço em que é atendida. Variável categorizada em: na maioria das vezes; às vezes; nunca. Foram considerados válidos os casos daquelas que fizeram a solicitação e que se relacionavam sexualmente com seus parceiros fixos.

\subsubsection{Variáveis relacionadas ao serviço de saúde, acesso e acolhimento}

- Profissional(is) por quem já foi atendida. Categorizada em: enfermeiro; psicólogo; assistente social; ginecologista; dentista; nutricionista; outro médico; outro profissional. Foram apresentadas somente as respostas positivas para cada um dos profissionais de saúde citados e as categorias não eram excludentes.

- Situações inadequadas vivenciadas no serviço de saúde. Variável apresentada em 4 categorias não excludentes: ser atendida sem ser olhada; ser tratada com discriminação ou preconceito; passar dor ou desconforto físico por erro do serviço; sofrer humilhação. Foram apresentadas somente as respostas positivas para tais situações (muitas vezes e poucas vezes).

- Facilidade em obter outros remédios além do coquetel. Variável categorizada em: na maioria das vezes; às vezes; nunca. Foram considerados válidos os casos daquelas que fizeram a solicitação. 
- Comunicação com o infectologista. Essa variável considera 3 planos de comunicação. O primeiro trata da facilidade em entender o que o profissional diz; o segundo refere-se à facilidade em falar sobre suas preocupações e tirar dúvidas; e o terceiro à facilidade em falar sobre sua vida sexual. Em todos os planos foi considerada a freqüência com que a facilidade ocorreu (na maioria das vezes; às vezes; nunca). Foram válidos os casos daquelas que já tinham recebido assistência do profissional em questão.

- Comunicação com o ginecologista. Essa variável considera 3 planos de comunicação. O primeiro trata da facilidade em entender o que o profissional diz; o segundo refere-se à facilidade em falar sobre suas preocupações e tirar dúvidas; e o terceiro à facilidade em falar sobre sua vida sexual. Em todos os planos foi considerada a freqüência com que a facilidade ocorreu (na maioria das vezes; às vezes; nunca). Foram válidos os casos daquelas que já tinham recebido assistência do profissional em questão.

\subsubsection{Variáveis que caracterizam a relação com o serviço e os cuidados com a saúde}

- Contagem de células TCD4. Variável categorizada em: até 200 células por $\mathrm{mm}^{3}$; de 200 a 350 células por $\mathrm{mm}^{3}$; mais de 350 células por $\mathrm{mm}^{3}$. Foram considerados válidos os casos daquelas que souberam informar o resultado do último exame.

- Significado do exame de CD4. Categorizada em: sabe (informação dada corretamente); e não sabe (resposta negativa ou informação dada incorretamente).

- Significado do exame de carga viral. Categorizada em: sabe (informação dada corretamente); e não sabe (resposta negativa ou informação dada incorretamente).

\subsection{Tratamento Estatístico}

\subsubsection{Análise univariada}

A descrição das variáveis segundo raça/cor foi feita por medidas de tendência central (médias e medianas) e por proporções. 
Para a análise univariada foi utilizado o programa SPSS versão 8.0. O estudo de associação entre as variáveis foi feito pelo teste $\chi^{2}$ Yates corrected, considerando um nível de confiança de $95 \%$ e $\alpha=5 \%$.

\subsubsection{Análise multivariada utilizando a técnica CHAID}

\subsubsection{Razões para a escolha da técnica}

A técnica CHAID (Chi-squared Automatic Interaction Detector) proposta por Kass (1980) tem caráter exploratório e procura classificar hierarquicamente os indivíduos utilizando-se de um modelo log-linear. É utilizada para estudar a relação entre uma variável dependente (qualitativa ou quantitativa) e uma série de variáveis preditoras que interagem entre si. Essa técnica de discriminação ou agrupamento é chamada hierárquica porque escolhe os objetos ou elementos de cada grupo em etapas, produzindo uma seqüência de partições, segundo a ordem de influência de suas medidas (variáveis independentes) sobre a variável dependente: os segmentos gerados a cada divisão são mutuamente excludentes e exaustivos e o resultado da análise é apresentado graficamente na forma de uma árvore de classificação (Biggs e col., 1991; Oliveira, 1996).

\subsubsection{A técnica CHAID}

Como descrito no capítulo de abordagens metodológicas de Oliveira (1996), a técnica CHAID estuda, para cada variável independente, todas as partições e agrupamentos de categorias em subgrupos possíveis (partição múltipla das categorias), procurando aquela que apresenta maior valor da estatística $\chi^{2}$ em uma tabela de dupla entrada com a variável dependente.

A partição do conjunto de dados é realizada de acordo com o agrupamento de categorias da variável discriminante estudada. Os agrupamentos formados são homogêneos internamente, porém heterogêneos entre si. Uma nova análise é feita dentro de cada subgrupo de categoria buscando-se estudar a influência de K-1 variáveis independentes, sempre utilizando como critério ótimo de seleção do agrupamento de categorias a estatística

$\chi^{2}$ de Pearson $\sum_{\mathrm{E}_{\mathrm{ij}}}\left(\underline{\mathrm{O}}_{\mathrm{ij}}-\mathrm{E}_{\mathrm{ij}}\right)^{2}$ ou a Razão de Verossimilhança $\chi^{2}:{ }_{\mathrm{ij}} \mathrm{O}_{\mathrm{ij}} \ln \left(\underline{\mathrm{O}}_{\mathrm{ij}}\right)$. 
Ao estudar uma variável dependente nominal, a técnica CHAID testa a independência entre a variável independente $(\mathbf{X})$ e a variável dependente $(\mathbf{Y})$ contra um modelo log-linear saturado do tipo: $\ln \left(\mathrm{E}_{\mathrm{ii}}\right)=\lambda+\lambda_{\mathrm{i}}^{\mathrm{X}}+\lambda_{\mathrm{j}}^{\mathrm{X}}+\lambda^{\mathrm{XY}}{ }_{\mathrm{ij}}$, onde $\lambda$ é o parâmetro referente a um valor geral, $\lambda^{\mathrm{X}}{ }_{\mathrm{i}}$ refere-se ao efeito da variável $\mathbf{X}$ sobre a casela $\mathrm{ij}, \lambda^{\mathrm{X}}{ }_{\mathrm{j}}$ refere-se ao efeito da variável $\mathbf{Y}$ sobre a casela $\mathrm{ij}$ e $\lambda^{\mathrm{XY}}{ }_{\mathrm{ij}}$ refere-se ao efeito da interação entre as variáveis $\mathbf{X}$ e $\mathbf{Y}$ naquela casela. Contudo, se a variável dependente for ordinal numérica, essa técnica testará a independência entre $\mathbf{X}$ e $\mathbf{Y}$ contra um modelo log-linear não saturado do tipo: $\ln \left(\mathrm{E}_{\mathrm{ii}}\right)=\lambda+\lambda_{\mathrm{i}}{ }+\lambda^{\mathrm{X}}{ }_{\mathrm{j}}+\theta_{\mathrm{i}}\left(\mathrm{y}_{\mathrm{j}}-\mathrm{y}\right)$, onde $y_{j}$ é uma categoria de $\mathbf{Y}$ e $\theta_{\mathrm{i}}$ um coeficiente desconhecido de $\mathrm{y}_{\mathrm{j}}$ para uma dada categoria $\mathbf{i}$ de $\mathbf{X}$.

O processamento desenvolvido pelo módulo Answer ${ }^{\circledR}$ Tree do pacote SPSS (algoritmo) segue as etapas propostas por Kass (1980) para procurar a melhor tabela de contingência:

$1^{0}$ passo: Para cada variável independente $(\mathbf{X})$ é construída uma tabela de dupla entrada de suas categorias, com as categorias da variável dependente (Y). A seguir é procurado o par de categorias de $\mathbf{X}$ menos significante, ou seja, aquela que, calculada a estatística $\chi^{2}$, apresenta o maior valor de $\mathbf{p}$ (nível descritivo do teste de associação).

Observação: $\mathrm{O}$ método estatístico utilizado para calcular o valor de $\mathbf{p}$ varia de acordo com o tipo da variável dependente (Y). Quando a variável dependente é qualitativa, as inter-relações são estudadas por meio de estatísticas qui-quadrado; quando a variável dependente é quantitativa, as inter-relações são estudadas por meio da razão de verossimilhança.

$\mathbf{2}^{\mathbf{0}}$ passo: O par de categorias de $\mathbf{X}$ (variável independente) com o maior valor de $\mathbf{p}$ é comparado ao valor crítico $\alpha$ preespecificado (nesse caso $\alpha=0,05$ ). Se o valor de $\mathbf{p}$ for maior que 0,05 , este par é agrupado em uma única categoria composta. Um novo bloco de categorias de $\mathbf{X}$ é formado e o procedimento é repetido para todas categorias existentes. Se, no entanto, o valor de $\mathbf{p}$ for menor que $\alpha$ crítico, a variável independente é selecionada e o conjunto de dados é subdividido de acordo com as categorias finais de $\mathbf{X}$.

Observação: As categorias que apresentam valores pequenos são agrupadas com aquelas de maior semelhança.

$3^{0}$ passo: Para cada segmento de dados resultantes da etapa anterior, o programa retorna à primeira etapa.

Observação: Cada subdivisão gerada recebe o nome de nó, ramo, ramificação ou, simplesmente, partição. 
O processo de geração de novos nós termina na ocorrência de uma das seguintes situações: 1. após a análise de todas as variáveis independentes; 2. na ausência de significância estatística nas associações, ou 3. quando o número de observações for pequeno demais por subgrupo.

O programa apresenta a análise dos dados em forma de árvore. Os últimos ramos da árvore são chamados terminais e definem um subgrupo de indivíduos classificados em um dos níveis da variável dependente: o nível (ou categoria) da variável dependente $(\mathbf{Y})$ que apresentar a maior proporção de indivíduos define sua classificação.

\subsubsection{Parâmetros estabelecidos para o uso da técnica e variáveis em estudo}

O valor do nível de significância fixado para a comparação de todos os testes das tabelas de contingência foi igual a 0,05 ( $\left.\alpha_{\text {crítico }}\right)$. Foram fixados o número máximo de níveis gerados (5), o tamanho mínimo do nó parental (100 casos) e o tamanho mínimo dos nós derivados (50 casos).

As análises foram realizadas para mulheres negras e mulheres não negras, separadamente. As variáveis independentes utilizadas na construção de todas as árvores foram: faixa etária; nível de escolaridade; renda individual mensal; renda familiar per capita mensal; contribuição individual para a renda familiar - aqui denominadas fatores estruturais. Outras variáveis independentes foram incorporadas ao conjunto de acordo com o objeto a ser estudado (variável dependente). De acordo com pergunta a ser respondida, os objetos passavam a figurar como predicados e vice-versa, conforme descrito no Quadro 1. 
Quadro 1. Variáveis estudadas na análise multivariada utilizando a técnica CHAID

\begin{tabular}{|c|c|}
\hline Variável Dependente & Variáveis Independentes \\
\hline a) Razão da testagem & $\begin{array}{l}\text { - faixa etária } \\
\text { - nível de escolaridade } \\
\text { - renda individual mensal } \\
\text { - renda familiar per capita mensal } \\
\text { - contribuição individual para a renda familiar } \\
\text { - tempo de infecção diagnosticada } \\
\text { - local onde realizou o teste } \\
\text { - percepção de risco } \\
\text { - faixa etária no momento do diagnóstico } \\
\text { - idade da iniciação sexual } \\
\text { - número de parceiros sexuais durante a vida }\end{array}$ \\
\hline b) Aconselhamento pré-teste & $\begin{array}{l}\text { Variáveis citadas no item a mais } \\
\text { - razão da testagem }\end{array}$ \\
\hline $\begin{array}{l}\text { c) Atitude do profissional que } \\
\text { entregou o resultado do teste }\end{array}$ & $\begin{array}{l}\text { Variáveis citadas no item b mais } \\
\text { - aconselhamento pré-teste } \\
\text { - categoria de exposição }\end{array}$ \\
\hline $\begin{array}{l}\text { d) Sensação despertada no } \\
\text { momento da entrega do } \\
\text { resultado }\end{array}$ & $\begin{array}{l}\text { Variáveis citadas no item c mais } \\
\text { - atitude do profissional que entregou o resultado do teste }\end{array}$ \\
\hline $\begin{array}{l}\text { e) Tempo que demorou em } \\
\text { procurar o serviço de saúde } \\
\text { especializado }\end{array}$ & $\begin{array}{l}\text { Variáveis citadas no item d mais } \\
\text { - número de filhos soropositivos } \\
\text { - número de pessoas que cuida } \\
\text { - sensação despertada no momento da entrega do resultado } \\
\text { - tempo que demorou em contar ao parceiro da época } \\
\text { - tempo que demorou em contar aos fillhos } \\
\text { - tempo que demorou em contar aos amigos } \\
\text { - tempo que demorou em contar no trabalho da época }\end{array}$ \\
\hline $\begin{array}{l}\text { f) Uso do preservativo } \\
\text { masculino após o } \\
\text { diagnóstico }\end{array}$ & $\begin{array}{l}\text { - faixa etária } \\
\text { - nível de escolaridade } \\
\text { - renda individual mensal } \\
\text { - renda familiar per capita mensal } \\
\text { - contribuição individual para a renda familiar } \\
\text { - tempo de infecção diagnosticada } \\
\text { - número de filhos soropositivos } \\
\text { - número de pessoas que cuida } \\
\text { - tipo de parceria atual } \\
\text { - condição sorológica do parceiro } \\
\text { - parceiro sabe que é soropositiva } \\
\text { - pensa em ter filhos } \\
\text { - tempo de infecção diagnosticada } \\
\text { - informação sobre transmissão durante a gravidez } \\
\text { - informação sobre prevenção de reinfecção } \\
\text { - informação sobre prevenção em parcerias sorodiscordantes } \\
\text { - informação sobre terapia anti-retroviral } \\
\text { - facilidade para entender o que o infectologista diz } \\
\text { - facilidade para falar sobre suas preocupações e tirar dúvidas com o } \\
\text { infectologista } \\
\text { - facilidade em falar sobre sua vida sexual com o infectologista } \\
\text { - facilidade para entender o que o ginecologista diz } \\
\text { - facilidade para falar sobre suas preocupações e tirar dúvidas com o } \\
\text { ginecologista } \\
\text { - facilidade em falar sobre sua vida sexual com o ginecologista } \\
\text { - contagem de células TCD4 } \\
\text { - significado do exame de CD4 } \\
\text { - significado do exame de carga viral } \\
\end{array}$ \\
\hline
\end{tabular}


Quadro 1. Variáveis estudadas na análise multivariada utilizando a técnica CHAID

\begin{tabular}{|c|c|}
\hline Variável Dependente & Variáveis Independentes \\
\hline $\begin{array}{l}\text { g) Facilidade em obter outros } \\
\text { remédios além do coquetel }\end{array}$ & $\begin{array}{l}\text { - faixa etária } \\
\text { - nível de escolaridade } \\
\text { - renda individual mensal } \\
\text { - renda familiar per capita mensal } \\
\text { - contribuição individual para a renda familiar } \\
\text { - número de filhos soropositivos } \\
\text { - número de pessoas que cuida } \\
\text { - tipo de parceria atual } \\
\text { - tempo de infecção diagnosticada } \\
\text { - meios de acesso ao serviço especializado } \\
\text { - tempo gasto para chegar ao serviço de saúde onde se trata } \\
\text { - tempo de segmento no serviço de saúde } \\
\text { - freqüência de falta às consultas } \\
\text { - contagem de células TCD4 } \\
\text { - significado do exame CD4 } \\
\text { - significado do exame de carga viral }\end{array}$ \\
\hline $\begin{array}{l}\text { h) Facilidade em entender o } \\
\text { que o infectologista diz }\end{array}$ & $\begin{array}{l}\text { - faixa etária } \\
\text { - nível de escolaridade } \\
\text { - renda individual mensal } \\
\text { - renda familiar per capita mensal } \\
\text { - contribuição individual para a renda familiar } \\
\text { - tempo de infecção diagnosticada } \\
\text { - tempo de segmento no serviço de saúde } \\
\text { - facilidade em falar sobre suas preocupações e tirar dúvidas com o } \\
\text { infectologista } \\
\text { - facilidade em falar sobre sua vida sexual com o infectologista } \\
\text { - freqüência de falta às consultas }\end{array}$ \\
\hline $\begin{array}{l}\text { i) Facilidade em falar sobre sua } \\
\text { vida sexual com o } \\
\text { infectologista }\end{array}$ & $\begin{array}{l}\text { - faixa etária } \\
\text { - nível de escolaridade } \\
\text { - renda individual mensal } \\
\text { - renda familiar per capita mensal } \\
\text { - contribuição individual para a renda familiar } \\
\text { - número de filhos soropositivos } \\
\text { - número de pessoas que cuida } \\
\text { - número de parceiros sexuais durante a vida } \\
\text { - tipo de parceria atual } \\
\text { - condição sorológica do parceiro } \\
\text { - uso de preservativo } \\
\text { - pensa em ter filhos } \\
\text { - tempo de infecção diagnosticada } \\
\text { - informação sobre transmissão durante a gravidez } \\
\text { - informação sobre prevenção de reinfecção } \\
\text { - informação sobre terapia anti-retroviral } \\
\text { - facilidade em entender o que o infectologista diz } \\
\text { - facilidade em falar sobre suas preocupações e tirar dúvidas com o } \\
\text { infectologista } \\
\text { - facilidade em entender o que o ginecologista diz } \\
\text { - facilidade em falar sobre suas preocupações e tirar dúvidas com o } \\
\text { - ginecologista } \\
\text { - cocilidade em falar sobre sua vida sexual com o ginecologista } \\
\text { - significado do exame de CD4 } \\
\text { - significado do exame de carga viral } \\
\end{array}$ \\
\hline
\end{tabular}


Quadro 1. Variáveis estudadas na análise multivariada utilizando a técnica CHAID

(conclusão)

\begin{tabular}{|l|l|}
\hline Variável Dependente & Variáveis Independentes \\
\hline j) Facilidade em entender o que & - faixa etária \\
o ginecologista diz & - nível de escolaridade \\
& - renda individual mensal \\
& - renda familiar per capita mensal \\
- contribuição individual para a renda familiar \\
- tempo de infecção diagnosticada \\
- tempo de segmento no serviço de saúde \\
\\
- facilidade em falar sobre suas preocupações e tirar dúvidas com o \\
ginecologista \\
facilidade em falar sobre sua vida sexual com o ginecologista \\
- freqüência de falta às consultas \\
\hline $\begin{array}{l}\text { k) Facilidade em falar sobre } \\
\text { sua vida sexual com o } \\
\text { ginecologista }\end{array}$ & $\begin{array}{l}\text { Variáveis descritas no item i, com exceção de "facilidade em falar } \\
\text { sobre sua vida sexual com o ginecologista". Ocupa seu lugar a } \\
\text { variável "facilidade em falar de sua vida sexual com o } \\
\text { infectologista". }\end{array}$ \\
\hline
\end{tabular}




\section{RESULTADOS}

A vulnerabilidade individual é estabelecida num espaço de relações entre sujeitos e pode ser aumentada ou diminuída na medida em que essas relações tendem à (des)igualdade; por isso é impossível conhecer as partes sem conhecer o todo, bem como é impossível compreender o todo apenas pela soma dos comportamentos ou das características das partes.

\subsection{Análise Univariada}

\subsubsection{Características sociodemográficas}

Foram incluídas no estudo 1.068 mulheres - 526 não negras ( $49,3 \%$ do total) e 542 negras $(50,7 \%)$. O CRAIDS foi o serviço com maior proporção de mulheres negras entrevistadas $(60,8 \%)$.

A média de idade das entrevistadas foi de 36,1 anos $( \pm 9,0 \mathrm{dp})$. O valor médio referente à idade apresentou-se ligeiramente maior entre as negras (36,4 versus 35,8 anos). A média de anos de estudo para o total de mulheres foi de 7,7, a média caiu para as negras ( 6,9 anos) e aumentou para as não negras ( 7,8 anos).

As distribuições por faixa etária e nível de escolaridade são apresentadas na Tabela 5. Em ambos os grupos (mulheres negras e não negras), a maior concentração de mulheres foi observada na faixa etária de 26 a 35 anos, cabendo destacar que a proporção de mulheres com 56 anos ou mais foi maior entre as negras. A diferença entre o nível de escolaridade de mulheres negras e não negras foi nítida e estatisticamente significante $(\mathrm{p}<0,000)$, sendo maiores as possibilidades de as negras não terem instrução ou de possuírem apenas o ensino fundamental. 
Tabela 5. Distribuição da população por faixa etária e nível de escolaridade, segundo raça/cor. São Paulo, 2000.

\begin{tabular}{|c|c|c|c|}
\hline Variável & $\begin{array}{c}\text { Total } \\
\text { V. Abs. }(\%)\end{array}$ & $\begin{array}{l}\text { Negra } \\
(\%)\end{array}$ & $\begin{array}{c}\text { Não Negra } \\
(\%)\end{array}$ \\
\hline \multicolumn{4}{|l|}{ Faixa etária (anos) } \\
\hline $18-25$ & $103 \quad(9,7)$ & 10,4 & 9,0 \\
\hline $26-35$ & $437(41,2)$ & 38,7 & 43,9 \\
\hline $36-45$ & $366(34,5)$ & 36,0 & 32,9 \\
\hline $46-55$ & $112(10,6)$ & 9,9 & 11,3 \\
\hline 56 ou mais & $42 \quad(4,0)$ & 5,0 & 2,9 \\
\hline \multirow[t]{2}{*}{ Total [V. Abs. (\%)] } & $1.060(100,0)$ & $538(100,0)$ & $522(100,0)$ \\
\hline & \multicolumn{3}{|c|}{$\chi^{2}$ Pearson $=6,628 ; \mathrm{p}<0,157$ (4 g.l. } \\
\hline \multicolumn{4}{|l|}{ Nível de escolaridade } \\
\hline Nenhum & $37 \quad(3,5)$ & 5,0 & 1,9 \\
\hline Ensino fundamental 1 & $206(19,3)$ & 24,3 & 14,1 \\
\hline Ensino fundamental 2 & $373(35,0)$ & 38,0 & 31,9 \\
\hline Ensino médio (in)completo & $331(31,0)$ & 26,2 & 36,1 \\
\hline Ensino superior (in)completo & $119(11,2)$ & 6,5 & 16,0 \\
\hline \multirow{2}{*}{ Total [V. Abs. (\%)] } & $1.066(100,0)$ & $542(100,0)$ & $524(100,0)$ \\
\hline & \multicolumn{3}{|c|}{$\chi^{2}$ Pearson $=54,781 ; p<0,000(4$ g.l. $)$} \\
\hline
\end{tabular}

Em ambos os grupos, a maioria das mulheres relatou habitar casa de tijolos, de 4 a 6 cômodos. Habitações com menor número de cômodos foram citadas mais por mulheres negras. A variável "número de cômodos" apresentou-se estatisticamente diferente em relação à raça/cor das entrevistadas nas análises simples e combinada (número de cômodos em casa de tijolo; número de cômodos em apartamento), conforme descrito na Tabela 6. Cabe ressaltar aqui que todas as mulheres moradoras de rua e moradoras de casa de apoio eram negras (dados estes não apresentados). 
Tabela 6. Distribuição da população por condições de moradia e habitação, segundo raça/cor. São Paulo, 2000.

\begin{tabular}{|c|c|c|c|}
\hline Variável & Total & $\begin{array}{c}\text { Negra } \\
(\%) \\
\end{array}$ & $\begin{array}{c}\text { Não Negra } \\
(\%) \\
\end{array}$ \\
\hline \multicolumn{4}{|l|}{ Tipo de habitação } \\
\hline Casa de tijolo & $710(67,5)$ & 69,7 & 65,3 \\
\hline Apartamento & $264(25,1)$ & 21,7 & 28,4 \\
\hline Casa de madeira & $51 \quad(4,8)$ & 5,9 & 3,8 \\
\hline Casa de cômodos & $27 \quad(2,6)$ & 2,7 & 2,5 \\
\hline \multirow[t]{2}{*}{ Total $^{(\mathbf{a})}[$ V. Abs. (\%)] } & $1.052(100,0)$ & $528(100,0)$ & $524(100,0)$ \\
\hline & \multicolumn{3}{|c|}{$\chi^{2}$ Pearson $=7,725 ; \mathrm{p}<0,052(3$ g.l. $)$} \\
\hline \multicolumn{4}{|l|}{ Número de cômodos } \\
\hline $1-3$ & $230 \quad(22,5)$ & 26,5 & 18,5 \\
\hline $4-6$ & $605 \quad(59,3)$ & 59,1 & 59,6 \\
\hline 7 ou mais & $185 \quad(18,2)$ & 14,4 & 21,9 \\
\hline \multirow[t]{2}{*}{ Total $^{(\mathbf{b})}[$ V. Abs. (\%)] } & $1.020(100,0)$ & $513(100,0)$ & $507(100,0)$ \\
\hline & \multicolumn{3}{|c|}{$\chi^{2}$ Pearson $=15,036 ; \mathrm{p}<0,001$ (2 g.l.) } \\
\hline \multicolumn{4}{|l|}{ Condiç̃es de moradia } \\
\hline \multicolumn{4}{|l|}{ - Casa de tijolo } \\
\hline $1-3$ cômodos & $178 \quad(25,4)$ & 27,7 & 22,8 \\
\hline 4-6 cômodos & $373(53,1)$ & 54,7 & 51,5 \\
\hline 7 ou mais cômodos & $151 \quad(21,5)$ & 17,6 & 25,7 \\
\hline \multirow[t]{2}{*}{ Total [V. Abs. (\%)] } & $702(100,0)$ & $364(100,0)$ & $338(100,0)$ \\
\hline & \multicolumn{3}{|c|}{$\chi^{2}$ Pearson $=7,462 ; \mathrm{p}<0,024(2$ g.l. $)$} \\
\hline \multicolumn{4}{|l|}{ - Apartamento } \\
\hline $1-3$ cômodos & $28 \quad(10,6)$ & 15,9 & 6,7 \\
\hline 4-6 cômodos & $202(76,8)$ & 75,4 & 77,9 \\
\hline 7 ou mais cômodos & $33 \quad(12,5)$ & 8,8 & 15,4 \\
\hline \multirow[t]{2}{*}{ Total [V. Abs. (\%)] } & $263(100,0)$ & $114(100,0)$ & $149(100,0)$ \\
\hline & \multicolumn{3}{|c|}{$\chi^{2}$ Pearson $=7,334 ; p<0,026$ (2 g.l. $)$} \\
\hline \multicolumn{4}{|l|}{ - Casa de madeira } \\
\hline 1-3 cômodos & $22(44,0)$ & 50,0 & 35,0 \\
\hline 4-6 cômodos & $27 \quad(54,0)$ & 50,0 & 60,0 \\
\hline 7 ou mais cômodos & $1 \quad(2,0)$ & - & 5,0 \\
\hline \multirow[t]{2}{*}{ Total [V. Abs. (\%)] } & $50(100,0)$ & $30(100,0)$ & $20(100,0)$ \\
\hline & \multicolumn{3}{|c|}{$\chi^{2}$ Pearson $=2,336 ; \mathrm{p}<0,311(2$ g.l. $)$} \\
\hline
\end{tabular}

Notas: (a) Excluindo 6 mulheres moradoras de casa de apoio (4 negras e 2 não negras) e 4 moradoras de rua (todas negras).

(b) Excluindo aquelas que residiam em casas de cômodos e aquelas que não souberam ou quiseram informar.

Em relação à participação no mercado de trabalho, mais da metade das mulheres estudadas estavam economicamente ativas. Negras e não negras apresentaram padrões semelhantes de distribuição (Tabela 7). 
Tabela 7. Distribuição da população por ocupação, segundo raça/cor.

São Paulo, 2000.

\begin{tabular}{|c|c|c|c|}
\hline \multirow{2}{*}{ Ocupação } & Total & Negras & Não Negras \\
\hline & V. Abs. (\%) & $(\%)$ & $(\%)$ \\
\hline \multicolumn{4}{|l|}{ Ativas } \\
\hline Trabalho formal & $317 \quad(50,0)$ & 49,1 & 51,0 \\
\hline Trabalho informal $^{(\mathbf{a})}$ & $122(19,2)$ & 18,9 & 19,6 \\
\hline Autônoma (contribuinte) & $11 \quad(1,8)$ & 1,8 & 1,6 \\
\hline Desempregada & $184(29,0)$ & 30,2 & 27,8 \\
\hline \multirow[t]{2}{*}{ Total $^{(b)}[$ V. Abs. (\%)] } & $634(100,0)$ & $328(100,0)$ & $306(100,0)$ \\
\hline & \multicolumn{3}{|c|}{$\chi^{2}$ Pearson $=0,505 ; \mathrm{p}<0,918(3$ g.1. $)$} \\
\hline \multicolumn{4}{|l|}{ Inativas } \\
\hline 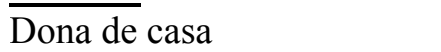 & $139(32,3)$ & 32,7 & 32,0 \\
\hline Aposentada & $83 \quad(19,3)$ & 19,4 & 19,2 \\
\hline Previdência social & $108(25,1)$ & 26,6 & 23,7 \\
\hline Parou de procurar emprego & $100(23,3)$ & 21,3 & 25,1 \\
\hline \multirow[t]{2}{*}{ Total $^{(\mathrm{c})}$ [V. Abs. (\%)] } & $430(100,0)$ & $211(100,0)$ & $219(100,0)$ \\
\hline & \multicolumn{3}{|c|}{$\chi^{2}$ Pearson $=1,019 ; \mathrm{p}<0,797$ (3 g.l.) } \\
\hline
\end{tabular}

Notas: (a) Incluindo as trabalhadoras do sexo.

(b) Total de mulheres economicamente ativas.

(c) Total de mulheres economicamente inativas, excluindo 4 estudantes (3 negras e 1 não negra).

Para as ocupadas, os rendimentos médios mensais foram de $\mathrm{R} \$ 552,82$. Para as negras, o salário individual médio equivalia a $\mathrm{R} \$ 345,00$ e para as não negras $\mathrm{R} \$$ 661,15. A renda familiar per capita mensal (RFPC) média também diferiu nos dois grupos. Independentemente da raça/cor, a média de rendimento mensal familiar per capita foi de R\$975,11. Para as negras, a média foi menor que para as não negras, R\$ 730,98 versus R\$ 1.229,41. Como as médias são influenciadas pelos valores extremos, na Figura 1 foram apresentadas medianas da renda individual mensal e da RFPC. 
Figura 1. Renda individual mediana e renda familiar per capita mediana, segundo raça/cor. São Paulo, 2000.

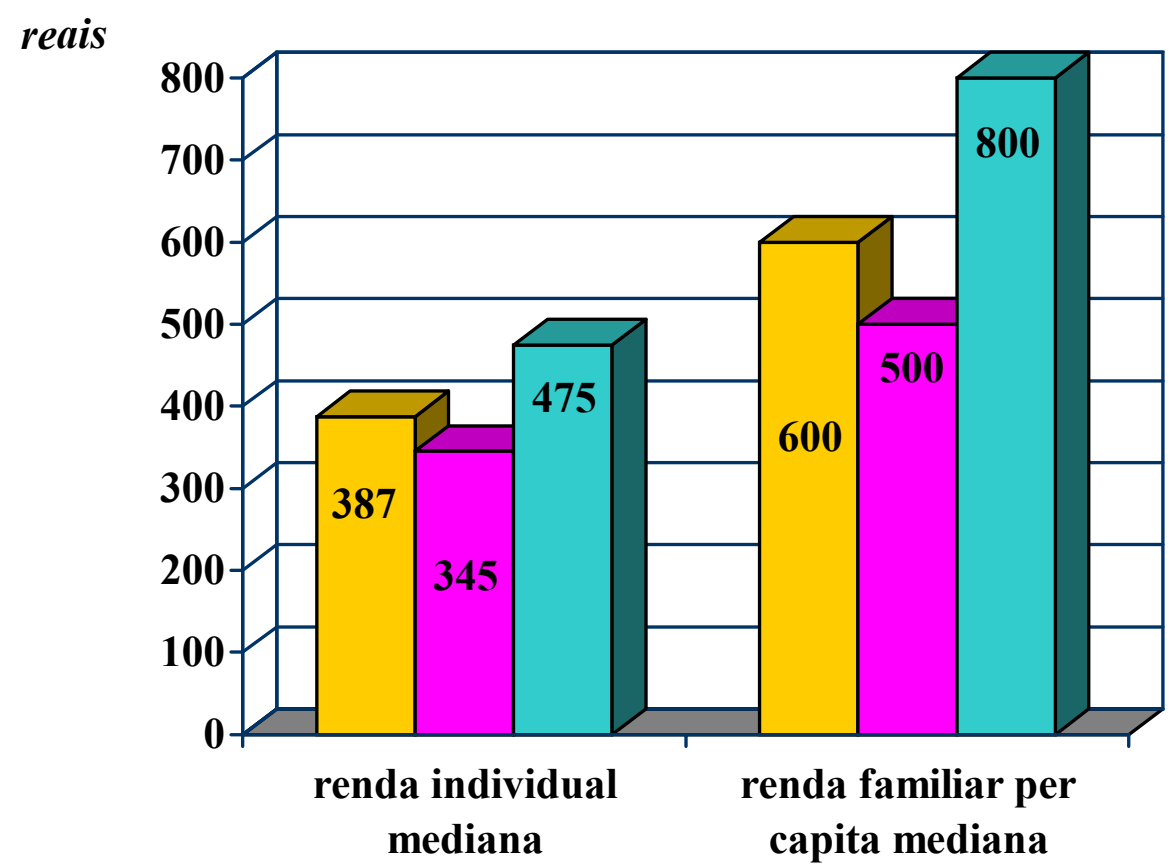

Total $\square$ Negras $\square$ Não Negras

Os dados apresentados na Tabela 8 confirmam a constatação das diferenças estatisticamente significantes no rendimento individual e familiar de negras e não negras. No tocante à contribuição individual mensal para o orçamento familiar, grande parte das mulheres (66\% das negras e 57,5\% das não negras) era responsável por mais da metade da renda familiar mensal. Além da responsabilidade financeira, as mulheres também se dedicavam ao cuidado com os demais membros da família especialmente as negras $(\mathrm{p}<0,007)$.

Embora ambos os grupos apresentassem prevalência de baixos salários e baixos rendimentos familiares, apenas $32,3 \%$ recebiam algum tipo de auxílio material (cesta básica, roupa, vale transporte, vale alimentação, dinheiro). A ajuda na realização do trabalho doméstico também foi pouco comum: $47,7 \%$ para as negras e 49,8\% para as não negras (dados não apresentados em tabelas). 
Tabela 8. Distribuição da população por renda individual, renda familiar per capita e contribuição para o orçamento familiar, segundo raça/cor. São Paulo, 2000.

\begin{tabular}{|c|c|c|c|}
\hline Variável & $\begin{array}{c}\text { Total } \\
\text { V. Abs. } \\
(\%) \\
\end{array}$ & $\begin{array}{c}\text { Negra } \\
(\%)\end{array}$ & $\begin{array}{c}\text { Não Negra } \\
(\%)\end{array}$ \\
\hline \multicolumn{4}{|c|}{$\underline{\text { Renda individual mensal (SM) }}$} \\
\hline Até 1 & $106(14,5)$ & 15,4 & 13,5 \\
\hline Mais de 1 a 3 & $297(40,5)$ & 47,4 & 33,4 \\
\hline Mais de 3 a 5 & $137(18,7)$ & 19,4 & 18,0 \\
\hline Mais de 5 a 7 & $89(12,1)$ & 10,0 & 14,4 \\
\hline Mais de 7 a 9 & $48(6,5)$ & 4,3 & 8,8 \\
\hline Mais de 9 & $56(7,6)$ & 3,5 & 11,9 \\
\hline \multirow[t]{2}{*}{ Total [V. Abs. (\%)] } & $733(100,0)$ & $371(100,0)$ & $362(100,0)$ \\
\hline & \multicolumn{3}{|c|}{$\chi^{2}$ Pearson $=34,974 ; \mathrm{p}<0,000(5$ g.l. $)$} \\
\hline \multicolumn{4}{|c|}{ Renda familiar per capita mensal (SM) } \\
\hline Até 1 & $373(38,2)$ & 45,3 & 30,8 \\
\hline Mais de 1 a 3 & $392(40,0)$ & 41,3 & 38,8 \\
\hline Mais de 3 a 5 & $106(10,8)$ & 8,0 & 13,8 \\
\hline Mais de 5 a 7 & $41(4,2)$ & 3,0 & 5,4 \\
\hline Mais de 7 a 9 & $27(2,8)$ & 1,0 & 4,6 \\
\hline Mais de 9 & $39(4,0)$ & 1,4 & 6,7 \\
\hline \multirow[t]{2}{*}{ Total [V. Abs. (\%)] } & $979(100,0)$ & $499(100,0)$ & $480(100,0)$ \\
\hline & $\chi^{2}$ Pea & \multirow{2}{*}{\multicolumn{2}{|c|}{$\chi^{2}$ Pearson $=52,997 ; \mathrm{p}<0,000(5$ g.l. $)$}} \\
\hline \multicolumn{2}{|l|}{$\begin{array}{l}\text { Contribuicao indivi } \\
\text { familiar (\%) }\end{array}$} & & \\
\hline Até 25 & $86(12,4)$ & 11,1 & 13,6 \\
\hline Mais de 25 a 50 & $179(25,8)$ & 22,9 & 28,9 \\
\hline Mais de 50 a 75 & $119(17,2)$ & 19,4 & 14,9 \\
\hline Mais de $75 \%$ & $309(44,6)$ & 46,6 & 42,6 \\
\hline \multirow[t]{2}{*}{ Total [V. Abs. (\%)] } & $693(100,0)$ & $350(100,0)$ & $343(100,0)$ \\
\hline \multirow{2}{*}{\multicolumn{4}{|c|}{$\chi^{2}$ Pearson $=6,055 ; \mathrm{p}<0,109$ (3 g.l. $)$}} \\
\hline & & & \\
\hline Nenhuma & $156(14,8)$ & 13,2 & 16,5 \\
\hline $1-3$ & $667(63,5)$ & 62,7 & 64,2 \\
\hline $4-6$ & $202(19,2)$ & 20,1 & 18,3 \\
\hline 7 ou mais & $26(2,5)$ & 4,0 & 1,0 \\
\hline \multirow[t]{2}{*}{ Total [V. Abs. (\%)] } & $1.051(100,0)$ & $531(100,0)$ & $520(100,0)$ \\
\hline & \multicolumn{3}{|c|}{$\chi^{2}$ Pearson $=12,088 ; \mathrm{p}<0,007$ (3 g.l. $)$} \\
\hline
\end{tabular}

Nota: $(*)$ Excluindo as mulheres que moram em casa de família ou em casa de apoio.

\subsubsection{Teste e cuidados recebidos}

Muitas das mulheres envolvidas no presente estudo tiveram sua infecção diagnosticada recentemente - há 4,36 anos $( \pm 3,16 \mathrm{dp})$ em média. No momento do diagnóstico, elas tinham, em média, 31,77 anos de idade $( \pm 9,26 \mathrm{dp})$. Antes de receberem o resultado do teste, apenas 33,5\% das mulheres negras e 34,0\% das mulheres não negras acreditavam estar infectadas. A Tabela 9 apresenta a 
distribuição da população por tempo de infecção diagnosticada e faixa etária no momento do diagnóstico.

Tabela 9. Distribuição da população por tempo de infecção diagnosticada e por faixa etária no momento do diagnóstico, segundo raça/cor. São Paulo, 2000.

\begin{tabular}{|c|c|c|c|}
\hline Variável & Total & $\frac{\text { Negra }}{(\%)}$ & $\begin{array}{c}\text { Não Negra } \\
(\%)\end{array}$ \\
\hline \multicolumn{4}{|c|}{ Tempo de infeccão diagnosticada (anos) } \\
\hline 1 ou menos & $240(22,5)$ & 25,4 & 19,6 \\
\hline $2-4$ & $502(47,1)$ & 46,7 & 47,5 \\
\hline $5-7$ & $145(13,6)$ & 13,5 & 13,7 \\
\hline $8-10$ & $144(13,5)$ & 12,0 & 15,0 \\
\hline 11 ou mais & $35 \quad(3,3)$ & 2,4 & 4,2 \\
\hline \multirow[t]{2}{*}{ Total [V. Abs. (\%)] } & $1.066(100,0)$ & $540(100,0)$ & $526(100,0)$ \\
\hline & \multicolumn{3}{|c|}{$\chi^{2}$ Pearson $=8,324 ; \mathrm{p}<0,080$ (4 g.1. $)$} \\
\hline \multicolumn{4}{|c|}{ Faixa etária no momento do diagnóstico (anos) } \\
\hline Menos de 18 & $26 \quad(2,5)$ & 1,7 & 3,2 \\
\hline $18-25$ & $259(24,3)$ & 23,4 & 25,3 \\
\hline $26-35$ & $469(44,1)$ & 44,3 & 43,9 \\
\hline $36-45$ & $211(19,8)$ & 20,9 & 18,7 \\
\hline $46-55$ & $76 \quad(7,1)$ & 7,1 & 7,2 \\
\hline 56 ou mais & $23 \quad(2,2)$ & 2,6 & 1,7 \\
\hline \multirow[t]{2}{*}{ Total [V. Abs. (\%)] } & $1.064(100,0)$ & $539(100,0)$ & $525(100,0)$ \\
\hline & \multicolumn{3}{|c|}{$\chi^{2}$ Pearson $=4,793 ; p<0,442$ (5 g.l.) } \\
\hline
\end{tabular}

Quarenta e um por cento das mulheres foram testadas em hospitais, 19,2\% em laboratórios privados de análises clínicas, 18,6\% em unidades básicas de saúde (UBS) e 15,3\% em serviços especializados (centros de referência para tratamento/acompanhamento de pessoas vivendo com HIV/AIDS ou centros de testagem anônima). Algumas realizaram o teste em maternidade $(1,7 \%)$, outras em banco de sangue ou leite $(1,9 \%)$ e outras não especificaram o local (2,3\%). Mais da metade das mulheres $(56,7 \%)$ realizou o teste por solicitação do serviço de saúde, $20,0 \%$ o fizeram por decisão própria e $23,2 \%$ por outras razões. Em um nível de significância de $5 \%$, a razão da testagem mostrou-se estatisticamente diferente em relação à raça/cor das entrevistadas, com especial atenção para a situação em que o teste foi solicitado pelo serviço de saúde $\left(\chi^{2}\right.$ Pearson $\left.=9,181 ; p<0,010\right)$. Tais dados não são apresentados em tabela.

A Tabela 10 mostra que, embora algumas mulheres não soubessem precisar a razão da testagem, para aquelas que tiveram o teste solicitado pelo serviço de saúde, os motivos mais freqüentes, em ambos os grupos, foram: adoecimento $(45,9 \%)$ e 
diagnóstico de infecção por HIV ou adoecimento do parceiro por aids $(33,4 \%)$; dentre aquelas que decidiram fazer o teste, grande parte achou que pudesse estar infectada (63,9\%). Também foi comum a realização do teste para doação de sangue (20,2\% do total de mulheres que citou outras razões para a realização do teste).

Tabela 10. Distribuição da população segundo razão da testagem e raça/cor. São Paulo, 2000.

\begin{tabular}{|c|c|c|c|}
\hline \multirow{2}{*}{ Razão da Testagem } & Total & Negra & Não Negra \\
\hline & V. Abs. (\%) & $(\%)$ & $(\%)$ \\
\hline \multicolumn{4}{|l|}{ Solicitação do serviço de saúde } \\
\hline Porque ficou doente & $276(46,0)$ & 47,1 & 44,5 \\
\hline $\begin{array}{l}\text { Porque o parceiro foi diagnosticado } \\
\text { soropositivo ou doente de aids }\end{array}$ & $201(33,4)$ & 34,0 & 32,7 \\
\hline Rotina de pré-natal & $100(16,6)$ & 14,7 & 19,1 \\
\hline Filho nasceu soropositivo & $15(2,5)$ & 3,0 & 1,8 \\
\hline Por ocasião do parto & $9(1,5)$ & 1,2 & 1,9 \\
\hline \multirow[t]{2}{*}{ Total $^{(\mathrm{a})}[$ V. Abs. (\%)] } & $601(100,0)$ & $329(100,0)$ & $272(100,0)$ \\
\hline & \multicolumn{3}{|c|}{$\chi^{2}$ Pearson $=3,382 ; \mathrm{p}<0,496$ (4 g.l. $)$} \\
\hline \multicolumn{4}{|l|}{ Decisão própria } \\
\hline Precaução & $58(23,8)$ & 18,2 & 28,4 \\
\hline Achou que pudesse estar infectada & $156(63,9)$ & 66,4 & 61,9 \\
\hline Porque o companheiro era soropositivo & $30(12,3)$ & 15,4 & 9,7 \\
\hline \multirow[t]{2}{*}{ Total $^{(\mathbf{b})}[$ V. Abs. (\%)] } & $244(100,0)$ & $110(100,0)$ & $134(100,0)$ \\
\hline & \multicolumn{3}{|c|}{$\chi^{2}$ Pearson $=4,443 ; p<0,108(2$ g.l. $)$} \\
\hline \multicolumn{4}{|l|}{ Outras razões } \\
\hline$\overline{\text { Doação de sangue }}$ & $44(20,2)$ & 22,8 & 17,9 \\
\hline Por exigência do trabalho & $4(1,8)$ & 1,0 & 2,6 \\
\hline Por solicitação do parceiro & $13(5,9)$ & 4,9 & 6,8 \\
\hline Porque o filho adoeceu & $18(8,3)$ & 8,9 & 7,7 \\
\hline Sem explicação & $139(63,8)$ & 62,4 & 65,0 \\
\hline \multirow[t]{2}{*}{ Total $^{(\mathrm{c})}$ [V. Abs. (\%)] } & $218(100,0)$ & $101(100,0)$ & $117(100,0)$ \\
\hline & \multicolumn{3}{|c|}{$\chi^{2}$ Pearson $=1,835 ; \mathrm{p}<0,766(4$ g.l. $)$} \\
\hline
\end{tabular}

Notas: (a) Excluindo aquelas que não souberam a razão da solicitação do teste $(n=5)$.

(b) Total de mulheres que fizeram o teste por iniciativa própria.

(c) Total de mulheres que tiveram o teste realizado por outras razões explicitadas ou não durante a entrevista.

A infecção por via sexual foi a mais citada pelas mulheres entrevistadas $(81,4 \%)$, seguida pela via sanguínea $(8,9 \%)$, via ignorada $(5,4 \%)$ e outras vias $(4,3 \%)$. As mulheres negras relataram infecção pela via sexual em 79,7\% dos casos e as não negras em 83,1\%; enquanto a via sanguínea esteve nos relatos de $9,5 \%$ das negras e $8,3 \%$ das não negras.

Para cada uma dessas vias foram descritas na Tabela 11 as categorias de exposição ao vírus, mostrando que, para a via sexual, as relações desprotegidas com 
parceiro infectado por mulher ou com parceiro usuário de droga injetável foram as mais comuns para mulheres negras e não negras, cabendo ressaltar que as não negras relataram, mais freqüentemente, o envolvimento com parceiro(s) UDI(s) e as negras o envolvimento com parceiro infectado por outra mulher. Outras, embora reconheçam a infecção pela via sexual, desconhecem a via de infecção do parceiro. Mais da metade daquelas que relataram infecção por via sanguínea eram UDIs.

Tabela 11. Distribuição da população por categoria de exposição, segundo raça/cor. São Paulo, 2000.

\begin{tabular}{|c|c|c|c|}
\hline Categoria de Exposição & $\begin{array}{c}\text { Total } \\
\text { V. Abs. }(\%)\end{array}$ & $\begin{array}{c}\text { Negra } \\
(\%)\end{array}$ & $\frac{\text { Não Negra }}{(\%)}$ \\
\hline \multicolumn{4}{|l|}{ Sexual } \\
\hline Parceiro(s) pouco conhecido(s) & $71 \quad(8,2)$ & 6,7 & 9,7 \\
\hline Parceiro infectado em transfusão & $7 \quad(0,8)$ & 0,5 & 1,2 \\
\hline Parceiro(s) UDI(s) & $245 \quad(28,4)$ & 23,3 & 33,5 \\
\hline Parceiro infectado por homem & $24 \quad(2,8)$ & 4,0 & 1,6 \\
\hline Parceiro infectado por mulher & $319(37,0)$ & 40,1 & 33,9 \\
\hline $\begin{array}{l}\text { Parceiro infectado por homem ou } \\
\text { mulher }\end{array}$ & $44 \quad(5,1)$ & 4,9 & 5,3 \\
\hline $\begin{array}{l}\text { Desconhece a via de infecção do } \\
\text { parceiro }\end{array}$ & $152(17,7)$ & 20,5 & 14,8 \\
\hline Total $^{(\mathbf{a})}[$ V. Abs. (\%)] & $862(100,0)$ & $429(100,0)$ & $433(100,0)$ \\
\hline \multicolumn{4}{|c|}{$\chi^{2}$ Pearson $=21,920 ; \mathrm{p}<0,001$ (6 g.1.) } \\
\hline \multicolumn{4}{|l|}{ Sanguínea } \\
\hline $\overrightarrow{\text { Transfusão }}$ & $38(40,4)$ & 41,2 & 39,5 \\
\hline UDI & $56(59,6)$ & 58,8 & 60,5 \\
\hline Total $^{(\mathbf{b})}[$ V. Abs. (\%)] & $94(100,0)$ & $51(100,0)$ & $43(100,0)$ \\
\hline \multicolumn{4}{|c|}{$\chi^{2}$ Pearson $=0,026 ; p<0,872(1$ g.l. $)$} \\
\hline Outras vias [V. Abs. (\%)] & $46(100,0)$ & $27(100,0)$ & $19(100,0)$ \\
\hline Ignorada [V. Abs. (\%)] & $57(100,0)$ & $31(100,0)$ & $26(100,0)$ \\
\hline
\end{tabular}

Notas: (a) Total de mulheres que relataram categoria sexual de exposição ao vírus.

(b) Total de mulheres que relataram categoria sanguínea de exposição ao vírus.

No momento do teste, $9,6 \%$ das mulheres $(n=103)$ não sabiam que estavam sendo testadas. Dentre aquelas que sabiam, 53,1\% não receberam orientação e 6,0\% receberam orientação em grupo. Essas situações não se mostraram estatisticamente diferentes em relação à raça/cor das entrevistadas. Em relação ao momento de revelação do diagnóstico foram descritas situações não convencionais como a ausência de conversa (embora o resultado tenha sido recebido pessoalmente) e entrega do resultado para outra pessoa $(5,1 \%$ do total). A proporção de mulheres 
negras que relatou tais atitudes foi menor que a de mulheres não negras (dados não apresentados em tabelas).

Para as mulheres que souberam caracterizar o processo de aconselhamento pré e pós-testagem e que souberam relatar o tempo que demoraram a iniciar o tratamento em serviço especializado, os dados foram descritos na Tabela 12. Foi observada diferença estatística em relação à raça/cor da entrevistada no estudo das variáveis "atitude do profissional que entregou o resultado do exame" $(p<0,029)$ e "sensação despertada no momento da entrega do resultado" ( $p<0,012)$. Também foi possível observar que grande parte das mulheres procurou um serviço de saúde especializado com rapidez (79,7\% das negras e 77,7\% das não negras procuraram em menos de 1 mês), enquanto apenas $8,6 \%$ das negras e 12,1\% das não negras demoraram 10 meses ou mais. 
Tabela 12. Distribuição da população por características relacionadas ao processo de aconselhamento, segundo raça/cor. São Paulo, 2000.

\begin{tabular}{|c|c|c|c|}
\hline Variável & Total & $\frac{\text { Negra }}{(\%)}$ & $\frac{\text { Não Negra }}{(\%)}$ \\
\hline \multicolumn{4}{|l|}{ Aconselhamento pré-teste } \\
\hline Sim, individual & $378 \quad(40,9)$ & 44,2 & 37,6 \\
\hline Sim, em grupo & $56 \quad(6,0)$ & 6,7 & 5,4 \\
\hline Não & $491 \quad(53,1)$ & 49,1 & 57,0 \\
\hline \multirow[t]{2}{*}{ Total $^{(\mathbf{a})}$ [V. Abs. (\%)] } & $925(100,0)$ & $464(100,0)$ & $461(100,0)$ \\
\hline & \multicolumn{3}{|c|}{$\chi^{2}$ Pearson $=5,837 ; \mathrm{p}<0,054(2$ g.l. $)$} \\
\hline \multicolumn{4}{|c|}{$\begin{array}{l}\text { Atitude do profissional que entregou o } \\
\text { resultado do teste }\end{array}$} \\
\hline$\overline{\text { Conversou sobre } \mathrm{o}}$ assunto & $634(75,1)$ & 78,3 & 71,8 \\
\hline Não conversou sobre o assunto & $210(24,9)$ & 21,7 & 28,2 \\
\hline \multirow[t]{2}{*}{ Total $^{(\mathbf{b})}[$ V. Abs. (\%)] } & $844(100,0)$ & $433(51,3)$ & $411(100,0)$ \\
\hline & \multicolumn{3}{|c|}{$\chi^{2}$ Pearson $=4,788 ; p<0,029(1$ g.l. $)$} \\
\hline \multicolumn{4}{|c|}{$\begin{array}{l}\text { Sensação despertada no momento da } \\
\text { entrega do resultado }^{(\text {b), (c) }}\end{array}$} \\
\hline Apoio e atenção & $581 \quad(71,5)$ & 75,8 & 66,9 \\
\hline Indiferença & $127(15,6)$ & 14,2 & 17,2 \\
\hline Discriminação & $36 \quad(4,4)$ & 3,3 & 5,6 \\
\hline Crítica ou acusação & $10 \quad(1,2)$ & 1,7 & 0,7 \\
\hline Normal & $59 \quad(7,3)$ & 5,0 & 9,6 \\
\hline \multirow[t]{2}{*}{ Total [V. Abs. (\%)] } & $813(100,0)$ & $417(100,0)$ & $396(100,0)$ \\
\hline & \multicolumn{3}{|c|}{$\chi^{2}$ Pearson $=12,857 ; p<0,0,12$ (4 g.l.) } \\
\hline \multicolumn{4}{|c|}{ Tempo que demorou em procurar o } \\
\hline \multicolumn{4}{|l|}{ servico especializado (meses) } \\
\hline Menos de 1 & $827 \quad(78,7)$ & 79,7 & 77,7 \\
\hline $1-3$ & $38 \quad(3,6)$ & 4,1 & 3,1 \\
\hline $4-6$ & $(4,7)$ & 5,3 & 4,0 \\
\hline $7-9$ & $27 \quad(2,7)$ & 2,3 & 3,1 \\
\hline 10 ou mais & $109 \quad(10,3)$ & 8,6 & 12,1 \\
\hline \multirow[t]{2}{*}{ Total [V. Abs. (\%)] } & $1.051(100,0)$ & $532(100,0)$ & $519(100,0)$ \\
\hline & \multicolumn{3}{|c|}{$\chi^{2}$ Pearson $=5,543 ; p<0,236$ (4 g.l.) } \\
\hline
\end{tabular}

Notas: (a) Excluindo aquelas que não sabiam estar sendo testadas e aquelas que fizeram o teste em laboratório de análises clínicas.

(b) Excluindo aquelas que não receberam o resultado pessoalmente.

(c) Excluindo aquelas que não souberam descrever a sensação despertada pela atitude do profissional que entregou o resultado.

A nova condição de vida e de saúde apontava a necessidade de informações sobre reinfecção, terapia medicamentosa, transmissão materno-infantil e contracepção. O tipo de informação recebida é apresentado na Tabela 13. Mostraram-se estatisticamente diferentes no tocante à raça/cor das entrevistadas as 
variáveis "informação sobre terapia anti-retroviral para o bebê" $(p<0,019)$ e “informação sobre redução de danos no uso de drogas injetáveis" $(p<0,006)$.

Tabela 13. Informações recebidas em serviços especializados no tratamento/acompanhamento de pessoas vivendo com HIV/AIDS, segundo raça/cor. São Paulo, 2000.

\begin{tabular}{lccc}
\hline Informaçães Oferecidas pelo(s) & Total & Negra & Não Negra \\
\cline { 2 - 4 } Serviço(S) Especializado(S) $^{(*)}$ & V. Abs. (\%) & $\mathbf{( \% )}$ & $\mathbf{( \% )}$ \\
\hline Transmissão durante a gravidez & $801(76,1)$ & 73,8 & 78,5 \\
Transmissão durante o parto & $780(73,9)$ & 71,3 & 76,6 \\
Transmissão durante a amamentação & $816(77,2)$ & 74,8 & 79,7 \\
Terapia anti-retroviral durante a gravidez & $744(70,7)$ & 67,4 & 74,0 \\
Terapia anti-retroviral para o bebê & $682(64,8)$ & 62,6 & 67,1 \\
Prevenção de reinfecção & $910(86,7)$ & 84,8 & 88,6 \\
Prevenção em parcerias sorodiscordantes & $929(88,8)$ & 87,5 & 90,1 \\
Redução de danos no uso de drogas & & & \\
injetáveis & $409(48,6)$ & 44,0 & 53,4 \\
Terapia anti-retroviral & $997(94,9)$ & 94,1 & 95,6 \\
Método contraceptivo mais adequado & $567(56,2)$ & 56,7 & 55,7 \\
\hline
\end{tabular}

Nota: (*) Foram consideradas somente as respostas positivas para cada uma das informações citadas. As categorias não são excludentes.

\subsubsection{Vida sexual}

A maioria das mulheres relatou vida sexual ativa e uso de preservativo após o diagnóstico. Trinta e um por cento dessas mulheres afirmaram que a vida sexual ficou diferente, $28,9 \%$ relataram piora; $27,8 \%$ afirmaram que ficou igual e $12,0 \%$ afirmaram que a vida sexual melhorou. No momento da entrevista, 45,5\% das mulheres $(\mathrm{n}=486)$ não tinham parceiro sexual; 53,9\% $(\mathrm{n}=575)$ tinham parceiro fixo; e apenas $0,7 \%(n=7)$ parceiros eventuais (Tabela 14). Mais mulheres negras que não negras relataram não ter parceiros sexuais (dado não descrito em tabela). 
Tabela 14. Distribuição da população por características relacionadas à vida sexual após o diagnóstico, segundo raça/cor. São Paulo, 2000.

\begin{tabular}{|c|c|c|c|}
\hline Variável & $\begin{array}{c}\text { Total } \\
\text { V. Abs. (\%) } \\
\end{array}$ & $\begin{array}{c}\text { Negra } \\
(\%)\end{array}$ & $\begin{array}{c}\text { Não Negra } \\
(\%) \\
\end{array}$ \\
\hline \multicolumn{4}{|c|}{ Vida sexual após o diagnóstico } \\
\hline Ativa & $814 \quad(76,5)$ & 75,7 & 77,3 \\
\hline Inativa & $250 \quad(23,5)$ & 24,3 & 22,7 \\
\hline \multirow[t]{2}{*}{ Total [V. Abs. (\%)] } & $1.064(100,0)$ & $540(100,0)$ & $524(100,0)$ \\
\hline & \multicolumn{3}{|c|}{$\chi^{2}$ Pearson $=0,355 ; \mathrm{p}<0,551(1$ g.l. $)$} \\
\hline \multicolumn{4}{|c|}{$\begin{array}{l}\text { Qualidade da vida sexual após o } \\
\text { diagnóstico }\end{array}$} \\
\hline Ficou igual & $226(27,8)$ & 25,9 & 29,6 \\
\hline Piorou & $235 \quad(28,9)$ & 30,3 & 27,4 \\
\hline Melhorou & $98 \quad(12,0)$ & 11,5 & 12,6 \\
\hline Ficou diferente & $255 \quad(31,3)$ & 32,3 & 30,4 \\
\hline \multirow[t]{2}{*}{ Total $^{(\mathbf{a})}[$ V. Abs. (\%)] } & $814(100,0)$ & $409(100,0)$ & $405(100,0)$ \\
\hline & \multicolumn{3}{|c|}{$\chi^{2}$ Pearson $=2,048 ; \mathrm{p}<0,563(3$ g.l. $)$} \\
\hline \multicolumn{4}{|c|}{$\begin{array}{l}\text { Uso de preservativo masculino após o } \\
\text { diagnóstico }\end{array}$} \\
\hline Nunca & $95 \quad(11,8)$ & 14,3 & 9,4 \\
\hline Às vezes & $162(20,1)$ & 19,3 & 21,0 \\
\hline Todas às vezes & $548 \quad(68,1)$ & 66,4 & 69,6 \\
\hline \multirow[t]{2}{*}{ Total [V. Abs. (\%)] } & $805(100,0)$ & $400(100,0)$ & $405(100,0)$ \\
\hline & \multicolumn{3}{|c|}{$\chi^{2}$ Pearson $=4,631 ; \mathrm{p}<0,099(2$ g.l. $)$} \\
\hline \multicolumn{4}{|l|}{ Tipo de parceria atual } \\
\hline$\overline{\text { Estável }}$ & $575 \quad(98,8)$ & 98,6 & 99,0 \\
\hline Eventual & $7 \quad(1,2)$ & 1,4 & 1,0 \\
\hline Total $^{(\mathbf{b})}[$ V. Abs. (\%)] & $582(100,0)$ & $283(100,0)$ & $299(100,0)$ \\
\hline \multicolumn{4}{|c|}{$\chi^{2}$ Pearson $=0,206 ; p<0,650(1$ g.l. $)$} \\
\hline
\end{tabular}

Notas: (a) Mulheres que relataram vida sexual ativa após o diagnóstico.

(b) Mulheres que tinham parceiro na época da entrevista.

As características relacionadas à vida sexual com parceiro fixo foram descritas na Tabela 15. Das mulheres envolvidas em relações estáveis, 72,9\% moram com o parceiro, não existindo diferença por raça/cor. A condição sorológica do parceiro era desconhecida por $16,5 \%$ das mulheres negras e $10,5 \%$ das mulheres não negras. Algumas mulheres não haviam revelado sua condição sorológica ao parceiro $(6,4 \%)$. Embora não tenha havido significância estatística, dentre aquelas que não sabiam se o parceiro tinha tal informação, a maioria era negra. $\mathrm{O}$ uso de preservativo masculino foi relatado por $89,6 \%$ das mulheres. Para aquelas que, em alguma ocasião, solicitaram preservativo no serviço de saúde especializado $(\mathrm{n}=$ 
421), mais mulheres não negras relataram nunca ter facilidade para obtê-lo (dados não apresentados em tabelas).

Tabela 15. Distribuição da população por características relacionadas à vida sexual com parceiro fixo atual, segundo raça/cor. São Paulo, 2000.

\begin{tabular}{|c|c|c|c|}
\hline Variável & Total & $\begin{array}{c}\text { Negra } \\
(\%)\end{array}$ & $\begin{array}{c}\text { Não Negra } \\
(\%)\end{array}$ \\
\hline \multicolumn{4}{|l|}{$\underline{\text { Atividade sexual }}$} \\
\hline$\overline{\operatorname{Sim}}$ & $542(94,3)$ & 95,0 & 93,6 \\
\hline Não & $33 \quad(5,7)$ & 5,0 & 6,4 \\
\hline \multirow[t]{2}{*}{ Total [V. Abs. (\%)] } & $575(100,0)$ & $279(100,0)$ & $296(100,0)$ \\
\hline & \multicolumn{3}{|c|}{$\chi^{2}$ Pearson $=0,521 ; \mathrm{p}<0,470(1$ g.l. $)$} \\
\hline \multicolumn{4}{|l|}{ Mora com parceiro } \\
\hline Sim & $419(72,9)$ & 73,1 & 72,6 \\
\hline Não & $156(27,1)$ & 26,9 & 27,4 \\
\hline \multirow[t]{2}{*}{ Total [V. Abs. (\%)] } & $575(100,0)$ & $279(100,0)$ & $296(100,0)$ \\
\hline & \multicolumn{3}{|c|}{$\chi^{2}$ Pearson $=0,017 ; p<0,896$ (1g.1.) } \\
\hline \multicolumn{4}{|c|}{ Condição sorológica do parceiro } \\
\hline Soropositivo & $251(43,7)$ & 43,4 & 43,9 \\
\hline Soronegativo & $247(43,0)$ & 40,1 & 45,6 \\
\hline Não sabe & $77(13,4)$ & 16,5 & 10,5 \\
\hline \multirow[t]{2}{*}{ Total [V. Abs. (\%)] } & $575(100,0)$ & $279(100,0)$ & $296(100,0)$ \\
\hline & \multicolumn{3}{|c|}{$\chi^{2}$ Pearson $=4,888 ; \mathrm{p}<0,087(2$ g.l. $)$} \\
\hline \multicolumn{4}{|c|}{ Parceiro sabe que você é soropositiva } \\
\hline$\overline{\operatorname{Sim}}$ & $528(91,8)$ & 90,3 & 93,2 \\
\hline Não & $37 \quad(6,4)$ & 6,8 & 6,1 \\
\hline Não sabe ${ }^{(a)}$ & $10 \quad(1,8)$ & 2,9 & 0,7 \\
\hline \multirow[t]{2}{*}{ Total [V. Abs. (\%)] } & $575(100,0)$ & $279(100,0)$ & $296(100,0)$ \\
\hline & \multicolumn{3}{|c|}{$\chi^{2}$ Pearson $=4,219 ; \mathrm{p}<0,121(2$ g.l. $)$} \\
\hline \multicolumn{4}{|l|}{ Uso de preservativo } \\
\hline$\overline{\text { Nunca }}$ & $56(10,4)$ & 12,1 & 8,7 \\
\hline Às vezes & $117(21,6)$ & 19,3 & 23,8 \\
\hline Todas às vezes & $368(68,0)$ & 68,6 & 67,5 \\
\hline \multirow[t]{2}{*}{ Total $^{(\mathrm{b})}$ [V. Abs. (\%)] } & $541(100,0)$ & $264(100,0)$ & $277(\mathbf{1 0 0 , 0 )}$ \\
\hline & \multicolumn{3}{|c|}{$\chi^{2}$ Pearson $=2,853 ; p<0,240(2$ g.l. $)$} \\
\hline \multicolumn{4}{|c|}{$\begin{array}{l}\text { Facilidade em obter preservativo } \\
\text { masculino no serviço que é atendida }\end{array}$} \\
\hline Na maioria das vezes & $356(84,6)$ & 86,6 & 82,5 \\
\hline Às vezes & $33 \quad(7,8)$ & 6,7 & 9,0 \\
\hline Nunca & $32 \quad(7,6)$ & 6,7 & 8,5 \\
\hline \multirow[t]{2}{*}{ Total $^{(\mathrm{c})}$ [V. Abs. (\%)] } & $421(100,0)$ & $209(100,0)$ & $212(100,0)$ \\
\hline & \multicolumn{3}{|c|}{$\chi^{2}$ Pearson $=1,337 ; p<0,512(2$ g.l. $)$} \\
\hline
\end{tabular}

Notas: (a) Referente àquelas que não sabem se o parceiro tem essa informação, por nunca terem conversado sobre o assunto.

(b) Mulheres que relataram vida sexual ativa com parceiro fixo.

(c) Mulheres que relataram vida sexual ativa com parceiro fixo e que, em algum momento, buscaram obter preservativo no serviço de saúde especializado. 


\subsubsection{Serviço de saúde: acesso e acolhimento}

As mulheres relataram que, em média, demoravam 1 hora e 10 minutos no trajeto de sua casa ao serviço de saúde especializado. Setenta e oito por cento relataram depender de transporte coletivo $(82,1 \%$ das negras e $74,0 \%$ das não negras), $11,0 \%$ de transporte particular (15,3\% das não negras e 6,7\% das negras). As demais utilizavam ambulância; vários meios de transporte; ou se dirigiam ao serviço de saúde a pé. O tipo de transporte utilizado mostrou-se estatisticamente diferente em relação à raça/cor da entrevistada $\left[\chi^{2}\right.$ Pearson $=25,506 ; \mathrm{p}<0,000$ (4g.1)]. Para aquelas que afirmaram depender de transporte coletivo, 65,9\% tinham facilidade em conseguir transporte (dados não apresentados em tabelas).

Os dados da Tabela 16 mostram que poucas mulheres relataram atendimento nutricional, por outro médico que não infectologista ou ginecologista, bem como atendimento odontológico ou psicológico. Pouco mais da metade já havia sido atendida por assistentes sociais ou por enfermeiros e $62,7 \%$ já haviam passado em consulta ginecológica. A diferença na distribuição entre negras e não negras foi estatisticamente significante para as variáveis "ter sido atendida por médico ginecologista" $\left[\chi^{2}\right.$ Pearson $=4,707 ; \mathrm{p}<0,030$ (1g.1.)]; "ter sido atendida por nutricionista" $\left[\chi^{2}\right.$ Pearson $=9,706 ; \mathrm{p}<0,002$ (1g.1.) $]$; e "ter sido atendida por outro médico que não infectologista ou ginecologista" $\left[\chi^{2}\right.$ Pearson $=8,218 ; \mathrm{p}<0,004$ (1g.1.)]. Na mesma tabela também são apresentados outros dados sobre a relação das mulheres com o serviço de saúde especializado e com os profissionais que neles atuam, tais como a ocorrência de situações inadequadas ou ainda a facilidade em obter outros remédios, além do coquetel, nesse serviço de saúde. 
Tabela 16. Características do cuidado recebido no serviço de saúde especializado, segundo raça/cor. São Paulo, 2000.

\begin{tabular}{|c|c|c|c|}
\hline Variável & Total & $\begin{array}{c}\text { Negra } \\
(\%) \\
\end{array}$ & $\begin{array}{c}\text { Não Negra } \\
(\%) \\
\end{array}$ \\
\hline Profissional(is) por quem já foi atendida $^{\text {(a) }}$ & & & \\
\hline Enfermeira(o) & $608(57,1)$ & 57,3 & 57,0 \\
\hline Psicóloga $(\mathrm{o})$ & $441(41,5)$ & 41,7 & 41,2 \\
\hline Assistente social & $584(54,9)$ & 55,9 & 53,8 \\
\hline Ginecologista & $667(62,7)$ & 65,9 & 59,4 \\
\hline Dentista & $415(39,1)$ & 37,0 & 41,2 \\
\hline Nutricionista & $121(11,4)$ & 8,4 & 14,5 \\
\hline Outro médico que não infectologista & $238(22,5)$ & 18,9 & 26,2 \\
\hline Outro profissional & $39 \quad(3,7)$ & 3,2 & 4,2 \\
\hline \multicolumn{4}{|l|}{$\frac{\text { Situacões inadequadas vivenciadas no }}{\text { servico de saúde }^{(\mathbf{a})}}$} \\
\hline Ser atendida sem ser olhada & $161(15,1)$ & 14,0 & 16,2 \\
\hline $\begin{array}{l}\text { Ser tratada com discriminação ou } \\
\text { preconceito }\end{array}$ & $71 \quad(6,7)$ & 6,5 & 6,8 \\
\hline $\begin{array}{l}\text { Sentir dor ou desconforto físico por erro do } \\
\text { serviço }\end{array}$ & $94(8,8)$ & 7,2 & 10,5 \\
\hline Sofrer humilhação & $75 \quad(7,0)$ & 6,9 & 7,2 \\
\hline \multicolumn{4}{|l|}{$\frac{\text { Facilidade em obter outros remédios além }}{\text { do coquetel }^{(b)}}$} \\
\hline$\overline{\mathrm{Na} \text { maioria }}$ das vezes & $664(69,0)$ & 68,7 & 69,4 \\
\hline Às vezes & $223(23,2)$ & 22,8 & 23,5 \\
\hline Nunca & $75(7,8)$ & 8,5 & 7,1 \\
\hline \multirow[t]{2}{*}{ Total [V. Abs. (\%)] } & $962(100,0)$ & $485(100,0)$ & $477(100,0)$ \\
\hline & \multicolumn{3}{|c|}{$\chi^{2}$ Pearson $=0,597 ; p<0,742(2$ g.l. $)$} \\
\hline
\end{tabular}

Notas: (a) Foram consideradas somente as respostas positivas para cada uma das informações citadas, sendo possíveis múltiplas respostas.

(b) Mulheres que, em algum momento, buscaram obter outros remédios, que não o coquetel, no serviço de saúde especializado.

Embora grande parte das mulheres tivesse facilidade para entender o que o profissional dizia e facilidade para tirar suas dúvidas, a facilidade em falar sobre a vida sexual foi menos freqüente, fosse na relação com o infectologista ou com o ginecologista. Foi observada diferença estatisticamente significante entre facilidade em entender o que o infectologista dizia e facilidade em falar com o infectologista ou com o ginecologista sobre a vida sexual e raça/cor. As mulheres negras, em menor número, tiveram facilidade de comunicação (Tabelas 17 e 18). A (im)possibilidade de comunicação com o psicólogo foi semelhante para negras e não negras, com destaque para a não facilidade em falar sobre sua vida sexual (dados não apresentados). 
Tabela 17. Comunicação com o infectologista do serviço especializado, segundo raça/cor. São Paulo, 2000.

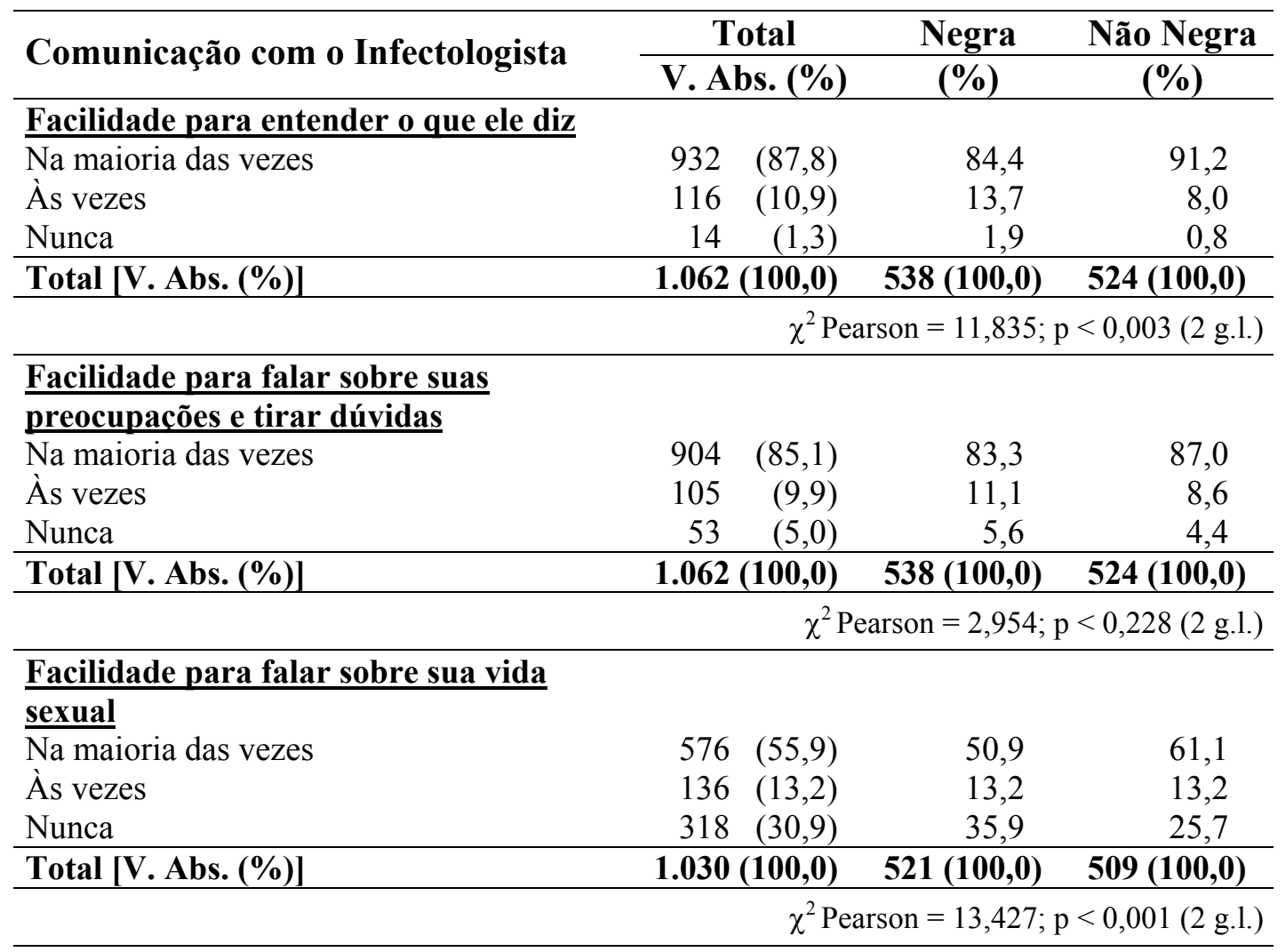


Tabela 18. Comunicação com o ginecologista do serviço especializado, segundo raça/cor. São Paulo, 2000.

\begin{tabular}{|c|c|c|c|}
\hline Comunicação com o Ginecologista & $\begin{array}{c}\text { Total } \\
\text { V. Abs. }(\%)\end{array}$ & $\frac{\text { Negra }}{(\%)}$ & $\frac{\text { Não Negra }}{(\%)}$ \\
\hline \multicolumn{4}{|l|}{ Facilidade para entender o que ele diz } \\
\hline Na maioria das vezes & $515(81,1)$ & 78,3 & 84,3 \\
\hline Às vezes & $100(15,7)$ & 18,5 & 12,7 \\
\hline Nunca & $20 \quad(3,1)$ & 3,3 & 3,0 \\
\hline \multirow[t]{2}{*}{ Total [V. Abs. (\%)] } & $635(100,0)$ & $336(100,0)$ & $299(100,0)$ \\
\hline & \multicolumn{3}{|c|}{$\chi^{2}$ Pearson $=4,053 ; p<0,132(2$ g.l. $)$} \\
\hline \multicolumn{4}{|l|}{ Facilidade para falar sobre suas } \\
\hline \multicolumn{4}{|l|}{ preocupacões e tirar dúvidas } \\
\hline Na maioria das vezes & $429 \quad(67,7)$ & 65,0 & 70,7 \\
\hline Às vezes & $(18,6)$ & 20,8 & 16,2 \\
\hline Nunca & $(13,7)$ & 14,2 & 13,1 \\
\hline \multirow[t]{2}{*}{ Total [V. Abs. (\%)] } & $634(100,0)$ & $337(100,0)$ & $297(100,0)$ \\
\hline & \multicolumn{3}{|c|}{$\chi^{2}$ Pearson $=2,709 ; \mathrm{p}<0,258$ (2 g.l. } \\
\hline \multicolumn{4}{|l|}{ Facilidade para falar sobre sua vida } \\
\hline \multicolumn{4}{|l|}{ sexual } \\
\hline Na maioria das vezes & $320 \quad(51,2)$ & 44,7 & 58,6 \\
\hline Às vezes & $122(19,6)$ & 20,4 & 18,5 \\
\hline Nunca & $183 \quad(29,3)$ & 34,9 & 22,9 \\
\hline \multirow[t]{2}{*}{ Total [V. Abs. (\%)] } & $625(100,0)$ & $333(100,0)$ & $292(100,0)$ \\
\hline & \multicolumn{3}{|c|}{$\chi^{2}$ Pearson $=13,608 ; p<0,001(2$ g.l. $)$} \\
\hline
\end{tabular}

\subsubsection{Relação com o serviço e cuidados com a saúde}

Foi possível observar que muitas mulheres relataram freqüência constante de ida ao serviço e poucas faltas $(79,1 \%$ relataram ir, no mínimo, uma vez por mês e apenas 2,2\% afirmou faltar em mais da metade das consultas agendadas); entretanto, $83,1 \%$ daquelas que tinham indicação de terapia medicamentosa envolvendo antiretrovirais, confirmaram algum tipo de falha na ingestão dos mesmos (dados não apresentados em tabelas). Nenhuma das variáveis mostrou-se estatisticamente diferente em relação à raça/cor das entrevistadas.

Das mulheres que já haviam feito o exame $(n=1008), 48,0 \%$ não souberam informar o último resultado; contudo, entre aquelas que detinham tal informação foi interessante observar que 21,8\% haviam apresentado carga viral indetectável (dados não apresentados em tabelas).

Daquelas que já haviam feito o exame para contagem de células TCD4 (n = 1.043), 41,8\% não souberam informar o último resultado (informações não apresentadas em tabelas). Entre as mulheres que fizeram o exame e que sabiam o 
resultado foi importante observar que 56,3\% apresentavam mais de 350 células TCD4 por $\mathrm{mm}^{3}$ (a condição clínica das mulheres, medida aqui pelo número de células TCD4 por $\mathrm{mm}^{3}$ de sangue circulante, não se mostrou estatisticamente diferente segundo raça/cor das entrevistadas).

De acordo com os dados descritos na Tabela 19 foi possível observar que, independentemente de terem ou não realizado os exames, muitas não souberam dizer o significado e a finalidade dos mesmos (39,4\% para o exame de carga viral e $49,1 \%$ para o exame de CD4). Outro dado importante é que o comportamento das variáveis sabe o significado do exame de CD4 e sabe o significado do exame de carga viral mostrou-se estatisticamente diferente a depender da raça/cor das mulheres entrevistadas $(\mathrm{p}<0,000)$ : as mulheres negras deixaram de ter tal informação com maior freqüência.

Tabela 19. Relação com o serviço e cuidados com a saúde, segundo raça/cor. São Paulo, 2000.

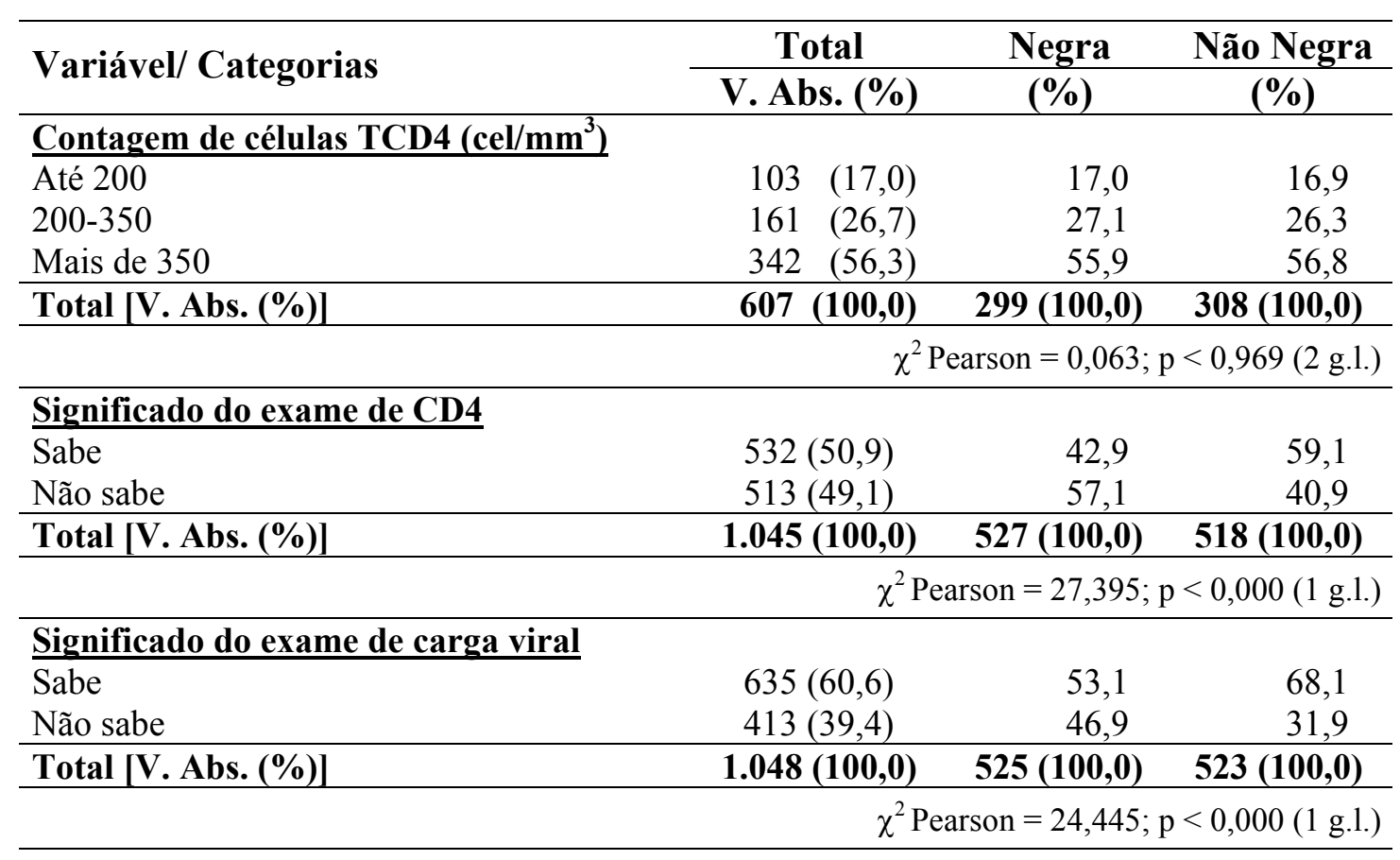




\subsubsection{Síntese dos resultados da análise univariada}

Mostraram-se estatisticamente diferentes em relação à raça/cor as variáveis:

- nível de escolaridade;

- número de cômodos;

- condições de moradia: categorias número de cômodos em casa de tijolos e número de cômodos em apartamento;

- renda individual mensal;

- renda familiar per capita mensal;

- número de pessoas que cuida;

- categoria sexual de exposição ao HIV;

- atitude do profissional que entregou o resultado do teste;

- sensação despertada no momento da entrega do resultado;

- informação sobre terapia anti-retroviral para o recém-nascido;

- informação sobre redução de danos no uso de drogas injetáveis;

- tipo de transporte utilizado para acessar o serviço de saúde especializado;

- atendimento profissional: categorias ginecologista, nutricionista e outro médico que não infectologista ou ginecologista;

- facilidade em entender o que o infectologista diz;

- facilidade em falar sobre sua vida sexual com o infectologista;

- facilidade em falar sobre sua vida sexual com o ginecologista;

- significado do exame de CD4;

- significado do exame de carga viral.

As mulheres negras estudadas eram menos escolarizadas que as não negras, moravam em casas ou apartamentos com menor número de cômodos, apresentavam os menores rendimentos individuais e familiares e eram responsáveis pelo cuidado de um número maior de pessoas.

No tocante à exposição sexual ao HIV, entre as mulheres não negras foi maior a proporção de infecção via relação sexual desprotegida com parceiros pouco conhecidos ou UDIs; em contrapartida entre as negras foi maior o desconhecimento da via de infecção do parceiro, a possibilidade de ele ter sido infectado por outro homem ou por outras relações heterossexuais. 
As mulheres negras relataram com maior freqüência a ocorrência de uma conversa com o profissional que lhe entregou o resultado do teste, da mesma forma o fizeram em relação ao despertar de uma sensação de apoio e atenção naquele momento.

No que diz respeito à informação oferecida pelo serviço de saúde especializado, mais mulheres não negras deixaram de ser informadas sobre a existência de terapia anti-retroviral para o recém-nascido e sobre a redução de danos no uso de drogas injetáveis.

As mulheres negras passaram por consultas ginecológicas com mais freqüência; contudo, atenção nutricional e médica de outra especialidade que não infectologia ou ginecologia, foram mais relatadas por mulheres não negras. Em relação à comunicação com o médico infectologista e ginecologista, as negras apresentaram maior dificuldade em entender o que o infectologista dizia e em conversar sobre sua vida sexual com ambos os especialistas. Da mesma forma, esse grupo foi o que menos soube informar o significado dos exames de CD4 e carga viral.

Embora não tenha sido identificada diferença estatisticamente significante no estudo das demais variáveis é importante ressaltar que: todas mulheres moradoras de rua ou de casas de apoio eram negras; a proporção de mulheres não negras foi maior no tocante à contribuição mensal para o orçamento familiar menor ou igual a $50 \%$, diagnóstico de soropositividade recebido há mais tempo, tomada de decisão para a realização do teste por precaução, em detrimento das mulheres negras que se sobressaíram dentre aquelas que decidiram fazer o teste por acreditar na possibilidade de infecção ou porque se relacionavam com parceiro sabidamente soropositivo.

As mulheres não negras também relataram com maior freqüência a inadequação do cuidado nos momentos anterior e posterior ao teste (ausência de conversa/aconselhamento pré-teste, atendimento sem a devida atenção, sensação de dor ou desconforto físico provocado por erro do serviço, tratamento com humilhação). 


\subsection{Análise Multivariada Utilizando a Técnica CHAID}

Nesta etapa da análise foram estudadas as variáveis-resposta: "razão da testagem"; "aconselhamento pré-teste (conversa)"; "atitude do profissional que entregou o resultado do teste"; "sensação despertada no momento da entrega do resultado"; "tempo que demorou em procurar o serviço de saúde especializado"; "uso de preservativo após o diagnóstico"; "facilidade em obter outros remédios além do coquetel"; "facilidade em entender o que o infectologista diz"; "facilidade em falar sobre a vida sexual com o infectologista"; "facilidade em entender o que o ginecologista diz"; "facilidade em falar da vida sexual com o ginecologista", "significado do exame CD4" e "significado do exame de carga viral". Em cada um dos modelos processados, separadamente, para mulheres negras e não negras, foi incluído um grupo de variáveis explicativas conforme descrito a seguir.

\subsubsection{Estudo das variáveis-resposta relacionadas ao cuidado anterior e, imediatamente, posterior à testagem}

Para o estudo do objeto "razão da testagem" foram consideradas as seguintes variáveis independentes:

- faixa etária;

- nível de escolaridade;

- renda individual mensal;

- renda familiar per capita mensal;

- contribuição individual para a renda familiar;

- tempo de infecção diagnosticada;

- local onde realizou o teste;

- percepção de risco;

- faixa etária no momento do diagnóstico;

- idade da iniciação sexual;

- número de parceiros sexuais durante a vida.

Para o grupo de mulheres negras o único fator que apresentou significância estatística foi "percepção de risco", sendo o conjunto de mulheres dividido em 2 ramificações: percepção sim; percepção não, conforme descrito na Figura 2.

Embora nos 2 ramos mais da metade das mulheres tenha realizado o teste por solicitação do serviço de saúde, entre as mulheres negras que se percebiam em risco 
$(\mathrm{n}=181)$, a decisão em realizar o teste foi proporcionalmente maior que entre aquelas que não se percebiam em risco (24,31\% versus $13,57 \%)$. Também se deve destacar que, ainda que as proporções de mulheres na categoria "teste solicitado pelo serviço de saúde" tenham sido semelhantes $(62,05 \%$ versus $59,12 \%)$, os números absolutos aos quais elas se referem são muito diferentes: $n=224$ entre aquelas que negavam o risco e $\mathrm{n}=107$ entre aquelas que admitiam o risco.

Como no outro grupo, no modelo aplicado ao conjunto de mulheres não negras, foi preditora apenas a variável "percepção de risco" (Figura 3). Para as mulheres não negras, a não atribuição de risco de infecção pelo HIV antes do diagnóstico também esteve mais relacionada à solicitação do teste pelo serviço de saúde (ramificação 1). As mulheres que se perceberam em risco relataram, com mais freqüência, a tomada de decisão em realizar o teste $(35,75 \%$ versus $16,43 \%)$. 
Figura 2. Fatores estatisticamente relacionados à razão da testagem para mulheres negras vivendo com HIV/AIDS. São Paulo, 2000.

razão da testagem

\begin{tabular}{|c|c|c|c|}
\hline \multicolumn{4}{|c|}{ Node 0} \\
\hline & Category & $\%$ & $\mathrm{n}$ \\
\hline$\square$ & solicitação do serviço & 61,07 & 331 \\
\hline a & decisão própria & 17,16 & 93 \\
\hline $\mathbf{\square}$ & outras razões conhecidas & 10,15 & 55 \\
\hline 口 & outras razões desconhecidas & 11,62 & 63 \\
\hline & Total & $(100,00)$ & 542 \\
\hline
\end{tabular}

percepção de risco

Adj. $P$-value $=0,0198$, Chi-square $=12,2410, \mathrm{df}=3$

\begin{tabular}{|c|c|c|c|c|c|c|c|}
\hline \multicolumn{4}{|c|}{ não,<missing > } & \multicolumn{4}{|c|}{$\operatorname{sim}$} \\
\hline \multicolumn{4}{|c|}{ Node 1} & \multicolumn{4}{|c|}{ Node 2} \\
\hline & Category & $\%$ & $\mathrm{n}$ & & Category & $\%$ & $\mathrm{n}$ \\
\hline a & solicitação do serviço & $62,05 \quad 22$ & 224 & $\square$ & solicitação do serviço & 59,12 & 107 \\
\hline$\square$ & decisão própria & $13,57 \quad 4$ & 49 & - & decisão própria & 24,31 & 44 \\
\hline [ & outras razões conhecidas & 11,91 & 43 & [ & outras razões conhecidas & 6,63 & 12 \\
\hline [ & outras razões desconhecidas & 12,47 & 45 & [ & outras razões desconhecidas & 9,94 & 18 \\
\hline & Total & $(66,61) 36$ & 361 & & Total & $(33,39)$ & 181 \\
\hline
\end{tabular}


Figura 3. Fatores estatisticamente relacionados à razão da testagem para mulheres não negras vivendo com HIV/AIDS. São Paulo, 2000.

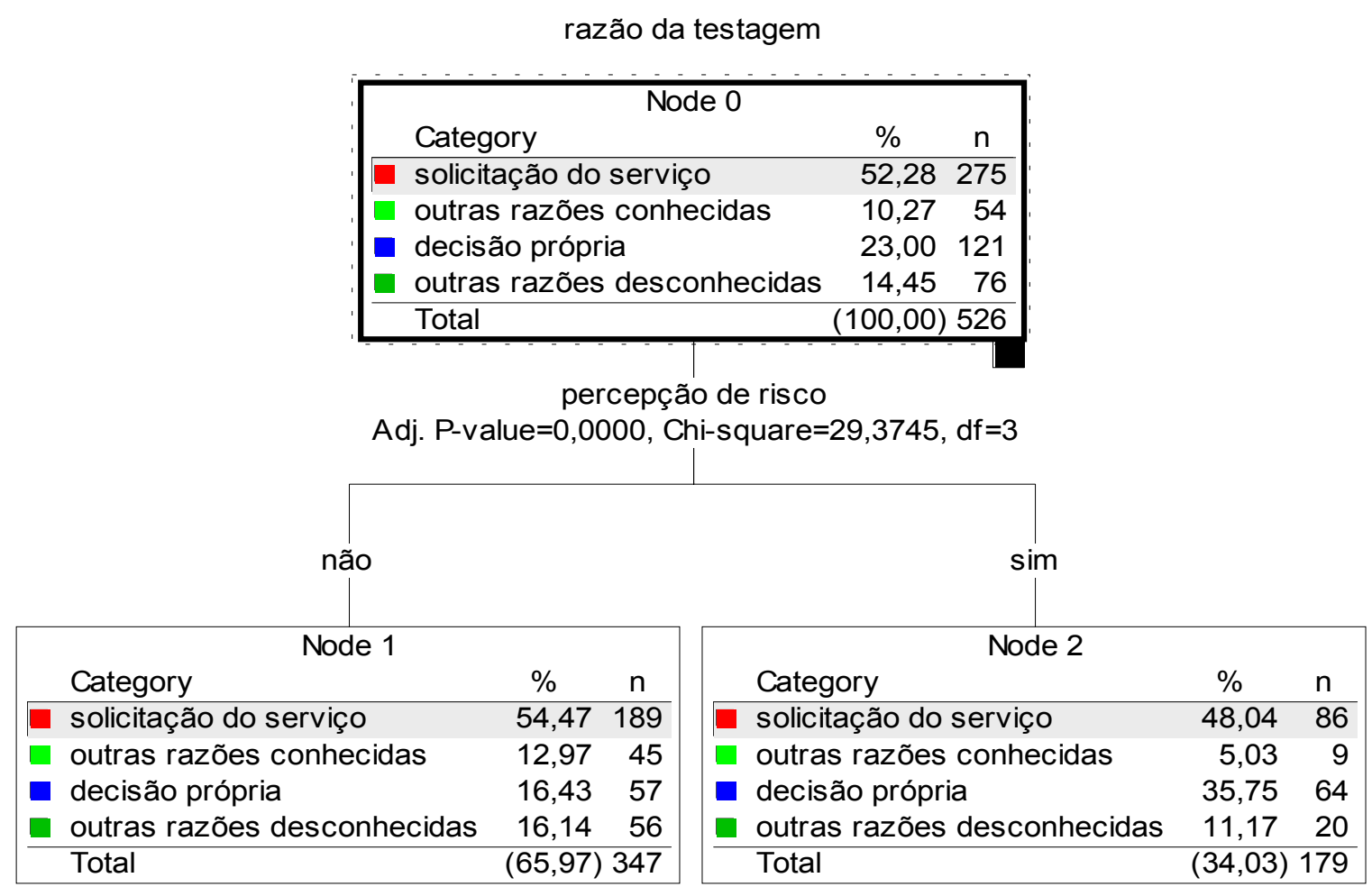


O modelo aplicado ao estudo da variável dependente "aconselhamento préteste (conversa)", conversa essa anterior à testagem, levou em consideração os predicados:

- faixa etária;

- nível de escolaridade;

- renda individual mensal;

- renda familiar per capita mensal;

- contribuição individual para a renda familiar;

- tempo de infecção diagnosticada;

- local onde realizou o teste;

- percepção de risco;

- faixa etária no momento do diagnóstico;

- idade da iniciação sexual;

- número de parceiros sexuais durante a vida;

- razão da testagem.

Na Figura 4 é apresentado o resultado da análise para o conjunto de mulheres negras. O conjunto de dados foi dividido de acordo com o predicado local da testagem. No subconjunto 1 foram agregadas as mulheres testadas em Unidade Básica de Saúde (UBS); no subconjunto 2, as mulheres testadas em hospital, laboratório de análises clínicas, banco de sangue ou de leite e maternidade; e, no subconjunto 3, ficaram as mulheres testadas em serviço especializado, COAS, aquelas que não especificaram o local onde o teste foi realizado e aquelas que não quiseram ou souberam dar a informação. Mais da metade das mulheres que compunham a ramificação 2 não receberam orientação no período anterior à testagem e $14,24 \%$ não sabiam que estavam sendo testadas. Para aquelas atendidas na UBS (ramificação 1), parcela significativa também deixou de receber orientação (44,64\%); contudo, apenas $8,04 \%$ não sabiam do teste. Nos serviços especializados e COAS, as mulheres tiveram mais oportunidades de aconselhamento $(54,37 \%$ receberam orientação); entretanto, cabe ressaltar que as proporções de mulheres que deixaram de ser orientadas ou que receberam orientação em grupo ainda se mantiveram altas $-22,33 \%$. 
Figura 4. Fatores estatisticamente relacionados ao aconselhamento pré-teste oferecido às mulheres negras vivendo com HIV/AIDS. São Paulo, 2000.

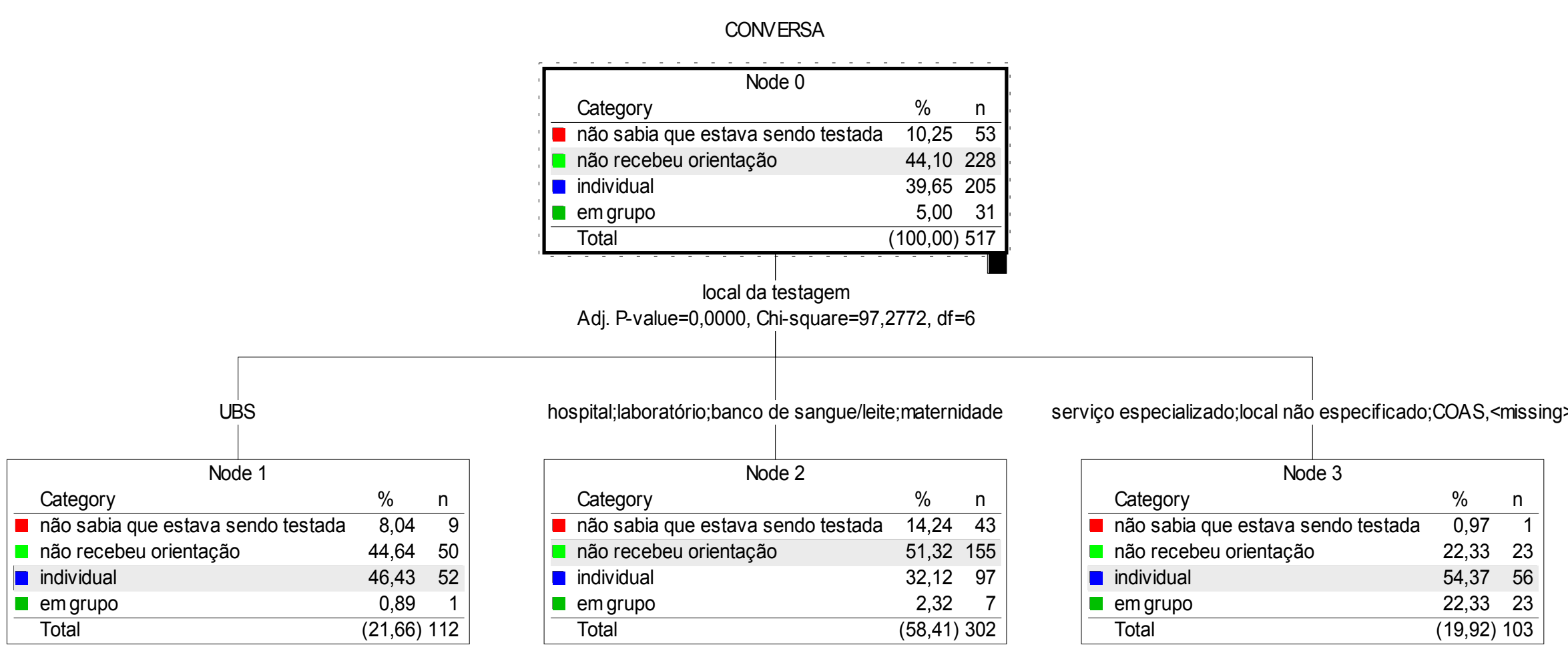


A árvore gerada no grupo de mulheres não negras (Figura 5) também apresenta a variável "local da testagem" como único fator preditor. A classificação dos elementos do grupo foi distinta daquela apresentada na Figura 4, pois, para o novo conjunto, derivaram 4 ramificações compostas por: 1. mulheres não negras realizaram o teste em hospital, maternidade ou em local não especificado $(n=226)$; 2. mulheres não negras que fizeram o teste em UBS $(n=85) ; 3$. mulheres não negras que fizeram o teste em serviço especializado, COAS ou que não deram tal informação ( $\mathrm{n}=78)$; 4. mulheres não negras que realizaram o teste em laboratório de análises clínicas, banco de sangue ou de leite $(n=122)$. No ramo 1 foi observada a maior proporção de mulheres que não sabiam que estavam sendo testadas $(17,26 \%)$, em outro extremo, no ramo 4 estava a maior proporção de mulheres que deixaram de receber orientação no momento anterior ao teste $(75,41 \%)$, situação alarmante também foi observada entre aquelas que realizaram o procedimento em UBS (ramo 2) $-54,12 \%$ e entre aquelas que o fizeram em hospital, maternidade, local não especificado (ramo 1) - 49,56\%. A conversa individual foi oferecida a $61,54 \%$ das mulheres do ramo $3 ; 40,0 \%$ das mulheres do ramo $2 ; 30,53 \%$ do ramo 1 e a $18,03 \%$ daquelas agrupadas no ramo 4. 
Figura 5. Fatores estatisticamente relacionados ao aconselhamento pré-teste oferecido às mulheres não negras vivendo com HIV/AIDS.

São Paulo, 2000.

\section{CONVERSA}

\begin{tabular}{|lrr|}
\hline \multicolumn{3}{|c}{ Node 0} \\
\hline Category & $\%$ & $\mathrm{n}$ \\
\hline individual & 33,86 & 173 \\
\hline não recebeu orientação & 51,47 & 263 \\
não sabia que estava sendo testada & 9,78 & 50 \\
em grupo & 4,89 & 25 \\
\hline Total & $(100,00)$ & 511 \\
\hline
\end{tabular}

local da testagem

Adj. $P$-value $=0,0000$, Chi-square $=131,1522, \mathrm{df}=9$

hospital;maternid de;local não especificado

\begin{tabular}{|lrr|}
\hline \multicolumn{1}{|c}{ Node 1 } & \multicolumn{1}{c|}{$\%$} & \multicolumn{1}{c|}{ n } \\
\hline Category & 30,53 & 69 \\
\hline individual & 49,56 & 112 \\
não recebeu orientação & 17,26 & 39 \\
não sabia que estava sendo testada & 2,65 & 6 \\
\hline em grupo & $(44,23)$ & 226 \\
\hline Total & & \\
\hline
\end{tabular}

UBS

\begin{tabular}{|lrr|}
\hline \multicolumn{1}{|c}{ Node 2 } & \multicolumn{1}{c|}{ \% } & \multicolumn{1}{c}{ Category } \\
\hline individual & 40,00 & 34 \\
não recebeu orientação & 54,12 & 46 \\
não sabia que estava sendo testada & 3,53 & 3 \\
em grupo & 2,35 & 2 \\
\hline Total & $(16,63)$ & 85 \\
\hline
\end{tabular}

serviço especializado;COAS,<missing>

\begin{tabular}{|lrr|}
\hline \multicolumn{1}{|c}{ Node 3 } & \multicolumn{1}{c|}{$\%$} & \multicolumn{1}{c|}{. } \\
\hline Category & 61,54 & 48 \\
\hline individual & 16,67 & 13 \\
não recebeu orientação & 1,28 & 1 \\
não sabia que estava sendo testada & 20,51 & 16 \\
\hline em grupo & $(15,26)$ & 78 \\
\hline Total & & \\
\hline
\end{tabular}

laboratório;banco de sangue/leite

\begin{tabular}{|lrr|}
\hline \multicolumn{1}{|c}{ Node 4 } & \multicolumn{1}{c|}{ Category } & \multicolumn{1}{l|}{ n } \\
\hline individual & 18,03 & 22 \\
não recebeu orientação & 75,41 & 92 \\
não sabia que estava sendo testada & 5,74 & 7 \\
em grupo & 0,82 & 1 \\
\hline Total & $(23,87)$ & 122 \\
\hline
\end{tabular}


Para o estudo da variável dependente "atitude do profissional que entregou o resultado do teste" foram consideradas as seguintes variáveis:

- faixa etária;

- nível de escolaridade;

- renda individual mensal;

- renda familiar per capita mensal;

- contribuição individual para a renda familiar;

- tempo de infecção diagnosticada;

- local onde realizou o teste;

- percepção de risco;

- faixa etária no momento do diagnóstico;

- idade da iniciação sexual;

- número de parceiros sexuais durante a vida;

- razão da testagem;

- aconselhamento pré-teste;

- categoria de exposição.

Para o conjunto das mulheres negras, apresentaram-se estatisticamente relevantes os fatores "aconselhamento pré-teste (conversa)" e "percepção de risco", como descrito na Figura 6. Nesse modelo foram produzidas 4 ramificações, uma que agrupava as mulheres que receberam orientação no momento anterior ao teste (ramo 2) e outras duas derivadas do ramo 1 (mulheres que não sabiam que estavam sendo testadas ou que não receberam orientação). Dentre essas mulheres do ramo 1 foram agrupadas aquelas que não se percebiam em risco no momento anterior ao teste (ramo 3 ) e aquelas que se percebiam em risco (ramo 4).

Para as mulheres do ramo 2, prevaleceu a atitude de orientação a respeito do assunto, por parte do profissional que entregou o resultado $(92,86 \%)$. Para as mulheres dos ramos 3 e 4, embora mais da metade tenha conversado sobre o assunto com o profissional, chama a atenção o fato de que, entre aquelas que anteriormente não se percebiam em risco, a possibilidade de não conversar foi maior que entre aquelas que se percebiam em risco (39,87\% num universo de 153 mulheres versus $25,71 \%$ num universo de 70 ). 
Figura 6. Fatores estatisticamente relacionados à atitude do profissional que entregou o resultado do teste às mulheres negras vivendo com HIV/AIDS. São Paulo, 2000.

atitude do profissional que entregou o resultado pessoalmente

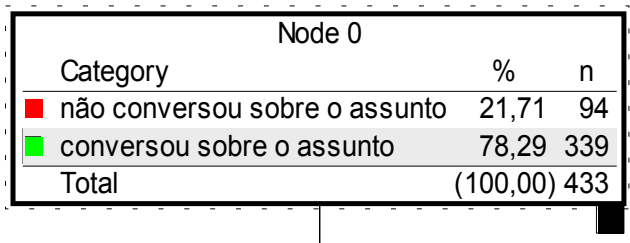

CONVERSA

Adj. P-value $=0,0000$, Chi-square $=50,9026, d f=1$

não sabia que estava sendo testada;não recebeu orientação,<missing>

\begin{tabular}{|lccc|}
\hline Category & Node 1 & $\%$ & \multicolumn{1}{c|}{$\mathrm{n}$} \\
\hline não conversou sobre o assunto & 35,43 & 79 \\
\hline conversou sobre o assunto & 64,57 & 144 \\
\hline Total & $(51,50)$ & 223 \\
\hline
\end{tabular}

percepção de risco

Adj. P-value $=0,0403$, Chi-square $=4,2065, \mathrm{df}=1$ individual;em grupo

\begin{tabular}{|c|c|c|c|}
\hline \multicolumn{4}{|c|}{ Node 2} \\
\hline & Category & $\%$ & $\mathrm{n}$ \\
\hline ( & não conversou sobre o assunto & 7,14 & 15 \\
\hline$\square$ & conversou sobre o assunto & 92,86 & 195 \\
\hline & Total & $(48,50)$ & 210 \\
\hline
\end{tabular}

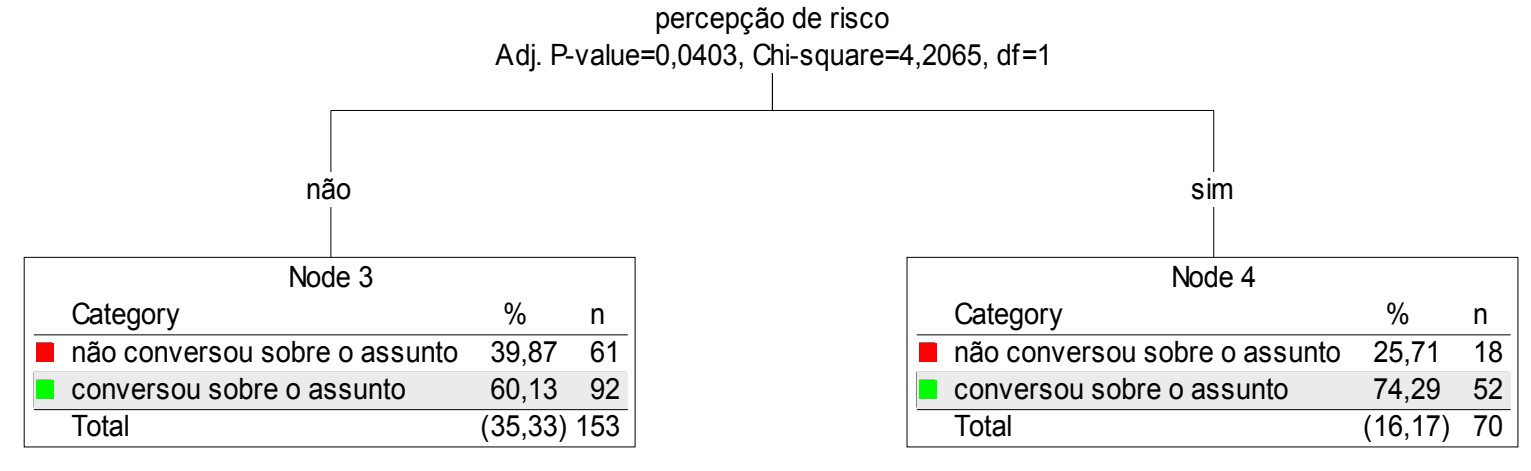


Para as mulheres não negras, o objeto sofreu influência exclusiva da variável independente "aconselhamento pré-teste (conversa)" conforme descrito na Figura 7. Todavia houvesse predição de apenas uma variável, é importante destacar a relevância da necessidade da conversa anterior à testagem e da continuidade da orientação, pois, enquanto no ramo 1 (mulheres que receberam aconselhamento antes, individual ou coletivamente), essas mulheres também o receberam no momento do diagnóstico (90,64\%); no ramo 2 (mulheres que não sabiam estar sendo testadas ou que não haviam sido orientadas), a porcentagem caiu para 58,33\%.

Figura 7. Fatores estatisticamente relacionados à atitude do profissional que entregou o resultado do teste às mulheres não negras vivendo com HIV/AIDS.

São Paulo, 2000.

atitude do profissional que entregou o resultado pessoalmente

\begin{tabular}{|lrc|}
\hline Category & Node 0 & \\
\hline não conversou sobre o assunto & 28,22 & 116 \\
\hline conversou sobre o assunto & 71,78 & 295 \\
\hline Total & $(100,00)$ & 411 \\
\hline
\end{tabular}

CONVERSA

Adj. P-value $=0,0000$, Chi-square $=51,4567, \mathrm{df}=1$

\begin{tabular}{|c|c|c|c|}
\hline \multicolumn{4}{|c|}{ individual;em grupo,<missing> } \\
\hline \multicolumn{4}{|c|}{ Node 1} \\
\hline & Category & $\%$ & $\mathrm{n}$ \\
\hline 口 & não conversou sobre o assunto & 9,36 & 16 \\
\hline 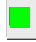 & conversou sobre o assunto & 90,64 & 155 \\
\hline & Total & $(41,61)$ & 171 \\
\hline
\end{tabular}

não recebeu orientação;não sabia que estava sendo testada

\begin{tabular}{|lccc|}
\hline Node 2 & & \\
Category & $\%$ & $\mathrm{n}$ \\
\hline não conversou sobre o assunto & 41,67 & 100 \\
\hline conversou sobre o assunto & 58,33 & 140 \\
\hline Total & $(58,39)$ & 240 \\
\hline
\end{tabular}




\subsubsection{Estudo das variáveis-resposta relacionadas às sensações e atitudes individuais após o diagnóstico de soropositividade para o HIV}

A variável "sensação despertada no momento da entrega do resultado" foi analisada segundo os seguintes fatores:

- faixa etária;

- nível de escolaridade;

- renda individual mensal;

- renda familiar per capita mensal;

- contribuição individual para a renda familiar;

- tempo de infecção diagnosticada;

- local onde realizou o teste;

- percepção de risco;

- faixa etária no momento do diagnóstico;

- idade da iniciação sexual;

- número de parceiros sexuais durante a vida;

- razão da testagem;

- atitude do profissional que entregou o resultado do teste.

Para as mulheres negras, a variável dependente sofreu influência estatisticamente significante dos predicados "atitude do profissional que lhe revelou o diagnóstico" e "via de exposição ao vírus" (Figura 8). Foram gerados 5 subconjuntos: 1. composto por mulheres negras que não conversaram com o profissional sobre o resultado do teste $(n=89)$; 2 . composto por mulheres negras que conversaram sobre o assunto $(n=328)$; 3 . composto por aquelas que não quiseram ou souberam descrever a atitude do profissional $(n=63)$. Do subgrupo 2 derivaram o segmento 4 (mulheres negras que estiveram sexualmente expostas ao vírus $-\mathrm{n}=$ 263) e o segmento 5 (mulheres negras que ignoravam sua via de infecção, que não a haviam descrito ou que se infectaram pela via sangüínea $-n=65$ ).

No subgrupo 1, a falta de conversa fez com que prevalecesse entre elas a sensação de indiferença $(41,57 \%)$. Curiosamente, entre aquelas que não souberam ou quiseram descrever a atitude do profissional (subgrupo 3), as maiores proporções foram atribuídas às sensações de apoio e atenção (39,68\%) e normalidade (34,92\%). Entre aquelas que conversaram sobre o resultado do teste com o profissional e que se expuseram ao vírus pela via sexual, outras sensações que não apoio e atenção 
tiveram pouca representatividade $(8,75 \%)$. O quadro foi diferente para as demais: $10,77 \%$ sentiram-se tratadas com indiferença e 9,24\% sentiram-se tratadas com discriminação, crítica ou acusação.

As mulheres não negras foram classificadas, única e exclusivamente, de acordo com a variável "atitude do profissional que entregou o resultado do teste" (Figura 9). Dessa classificação surgiram três subgrupos: 1. composto por aquelas com quem o profissional não conversou ao entregar o resultado $(\mathrm{n}=110) ; 2$. composto por mulheres com as quais o profissional conversou $(\mathrm{n}=286)$ e o 3 . composto por mulheres que não souberam ou quiseram descrever a atitude do profissional $(\mathrm{n}=66)$.

Na ramificação 1 predominou a sensação de indiferença $(43,64 \%)$, seguida das sensações "normal" (22,73\%) e apoio/atenção (20,00\%). Mais uma vez ficou nítido a importância da continuidade do processo de aconselhamento, dado que entre as não negras que o receberam no momento anterior à testagem a sensação de apoio/atenção prevaleceu (84,97\%); entretanto, ainda nesse grupo 6,99\% das mulheres referiram indiferença e 3,50\% discriminação. No subgrupo 3, a sensação de apoio e atenção também foi mais freqüentemente relatada, mas em proporções distintas (45,5\% dos casos). 
Figura 8. Fatores estatisticamente relacionados à sensação descrita por mulheres negras vivendo com HIV/AIDS no momento da entrega do resultado do teste. São Paulo, 2000.

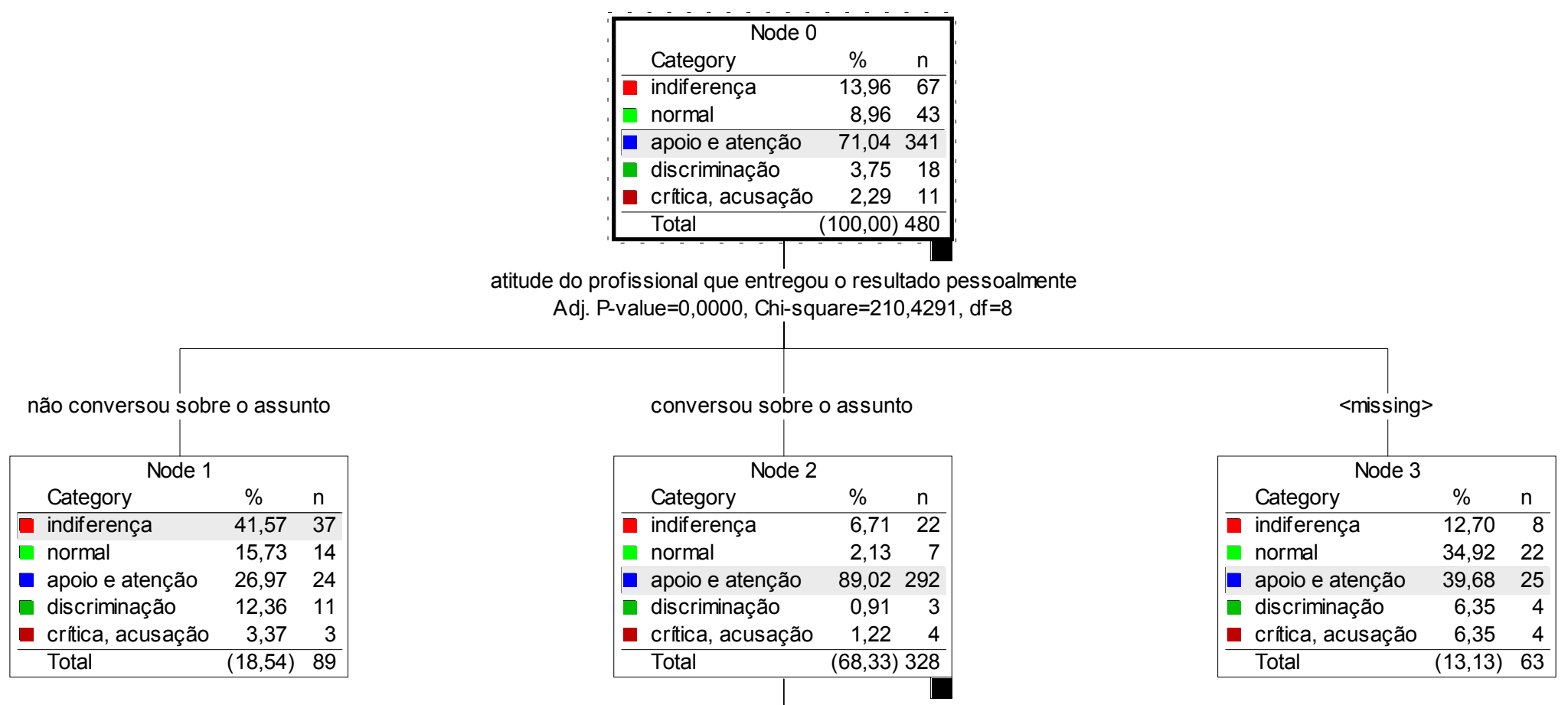

via de exposição

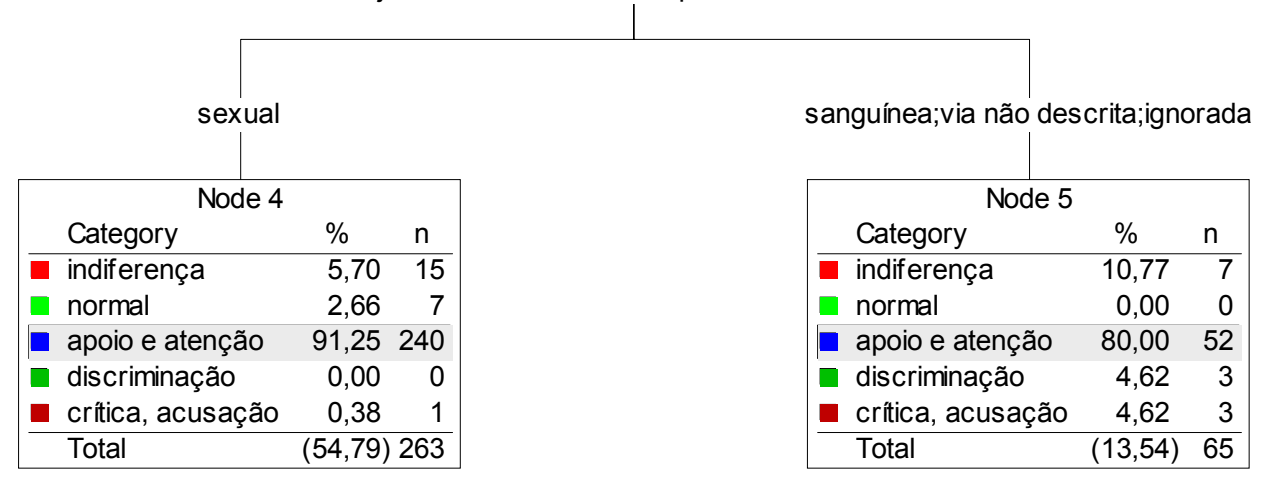


Figura 9. Fatores estatisticamente relacionados à sensação descrita por mulheres não negras vivendo com HIV/AIDS no momento da entrega do resultado do teste. São Paulo, 2000.

SENTIU

\begin{tabular}{|lrr|}
\hline Node 0 & \\
Category & \multicolumn{1}{c|}{$\%$} & \multicolumn{1}{c|}{$\mathrm{n}$} \\
\hline crítica, acusação & 1,08 & 5 \\
normal & 12,34 & 57 \\
apoio e atenção & 63,85 & 295 \\
indiferença & 17,10 & 79 \\
discriminação & 5,63 & 26 \\
\hline Total & $(100,00)$ & 462 \\
\hline
\end{tabular}

atitude do profissional que entregou o resultado pessoalmente Adj. P-value $=0,0000$, Chi-square $=173,1015, \mathrm{df}=8$

não conversou sobre o assunto

\begin{tabular}{|lrr|}
\hline \multicolumn{1}{|c|}{ Node 1} & & \\
Category & \multicolumn{1}{c|}{$\%$} & \multicolumn{1}{c|}{$\mathrm{n}$} \\
\hline crítica, acusação & 2,73 & 3 \\
normal & 22,73 & 25 \\
apoio e atenção & 20,00 & 22 \\
$\square$ indiferença & 43,64 & 48 \\
discriminação & 10,91 & 12 \\
\hline Total & $(23,81)$ & 110 \\
\hline
\end{tabular}

conversou sobre o assunto

\begin{tabular}{|lrr|}
\hline \multicolumn{1}{|c}{ Node 2 } & & \\
Category & \multicolumn{1}{c|}{$\%$} & \multicolumn{1}{c|}{$\mathrm{n}$} \\
\hline crítica, acusação & 0,00 & 0 \\
normal & 4,55 & 13 \\
apoio e atenção & 84,97 & 243 \\
indiferença & 6,99 & 20 \\
discriminação & 3,50 & 10 \\
\hline Total & $(61,90)$ & 286 \\
\hline
\end{tabular}

$<$ missing $>$

\begin{tabular}{|lrr|}
\hline Category & \multicolumn{1}{c|}{ Node 3} & \multicolumn{1}{c|}{ n } \\
\hline - crítica, acusação & 3,03 & 2 \\
normal & 28,79 & 19 \\
apoio e atenção & 45,45 & 30 \\
a indiferença & 16,67 & 11 \\
q discriminação & 6,06 & 4 \\
\hline Total & $(14,29)$ & 66 \\
\hline
\end{tabular}


$\mathrm{Na}$ análise do "tempo que demorou em procurar o serviço de saúde" foram integradas as variáveis:

- faixa etária;

- nível de escolaridade;

- renda individual mensal;

- renda familiar per capita mensal;

- contribuição individual para a renda familiar;

- tempo de infecção diagnosticada;

- local onde realizou o teste;

- percepção de risco;

- faixa etária no momento do diagnóstico;

- idade da iniciação sexual;

- número de parceiros sexuais durante a vida;

- razão da testagem;

- atitude do profissional que entregou o resultado do teste;

- sensação despertada no momento da entrega do resultado;

- número de filhos soropositivos;

- número de pessoas que cuida;

- tempo que demorou em contar ao parceiro da época;

- tempo que demorou em contar à família;

- tempo que demorou em contar aos filhos;

- tempo que demorou em contar aos amigos;

- tempo que demorou em contar no trabalho da época.

O conjunto de dados apresentados para as mulheres negras foi partido primeiramente em 3 ramos, segundo a variável "tempo de infecção diagnosticada": ramo 1. mulheres negras diagnosticadas há 1 ano ou menos e aquelas que não souberam precisar o tempo de diagnóstico; 2. mulheres negras diagnosticadas num período superior a 1 ano, igual ou inferior a 4 anos; 3 . mulheres negras diagnosticadas há mais de 4 anos. Do ramo 1 surgiram dois novos ramos partindo da variável "tempo que demorou em contar (o resultado do exame) à família": ramo 4. formado por mulheres negras que demoraram 1 mês ou menos para divulgar o resultado à família; e o ramo 5 . formado por mulheres negras que demoraram mais 
de 1 mês para fazê-lo. Do ramo 2 derivaram os ramos 6 e 7, de acordo com a variável "tempo que demorou em contar aos filhos". No ramo 6 foram agrupadas as mulheres negras que contaram o resultado do teste aos seus filhos num período igual ou inferior a 3 meses e no ramo 7 as mulheres negras que demoraram mais de 3 meses para divulgá-lo (Figura 10).

Para mais da metade das mulheres negras diagnosticadas há mais de 4 meses (divisão 3), a procura pelo serviço especializado foi muito rápida (menos de 1 mês), demorando 7 meses ou mais para 21,48\%. Para aquelas diagnosticadas há mais de 1 e menos de 4 meses foi uma grande vantagem contar rapidamente aos filhos; nesse caso, todas demoraram, no máximo 3 meses para iniciar o acompanhamento em serviço especializado. O fato de a família saber foi decisivo para aquelas com diagnóstico recente ( 1 mês ou menos) e para aquelas que não souberam precisar a data do diagnóstico, dado que, dentre as mulheres que divulgaram mais rapidamente sua condição sorológica para a família (1 mês ou menos), 98,70\% buscaram um serviço especializado em 3 meses ou menos (dentre aquelas que demoraram um pouco mais em divulgar à família, 8,47\% chegaram ao serviço de 4 a 12 meses após o diagnóstico). 
Figura 10. Fatores estatisticamente relacionados ao tempo que mulheres negras vivendo com HIV/AIDS demoraram em procurar o serviço de saúde especializado. São Paulo, 2000.

tempo que demorou para procurar um serviço especializado (meses)

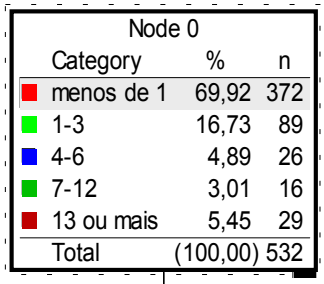

tempo de infecção (anos)

Adj. P-value $=0,0000$, Chi-square $=48,7068, \mathrm{df}=2$

\begin{tabular}{|c|c|c|}
\hline \multicolumn{3}{|c|}{$<=1$ ou menos, $<$ missing $>$} \\
\hline \multicolumn{3}{|c|}{ Node 1} \\
\hline Category & $\%$ & $\mathrm{n}$ \\
\hline menos de 1 & 80,15 & 109 \\
\hline$\square 1-3$ & 15,44 & 21 \\
\hline - 4-6 & 2,94 & 4 \\
\hline - 7-12 & 1,47 & 2 \\
\hline 13 ou mais & 0,00 & 0 \\
\hline Total & $(25,56)$ & 136 \\
\hline
\end{tabular}

tempo que demorou $p /$ contar à tanti Adj. P-value $=0,0229$, Chi-square $=7,1206, \mathrm{df}=1$

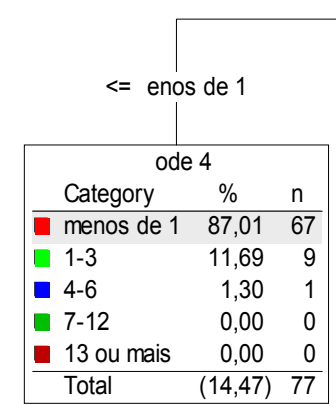

$>$ menos de 1

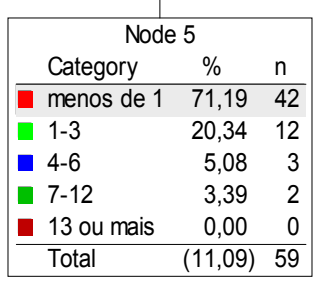

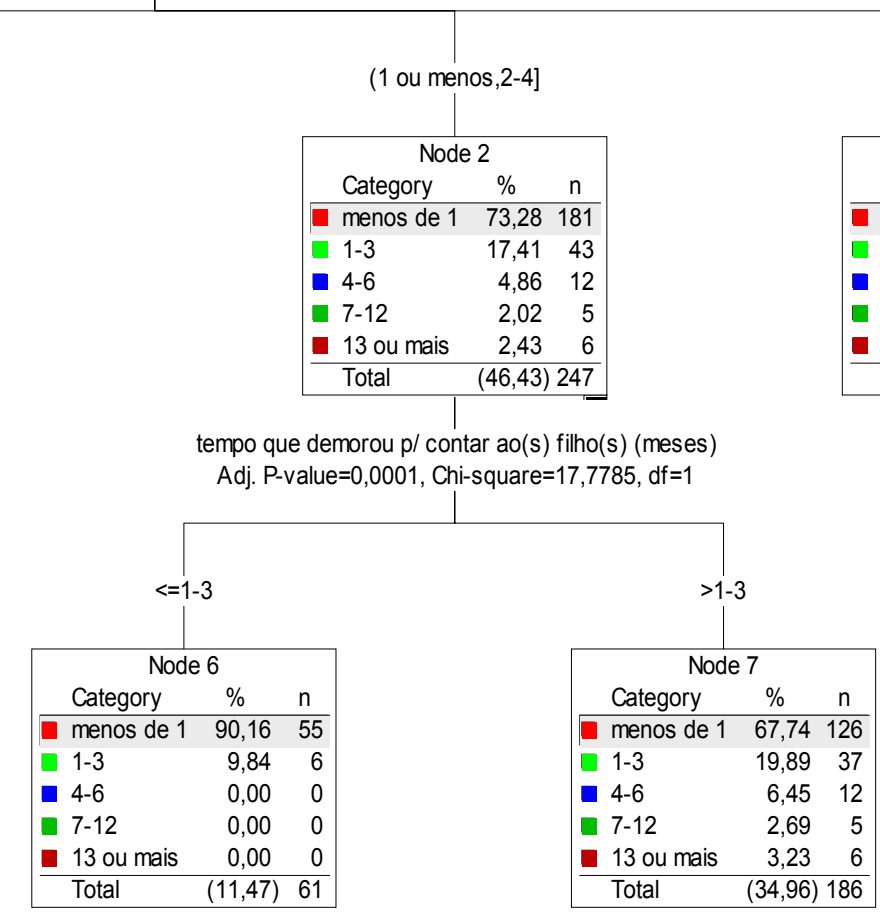


Como descrito na Figura 11, para as não negras o grupo foi dividido, inicialmente, segundo a variável "tempo de infecção diagnosticada" (ramo 1 composto por aquelas que receberam o resultado há 4 meses ou menos; ramo 2 composto pelas demais). Da ramificação 1 surgiram 2 novas: ramificação 3 (mulheres que receberam algum tipo de orientação no momento anterior ao teste e mulheres que não souberam ou quiseram fornecer informação sobre esse momento) e ramificação 4 (mulheres que não sabiam que estavam sendo testadas e mulheres que não receberam aconselhamento pré-teste). Da ramificação 2 derivaram os ramos $5 \mathrm{e}$ 6. O primeiro formado por mulheres não negras que referiram sensação de crítica/acusação, discriminação ou normalidade diante da atitude do profissional que entregou o resultado do teste e aquelas que não souberam qualificar a sensação, e o segundo composto por mulheres não negras que referiram apoio/atenção ou indiferença.

No grupo das mulheres não negras que tiveram a infecção diagnosticada mais recentemente e que contaram com algum tipo de orientação anterior à testagem foi observada maior proporção de mulheres que buscou o serviço especializado em menos de 1 mês; contudo, o grupo que deixou de receber orientação era numericamente maior, logo em termos absolutos lá foi encontrada a maioria das mulheres que iniciou o tratamento rapidamente e, ao mesmo tempo, a maioria daquelas que demorara 7 meses e mais.

Para as mulheres que tiveram diagnóstico num período maior que 4 meses anteriores à realização da pesquisa, aquelas que relataram sensações negativas diante da atitude do profissional que lhe informou sobre a nova condição sorológica, mostraram-se mais relutantes em procurar o serviço especializado $(36,20 \%$ das mulheres demoraram 7 meses ou mais e 37,93\% demoraram menos de 1 mês). Situação distinta foi observada para as demais (61,95\% relataram ter demorado menos de 1 mês e 16,81\% demoraram 7 meses ou mais). 
Figura 11. Fatores estatisticamente relacionados ao tempo que mulheres não negras vivendo com HIV/AIDS demoraram em procurar o serviço de saúde especializado. São Paulo, 2000.

tempo que demorou para procurar um serviço especializado (meses)

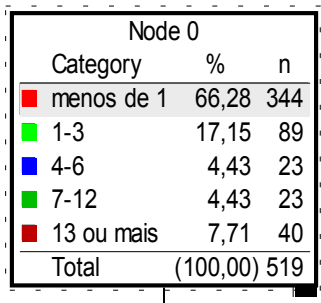

tempo de infecção (anos)

Adj. P-value $=0,0000$, Chi-square $=36,5732, \mathrm{df}=1$

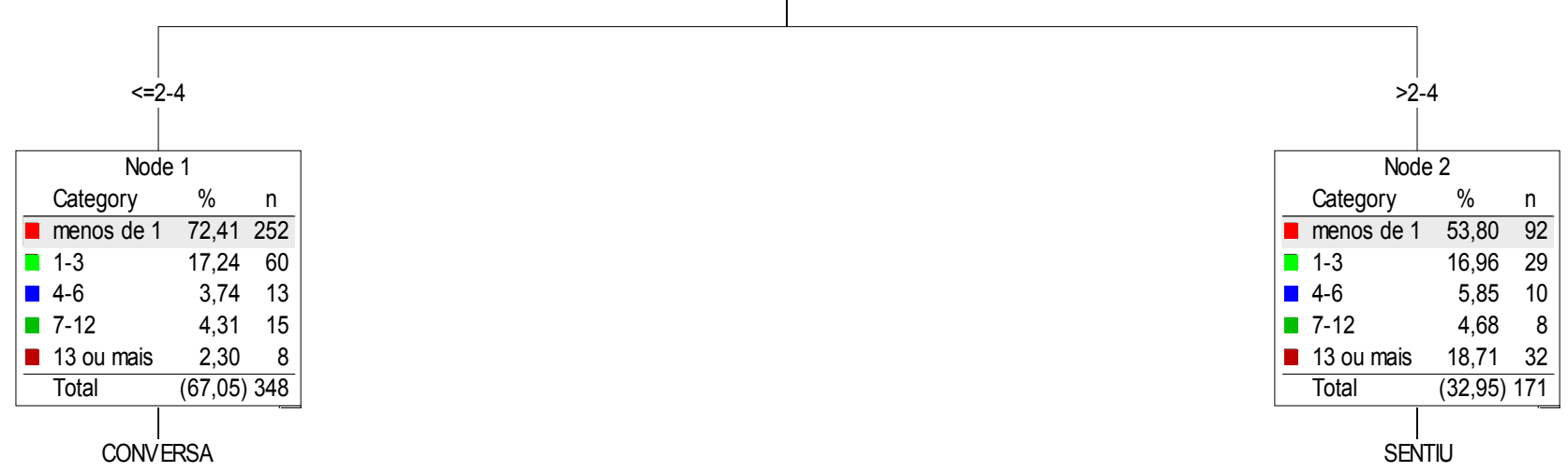

Adj. P-value $=0,0005$, Chi-square $=17,3464, \mathrm{df}=1$

Adj. P-value $=0,0251$, Chi-square $=11,2208, \mathrm{df}=1$

individual;em grupo,<missing $>$

\begin{tabular}{|c|c|c|}
\hline \multicolumn{3}{|c|}{ Node 3} \\
\hline Category & $\%$ & $n$ \\
\hline menos de & 82,19 & 120 \\
\hline $1-3$ & 14,38 & 21 \\
\hline - 4-6 & 1,37 & 2 \\
\hline $7-12$ & 1,37 & 2 \\
\hline D 13 ou mais & 0,68 & 1 \\
\hline Total & $(28,13)$ & 146 \\
\hline
\end{tabular}

não recebeu orientação;não sabia que estava sendo testada

\begin{tabular}{|lrr|}
\hline \multicolumn{3}{|c|}{ Node 4} \\
Category & $\%$ & \multicolumn{1}{c|}{$\mathrm{n}$} \\
\hline menos de 1 & 65,35 & 132 \\
\hline $1-3$ & 19,31 & 39 \\
- $4-6$ & 5,45 & 11 \\
$7-12$ & 6,44 & 13 \\
13 ou mais & 3,47 & 7 \\
\hline Total & $(38,92)$ & 202 \\
\hline
\end{tabular}

crítica, acusação;normal;discriminação,<missing>

\begin{tabular}{|c|c|c|c|}
\hline \multicolumn{4}{|c|}{ Node 5} \\
\hline & Category & $\%$ & $\mathrm{n}$ \\
\hline 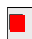 & menos de 1 & 37,93 & 22 \\
\hline$\square$ & $1-3$ & 17,24 & 10 \\
\hline I & $4-6$ & 8,62 & 5 \\
\hline 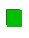 & $7-12$ & 5,17 & 3 \\
\hline ב & 13 ou mais & 31,03 & 18 \\
\hline & Total & $(11,18)$ & 58 \\
\hline
\end{tabular}

apoio e atenção;indiferença

\begin{tabular}{|lrr|}
\hline \multicolumn{3}{|c|}{ Node 6 } \\
Category & $\%$ & \multicolumn{1}{c|}{} \\
\hline menos de 1 & 61,95 & 70 \\
$1-3$ & 16,81 & 19 \\
$4-6$ & 4,42 & 5 \\
$7-12$ & 4,42 & 5 \\
13 ou mais & 12,39 & 14 \\
\hline Total & $(21,77)$ & 113 \\
\hline
\end{tabular}




\subsubsection{Estudo das variáveis-resposta relacionadas à vida sexual após o diagnóstico de soropositividade para o HIV}

A análise do "uso de preservativo após o diagnóstico" envolveu as seguintes variáveis independentes:

- faixa etária;

- nível de escolaridade;

- renda individual mensal;

- renda familiar per capita mensal;

- contribuição individual para a renda familiar;

- tempo de infecção diagnosticada;

- número de filhos soropositivos;

- número de pessoas que cuida;

- tipo de parceria atual;

- condição sorológica do parceiro;

- parceiro sabe que é soropositiva;

- pensa em ter filhos;

- tempo de infecção diagnosticada;

- informação sobre transmissão durante a gravidez;

- informação sobre prevenção de reinfecção;

- informação sobre prevenção em parcerias sorodiscordantes;

- informação sobre terapia anti-retroviral;

- facilidade para entender o que o infectologista diz;

- facilidade para falar sobre suas preocupações e tirar dúvidas com o infectologista;

- facilidade em falar sobre sua vida sexual com o infectologista;

- facilidade para entender o que o ginecologista diz;

- facilidade para falar sobre suas preocupações e tirar dúvidas com o ginecologista;

- facilidade em falar sobre sua vida sexual com o ginecologista;

- contagem de células TCD4;

- significado do exame de CD4;

- significado do exame de carga viral; 
Para as mulheres negras, o uso de preservativo foi influenciado pela condição sorológica do parceiro fixo atual e pelo número de pessoas que a mulher cuidava. $\mathrm{O}$ conjunto foi dividido, inicialmente em 2 segmentos: 1. mulheres cujo parceiro era sabidamente soropositivo, aquelas que desconheciam a condição e aquelas que não forneceram tal informação; 2. mulheres com parceiros sabidamente soronegativos. A partir do segmento 2 foram gerados novos grupos um composto de mulheres que cuidavam de até 3 pessoas (ramo 3 ) e outro composto de mulheres que cuidavam de mais de 3 pessoas (ramo 4) (Figura 12).

Para as mulheres que se relacionavam sexualmente com parceiros soronegativos (ramo 2), o uso consistente de preservativo (todas as vezes) prevaleceu (82,08\% das respostas), ainda assim, 6 mulheres, num universo de 106, relataram nunca usar preservativo $(5,66 \%)$ e 13 relataram utilizar às vezes $(12,26 \%)$. Para as mulheres negras do ramo 1, as possibilidades de uso do preservativo estavam determinadas pela responsabilidade social assumida: entre aquelas que cuidavam de um número menor de pessoas - até 3, o uso inconsistente correspondeu a 39,74\% $(25,45 \%$ às vezes; $14,29 \%$ nunca); em contrapartida, para aquelas que cuidavam de mais pessoas, a lógica das proporções foi invertida: 27,78\% nunca usavam e 9,72\% usavam às vezes.

Entre as mulheres não negras o único fator preditor do uso de preservativo foi a facilidade em obtê-lo no serviço de saúde onde se trata (Figura 13). Para aquelas que relataram ter facilidade na maioria das vezes ou às vezes (ramo 1), o uso consistente correspondeu a 72,93\% dos casos. Nesse grupo apenas 4,89\% das mulheres relataram nunca usar preservativo. Para aquelas que referiram nunca ter facilidade em obter o recurso preventivo no serviço de saúde (ramo 2), ainda prevaleceu o uso consistente (63,83\%); entretanto houve nítido aumento da porcentagem de mulheres que referiram nunca utilizá-lo em suas relações sexuais $(17,73 \%)$. 
Figura 12. Fatores estatisticamente relacionados ao uso de preservativo após o diagnóstico de infecção pelo HIV para mulheres negras. São Paulo, 2000.

uso de preservativo

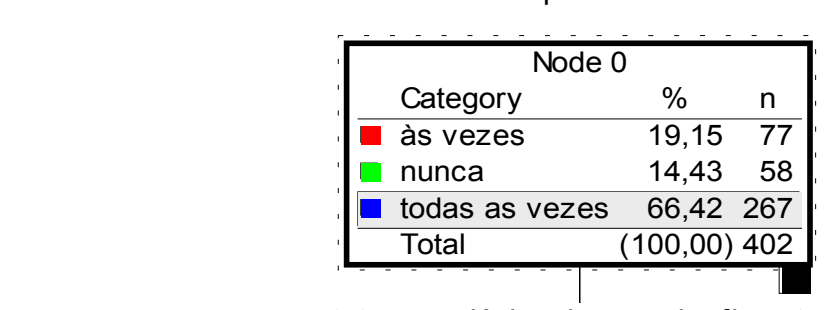

status sorológico do parceiro fixo atual

Adj. P-value $=0,0018$, Chi-square $=16,5516, d f=2$

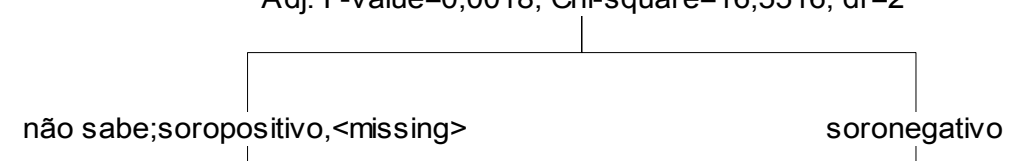

\begin{tabular}{|lrr|}
\hline \multicolumn{3}{|c|}{ Node 1} \\
\multicolumn{1}{|c|}{ Category } & $\%$ & \multicolumn{1}{c|}{$\mathrm{n}$} \\
\hline às vezes & 21,62 & 64 \\
nunca & 17,57 & 52 \\
\hline todas as vezes & 60,81 & 180 \\
\hline \multicolumn{1}{|l|}{ Total } & $(73,63)$ & 296 \\
\hline
\end{tabular}

\begin{tabular}{|lrr|}
\hline \multicolumn{1}{|c|}{ Node 2} & \\
\multicolumn{1}{|c|}{ Category } & \multicolumn{1}{c|}{$\%$} & \multicolumn{1}{c|}{$\mathrm{n}$} \\
\hline às vezes & 12,26 & 13 \\
nunca & 5,66 & 6 \\
todas as vezes & 82,08 & 87 \\
\hline Total & $(26,37)$ & 106 \\
\hline
\end{tabular}

número de pessoas que cuida

Adj. P-value $=0,0103$, Chi-square $=11,9213, \mathrm{df}=2$

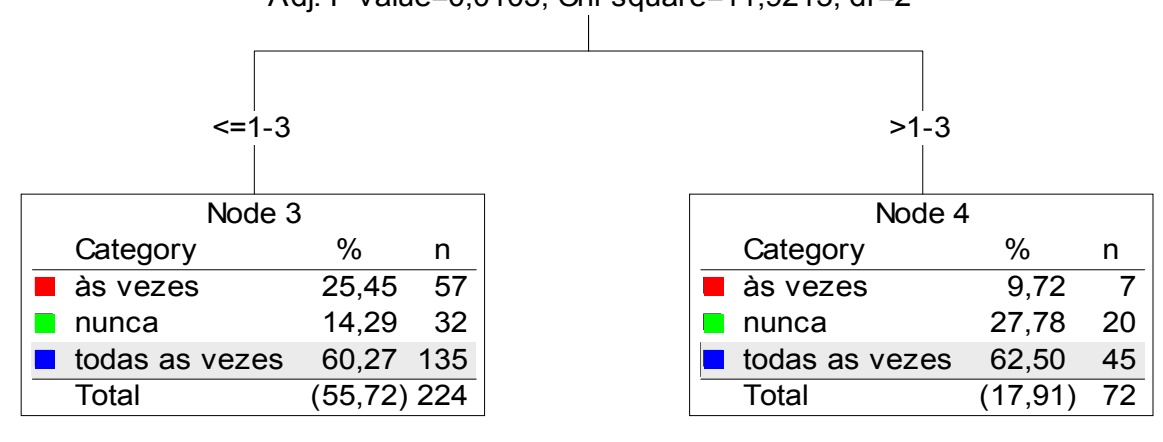


Figura 13. Fatores estatisticamente relacionados ao uso de preservativo após o diagnóstico de infecção pelo HIV para mulheres não negras. São Paulo, 2000.

uso de preservativo

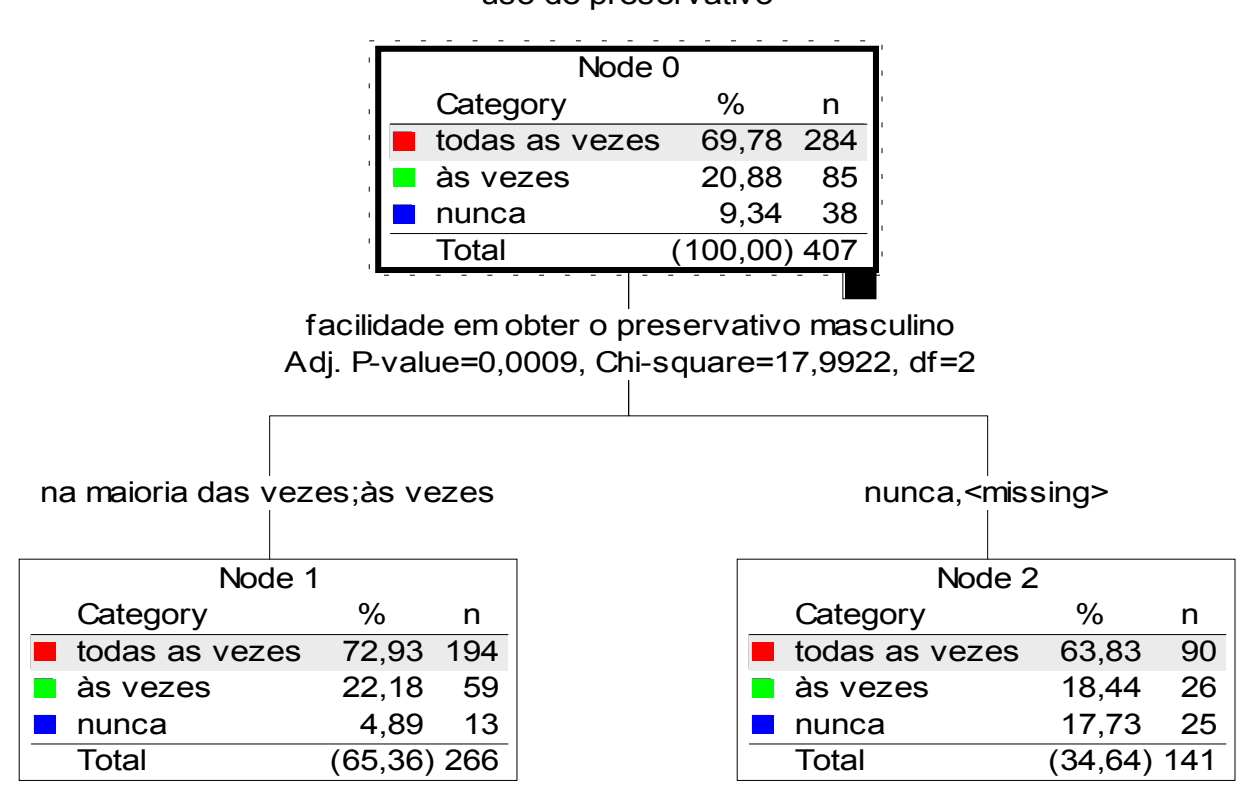




\subsubsection{Estudo das variáveis-resposta relacionadas ao vínculo com o serviço de saúde especializado e à qualidade do cuidado}

O modelo de análise da variável dependente "facilidade em obter outros remédios que não o coquetel" considerou como possíveis variáveis explicativas os fatores:

- faixa etária;

- nível de escolaridade;

- renda individual mensal;

- renda familiar per capita mensal;

- contribuição individual para a renda familiar;

- local de atendimento;

- número de filhos soropositivos;

- número de pessoas que cuida;

- tipo de parceria atual;

- tempo de infecção diagnosticada;

- meios de acesso ao serviço especializado;

- tempo gasto para chegar ao serviço de saúde onde se trata;

- tempo de segmento no serviço de saúde;

- freqüência de falta às consultas;

- contagem de células TCD4;

- significado do exame CD4;

- significado do exame de carga viral.

De acordo com os dados apresentados na Figura 14, no conjunto das mulheres negras o "local de atendimento" mostrou-se estatisticamente determinante da "facilidade de obtenção de outros remédios", como aquelas atendidas na Casa da Aids (CAIDS/FMUSP) em que pouco menos da metade $(59,26 \%)$ relatou ter facilidade na maioria das vezes enquanto $17,90 \%$ relataram nunca ter facilidade (ramificação 1). Na ramificação 2 que congregava mulheres atendidas no Centro de Referência em AIDS (CRAIDS) da Secretaria Municipal de Saúde de Santos e no Centro de Referência e Treinamento do Programa Estadual de DST/AIDS (CRTDST/AIDS-SP) da Secretaria de Estado da Saúde (SES-SP), apenas 3,72\% relataram nunca ter facilidade e $73,37 \%$ relataram ter facilidade na maioria das vezes. 
Figura 14. Fatores estatisticamente relacionados à facilidade descrita por mulheres negras vivendo com HIV/AIDS em obter outros remédios além do coquetel.

São Paulo, 2000.

facilidade em obter outros remédios

\begin{tabular}{|c|c|c|c|}
\hline \multicolumn{4}{|c|}{ 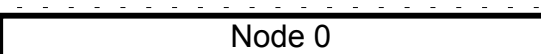 } \\
\hline & Category & $\%$ & $\mathrm{n}$ \\
\hline$\square$ & na maioria das vezes & 68,66 & 333 \\
\hline [ & nunca & 8,45 & 41 \\
\hline & às vezes & 22,89 & 111 \\
\hline & Total & $(100,00)$ & 485 \\
\hline
\end{tabular}

local de atendimento

Adj. $P$-value $=0,0000$, Chi-square $=28,8147, d f=2$

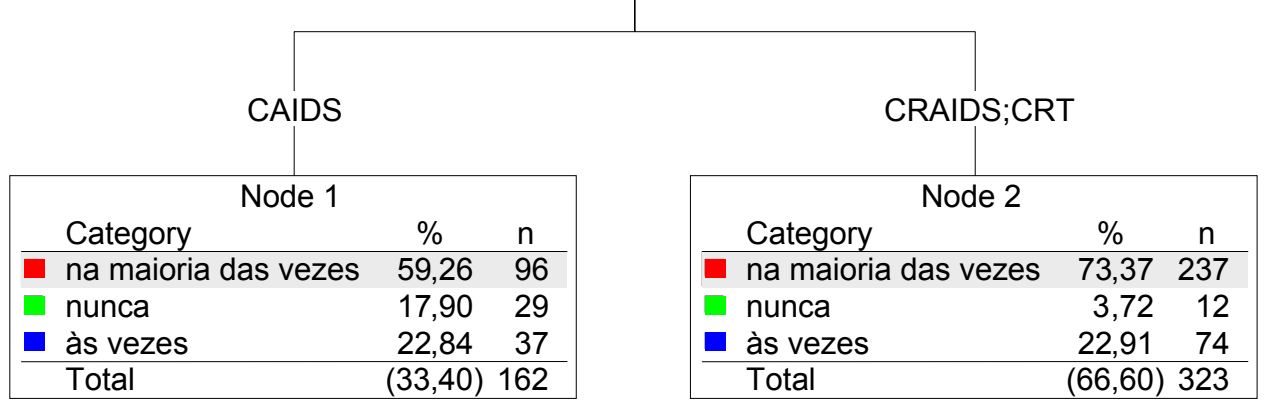


Para as mulheres não negras, além do "local de atendimento", a "facilidade de obtenção de outros remédios" esteve estatisticamente influenciada pelo "tipo de vínculo com parceiro sexual (Figura 15). Na primeira divisão do conjunto de dados foram gerados os segmentos 1 e 2 . O primeiro agrupou mulheres atendidas no CRTDST/AIDS-SP e CRAIDS e o segundo mulheres atendidas na Casa da Aids (CAIDS/FMUSP). A ramificação 2 foi subdividida segundo o tipo de vínculo estabelecido com parceiro atual: foram separadas as mulheres com parceiro fixo (ramo 3) das mulheres sem parceiro ou com parceiros eventuais (ramo 4).

As mulheres não negras atendidas no CRT-DST/AIDS-SP e CRAIDS referiram alguma dificuldade em $26,80 \%$ dos casos (proporção maior que aquela apresentada para as atendidas na CAIDS/FMUSP - 17,54\%); contudo, no primeiro grupo, apenas $4,58 \%$ referiram nunca ter facilidade enquanto, entre as demais, essa referência correspondeu a $11,70 \%$ dos casos.

Na CAIDS/FMUSP, a obtenção dos remédios foi facilitada para aquelas que referiam ter parceiro fixo uma vez que, nesse grupo, 5,66\% relataram nunca ter facilidade enquanto, para aquelas que não tinham parceiro ou que estabeleciam vínculos eventuais, $21,54 \%$ relataram nunca ter facilidade para obter os remédios. 
Figura 15. Fatores estatisticamente relacionados à facilidade descrita por mulheres não negras vivendo com HIV/AIDS em obter outros remédios além do coquetel. São Paulo, 2000.

facilidade em o

\begin{tabular}{||lrr|}
\hline \multicolumn{3}{|c|}{ Node 0} \\
Category & $\%$ & $\mathrm{n}$ \\
$\square$ na maioria das vezes & 69,39 & 331 \\
\hline às vezes & 23,48 & 112 \\
$\square$ nunca & 7,13 & 34 \\
\hline Total & $(100,00)$ & 477 \\
\hline
\end{tabular}

local de atendimento

Adj. $P$-value $=0,0079$, Chi-square $=11,8759, \mathrm{df}=2$

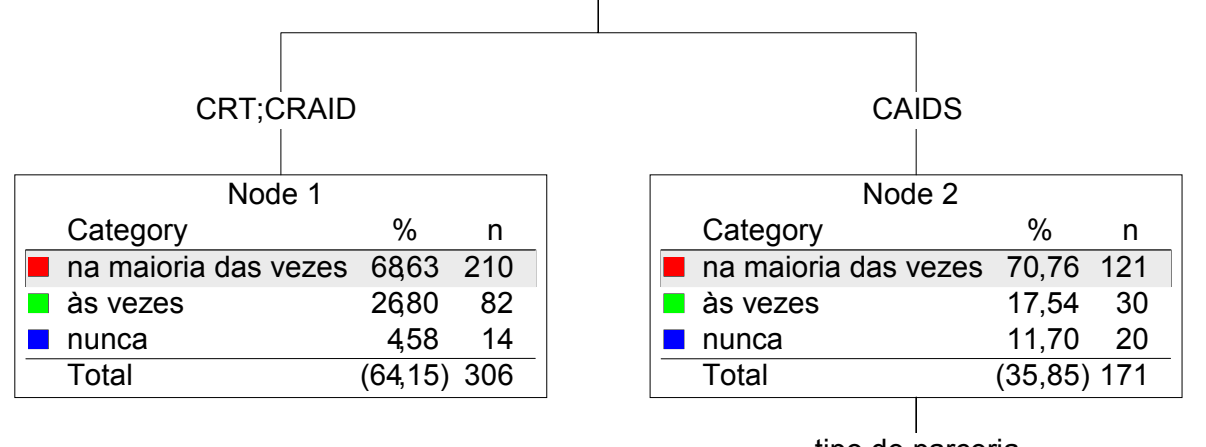

tipo de parceria
Adj. $P$-value $=0,0065$, Chi-square $=10,0621, \mathrm{df}=2$

\begin{tabular}{|c|c|c|c|c|c|c|}
\hline \multicolumn{3}{|c|}{ parceiro fixo } & \multicolumn{4}{|c|}{$<$ missing $>$} \\
\hline \multicolumn{3}{|c|}{ Node 3} & \multicolumn{4}{|c|}{ Node 4} \\
\hline & Category & $\%$ & & Category & $\%$ & $\mathrm{n}$ \\
\hline$\square$ & na maioria das vezes & $74,53 \quad 79$ & $\square$ & na maioria das vezes & 64,62 & 42 \\
\hline & às vezes & $19,81 \quad 21$ & & às vezes & 13,85 & 9 \\
\hline & nunca & 5,66 & & nunca & 21,54 & 14 \\
\hline & Total & $(22,22) 106$ & & Total & $(13,63)$ & 65 \\
\hline
\end{tabular}


O modelo de análise para a "facilidade em entender o que o infectologista diz" levou em consideração as variáveis independentes:

- faixa etária;

- nível de escolaridade;

- renda individual mensal;

- renda familiar per capita mensal;

- contribuição individual para a renda familiar;

- local de atendimento;

- tempo de infecção diagnosticada;

- tempo de segmento no serviço de saúde;

- facilidade em falar sobre suas preocupações e tirar dúvidas com o infectologista;

- facilidade em falar sobre sua vida sexual com o infectologista;

- freqüência de falta às consultas.

Para as mulheres negras foram preditoras a "facilidade em tirar dúvidas com o infectologista" e o "nível de escolaridade" (Figura 16). A possibilidade de entender o que o profissional dizia esteve diretamente influenciada pela possibilidade de com ele solucionar dúvidas dado que, dentre aquelas que relataram ter facilidade em tirar dúvidas (na maioria das vezes), 89,73\% afirmaram entendê-lo, contra $57,78 \%$ das demais (comparação entre os ramos 1 e 2). No entanto, entre aquelas que na maioria das vezes tiravam suas dúvidas, a intelecção melhorava com o aumento do nível de escolaridade: $92,77 \%$ para as mulheres da ramificação 4 - a partir da $5^{\text {a }}$ série; $81,03 \%$ para as mulheres com até a $4^{\text {a }}$ série completa (ramificação 3 ). Foi interessante notar que $3,45 \%$ e $15,52 \%$ das mulheres do ramo 3 relataram nunca entender ou entender às vezes o que dizia o infectologista, embora tivessem relatado facilidade para tirar dúvidas com o mesmo. 
Figura 16. Fatores estatisticamente relacionados à facilidade descrita por mulheres negras vivendo com HIV/AIDS para entender o que o infectologista diz. São Paulo, 2000.

infecto - facilidade em entender

\begin{tabular}{|lrr|}
\hline Category & Node 0 & \multicolumn{1}{c|}{$\mathrm{n}$} \\
\hline nunca & 1,86 & 10 \\
na maioria das vezes & 84,39 & 454 \\
\hline às vezes & 13,75 & 74 \\
\hline Total & $(100,00)$ & 538 \\
\hline
\end{tabular}

infecto - facilidade em tirar dúvidas

Adj. $P$-value $=0,0000$, Chi-square $=58,2650, d f=2$

nunca;às vezes

\begin{tabular}{|lrr|}
\hline Category & Node 1 & \\
& $\%$ & \multicolumn{1}{c|}{$\mathrm{n}$} \\
\hline nunca & 5,56 & 5 \\
\hline na maioria das vezes & 57,78 & 52 \\
às vezes & 36,67 & 33 \\
\hline Total & $(16,73)$ & 90 \\
\hline
\end{tabular}

na maioria das vezes

\begin{tabular}{|c|c|c|c|}
\hline \multicolumn{4}{|c|}{ Node 2} \\
\hline & Category & $\%$ & $\mathrm{n}$ \\
\hline $\bar{\square}$ & nunca & 1,12 & 5 \\
\hline$\square$ & na maioria das vezes & 89,73 & 402 \\
\hline [ & às vezes & 9,15 & 41 \\
\hline & Total & $(83,27)$ & 448 \\
\hline
\end{tabular}

escolaridade ( 3 níveis)

Adj. P-value $=0,0007$, Chi-square $=15,8784, \mathrm{df}=2$
$<=$ até fundamental 1

\begin{tabular}{|lcr|}
\hline \multicolumn{3}{|c|}{ Node 3} \\
Category & $\%$ & \multicolumn{1}{c|}{} \\
\hline nunca & 3,45 & 4 \\
na maioria das vezes & 81,03 & 94 \\
às vezes & 15,52 & 18 \\
\hline Total & $(21,56)$ & 116 \\
\hline
\end{tabular}

>até fundamental 1

\begin{tabular}{|lrr|}
\hline \multicolumn{3}{|c|}{ Node 4} \\
Category & \multicolumn{1}{c|}{$\%$} & \multicolumn{1}{c|}{$\mathrm{n}$} \\
\hline nunca & 0,30 & 1 \\
na maioria das vezes & 92,77 & 308 \\
às vezes & 6,93 & 23 \\
\hline Total & $(61,71)$ & 332 \\
\hline
\end{tabular}


Com um padrão de divisão semelhante àquele apresentado para as negras, as mulheres não negras tiveram a "facilidade em entender o que o infectologista diz" estatisticamente influenciada pela facilidade em tirar dúvidas com o mesmo profissional e um fator estrutural que, nesse caso, foi a renda individual mensal (Figura 17).

Da primeira partição dos dados derivou a distinção entre mulheres que na maioria das vezes tinha suas dúvidas solucionadas pelo infectologista e mulheres que às vezes tinham facilidade ou que nunca tinham facilidade. Para estas, as dificuldades foram nitidamente maiores $(30,88 \%$ às vezes e 5,88\% nunca - ramo 2 contra $4,61 \%$ às vezes e $0,00 \%$ nunca - ramo 1 ). Para aquelas com facilidade em tirar dúvidas pesou a renda individual mensal: as que recebiam menos (até 3 salários mínimos) apresentavam maiores dificuldades em entender que as demais. 
Figura 17. Fatores estatisticamente relacionados à facilidade descrita por mulheres não negras vivendo com HIV/AIDS para entender o que o infectologista diz. São Paulo, 2000.

infecto - facilidade em entender

\begin{tabular}{|lrr|}
\hline Category & Node 0 & \\
\hline na maioria das vezes & \multicolumn{1}{c|}{91,22} & \multicolumn{1}{c|}{ n } \\
\hline às vezes & 8,02 & 42 \\
nunca & 0,76 & 4 \\
\hline Total & $(100,00)$ & 524 \\
\hline
\end{tabular}

infecto - facilidade em tirar dúvidas

Adj. $P$-value $=0,0000$, Chi-square $=84,5102, \mathrm{df}=2$

na maioria das vezes

\begin{tabular}{|lrr|}
\hline Category & \multicolumn{1}{c|}{ Node 1} & \multicolumn{1}{c|}{$\mathrm{n}$} \\
\hline na maioria das vezes & 95,39 & 435 \\
às vezes & 4,61 & 21 \\
nunca & 0,00 & 0 \\
\hline Total & $(87,02)$ & 456 \\
\hline
\end{tabular}

nunca;às vezes

\begin{tabular}{|lrr|}
\hline \multicolumn{1}{|c}{ Node 2} & & \\
Category & \multicolumn{1}{c}{$\%$} & \multicolumn{1}{c}{$\mathrm{n}$} \\
\hline na maioria das vezes & 63,24 & 43 \\
\hline às vezes & 30,88 & 21 \\
nunca & 5,88 & 4 \\
\hline Total & $(12,98)$ & 68 \\
\hline
\end{tabular}

renda individual mensal agrupada (salários mínimos)

Adj. P-value $=0,0414$, Chi-square $=8,3928, \mathrm{df}=1$

$<=$ mais de 1 a 3

\begin{tabular}{|lrr|}
\hline Category & \multicolumn{1}{c|}{ Node 3} & \multicolumn{1}{c|}{$\mathrm{n}$} \\
\hline na maioria das vezes & 91,33 & 137 \\
às vezes & 8,67 & 13 \\
nunca & 0,00 & 0 \\
\hline Total & $(28,63)$ & 150 \\
\hline
\end{tabular}

$>$ mais de 1 a $3,<$ missing $>$

\begin{tabular}{|lrr|}
\hline Category & \multicolumn{1}{c|}{ Node 4} & \multicolumn{1}{c|}{$\mathrm{n}$} \\
\hline na maioria das vezes & 97,39 & 298 \\
às vezes & 2,61 & 8 \\
nunca & 0,00 & 0 \\
\hline Total & $(58,40)$ & 306 \\
\hline
\end{tabular}


Para o estudo do objeto "facilidade em entender o que o ginecologista diz" foram elencadas as variáveis explicativas:

- faixa etária;

- nível de escolaridade;

- renda individual mensal;

- renda familiar per capita mensal;

- contribuição individual para a renda familiar;

- local de atendimento;

- tempo de infecção diagnosticada;

- tempo de segmento no serviço de saúde;

- freqüência de falta às consultas;

- facilidade em falar sobre suas preocupações e tirar dúvidas com o ginecologista;

- facilidade em falar sobre sua vida sexual com o ginecologista.

No grupo das mulheres negras apresentou-se estatisticamente relacionada à facilidade em tirar dúvidas com o ginecologista e o local de atendimento (Figura 18).

$\mathrm{Na}$ ramificação 1 (mulheres que na maioria das vezes tinham facilidade em tirar suas dúvidas com o ginecologista) foi observada a maior proporção de mulheres que entendiam o que o profissional dizia (90,41\%). Nesse grupo, apenas 1 mulher relatou nunca entender o especialista. Ao contrário, dentre aquelas que apresentavam alguma dificuldade em solucionar suas dúvidas, apenas 55,56\% entendiam os dizeres do ginecologista (ramo 2). Não obstante as mulheres atendidas no CRT e CAIDS ramo 4 - relatassem às vezes ter facilidade em entender numa freqüência razoável $(37,04 \%)$, a dificuldade de comunicação foi ainda maior entre as mulheres atendidas no CRAIDS (ramo 3). 
Figura 18. Fatores estatisticamente relacionados à facilidade descrita por mulheres negras vivendo com HIV/AIDS para entender o que o ginecologista diz. São Paulo, 2000.

gineco - facilidade em entender

\begin{tabular}{|lrr|}
\hline Category & \multicolumn{1}{c}{ Node 0} & $\mathrm{n}$ \\
\hline na maioria das vezes & 78,27 & 263 \\
às vezes & 18,45 & 62 \\
nunca & 3,27 & 11 \\
\hline Total & $(100,00)$ & 336 \\
\hline
\end{tabular}

gineco - facilidade em tirar dúvidas

Adj. P-value $=0,0000$, Chi-square $=56,6885, d f=2$

na maioria das vezes, $<$ missing $>$

\begin{tabular}{|lrr|}
\hline \multicolumn{3}{|c|}{ Node 1} \\
Category & \multicolumn{1}{c|}{$\%$} & \multicolumn{1}{c|}{$\mathrm{n}$} \\
\hline na maioria das vezes & 90,41 & 198 \\
às vezes & 9,13 & 20 \\
nunca & 0,46 & 1 \\
\hline Total & $(65,18)$ & 219 \\
\hline
\end{tabular}

às vezes;nunca

\begin{tabular}{|lrr|}
\hline \multicolumn{1}{|c|}{ Node 2} \\
Category & \multicolumn{1}{c|}{$\%$} & $\mathrm{n}$ \\
\hline na maioria das vezes & 55,56 & 65 \\
\hline às vezes & 35,90 & 42 \\
nunca & 8,55 & 10 \\
\hline \multicolumn{1}{|c}{ Total } & $(34,82)$ & 117 \\
\hline
\end{tabular}

local de atendimento

Adj. P-value $=0,0247$, Chi-square $=9,5982, \mathrm{df}=2$

\begin{tabular}{|c|c|c|c|c|c|c|c|}
\hline \multicolumn{4}{|c|}{ CRAIDS } & \multicolumn{4}{|c|}{ CAIDS;CRT } \\
\hline \multicolumn{4}{|c|}{ Node 3} & \multicolumn{4}{|c|}{ Node 4} \\
\hline & Category & $\%$ & $\mathrm{n}$ & & Category & $\%$ & $\mathrm{n}$ \\
\hline 口 & na maioria das vezes & 49,21 & 31 & $\bar{\square}$ & na maioria das vezes & 62,96 & 34 \\
\hline & às vezes & 34,92 & 22 & & às vezes & 37,04 & 20 \\
\hline 口 & nunca & 15,87 & 10 & & nunca & 0,00 & 0 \\
\hline & Total & $(18,75)$ & 63 & & Total & $(16,07)$ & 54 \\
\hline
\end{tabular}


Para as mulheres negras, a variável "facilidade em tirar dúvidas com o ginecologista" também se mostrou estatisticamente importante (Figura 19), e mais notadamente o entenderam aquelas que também tiveram facilidade em tirar dúvidas $(94,81 \%)$, em contraposição às demais que relataram facilidade em 58,62\% e dificuldade em 10,34\% dos casos (ramo 2).

Para estudar a comunicação com o infectologista no tocante à "facilidade em conversar sobre a vida sexual" foram elencadas como variáveis independentes:

- faixa etária;

- nível de escolaridade;

- renda individual mensal;

- renda familiar per capita mensal;

- contribuição individual para a renda familiar;

- local de atendimento;

- número de filhos soropositivos;

- número de pessoas que cuida;

- número de parceiros sexuais durante a vida;

- tipo de parceria atual;

- condição sorológica do parceiro;

- uso de preservativo;

- pensa em ter filhos;

- tempo de infecção diagnosticada;

- informação sobre transmissão durante a gravidez;

- informação sobre prevenção de reinfecção;

- informação sobre terapia anti-retroviral;

- facilidade em entender o que o infectologista diz;

- facilidade em falar sobre suas preocupações e tirar dúvidas com o infectologista;

- facilidade em entender o que o ginecologista diz;

- facilidade em falar sobre suas preocupações e tirar dúvidas com o ginecologista;

- facilidade em falar sobre sua vida sexual com o ginecologista;

- contagem de células TCD4;

- significado do exame de CD4;

- significado do exame de carga viral. 
Figura 19. Fatores estatisticamente relacionados à facilidade descrita por mulheres não negras vivendo com HIV/AIDS para entender o que o ginecologista diz.

São Paulo, 2000.

gineco - facilidade em entender

\begin{tabular}{|lrr|}
\hline \multicolumn{3}{c}{ Node 0} \\
Category & $\%$ & \multicolumn{1}{c|}{$\mathrm{n}$} \\
\hline na maioria das vezes & 84,28 & 252 \\
às vezes & 12,71 & 38 \\
nunca & 3,01 & 9 \\
\hline Total & $(100,00)$ & 299 \\
\hline
\end{tabular}

gineco - facilidade em tirar dúvidas

Adj. P-value $=0,0000$, Chi-square $=63,9401, \mathrm{df}=2$

na maioria das vezes, $<$ missing $>$

\begin{tabular}{lrr} 
& Node 1 & \\
Category & \multicolumn{1}{c}{$\%$} & \multicolumn{1}{c}{$\mathrm{n}$} \\
\hline na maioria das vezes & 94,81 & 201 \\
às vezes & 5,19 & 11 \\
nunca & 0,00 & 0 \\
\hline Total & $(70,90)$ & 212 \\
\hline
\end{tabular}

às vezes;nunca

\begin{tabular}{|lrr|}
\hline \multicolumn{3}{|c}{ Node 2 } \\
Category & $\%$ & \multicolumn{1}{c|}{$\mathrm{n}$} \\
\hline na maioria das vezes & 58,62 & 51 \\
às vezes & 31,03 & 27 \\
nunca & 10,34 & 9 \\
\hline Total & $(29,10)$ & 87 \\
\hline
\end{tabular}


Foi interessante notar que, conforme descrito na Figura 20, para as mulheres negras, a facilidade em falar sobre a vida sexual com o infectologista esteve diretamente relacionada à facilidade de falar sobre o mesmo assunto com o ginecologista, uma vez que os subgrupos coincidiram com as categorias apresentadas por essa variável: entre aquelas que relataram nunca ter facilidade em falar com o ginecologista sobre sua vida sexual (subgrupo 1) prevaleceram as que também não falavam sobre o assunto com o infectologista (73,68\% dos casos); e entre aquelas que na maioria das vezes falavam sobre o assunto com o ginecologista, diminuiu a proporção das que nunca tinham facilidade em falar com o infectologista $(11,03 \%)$ e predominando a categoria "na maioria das vezes" (84,83\%). Ao relatar alguma dificuldade com um dos profissionais, subentendia-se o mesmo com o outro $(45,59 \%$ às vezes; $22,06 \%$ nunca), como descrito na ramificação 3. A ramificação 4 agrupou as mulheres negras que não haviam tentado falar com o ginecologista sobre o assunto ou que sequer haviam passado em consulta com o mesmo. Nesse grupo, a distribuição da facilidade foi de $50 \%$ dos casos, que relatou "na maioria das vezes" e $37,11 \%$ relataram "nunca" (segunda maior proporção dentre os 4 grupos gerados pelo modelo), as demais relataram ter facilidade em algumas vezes. 
Figura 20. Fatores estatisticamente relacionados à facilidade descrita por mulheres negras vivendo com HIV/AIDS para falar sobre sua vida sexual com o infectologista. São Paulo, 2000.

infecto - facilidade em falar da vida sexual

\begin{tabular}{|lrr|}
\hline Category & Node 0 & \\
\hline nunca & 35,89 & 187 \\
\hline na maioria das vezes & 50,86 & 265 \\
às vezes & 13,24 & 69 \\
\hline Total & $(100,00)$ & 521 \\
\hline
\end{tabular}

gineco - facilidade em falar da vida sexual

Adj. P-value $=0,0000$, Chi-square $=199,7886, \mathrm{df}=6$

$\mathrm{nu}$ a

\begin{tabular}{|lrr|}
\hline \multicolumn{3}{|c|}{ No e 1} \\
Category & \multicolumn{1}{c|}{$\%$} & \multicolumn{1}{c|}{$\mathrm{n}$} \\
\hline nunca & 73,68 & \multicolumn{1}{c}{84} \\
na maioria das vezes & 20,18 & 23 \\
às vezes & 6,14 & 7 \\
\hline Total & $(21,88)$ & 114 \\
\hline
\end{tabular}

na maioria das vezes

\begin{tabular}{|lrr|}
\hline \multicolumn{3}{|c|}{ Node 2} \\
Category & \multicolumn{1}{c|}{$\%$} & \multicolumn{1}{c|}{$\mathrm{n}$} \\
\hline nunca & 11,03 & 16 \\
na maioria das vezes & 84,83 & 123 \\
às vezes & 4,14 & 6 \\
\hline Total & $(27,83)$ & 145 \\
\hline
\end{tabular}

às vezes

\begin{tabular}{|lcc|}
\multicolumn{1}{l|}{} & \multicolumn{2}{l|}{ Node 3} \\
Category & $\%$ & $\mathrm{n}$ \\
\hline nunca & 22,06 & 15 \\
na maioria das vezes & 32,35 & 22 \\
\hline às vezes & 45,59 & 31 \\
\hline Total & $(13,05)$ & 68 \\
\hline
\end{tabular}

$<$ missing $>$

\begin{tabular}{lcc} 
& Node 4 & \\
Category & $\%$ & $\mathrm{n}$ \\
\hline nunca & 37,11 & 72 \\
na maioria das vezes & 50,00 & 97 \\
às vezes & 12,89 & 25 \\
\hline Total & $(37,24)$ & 194 \\
\hline
\end{tabular}


Algo semelhante foi observado para as mulheres não negras (Figura 21). Contudo, nesse grupo foram geradas mais 3 partições segundo as variáveis "local de atendimento" e "uso de preservativo masculino".

Para as mulheres não negras que na maioria das vezes falavam sobre sua vida sexual com o ginecologista o faziam também com o infectologista $(84,71 \%$ versus 7,65\% nunca); aquelas que apresentavam alguma dificuldade com o ginecologista, em geral também a tinham com o infectologista (43,40\% às vezes versus $35,85 \%$ na maioria das vezes); e, como era esperado, grande parte daquelas que nunca tinham facilidade em falar com o ginecologista sobre o assunto $(62,69 \%)$ relatavam o mesmo na relação com o infectologista. Nesse grupo apenas $29,85 \%$ das mulheres afirmavam ter facilidade na maioria das vezes.

No segmento 4 - mulheres que não haviam sido atendidas pelo ginecologista ou que não haviam tentado falar sobre sua vida sexual com ele, a comunicação foi facilitada ou dificultada em decorrência de outros dois elementos: o local de atendimento e, no caso daquelas que eram atendidas no CRT e CAIDS, a facilidade variou de acordo com o uso de preservativo após o diagnóstico. Neste grupo, aquelas que aderiram ao uso do preservativo consistentemente (todas as vezes) ou que relataram nunca usar, apresentaram mais facilidade em falar com o especialista sobre sua vida sexual que as mulheres que usavam preservativo em algumas relações sexuais ou que estavam sexualmente inativas naquele momento. Ao comparar as ramificações 7 e 8 foi possível observar que 71,58\% e 13,68\% das mulheres do ramo 7 relatavam ter facilidade na maioria das vezes e nunca, respectivamente versus $55,38 \%$ e $36,92 \%$ das mulheres do ramo 8 . 
Figura 21. Fatores estatisticamente relacionados à facilidade descrita por mulheres não negras vivendo com HIV/AIDS para falar sobre sua vida sexual com o infectologista. São Paulo, 2000.

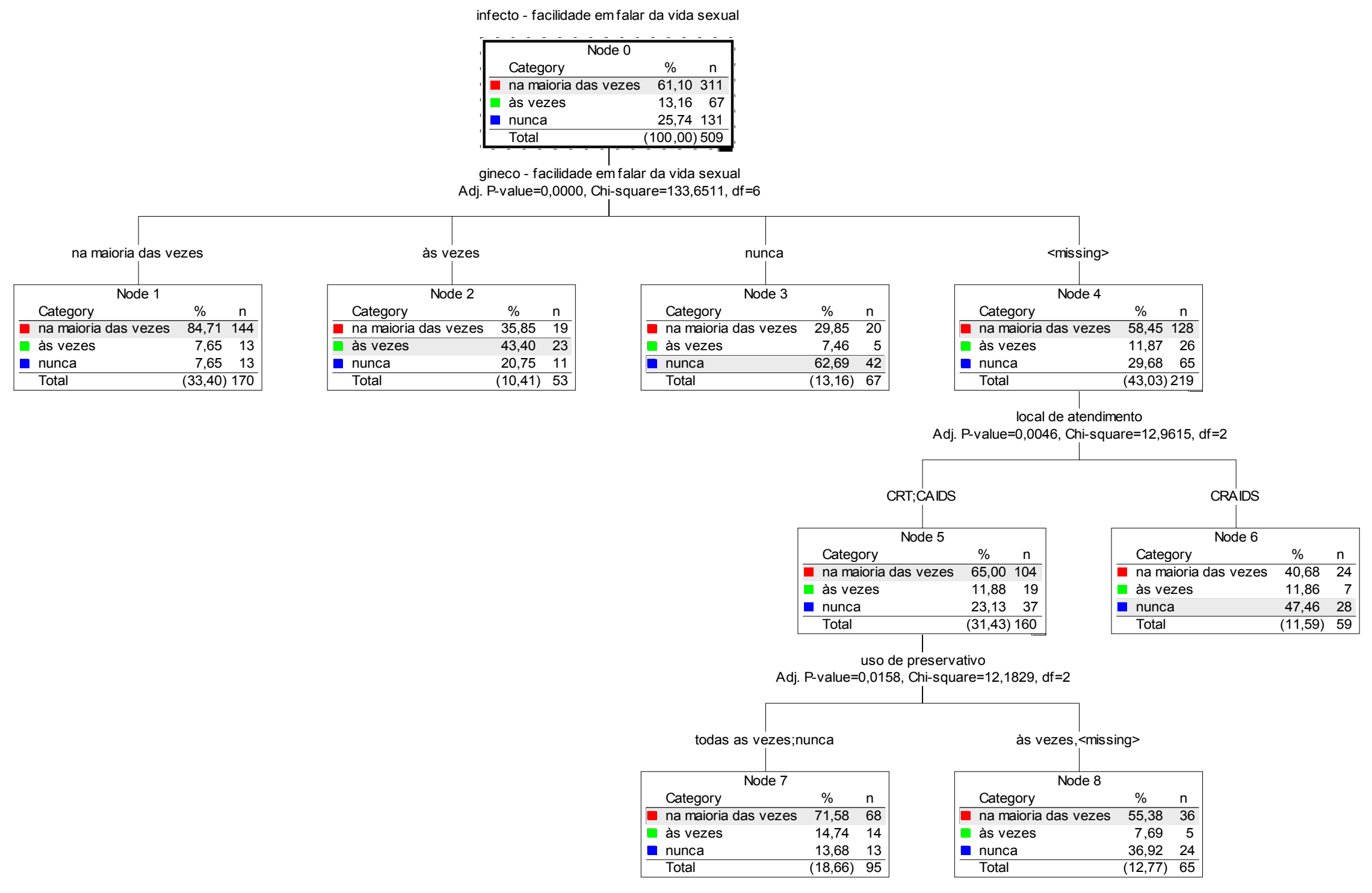


O objeto "facilidade em falar sobre sua vida sexual com o ginecologista" foi analisado com vistas nos seguintes predicados:

- faixa etária;

- nível de escolaridade;

- renda individual mensal;

- renda familiar per capita mensal;

- contribuição individual para a renda familiar;

- número de filhos soropositivos;

- número de pessoas que cuida;

- número de parceiros sexuais durante a vida;

- tipo de parceria atual;

- condição sorológica do parceiro;

- uso de preservativo;

- pensa em ter filhos;

- tempo de infecção diagnosticada;

- informação sobre transmissão durante a gravidez;

- informação sobre prevenção de reinfecção;

- informação sobre terapia anti-retroviral;

- facilidade em entender o que o infectologista diz;

- facilidade em falar sobre suas preocupações e tirar dúvidas com o infectologista;

- facilidade em falar sobre sua vida sexual com o infectologista;

- facilidade em entender o que o ginecologista diz;

- facilidade em falar sobre suas preocupações e tirar dúvidas com o ginecologista;

- contagem de células TCD4;

- significado do exame de CD4;

- significado do exame de carga viral.

No modelo gerado para as mulheres negras foram observadas 3 partições. A primeira dividiu o grupo em virtude da facilidade em falar sobre o assunto com o infectologista. Nessa fase da análise derivaram 2 grupos apresentados nas ramificações 1 (mulheres com alguma dificuldade em falar sobre a vida sexual com o 
infectologista) e 2 (mulheres que não haviam abordado o assunto com 0 infectologista ou que relatavam facilidade em falar sobre o mesmo). Da ramificação 1 surgiram os segmentos 3 e 4, norteados pela facilidade em tirar dúvidas com o ginecologista, enquanto da ramificação 2 surgiram os segmentos 5 e 6 , norteados pelo serviço de saúde especializado em que as mulheres eram acompanhadas.

Grande parte das mulheres atendidas na CAIDS ou no CRT e que na maioria das vezes falavam sobre a vida sexual com o infectologista relataram facilidade em fazê-lo também com o ginecologista $(84,11 \%)$, sendo importante destacar que neste grupo foi identificada maior freqüência relativa de mulheres que relatavam abertura para a orientação em sexualidade. Para aquelas que eram acompanhadas no CRAIDS também prevaleceu a facilidade de comunicação com o ginecologista, porém em menor proporção (55,22\% na maioria das vezes; $25,37 \%$ nunca; $19,40 \%$ às vezes).

Em relação às mulheres dos ramos 3 e 4, encontraram-se em melhor situação comunicacional aquelas que relataram abertura para falar sobre o assunto com o infectologista. Embora entre elas ainda prevalecesse a situação de nunca ter facilidade em falar - 42,70\% dos casos -, a proporção daquelas que relataram facilidade na maioria das vezes foi maior (21,35\% contra 4,29\%) (Figura 22). 
Figura 22. Fatores estatisticamente relacionados à facilidade descrita por mulheres negras vivendo com HIV/AIDS para falar sobre sua vida sexual com o ginecologista. São Paulo, 2000.

gineco - facilidade em falar da vida sexual

\begin{tabular}{|lcr|}
\hline Nategory & $\%$ & $\mathrm{n}$ \\
\hline nunca & 34,83 & 116 \\
na maioria das vezes & 44,74 & 149 \\
às vezes & 20,42 & 68 \\
\hline Total & $(100,00)$ & 333 \\
\hline
\end{tabular}

infecto - facilidade em falar da vida sexual

Adj. P-value $=0,0000$, Chi-square $=119,5826, d f=2$

nunca;às vezes

\begin{tabular}{|c|c|c|c|}
\hline \multicolumn{4}{|c|}{ Node 1} \\
\hline & Category & $\%$ & $\mathrm{n}$ \\
\hline$\overline{0}$ & nunca & 57,23 & 91 \\
\hline [ & na maioria das vezes & 13,84 & 22 \\
\hline [ & às vezes & 28,93 & 46 \\
\hline & Total & $(47,75)$ & 159 \\
\hline
\end{tabular}

gineco - facilidade em tirar dúvidas

Adj. P-value $=0,0005$, Chi-square $=19,1555, \mathrm{df}=2$

na maioria das vezes

\begin{tabular}{|lcc|}
\hline \multicolumn{1}{l}{$\mathrm{N}$} & & \\
Category & $\%$ & $\mathrm{n}$ \\
\hline nunca & 42,70 & 38 \\
na maioria das vezes & 21,35 & 19 \\
às vezes & 35,96 & 32 \\
\hline Total & $(26,73)$ & 89 \\
\hline
\end{tabular}

às vezes;nunca, $<$ missing $>$

\begin{tabular}{|lrr|}
\hline Category & Node 4 & \\
\hline nunca & \multicolumn{1}{c|}{$\%$} & \multicolumn{1}{c|}{ n } \\
\hline na maioria das vezes & 75,71 & 53 \\
às vezes & 20,00 & 14 \\
\hline Total & $(21,02)$ & 70 \\
\hline
\end{tabular}

na maioria das vezes, $<$ missing $>$

\begin{tabular}{|lcr|}
\hline \multicolumn{1}{|c|}{ Node 2} & & \\
\hline Category & $\%$ & $\mathrm{n}$ \\
\hline nunca & 14,37 & 25 \\
\hline na maioria das vezes & 72,99 & 127 \\
às vezes & 12,64 & 22 \\
\hline Total & $(52,25)$ & 174 \\
\hline
\end{tabular}

local de atendimento

Adj. P-value $=0,0004$, Chi-square $=17,8324, \mathrm{df}=2$

\begin{tabular}{|c|c|c|c|c|c|c|}
\hline \multicolumn{3}{|l|}{ CRAIDS } & \multicolumn{4}{|c|}{ CAIDS;CRT } \\
\hline \multicolumn{3}{|l|}{ Node 5} & \multicolumn{4}{|c|}{ Node 6} \\
\hline & $\%$ & $\mathrm{n}$ & & Category & $\%$ & $\mathrm{n}$ \\
\hline & 25,37 & 17 & $\bar{\square}$ & nunca & 7,48 & 8 \\
\hline as vezes & 55,22 & 37 & $\square$ & na maioria das vezes & 84,11 & 90 \\
\hline & 19,40 & 13 & & às vezes & 8,41 & 9 \\
\hline
\end{tabular}


No grupo das mulheres não negras foram as variáveis independentes "facilidade em falar sobre a vida sexual com o infectologista" e "facilidade em tirar dúvidas com o ginecologista" que se apresentaram como fatores preditores, conforme ilustrado na Figura 23.

Dessa análise foram geradas 4 ramificações. No subconjunto 1 foram reunidas as mulheres que relataram facilidade em falar com o infectologista sobre sua vida sexual; no subconjunto 2 foram reunidas as mulheres não negras que não haviam falado sobre o assunto com o infectologista e aquelas que relataram algum tipo dificuldade em abordá-lo. No subgrupo 3 (derivado do ramo 1) estavam as mulheres que não haviam passado por consulta com o ginecologista, não haviam tentado esclarecer suas dúvidas com o mesmo e aquelas que haviam relatado facilidade em ter suas dúvidas solucionadas e, no subgrupo 4 (também derivado do ramo 1), estavam as mulheres que haviam relatado alguma dificuldade em tirar dúvidas com o ginecologista.

No segmento 2 estava grande parte das mulheres que relataram nunca ter facilidade em falar da vida sexual com o ginecologista (47 num universo de 67). Para as mulheres com facilidade em tirar dúvidas com o ginecologista, abordar assuntos relacionados à sua vida sexual foi muito mais fácil, como descrito em $92,42 \%$ dos casos. Um quadro diferente foi apresentado no subgrupo 4 onde 33,33\% das mulheres relataram nunca ter facilidade e $23,53 \%$ relataram ter facilidade em algumas das vezes. 
Figura 23. Fatores estatisticamente relacionados à facilidade descrita por mulheres não negras vivendo com HIV/AIDS para falar sobre sua vida sexual com o ginecologista. São Paulo, 2000.

gineco - facilidade em falar da vida sexual

\begin{tabular}{|c|c|c|c|}
\hline \multicolumn{4}{|c|}{ Node 0} \\
\hline & Category & $\%$ & $\mathrm{n}$ \\
\hline $\bar{\square}$ & na maioria das vezes & 58,56 & 171 \\
\hline$\square$ & às vezes & 18,49 & 54 \\
\hline 口 & nunca & 22,95 & 67 \\
\hline & Total & $(100,00)$ & 292 \\
\hline
\end{tabular}

infecto - facilidade em falar da vida sexual

Adj. P-value $=0,0000$, Chi-square $=82,1997, \mathrm{df}=2$

na maioria das vezes

\begin{tabular}{|lcr|}
\hline \multicolumn{3}{|c|}{ Node 1} \\
Category & $\%$ & \multicolumn{1}{c|}{$\mathrm{n}$} \\
\hline na maioria das vezes & 78,69 & 144 \\
às vezes & 10,38 & 19 \\
nunca & 10,93 & 20 \\
\hline Total & $(62,67)$ & 183 \\
\hline
\end{tabular}

gineco - facilidade em tirar dúvidas

Adj. $P$-value $=0,0000$, Chi-square $=55,6008, \mathrm{df}=2$ às vezes;nunca,<missing $>$

\begin{tabular}{|lcc|}
\hline \multicolumn{1}{|c}{ Node 2} & & \\
Category & $\%$ & $\mathrm{n}$ \\
\hline na maioria das vezes & 24,77 & 27 \\
\hline às vezes & 32,11 & 35 \\
\hline nunca & 43,12 & 47 \\
\hline Total & $(37,33)$ & 109 \\
\hline
\end{tabular}

na maioria das vezes, $<$ missing $>$

\begin{tabular}{|lrr|}
\hline Category & \multicolumn{1}{c}{ Node 3} & \multicolumn{1}{c}{$\mathrm{n}$} \\
\hline na maioria das vezes & 92,42 & 122 \\
\hline às vezes & 5,30 & 7 \\
nunca & 2,27 & 3 \\
\hline Total & $(45,21)$ & 132 \\
\hline
\end{tabular}

às vezes;nunca

\begin{tabular}{|lcl|}
\hline Category & Node 4 & \\
\hline na maioria das vezes & 43,14 & 22 \\
\hline às vezes & 23,53 & 12 \\
nunca & 33,33 & 17 \\
\hline Total & $(17,47)$ & 51 \\
\hline
\end{tabular}




\subsection{Síntese dos Resultados da Análise Multivariada}

As variáveis preditoras para cada um dos objetos estudados, segundo raça/cor das mulheres entrevistadas, estão dispostas no Quadro 2.

No tocante a razão da testagem, embora prevalecesse a testagem por solicitação do serviço de saúde para ambos os grupos de raça/cor, a proporção de mulheres negras nessa situação foi maior e, neste grupo, aquelas que se perceberam em risco tiveram a iniciativa de fazer o teste também em menor proporção que as não negras.

Em relação ao aconselhamento pré-teste, ao comparar os resultados obtidos segundo a raça/cor das entrevistadas, foi possível observar que mais mulheres negras que não negras testadas em UBS, serviços especializados ou COAS, e que não sabiam que estavam sendo testadas, deixaram de receber orientação ou ainda a receberam em grupo. No ambiente de hospital, maternidade, laboratório, banco de sangue ou leite, as situações de cuidado inadequado foram relatadas de forma semelhante; entretanto, é importante ressaltar que esses espaços foram citados menos por negras que por não negras.

Ao contrastar os dados referentes à atitude do profissional no momento da entrega do resultado descritos por mulheres negras e não negras é necessário esclarecer que, enquanto para as não negras o fator estatisticamente relacionado à atitude do profissional é a forma com que ele (ou outro profissional) conduziu o aconselhamento pré-teste, para as negras a importância desse fator sofre influência da consciência que a mulher tem sobre seu risco de ser infectada pelo HIV.

Foi importante observar que, em relação à sensação despertada no momento da entrega do resultado, o padrão de divisão dos grupos apresentou semelhanças, mas a distribuição interna não. Em suma, as mulheres não negras tenderam a relatar mais sensações negativas que apoio/atenção, diferente das negras.

Para as mulheres negras, o tempo que demorou em procurar o serviço de saúde especializado esteve diretamente relacionado ao tempo de infecção diagnosticada e ao fato de elas divulgarem o resultado do exame aos familiares mais próximos e aos filhos. Aquelas que o fizeram rapidamente, iniciaram o acompanhamento num período menor de tempo. 
Quadro 2. Fatores estatisticamente relevantes para o estudo das variáveis dependentes relacionadas ao cuidado de mulheres negras e não negras vivendo com HIV/AIDS

\begin{tabular}{|c|c|c|}
\hline \multirow[t]{2}{*}{ Variável Dependente } & \multicolumn{2}{|c|}{ Variáveis Preditoras } \\
\hline & Mulheres negras & Mulheres não negras \\
\hline a) Razão da testagem & - percepção de risco & - percepção de risco \\
\hline b) Aconselhamento pré-teste & - local da testagem & - local da testagem \\
\hline $\begin{array}{l}\text { c) Atitude do profissional que } \\
\text { entregou o resultado do teste }\end{array}$ & $\begin{array}{l}\text { - aconselhamento pré-teste } \\
\text { - percepção de risco }\end{array}$ & - aconselhamento pré-teste \\
\hline $\begin{array}{l}\text { d) Sensação despertada no } \\
\text { momento da entrega do } \\
\text { resultado }\end{array}$ & $\begin{array}{l}\text { - atitude do profissional que } \\
\text { entregou o resultado do teste } \\
\text { - via de exposição ao vírus }\end{array}$ & $\begin{array}{l}\text { - atitude do profissional que } \\
\text { entregou o resultado do teste }\end{array}$ \\
\hline $\begin{array}{l}\text { e) Tempo que demorou em } \\
\text { procurar um serviço de saúde } \\
\text { especializado }\end{array}$ & $\begin{array}{l}\text { - tempo de infecção } \\
\text { diagnosticada } \\
\text { - tempo que demorou em contar } \\
\text { o resultado à família } \\
\text { - tempo que demorou em contar } \\
\text { o resultado aos filhos }\end{array}$ & $\begin{array}{l}\text { - tempo de infecção } \\
\text { diagnosticada } \\
\text { - } \text { atitude do profissional que } \\
\text { entregou o resultado do teste } \\
\text { - } \text { sensação despertada no } \\
\text { momento da entrega do } \\
\text { resultado }\end{array}$ \\
\hline $\begin{array}{l}\text { f) Uso de preservativo } \\
\text { masculino após o diagnóstico }\end{array}$ & $\begin{array}{l}\text { - condição sorológica do } \\
\text { parceiro atual } \\
\text { - número de pessoas que cuida }\end{array}$ & $\begin{array}{l}\text { - facilidade em obter o } \\
\text { preservativo no serviço onde é } \\
\text { atendida }\end{array}$ \\
\hline $\begin{array}{l}\text { g) Facilidade em obter outros } \\
\text { remédios além do coquetel }\end{array}$ & - local de atendimento & $\begin{array}{l}\text { - local de atendimento } \\
\text { - tipo de parceria sexual atual }\end{array}$ \\
\hline $\begin{array}{l}\text { h) Facilidade em entender o que } \\
\text { o infectologista diz }\end{array}$ & $\begin{array}{l}\text { - facilidade em tirar dúvidas } \\
\text { com o infectologista } \\
\text { - escolaridade }\end{array}$ & $\begin{array}{l}\text { - facilidade em tirar dúvidas } \\
\text { com o infectologista } \\
\text { - renda individual mensal }\end{array}$ \\
\hline $\begin{array}{l}\text { i) Facilidade em falar sobre sua } \\
\text { vida sexual com o } \\
\text { infectologista }\end{array}$ & $\begin{array}{l}\text { - facilidade em falar sobre sua } \\
\text { vida sexual com o } \\
\text { ginecologista }\end{array}$ & $\begin{array}{l}\text { - facilidade em falar sobre sua } \\
\text { vida sexual com o } \\
\text { ginecologista } \\
\text { - local de atendimento } \\
\text { - uso de preservativo masculino } \\
\text { após o diagnóstico de infecção }\end{array}$ \\
\hline $\begin{array}{l}\text { j) Facilidade em entender o que } \\
\text { o ginecologista diz }\end{array}$ & $\begin{array}{l}\text { - facilidade em tirar dúvidas } \\
\text { com o ginecologista } \\
\text { - local de atendimento }\end{array}$ & $\begin{array}{l}\text { - facilidade em tirar dúvidas } \\
\text { com o ginecologista }\end{array}$ \\
\hline $\begin{array}{l}\text { k) Facilidade em falar sobre sua } \\
\text { vida sexual com o } \\
\text { ginecologista }\end{array}$ & $\begin{array}{l}\text { - facilidade em falar sobre sua } \\
\text { vida sexual com o } \\
\text { infectologista } \\
\text { - facilidade em tirar dúvidas } \\
\text { com o ginecologista } \\
\text { - local de atendimento }\end{array}$ & $\begin{array}{l}\text { - facilidade em falar sobre sua } \\
\text { vida sexual com o } \\
\text { infectologista } \\
\text { - facilidade em tirar dúvidas } \\
\text { com o ginecologista }\end{array}$ \\
\hline
\end{tabular}


Para as não negras o tempo de infecção diagnosticada também foi importante, porém a procura do serviço especializado variou em virtude da combinação entre tempo de diagnóstico e qualidade do aconselhamento pré-teste; e tempo de diagnóstico e sensação despertada pela atitude do profissional que entregou o resultado do teste. Demoraram menos para iniciar o tratamento aquelas que receberam alguma orientação antes do teste. Demoraram mais aquelas que relataram sensações negativas diante da ausência do aconselhamento pós-teste ou de sua realização inadequada.

A adesão ao uso do preservativo por parte das mulheres negras foi maior entre aquelas que tinham parceiro sabidamente soronegativo para HIV. Entre as demais, embora o uso consistente predominasse, o uso inconsistente foi maior entre aquelas que eram responsáveis pelo cuidado de mais de 3 pessoas. Entre as não negras, a prática preventiva variou com a facilidade ou não em obter o recurso no serviço onde a mulher era acompanhada: para aquelas que tinham facilidade, poucas não usavam; entre aquelas que relatavam dificuldade em obtê-lo também foi mais freqüente o não uso.

Em relação à obtenção de outros remédios além do coquetel, as mulheres negras atendidas na CRAIDS apresentaram menos facilidade em receber os medicamentos que aquelas atendidas no CRT e na CAIDS. Situação contrária foi observada para as mulheres não negras, sobretudo aquelas que relataram vínculo estável com parceiro sexual.

As possibilidades de "entender o que o infectologista diz", no que se refere às mulheres negras, estiveram relacionadas às possibilidades de com ele solucionar as dúvidas e à escolaridade da entrevistada. Apresentaram mais facilidade de entendimento as mulheres mais escolarizadas que, na maioria das vezes, tiveram suas dúvidas solucionadas na conversa com o especialista. Para as não negras, o quadro foi semelhante, tendo aumentado a proporção de mulheres que entendiam o que o infectologista dizia à medida que aumentava a renda individual.

Quando o assunto era a vida sexual, as negras tinham maior facilidade quanto maior fosse a facilidade em conversar sobre o mesmo assunto com o ginecologista. Para as não negras foi observado algo semelhante; no entanto, foi interessante notar que as mulheres atendidas no CRAIDS apresentaram mais dificuldade em falar sobre 
a vida sexual com o infectologista, e aquelas atendidas no CRT ou na CAIDS tinham mais ou menos facilidade dependente da adesão ao uso de preservativo. Para aquelas que relatavam prática casual de sexo protegido, as dificuldades em falar sobre o assunto eram maiores.

$\mathrm{Na}$ relação estabelecida entre as mulheres negras e o ginecologista , tinham mais facilidade em entendê-lo aquelas que na maioria das vezes tiravam suas dúvidas com ele e aquelas atendidas no CRT ou CAIDS. Quando o assunto estava relacionado à vida sexual, o CRT e a CAIDS continuavam sendo os serviços onde os profissionais eram mais abertos, fossem infectologistas ou ginecologistas; contudo, as maiores dificuldades foram observadas para aquelas que não falavam sobre sua vida sexual com o infectologista e que não tiravam suas dúvidas com o ginecologista.

Para as mulheres não negras, a "facilidade em entender o que o ginecologista diz" variou conforme a possibilidade de com ele solucionar suas dúvidas e, no tocante à conversa sobre a vida sexual, as mulheres não negras que falavam sobre o assunto com o infectologista e que tiravam suas dúvidas com o ginecologista, encontravam-se em melhor situação; seguindo a mesma lógica, aquelas que não conseguiam estabelecer uma conversa desse teor com o infectologista também apresentavam maiores dificuldades em abordar o tema com o ginecologista. 


\section{DISCUSSÃO}

\subsection{Limites e Possibilidades de Erro}

$\mathrm{Na}$ tentativa de garantir a qualidade das evidências produzidas no programa ECI-Brasil foram controlados os elementos que potencialmente funcionariam como fonte de erros.

\subsubsection{Delineamento ou desenho da investigação}

O estudo observacional de corte transversal ou seccional propicia uma descrição instantânea da freqüência de certos atributos dos indivíduos que compõem uma população definida. Tem sido o mais empregado na epidemiologia moderna, sobretudo por sua rapidez e possibilidade de obtenção de resultados imediatos (Almeida Filho, 1989). As recomendações pertinentes a esse tipo de desenho foram seguidas em relação à definição de uma amostra representativa da população de mulheres atendidas nesses serviços; ao instrumento; à seleção e treinamento da equipe responsável pela coleta de dados.

\subsubsection{Amostragem}

A amostra de casos consecutivos consiste em eleger indivíduos que cumpram os critérios de seleção dentro de um intervalo de tempo específico ou até que se alcance um número previamente estabelecido, sendo avaliada como uma das melhores técnicas não probabilísticas (Hulley e Cummings, 1993). O único problema derivado da utilização dessa técnica de amostragem apresentar-se-ia caso o período de coleta de dados fosse demasiado curto para representar adequadamente todos os fatores sazonais ou outras mudanças que pudessem ser produzidas no tempo, o que não ocorreu neste estudo.

\subsubsection{Instrumentos para coleta de dados}

Os instrumentos mostraram-se adequados aos objetivos propostos pelo grupo de pesquisadores (validade do conteúdo), sobretudo porque derivaram de instrumentos utilizados em pesquisas anteriores (Santos, 1994; Santos e col., 1998; Paiva e col., 1998, 2000; Tunala e col., 2000).

Embora a formulação das questões tenha sido testada em estudo piloto (préteste), persistiram algumas respostas inadequadas atribuídas ao caráter recordatório do instrumento e à subjetividade dos temas abordados. Muitas vezes essa 
subjetividade deixou de ser traduzida nas questões ou não foi bem interpretada nas respostas.

\subsubsection{Entrevistadoras}

As entrevistas foram realizadas por profissionais de saúde do sexo feminino, com experiência no atendimento de pessoas convivendo com HIV/AIDS. O grupo de entrevistadoras foi selecionado e treinado em período anterior ao início do estudo. Foram realizadas 16 horas iniciais de treinamento, onde foram apresentadas informações detalhadas sobre os objetivos, metodologia, aspectos éticos do estudo e sobre os referenciais teóricos a serem utilizados - vulnerabilidade e direitos humanos.

Em momento posterior, as entrevistadoras tiveram acesso aos instrumentos e receberam orientações sobre padronização da aplicação/codificação e sobre a tomada de decisão diante de eventuais problemas. Essa seção de treinamento teve duração de 4 horas.

Durante a realização do estudo, o grupo de entrevistadoras participou de reuniões semanais de supervisão de campo, com duração de 3 horas.

Cada entrevistadora foi orientada a não realizar mais de 2 entrevistas por subperíodo; a registrar todas e quaisquer intercorrências no diário de campo e, em caso de necessidade, foram orientadas a acionar as supervisoras de campo imediatamente. Os serviços eram responsáveis por seu diário de campo, recolhido semanalmente pelas supervisoras. Em cada subperíodo atuavam 2 entrevistadoras.

Embora as entrevistadoras tivessem sido treinadas, foi observada a presença mínima, mas persistente, de respostas registradas de forma incorreta ou incompleta. Tal constatação, no entanto, não anula a validade das informações coletadas.

\subsubsection{Entrevistadas}

As informantes foram selecionadas a partir da consulta agendada com médico infectologista, todos os dias da semana e em todos os períodos de atendimento, de modo que representassem a população atendida no serviço.

\subsubsection{Informação}

O caráter recordatório do instrumento abre a possibilidade de os depoimentos serem reticentes e muitas vezes imprecisos. No entanto, a abordagem padronizada e a 
não indução de respostas aparentemente de difícil lembrança contribuíram para diminuição das possibilidades de erro.

Os esclarecimentos prestados quanto ao não prejuízo no caso de desistência, da impossibilidade ou falta de vontade em responder qualquer uma das questões, possibilitou o estabelecimento de uma relação confiável entre entrevistadora e informante.

Embora alguns dos temas abordados apresentassem forte componente subjetivo, o fato de as informações solicitadas estarem agregadas a momentos marcantes e decisivos da vida das entrevistadas, também contribuiu para que elas recordassem, não mentissem, não baseassem seu depoimento em informações dos outros ou em suposições.

\subsubsection{Método estatístico utilizado para análise multivariada}

De acordo com a literatura internacional e nacional existem algumas limitações para a utilização do método CHAID, a saber: o método só é profícuo para a síntese de dados se o número de observações a serem estudadas for grande o bastante para que o valor da estatística não seja contestado; pelo fato de ser essencialmente análogo a uma análise de regressão stepwise, ele pode apresentar todas as limitações que lhe são características; outro ponto limitante é o fato de que o método pode ser considerado sugestivo, mas não absolutamente definitivo, sobretudo porque os valores do multiplicador de Bonferroni, utilizados para estabelecer os limites de significância dos testes, são aplicados individualmente para cada uma das variáveis independentes. Além disso, a técnica pode apresentar-se "fragilizada" porque a aplicação do algoritmo é realizada de forma seqüencial e não simultânea, como ocorre nos modelos de regressão e nas análises de variância, assim, todos os efeitos identificados o são em seqüência e na dependência dos anteriores (Biggs e col., 1991; Oliveira, 1996).

Entretanto esses mesmos autores afirmam que: 1. a técnica é ideal para o estudo de dados complexos, com alta dimensionalidade e com vários tipos de variáveis, independentemente de sua natureza (se quantitativa ou qualitativa); 2 . sua interpretação pode ser feita, facilmente, por um não especialista; 3. não é necessário que as variáveis preditoras apresentem a mesma natureza ou os mesmos níveis; 4. os valores perdidos (missing values) nas variáveis preditoras podem ser tratados como 
categoria flutuante passível de inclusão nas árvores; 5. se o conjunto de critérios estatísticos for utilizado apropriadamente, a árvore resultante enfatizará os resultados idealmente fortes, sem que haja sobrevalorização das chances; 6. é extremamente útil na identificação dos dados que tendem a ser mais importantes em análises desenvolvidas na ausência de sólidas teorias capazes de discriminar claramente as variáveis que são prováveis preditoras e aquelas que não o são. Em virtude disso tudo e de sua adequação ao objeto do estudo, optou-se por utilizá-la.

\subsubsection{Inferência}

A população estudada representa cerca de $30 \%$ das mulheres atendidas em cada um dos serviços pesquisados. Suas características sociodemográficas e epidemiológicas não diferem das demais, o que possibilita afirmar que as conclusões, elaboradas a partir do presente estudo, são aplicáveis à população de referência, embora o fenômeno estudado possa apresentar alguma variação no tempo, lugar, contexto e de acordo com os sujeitos envolvidos.

\subsubsection{Validade externa}

O grupo de mulheres estudado é representativo das mulheres atendidas nos serviços e o grupo daquelas que se recusaram em participar não difere dos demais, seja em relação à idade, renda ou escolaridade. Não devemos, contudo, desconsiderar a possibilidade das mulheres que deixaram de participar do estudo apresentarem características específicas em relação aos temas abordados.

Embora a pesquisa tenha envolvido elevado número de mulheres, vindas de diversos pontos do estado de São Paulo, atendidas em áreas de alta prevalência de infecção e incidência de casos (Santos e São Paulo capital), sua captação foi feita em serviços de referência para o tratamento/acompanhamento de pessoas vivendo com HIV/AIDS (PVHIV/AIDS). É necessário, portanto, que haja cautela ao generalizar os achados para a população de mulheres portadoras de HIV.

Algumas especificidades dos serviços e das mulheres neles atendidas poderiam modificar o perfil da população de estudo:

- no caso do CRAIDS (Santos), embora o serviço seja referência para toda a baixada santista e não se restrinja ao atendimento de usuários de drogas na categoria de comunicantes, uma possível modificação do perfil poderia advir 
da elevada proporção de mulheres parceiras de usuários de drogas injetáveis nele matriculadas;

- a CAIDS poderia direcionar a captação de PVHIV/AIDS pelo fato de também prestar assistência multidisciplinar aos pacientes do sistema privado de saúde, além de desenvolver atividades de pesquisa, ensino e extensão. Entretanto, a tendência a pauperização das mulheres infectadas pelo HIV ou doentes de aids, as mulheres que, em termos de rendimentos, representam camadas sociais mais privilegiadas não se constituem em exceções dentre os casos notificados;

- o CRT do Programa de DST/AIDS do Estado de São Paulo além de constituir-se, há 15 anos, em um serviço de saúde especializado também se apresenta como pólo capacitador em prevenção, assistência e atendimento ambulatorial e/ou hospitalar. Por essas propriedades poder-se-ia trabalhar com a possibilidade de o serviço aglutinar uma população com características diferentes da população geral; contudo, os dados e análises relativos ao acompanhamento clínico-epidemiológico de seus pacientes divulgados em congressos, seminários, artigos e relatórios internos mostram que sua clientela (masculina ou feminina) é a que possui mais semelhanças com a população em geral e em especial com o perfil dos casos de aids notificados no país;

- as mulheres foram recrutadas todos os dias da semana, em todos os períodos de atendimento, a partir da consulta agendada com o médico infectologista; entretanto, esse cuidado pode não ter anulado a possibilidade de as participantes perceberem a qualidade do cuidado e da assistência que lhes são oferecidos de modo não representativo, dado que são atendidas em locais de referência onde, tanto os recursos materiais como humanos tendem a diferir daqueles presentes nos demais serviços de saúde.

\subsubsection{A opção pela cor auto-referida}

Não obstante os militantes do movimento social negro brasileiro questionem os termos utilizados pelo Estado para classificar os indivíduos quanto à raça/cor, é importante saber que o método de escolha fechada é suficientemente confiável para 
ser utilizado na coleta dados (Oliveira e col. citado por Cunha, 1997; Silva, 1988 citado por Maggie, 1996; Petruccelli, 2002).

São várias as interferências no auto-relato sobre raça/cor (fatores socioeconômicos, engajamento e mobilização política, intencionalidade e formatação da pergunta). Porém, não se pretendeu aqui abordar a formação da identidade de um grupo e suas conseqüências. O intuito do presente estudo foi ressaltar a importância da raça/cor nos estudos sobre desigualdades e iniqüidades em saúde assim como fizeram Berquó e col., (1986); Rosemberg e Pinto (1995); Cunha (1997, 2001, 2002); Berquó (1994, 2001); Lopes (1997); Oliveira (1999, 2001); Perpétuo (2000); Martins (2001) Martins e Tanaka (2000); Chacham (2001), dentre outros.

A classificação racial dos indivíduos muitas vezes pode ser vista como um obstáculo para a análise confiável dos dados e é fato que, tanto no Brasil como em outros lugares do mundo, existem vieses de categorização. A cor (ou pertencimento racial) que alguém se atribui é confirmada ou negada pelo olhar do outro, podendo determinar uma dissonância entre o reconhecimento de si mesmo e o reconhecimento a partir do olhar do outro (Munanga, 1986; Fanon, 1983).

No Brasil, o fator socioeconômico é um dos fortes contribuintes para que as pessoas mudem sua raça/cor. À medida que elevam seu nível socioeconômico, elas tendem a relatar, com menos freqüência, que são pretas, podendo até se apresentar como pardas ou outras derivações semânticas (Berquó e col., 1986; Silva, 1994; Wood e Carvalho, 1994; Pinto, 1996; Guimarães, 1997). Ainda assim, é importante que a classificação seja autodeclarada, porque o maior problema em se considerar a variável raça/cor, como uma categoria analítica, não está em sua forma de classificação propriamente dita e sim nos mecanismos sociais e simbólicos que motivam os sujeitos a optarem por esta ou aquela categoria de cor.

Da população total residente no Brasil em 1991, classificaram-se como brancos $51,6 \%$, como pretos $5,0 \%$, como amarelos $0,4 \%$, como pardos $42,4 \%$ e como indígenas $0,2 \%$. Nos dados censitários de 2000, a distribuição por categoria de cor/raça foi: $53,4 \%$ de brancos, $6,1 \%$ de pretos, $0,5 \%$ de amarelos, $38,9 \%$ de pardos e 4,1\% de indígenas; logo, a população negra brasileira em 2000 correspondia a 45,0\% do total (população autoclassificada preta + população autoclassificada parda). Os 
casos em que a informação sobre cor/raça foi ignorada corresponderam a $0,2 \% \mathrm{em}$ 1991 e $0,7 \%$ em 2000 (Petruccelli, 2002).

Ao comparar um subconjunto de resultados da amostra censitária de 2000 com os dados da população total residente por cor no censo de 1991, esse autor observou uma participação relativamente maior das parcelas da população classificadas como de cor branca e de cor preta e um decréscimo na população de autoclassificada parda. Segundo ele, em nenhuma outra época, desde 1872, verificou-se um crescimento absoluto e relativo tão expressivo para a categoria de cor preta, quanto o observado entre os anos de 1991 e 2000.

Para Maggie (1996), os sistemas classificatórios e seus significados marcam distinções no social, logo, não formam uma essência, pois se apresentam em constante construção.

A hierarquização social por grupos de cor justifica a instalação do ideal de branqueamento (Fanon, 1983; Munanga, 1986; Hasenbalg, 1996), mas não anula os limites classificatórios. Embora muitos pardos tendam a se identificar como brancos e alguns pretos classifiquem-se como pardos, eles dificilmente poderão classificar-se como brancos, assim, a impossibilidade de ocupar outros lugares estabelece um limite, e denuncia a permanência da dicotomia negro versus branco.

\subsubsection{Validade das categorias e terminologia racial adotadas}

Sobre a validade das categorias adotadas para a análise segundo raça/cor é importante considerar que: 1. a opção pela agregação das categorias preto e pardo em uma única não derivou de simples razões metodológicas e sim da constatação de que a mutabilidade da auto-identificação não anula e nem mesmo diminui as diferenças entre mulheres negras e não negras; 2. embora as condições de vida de mulheres brancas, indígenas e de ascendência asiática sejam diferentes, a opção pelo agrupamento foi motivada pela baixa freqüência de mulheres nas categorias de cor amarelas e indígenas $(\mathrm{n}=8)$.

Adicionalmente é importante destacar que a escolha dos termos "negra(s)" e "não negra(s)" foi feita com o objetivo de contrapor as categorias apresentadas por autores que representam os grupos sociais hegemônicos e que, geralmente, comparam os coletivos utilizando a terminologia "branco(s)" e "não branco(s)". 


\subsection{Discutindo os Resultados Encontrados}

\subsubsection{Desigualdades sociais geradoras de vulnerabilidades: características gerais da amostra}

\subsubsection{Raça/cor}

O quadro apresentado neste estudo é muito mais alarmante do que aquele apresentado pela SES-SP (2001). Considerando que não se pretendeu manter um equilíbrio proporcional na participação de negras e não negras na amostra e que muitas das mulheres infectadas são acompanhadas em outros serviços especializados localizados em regiões menos centrais, a quantidade de mulheres negras incluídas representou mais da metade da população, superando as expectativas e confirmando as antigas suposições do movimento de mulheres negras sobre a vulnerabilidade desse grupo à infecção pelo HIV e as afirmações de que as desigualdades sociais com viés racial e de gênero contribuem para a disseminação do vírus.

\subsubsection{Idade}

A probabilidade de as negras serem encontradas nas faixas de 18 a 25 anos, 36 a 45 anos, 56 anos e mais foi maior que a observada para as não negras. Embora isso seja fato, não há deslocamentos, grandes o suficiente, para justificar a existência de condutas ou comportamentos diferenciados por raça/cor.

Nas ações dos serviços de saúde, a sexualidade feminina é vinculada à reprodução, mais especificamente à contracepção, logo, as mulheres que "naturalmente" não se encaixam nessa lógica (jovens que desejam exercer livremente sua sexualidade, mulheres laqueadas ou mulheres menopausadas) são desconsideradas nos programas de educação preventiva. Os efeitos dessa não inclusão são observados nas estatísticas oficiais da aids, as quais mostram que, na última década, os casos de aids vêm aumentado persistentemente entre mulheres de 30 anos e mais (MS, 2002a).

Em que pese a ausência de dados desagregados por raça/cor nas estatísticas oficiais, há que se considerar a possibilidade de as mulheres negras na juventude, na idade adulta ou na velhice encontrarem-se em especial situação de vulnerabilidade: as mais jovens diante da infecção por HIV e as mais velhas pelo adoecimento por aids. 


\subsubsection{Escolaridade}

No tocante à escolaridade, as mulheres negras apresentaram-se marcadamente menos escolarizadas, representando a maioria daquelas que não possuíam instrução formal e daquelas que haviam completado no máximo as 4 primeiras séries do ensino fundamental. A situação apresentada por essas mulheres não surpreendeu, uma vez que, na população brasileira como um todo, o índice de alfabetização das mulheres negras é 12 pontos percentuais menor que o índice de alfabetização das mulheres brancas (Sant'Anna, 2001b).

Ponderando que, desde o final da década de 80, a proporção de casos de aids entre mulheres nos grupos de menor escolaridade já ultrapassava os $70 \%$ e que na região Sudeste as mulheres encontram-se mais expostas ao risco de infecção e adoecimento, quanto menor for o seu nível de escolaridade (Fonseca e col., 2000; MS, 2002a), não seria absurdo supor que nesse grupo estariam sobre-representadas as mulheres negras. Seguindo a mesma lógica e tomando por base o perfil da população brasileira mais escolarizada (IBGE, 2000), a notificação pequena, porém recorrente, de casos entre as mulheres mais instruídas, poderia ser atribuída supostamente às mulheres não negras.

Dessa forma, é fundamental destacar que embora a escolaridade não possa ser apresentada como a variável com maior poder explicativo sobre práticas arriscadas, ela figura como elemento essencial no desencadeamento dos processos de vulnerabilização das mulheres ao HIV/AIDS.

\subsubsection{Moradia e habitação}

Embora as mulheres estudadas tenham relatado características de moradia e habitação melhores do que a maioria da população em situação de pobreza no Brasil, é imperativo destacar que eram negras todas as moradoras de rua; a maioria daquelas que moravam em casa de apoio; grande parte daquelas que habitavam em casas com um número menor de cômodos, fosse em casa de tijolos ou apartamento. Esses dados reiteram as afirmações de que ao longo da história, a presença de características 
indesejáveis ${ }^{9}$ tem-se mantido, de forma sistemática, mais em domicílios cuja pessoa de referência é negra do que nos demais (IBGE, 2000; IPEA, 2001).

Todavia não tenha sido possível obter o número de pessoas por cômodo, não seria absurdo considerar a possibilidade de as mulheres negras habitarem residências com mais alta densidade - condição que sabidamente contribui para a prevalência e disseminação de doenças infecto-contagiosas, além de potencializar situações de violência sexual, física e psicológica (Krieger e Higgins, 2002; Luppi, 2002).

\subsubsection{Ocupação}

O perfil ocupacional das mulheres negras e não negras entrevistadas foi muito semelhante. No entanto, entre as negras foi verificada uma chance discretamente maior do trabalho autônomo, da busca por emprego e da dependência de saláriobenefício (previdência social). Nesse sentido caberia o convite à reflexão sobre o lugar social atribuído às mulheres negras no mercado de trabalho (sobrerepresentadas entre as trabalhadoras domésticas), sobre a exclusão "quase natural" das mulheres negras do mercado em virtude do valor simbólico do item "boa aparência", apresentado comumente nos anúncios de oferta de emprego e sobre a discriminação agravada pela soropositividade para o HIV.

A respeito do significado social da inserção desqualificada e da exclusão do mercado de trabalho, é importante salientar que, para além da deficiência de renda, essas situações podem significar a debilidade da liberdade, das iniciativas e das habilidades individuais, além da perda da auto-estima e da autoconfiança. Como descrito por Santos (2000) e Sen (2000), restrições dessa ordem culminam com o desencadeamento de alterações na saúde física e psicológica.

A discriminação no trabalho e suas conseqüências negativas são destacadas na literatura como motivos principais para que, em geral, as PVHA se afastem de suas atividades (Vermelho e col., 1999; Almeida, 2000; ECI, 2001; Parker e Aggleton, 2001). Assim, há necessidade de estudos e pesquisas que enfoquem os diferenciais raciais nas experiências de discriminação e estigmatização nesse contexto.

\footnotetext{
${ }^{9}$ De acordo com o IPEA e o IBGE são consideradas características indesejáveis: construção da habitação com material não durável; alta densidade; inadequação no sistema de saneamento e abastecimento de água; ausência de energia elétrica e coleta de lixo.
} 
No geral, a discriminação sofrida individualmente é um fator de risco para a qualidade de saúde, e as experiências contínuas de discriminação influenciam na saúde física e mental, especialmente na saúde de negros e negras (Krieger e col., 1993, 1998; Aleluia, 2000; Pinto e col., 2000; Guimarães MAC, 2001; Muniz, 2001; Silva Júnior, 2001; Gee, 2002; Cruz e Pinto, 2002).

\subsubsection{Renda individual e familiar}

As desigualdades salariais existentes entre mulheres e homens negros e mulheres e homens brancos são evidentes (Soares, 2001; INSPIR, 1999; IPEA, 2001) e não seria diferente entre as mulheres estudadas. A inferioridade dos salários medianos das mulheres negras ocupadas foi da ordem de 1 salário mínimo: enquanto na população geral, a mediana da renda individual mensal foi de $\mathrm{R} \$ 387,00$, o valor mediano pago às negras foi de $\mathrm{R} \$ 345,00$ e às não negras $\mathrm{R} \$ 475,00$.

Como a maioria das mulheres entrevistadas era a principal responsável pelo orçamento familiar, as famílias viviam com pouco dinheiro, sobretudo as famílias das mulheres negras: a renda familiar per capita (RFPC) mensal das negras era, em média, R\$730,98 mensais, com mediana de R \$ 500,00. Para as brancas, a RFPC, em média, era de $\mathrm{R} \$ 1.229,41$ mensais, com mediana igual a $\mathrm{R} \$ 800,00$.

A chefia feminina ${ }^{10}$ é tão diversa quanto são os arranjos familiares presentes nas sociedades atuais e, em muitos casos, é comum que a organização familiar contemple diversos núcleos e gerações co-habitando num mesmo domicílio. $\mathrm{Na}$ maioria das vezes, essa chefia foge do tradicional, tanto em relação ao encarregado de prover os recursos financeiros, como em relação ao número de chefes dessa organização (Mendes, 2002).

No presente estudo, embora vivessem com menos dinheiro, as mulheres negras cuidavam de maior número de pessoas, perpetuando, ainda que inconscientemente, o exercício das atribuições assumidas por suas ancestrais desde os primeiros tempos de liberdade.

Em contexto de soropositividade para o HIV, a responsabilidade pelo sustento financeiro e moral dos membros da família pode potencializar vulnerabilidades

\footnotetext{
${ }^{10} \mathrm{O}$ fenômeno da chefia de família vem crescendo em todo o país, principalmente nas áreas urbanas. No final da década de 90 , as mulheres chefes de família chegaram a $26 \%$ e, de acordo com Berquó (2001b), a maioria dos domicílios chefiados por mulheres é do tipo monoparental, com presença marcante de mulheres jovens, não unidas, negras, pobres e menos escolarizadas.
} 
femininas (UNAIDS, 2002a, 2002b; OPAS, 2002). Entretanto, em algum momento da vida, a vivência da chefia pode atribuir uma valorização social imensurável da figura feminina.

Para Hita (2002), que estuda unidades familiares chefiadas por mulheres negras, a centralidade da figura feminina e o exercício da "chefia" permitem que as negras sejam respeitadas por sua imagem e definição, afinal "são mulheres fortes, que não têm medo de nada e de ninguém". No que diz respeito à matrifocalidade, ao mesmo tempo em que a autora ressalta sua influência nos processos de organização familiar de outros grupos de cor, inseridos nas mais diversas realidades políticosociais, não deixa de destacar a essencialidade de seu princípio relacional nas tradições africanas e afrodescendentes.

Ainda que vivam em condições de penúria, as mulheres negras mantêm uma feição própria: são e existem sem pedir licença. Elas vivem seus papéis segundo as possibilidades e oportunidades que lhes são acessíveis e, sobretudo na pobreza, não se deixam abater pelas crises de identidade vivenciadas por mulheres brancas ou negras em ascensão social (Teodoro, 1986; Carneiro, 2000; Hita, 2002). Talvez em decorrência dessa "agilidade social" tenham sido pouco freqüentes os relatos de mulheres negras sobre o aumento de despesas após o diagnóstico de infecção pelo HIV.

\subsubsection{Relações intersubjetivas e vulnerabilidades}

Em que pese a nitidez das disparidades raciais discutidas no item anterior, nas próximas secções serão abordadas diferenças sutis (e por vezes mais impactantes), aqui denominadas iniqüidades ${ }^{11}$.

A interação e a sobreposição das dimensões da vulnerabilidade podem ser evidenciadas nos contextos de intersubjetividade que compõem a relação afetivosexual e naqueles que compõem a relação entre o profissional de saúde e a mulher. É esse caráter complexo e multifacetado da vulnerabilidade que se constitui num grande desafio para uma prática comprometida com a justiça.

\footnotetext{
11 Ao termo iniqüidade no processo saúde-doença-cuidado atribui-se o significado: desigualdade superável num dado contexto histórico e social.
} 


\subsubsection{A intersecção das trajetórias individuais: categorias de exposição ao HIV e motivos para a realização do teste}

As categorias de exposição descritas pelas mulheres estudadas, independentemente do grupo de raça/cor, não diferiram daquelas apresentadas nas estatísticas oficiais da aids (MS, 2002), sobressaindo a exposição sexual.

\section{O caminho da exposição sanguínea: o uso de drogas injetáveis}

A interação estabelecida entre uso de drogas e infecção por HIV foi evidenciada entre as mulheres envolvidas neste estudo: daquelas que relataram infecção por via sanguínea, a maioria era UDI. As negras com escolaridade igual ou inferior ao ensino fundamental completo fizeram-se mais freqüentes entre as UDIs que as não negras com o mesmo grau de instrução.

O uso de drogas injetáveis e o compartilhamento de seringas e agulhas contaminadas, desde o início da epidemia, estiveram atrelados a um contexto de más condições de vida, a pessoas com baixa escolaridade, pouca informação, acesso restrito a recursos preventivos e com dificuldades em adotar ou manter práticas redutoras de danos e riscos, e não foi diferente para as mulheres estudadas.

Os autores Paxton e col. (2002) afirmam que, embora as circunstâncias socioeconômicas e o uso abusivo de álcool ou de drogas ilícitas tenham sido apontados como fatores associados ao aumento das chances de risco de infecção sexual por HIV em mulheres, o nível de predição de cada um dos fatores varia de acordo com o grupo racial ou étnico considerado.

No Brasil a relação que o sistema jurídico, os profissionais de saúde e os membros da sociedade em geral têm com os consumidores de drogas ilícitas é tensa, tende a ser pior nas camadas menos favorecidas e entre os negros (Araújo Lima, 1997; Lima e col., 2002). Há poucos anos, o uso de drogas ilícitas passou a ser visto como um problema de saúde pública, contudo, a repressão aos usuários ainda impera entre os operadores da lei e entre os profissionais de saúde (Mesquita e Seibel, 2001; Mesquita, 2003).

Em virtude da repressão, do isolamento, da invisibilidade do problema, da discriminação, da estigmatização atribuída à prática e de sua associação com as transgressões/contravenções masculinas; a prevenção primária ou secundária entre as mulheres é insípida no geral e inexistente na perspectiva racial. Nesse sentido é 
premente a constatação de que a secundarização das questões relacionadas ao uso de drogas, cuidado e assistência em saúde, influencia o curso da vida dos usuários em geral, mas assume proporções maiores e mais prejudiciais na população negra do sexo feminino.

\section{Relações sexuais desprotegidas: um atalho para a infecção}

Desde 1998, a categoria de transmissão sexual é responsável pela grande maioria dos casos notificados entre mulheres. A partir daí, as mulheres deixaram de figurar como usuárias de drogas e passaram a ocupar o lugar de "parceiras de usuários". Entre as subcategorias de exposição sexual, a parceria com UDI é mais comum que a parceria com "homem(ns) pouco conhecido(s)" (MS 1998, 2000, 2002a, 2002b).

No presente estudo, a categoria sexual de exposição ao HIV esteve estatisticamente associada à variável raça/cor, destacando-se que a vulnerabilidade das mulheres negras à infecção por HIV pela via sexual teve seu padrão modificado de acordo com a escolaridade.

Em que pese a ausência de significância estatística foi possível notar que, para as mulheres negras, em todos os estratos de escolaridade, prevaleceu a relação desprotegida com parceiro infectado por outra mulher; no entanto, à medida que aumentava o nível de escolaridade, diminuía o desconhecimento da via de infecção do parceiro e aumentava a freqüência da categoria "relação desprotegida com parceiro UDI ou com parceiro(s) pouco conhecido(s)". Entre as mais instruídas, a proporção de contaminação por parceiro(s) infectado(s) por outra mulher e parceiro(s) UDI(s) foi igualmente alta.

Para as não negras, o quadro foi diferente: independentemente do nível de escolaridade, poucas desconheciam a categoria de exposição do parceiro e a exposição ao vírus em relações desprotegidas com parceiro infectado por outra mulher ou com parceiro UDI foram igualmente altas.

Assim é possível afirmar que, entre as mulheres negras, as redes sexuais (e as práticas não protetivas) envolvendo parceiros casuais ou UDIs eram tecidas pelas mais instruídas, diferente das experiências relatadas por não negras.

As sanções sociais e os rituais típicos dos usuários de drogas e daqueles com quem se estabelece relações sexuais podem incluir trocas materiais e simbólicas que 
não contemplam a proteção, seja no uso dos equipamentos destinados à injeção da droga, seja nas relações sexuais. São comuns a essa cultura tanto as trocas de sexo por drogas, como a relação com múltiplos parceiros, ainda que eles sejam desconhecidos (Bastos, 1996).

Outro fato importante no mundo das drogas é a marginalização e a incorporação do estigma pelos próprios usuários (autodiscriminação). Ao incorporar a noção de "fora da lei", o homem pode optar por não divulgar suas práticas de uso à parceira, contribuindo fortemente para o aumento de sua vulnerabilidade e da vulnerabilidade dela.

A relação sexual com parceiro eventual é reconhecida, por muitos, como uma prática com risco mais facilmente identificável, tanto que $63,3 \%$ dos homens e $69,2 \%$ das mulheres que mantêm relações eventuais exclusivas protegem-se usando preservativo (MS/CEBRAP, 2000); porém, cada relação sexual representa uma interação social, um contexto intersubjetivo especial e único. Muitas vezes, em nome dessa unicidade, os atores abrem mão do preservativo e assumem o risco (ainda que inconscientemente). Forma-se então um abismo preenchido por uma vulnerabilidade quase intrínseca ao exercício da sexualidade e da vida, que se mistura com romantismo, prazer, aventura, falta de recursos materiais ou simbólicos imediatamente disponíveis.

\section{No silêncio do lar}

Muitas vezes no espaço doméstico a mulher torna-se cúmplice indulgente da conduta do marido e age como se tudo fosse possível, desde que não revelado (Roso, 2000). Essas normas e valores sociais, "naturalmente" absorvidos e acatados, com certeza colaboraram para o aumento da vulnerabilidade das mulheres estudadas à infecção por HIV, sobretudo aquelas que sequer faziam idéia da forma como o parceiro havia sido contaminado, aquelas que não sabiam se a infecção do parceiro derivara de relações sexuais com pessoas do mesmo sexo ou do sexo oposto ao dele. Muitas vezes, as raras oportunidades de diálogo não permitem a abordagem de tal tema, reforçando assim a idéia de que a vulnerabilidade é anterior ao risco.

Em paralelo, ao avaliar que a mulher não tem buscado sua autonomia emocional diante do companheiro ou ainda que ela não tenha sido capaz de demandar comportamentos diferentes por parte do outro, pode-se julgar 
erroneamente uma relação que, durante todo o tempo, esteve pautada na crença de fidelidade e amor. Por estranho que possa parecer, na modernidade, o valor social atribuído ao amor e à parceria afetivo-sexual também pode funcionar como potencializador das vulnerabilidades.

Apresentados a seguir, os motivos para a realização do teste reiteram a dificuldade (ou relutância) das mulheres perceberem-se em risco, bem como a secundarização do seu autocuidado.

\section{Iniciativa própria}

Atualmente, em todo o país, independentemente da escolaridade, classe de renda e região onde vive, a população tem um grau considerável de conhecimento sobre as formas de transmissão e prevenção da aids (BENFAM, 1999; MS/CEBRAP, 2000; MS, 2002a, 2002b). Porém, a difusão do conhecimento, a apropriação por parte dos sujeitos e a elaboração de representações sobre aquilo que é informado são componentes ativos de um mesmo processo, cujo delineamento (e concretização) ocorrem em etapas não simultâneas.

A noção de risco individual de infecção pelo HIV ganha diferentes significados de acordo com os sujeitos e os fatores que compõem sua história, suas redes sociais, seus recursos materiais, educacionais e culturais, sua época e o espaço territorial e humano que ocupam, sua geração, sexo e raça.

De forma bem ilustrativa, neste estudo foi observado que, embora as mulheres tivessem conhecido seu diagnóstico sorológico há pouco tempo (4,36 anos em média), grande parte não tinha percepção de seu risco de infecção pelo HIV. Ainda assim, a variável "percepção de risco ${ }^{12}$ " mostrou-se estatisticamente relevante para a análise multivariada do objeto "razão do teste". Para aquelas que se viam em risco, a decisão de fazer o teste foi mais freqüente que para as demais.

Nas entrelinhas dos números pôde-se observar que a proporção de mulheres que se percebiam em risco e que tomaram a decisão de realizar o teste foi maior entre as não negras que entre as negras.

Ao detalhar o nível de análise foi possível notar que, dentre as mulheres que tomaram a iniciativa de fazer o teste, muitas referiam o risco individual como mola

\footnotetext{
${ }^{12}$ A variável denominada "percepção de risco" deriva da pergunta: "antes de fazer o teste você chegou em algum momento a achar que podia ser HIV positivo?" (Anexo IV, questão 47).
} 
propulsora da decisão. Essa referência foi citada por $60 \%$ das mulheres negras com ensino fundamental $1 ; 60 \%$ das negras com ensino médio e superior e por $80 \%$ daquelas que tinham ensino fundamental 2 (dados não apresentados). Entre as não negras, esse motivo foi citado similarmente, independente do grau de instrução.

A parceria sexual com parceiro sabidamente soropositivo também foi utilizada como justificativa para o teste realizado por iniciativa própria, sendo mais freqüente entre as negras, especialmente aquelas com ensino igual ou inferior ao fundamental 1. Entre as não negras, essa justificativa foi menos citada (dados não apresentados no corpo do trabalho).

A consciência do risco, o conhecimento sobre a aids e até mesmo o envolvimento com parceiros sabidamente soropositivos não são traduzidos em medidas preventivas primárias, como o uso do preservativo, mas funcionam como estimuladores da realização do teste. Dentre as mulheres estudadas que fizeram o teste por iniciativa própria, $12,3 \%$ o fizeram porque se relacionavam com parceiros sabidamente soropositivos. Tal paradoxo também foi apresentado por Vermelho e col. (1999); Almeida (2000) e Luppi (2002).

Segundo as autoras, ao incorporar a idéia de que a aids pode não ser mais a “doença do outro", as pessoas são mobilizadas para a mudança de atitude, o que não significa que haja adesão ao preservativo. Dessa forma acaba sendo lógico pensar que, se os caminhos da prevenção primária não foram percorridos, deve existir uma possibilidade de prevenção às conseqüências indesejáveis da infecção já adquirida.

Outro dado recorrente neste e em outros estudos é a decisão em realizar o teste por "precaução". Muitas mulheres que mantinham relacionamento estável, decidiram fazer o teste porque sabiam que a chance de estarem infectadas dependia, em última instância, do comportamento e das atitudes de seu parceiro sexual. No presente estudo, esse motivo foi referido mais por mulheres não negras.

\section{Solicitação do serviço de saúde}

Historicamente os médicos relutam em identificar sintomas corriqueiros à síndrome em suas pacientes "comuns", ainda que sua ocorrência seja persistente. Muitos profissionais, seguindo as crenças leigas, entendem que o diagnóstico de uma IST é capaz de alterar a "saúde da família". Ao deixar de referir as categorias de exposição aos agentes infecciosos, eles perdem a chance de instrumentalizar as 
mulheres para reconhecer as circunstâncias em que se estabelecem os processos de adoecimento e para elaborar estratégias úteis e eficientes para o enfrentamento do problema.

Ao agir com reticência ou omissão, os profissionais desconsideram a interrelação estabelecida entre as infecções de transmissão sexual, deixam de verificar as possibilidades de infecção por HIV e, caso a mulher já seja portadora do HIV, o diagnóstico tardio retarda a adoção de medidas terapêuticas e contribui para o comprometimento de sua qualidade de vida (Parker e Galvão, 1996; Diniz e Villela, 1999; Vermelho e col., 1999; UNAIDS, 1998, 2000, 2002a, 2002b; Guimarães, 1996, 2001; OPAS, 2002).

Posturas inadequadas contribuem para a coincidência entre diagnóstico de infecção e adoecimento: no elenco dos motivos pelos quais o serviço de saúde solicitou o teste, o adoecimento foi o mais citado por mulheres negras e por mulheres não negras.

O diagnóstico de infecção também esteve muito ligado ao fato de a mulher ser mãe de alguém doente ou recém-diagnosticado, seguindo a tendência nacional, mas alertando para a possibilidade de baixa cobertura e resolutividade dos programas de pré-natal e deficiência do programa de diagnóstico nas maternidades. De acordo com as orientações do MS, durante o pré-natal todas as mulheres deveriam ser orientadas quanto à importância da realização do teste e, uma vez diagnosticadas, deveriam ser orientadas quanto à importância da medicação e quanto à redução das possibilidades de infecção da criança caso todas as recomendações fossem seguidas corretamente, mas nem sempre isto acontece (Marques e col., 2002).

\subsubsection{Mudando (ou não) o rumo da história: vida sexual após o diagnóstico}

\section{Atividade sexual}

A maioria das mulheres relatou vida sexual ativa e uso de preservativo após o diagnóstico. Algumas afirmaram que o diagnóstico modificou a qualidade da vida sexual, ora para melhor, ora para pior. Os sentidos e os significados que as pessoas atribuem à infecção por HIV definem, em última instância, a forma como elas conduzirão sua história de vida após descobrirem-se portadoras.

As mulheres infectadas por seus parceiros estáveis, muitas vezes interpretam a doença como conseqüência do comportamento errado do companheiro e isso pode 
conduzi-las ao isolamento afetivo-sexual. Como relataram Rodrigues (1997) e Alves e col. (2002) há quem negue a possibilidade de novamente relacionar-se com o “culpado pelo seu mal". O medo de contaminar o parceiro soronegativo ou de divulgar sua condição sorológica; a preocupação com possíveis questionamentos (e com uma possível rejeição) quando da sugestão do preservativo; as dificuldades em enfrentar o medo de engravidar (ou em assumir o desejo pela gravidez), a dificuldade em lidar com as novas formas que o corpo ganha, com a diminuição do desejo e com a depressão, dificultam a manutenção de vínculos antigos e o estabelecimento de novos.

\section{É namoro ou amizade?}

Dentre aquelas que mantiveram atividade sexual após o diagnóstico, algumas estavam sem parceiro no momento da entrevista (mais negras que não negras). No que se refere às mulheres negras, é importante salientar que a informação de apartação afetivo-sexual não deriva de uma associação estrita com sua condição sorológica.

A ideologia do racismo e a discriminação definem os descaminhos vividos pelos corpos negros femininos e evidenciam que muitas mulheres se retraem por se sentirem insatisfeitas com os traços ou marcadores físicos que lhe são típicos. No entanto, para além da baixa auto-estima, alguns autores afirmam que muitas mulheres negras encontram-se sozinhas por serem preteridas no mercado conjugal (Berquó, 1988,1991; Petruccelli, 2001; Costa, 2002).

Ainda sobre o isolamento de mulheres negras há quem afirme que elas se retraem por problemas relacionados ao ato sexual - falta de desejo, falta de prazer e constante sensação de insatisfação - (Cruz, 1992) e outros que relatam que elas se isolam após terem sido vítimas de violência doméstica praticada por homens conhecidos (White, 2000; Rufino, 2000).

No momento da entrevista, as mulheres estavam envolvidas prioritariamente em relações estáveis. Grande parte morava com o parceiro e, em sua maioria, ambos tinham conhecimento sobre a condição sorológica do outro.

O ato de "contar o resultado ao parceiro" no âmbito coletivo pode significar o comprometimento familiar. No âmbito mais individual (e não menos coletivo), ele pode ser sinônimo de comprometimento emocional, moral ou financeiro. Por conta 
disso, a revelação do diagnóstico persiste como um problema, sobretudo nas relações estáveis.

Ainda, no tocante à revelação, outra especificidade foi revelada no presente estudo: embora tenha sido pequeno o número de mulheres que deixaram de criar oportunidades para falar sobre sua condição sorológica ao parceiro, quase todas eram negras. Mais uma vez as histórias de mulheres negras soropositivas mostram-se diferentes nos pequenos detalhes.

\section{Uso do preservativo}

A adesão ao uso do preservativo por parte das mulheres negras foi maior entre aquelas que tinham parceiro sabidamente soronegativo. Entre as demais, embora o uso consistente predominasse, o uso inconsistente foi maior entre aquelas que eram responsáveis pelo cuidado de mais de 3 pessoas $^{13}$.

Entre as não negras, a prática preventiva variou com a facilidade ou não em obter o recurso no serviço onde era acompanhada: dentre aquelas que tinham facilidade, poucas não o usavam; de modo oposto e complementar, dentre aquelas que relatavam dificuldade em obtê-lo, uma parcela considerável não fazia uso do preservativo.

Nos casos de sorodiscordância, o uso do preservativo pode ser encarado como o único meio de proteção do outro ou como a única forma de não revelar sua condição sorológica ou de postergar essa decisão.

Entre os casais soroconcordantes, a prática de sexo protegido previne a reinfecção, a gravidez indesejada e contribui para uma resposta mais oportuna das terapias medicamentosas e do próprio sistema imunológico (na ausência ou presença de anti-retrovirais). Contudo, ao mesmo tempo em que as vantagens do sexo protegido entre parceiros soropositivos são elencadas, a cumplicidade, o respeito e a fidelidade - que se apresentam como alicerce da relação - impedem o estabelecimento de uma barreira física entre os dois seres.

\footnotetext{
${ }^{13}$ Os termos consistente e inconsistente estão relacionados à freqüência no uso do preservativo nas relações sexuais, assim o uso consistente é sinônimo de "todas as vezes" e o uso inconsistente é sinônimo de "às vezes" ou "nunca".
} 
No conjunto, todas as mulheres sofrem com a dificuldade de introduzir o preservativo na vida sexual porque, na verdade, os riscos atribuídos às experiências corporais de mulheres soropositivas fazem parte de um substrato social, cultural e econômico. As negras, ao depararem com menos facilidade em se proteger, reiteram suas experiências pessoais e singulares de exclusão ou de uma inserção menos individual e mais coletiva, na medida em que têm maior responsabilidade de zelar pelo bem estar da família e menos oportunidades de realizar o autocuidado. Nos caminhos "alternativos" de vida na soropositividade, elas são obrigadas a selecionar uma hierarquia de riscos a serem enfrentados. Diante do desafio de hierarquizar, o sexo desprotegido, ainda que traga conseqüências indesejáveis, nem sempre é visto como a preocupação mais importante.

\subsubsection{Discriminação racial nas práticas de saúde: realidade ou ilusão?}

\section{Conversa anterior à testagem}

De modo especial, a vulnerabilidade feminina ganha novos incrementos diante das demandas relacionadas à experiência de viver com o HIV/AIDS e aos direitos humanos. A noção de direitos é histórica e sua construção se estabelece, de modo gradual, à medida que se travam lutas por novas liberdades contra velhos poderes (Bobbio, 1992). O caráter universal, indivisível, interdependente e interrelacionado dos direitos humanos determina que todos merecem igual respeito e proteção, a todo tempo e em todas as partes do mundo onde se encontrem (Comparato, 1999). Por isso, embora o instrumento para coleta de dados seja limitado para avaliar como as mulheres percebem o respeito aos seus direitos, pôdese destacar algumas das prerrogativas estabelecidas em documentos e tratados internacionais e indicar as situações em que elas deixaram de ser efetivadas.

No presente trabalho, 103 mulheres não sabiam que estavam sendo testadas. Dentre aquelas que sabiam, mais da metade não recebeu aconselhamento prévio e algumas receberam orientação em grupo, especialmente as negras.

$\mathrm{Na}$ análise multivariada, o aconselhamento pré-teste esteve associado ao local da testagem, tanto para as mulheres negras como para as não negras. Mais mulheres negras que não negras testadas em UBS, serviços especializados ou COAS, que não sabiam que estavam sendo testadas, deixaram de receber orientação ou ainda a receberam em grupo. No ambiente de hospital, maternidade, laboratório, banco de 
sangue ou leite, as situações de cuidado inadequado foram relatadas de forma semelhante; entretanto, é importante ressaltar que esses espaços foram citados menos por negras que por não negras.

De acordo com o MS, o aconselhamento prévio à realização do teste deve ser conduzido numa abordagem interativa, com utilização de técnicas que possibilitem ao usuário refletir sobre seus riscos, despertar para as mudanças de comportamento e pensar num possível convívio com a doença; e ao profissional avaliar o estado de mobilização do usuário diante da decisão em realizar o teste.

No caso das mulheres, como a epidemia atinge prioritariamente aquelas que são sexualmente ativas e que estão em idade reprodutiva, a CN-DST/AIDS tem estimulado estratégias de aconselhamento individual e coletivo nos serviços de saúde que prestam atendimento à mulher, notadamente os serviços de planejamento familiar, pré-natal, atendimento ginecológico, maternidades, além dos centros de testagem e orientação.

Em termos de custo-benefício, a estratégia poderia ser considerada interessante, pois, em tese, deveria atender a um grande número de mulheres. $\mathrm{Na}$ prática, ela perde a eficiência porque: 1 . muitas vezes a orientação coletiva anula a individual; 2. durante o pré-natal, muitas mulheres deixam de ser informadas sobre a importância do teste (Marques e col., 2002); 3. por não existir uma integração efetiva entre o programa de saúde da mulher e o programa de DST/AIDS, muitas mulheres são excluídas do processo de orientação, sobretudo aquelas que estão fora da idade reprodutiva, aquelas que optaram por métodos irreversíveis de contracepção e aquelas que não se percebem em risco ou que não têm sua vulnerabilidade percebida pelos profissionais.

Em relação ao diferencial racial identificado, é indispensável enfatizar que, embora todos os cidadãos brasileiros tenham direito aos serviços oferecidos pelo SUS, utilizam-nos apenas os pobres (de acordo com o IBGE, mais de 90\% dos usuários do SUS têm renda familiar per capita mensal média igual ou inferior a 1/2 salário mínimo) ${ }^{14}$.

\footnotetext{
${ }^{14}$ Esses dados referem-se aos serviços públicos de saúde em geral. No caso dos serviços especializados, o perfil do usuário é diferente porque eles passam a ser a melhor opção protetora contra a violação de direitos, inclusive entre aqueles que têm plano de assistência privada.
} 
Considerando representarem os negros a maioria daqueles que vivem na pobreza (cerca de 66\%, segundo o IPEA, 2001), seria lógico pensar que, no mínimo, os serviços públicos de saúde e as pessoas que neles atuam prestassem assistência integral e equânime, independentemente da origem, raça, cor da pele, condição social, sexo ou qualquer outra situação do usuário; mas, na prática, isso também não acontece.

\section{Aconselhamento pós-teste}

Grande parte das mulheres conversou com o profissional de saúde que entregou o resultado do teste. Assim, o foco da discussão será as exceções.

As práticas assistenciais dirigidas às PVHA nem sempre seguem as recomendações da CN-DST/AIDS e os preceitos éticos. De acordo com o MS (2002b), o suporte biopsicossocial deve ser oferecido a todos que se submetem ao teste, antes e depois do diagnóstico, independentemente do resultado.

Nas recomendações sobre o aconselhamento individual pós-teste para sorologia positiva, propõe-se que o processo seja contínuo, com vários agendamentos. Os profissionais são orientados a valorizar o acolhimento emocional, a avaliação do impacto do resultado e a orientação sobre a redução de novos riscos. Quando o diagnóstico é realizado em outros serviços de saúde que não os especializados, as equipes profissionais devem estar capacitadas para oferecer o suporte inicial e indicar serviços de referência para a continuidade do processo.

O acolhimento, a escuta e a orientação oferecidas ao usuário com sorologia positiva para o HIV são essenciais não só para a aderência ao tratamento futuro, mas para amenizar o impacto do diagnóstico; para contribuir no enfrentamento de questões decorrentes da sorologia positiva; para proteger a imagem que o indivíduo desfruta perante a sociedade e a imagem que ele faz de si próprio (auto-estima). No entanto, algumas das mulheres entrevistadas relataram que o resultado foi entregue a outra pessoa e, dentre aquelas que receberam o resultado pessoalmente $(n=925)$, 210 sequer conversaram com o profissional responsável pela revelação do diagnóstico.

Na perspectiva dos direitos humanos, a ausência de orientação sobre a nova condição de vida é tão grave quanto a quebra do sigilo e da confidencialidade em decorrência da entrega do resultado para outra pessoa (MS, 1996, 2002b). 
Ao investigar as representações sociais que justificam e reforçam a violência cultural e simbólica, Ferreira (2000) constatou diferenças nos serviços prestados às PVHA devido à sua condição de classe, aparência, categoria de exposição ao vírus e ao fato de ter ou não aids. Neste estudo, a atitude do profissional que entregou o resultado do teste mostrou-se associada à variável raça/cor e, no modelo multivariado de análise, foi interessante notar que, para as não negras, o fator estatisticamente relacionado à atitude do profissional foi a forma com que ele (ou outro profissional) conduziu o aconselhamento pré-teste - se conversou ou não conversou.

Para as negras, além da variável “conversa anterior à testagem”, também houve influência da consciência que a mulher tinha sobre o risco de ser infectar. Aquelas que não sabiam que estavam sendo testadas e aquelas que não foram aconselhadas antes do teste, mais uma vez tiveram seus direitos violados. As mulheres negras que não se imaginavam em risco também relataram, em grande proporção, a violação do seu direito a informação e orientação sobre a nova condição de vida e de saúde.

À guisa de considerações mais aprofundadas sobre o impacto de atitudes como essas na vida de mulheres que percorreram caminhos diversos para chegar até aquela porção de sua história, caber aqui destacar a importância da humanização dos profissionais que atuam na clínica, prevenção ou assistência e a necessidade da transformação de suas práticas.

\section{Como as mulheres interpretam as atitudes profissionais e o que sentem diante delas?}

O desencadeamento das sensações deriva de uma série de fatores subjetivos, porém não se pode negar a influência dos fatores ambientais e interacionais. É nesse contexto que se constrói a vulnerabilidade individual: só é vulnerável aquele que se relaciona com o outro e que, ao se relacionar, não ocupa posição de igualdade.

Os direitos de "não ser submetido à tortura, penas ou tratamentos cruéis, desumanos ou degradantes" e de "não ser submetido a qualquer discriminação por motivo de raça, cor, sexo, religião, opinião pública ou de outra natureza, origem nacional ou social, situação econômica, nascimento ou qualquer outra situação", descritos, respectivamente, nos artigos $7^{\circ}$ e $26^{\circ}$ do Pacto Internacional de Direitos 
Civis e Políticos ${ }^{15}$ e endossados no inciso III do artigo $5^{\circ}$ da Constituição Federal, deixaram de ser efetivados quando as mulheres declararam ter experimentado sensações desagradáveis tais como indiferença, discriminação, crítica ou acusação no momento da entrega do resultado do teste.

Para as mulheres negras, as sensações foram estatisticamente influenciadas pela "atitude do profissional que lhe revelou o diagnóstico" e pela "via de exposição ao vírus". Entre as negras que não conversaram com o profissional sobre o resultado do teste, prevaleceu a sensação de indiferença. Para aquelas que conversaram com o profissional e que foram infectadas pela via sexual, outras sensações que não apoio e atenção tiveram pouca representatividade; em contrapartida, entre aquelas que foram infectadas pela via sanguínea, aumentou a proporção de desencadeamentos negativos após a conversa com o profissional.

Para as mulheres não negras, a sensação apresentou-se estatisticamente influenciada apenas pela atitude do profissional que entregou o resultado do teste. Como descrito para as negras, entre as mulheres não negras que não conversaram com o profissional predominou a sensação de indiferença. Entre aquelas que receberam orientação prevaleceu a sensação de apoio/atenção, mas, ainda nesse caso, houve referências de indiferença e discriminação.

A discriminação, como ato concreto, é passível de punição perante a lei, especialmente por isso as pessoas tornam-se mais impotentes diante de uma situação não explícita de discriminação do que diante de uma agressão física, pois não encontram apoio para enfrentá-la. Os sofrimentos derivados de atitudes discriminatórias são imensuráveis e, em última instância, violam o direito à saúde (artigo 196 da Constituição Federal) porque podem desencadear danos psíquicos (patologia incluída no conjunto de doenças de classificação internacional).

Não seria impróprio imaginar que a influência estatística da via de exposição ao HIV sobre a sensação despertada pela atitude do profissional pudesse estar baseada em julgamento moral. Partindo do pressuposto de que o imaginário coletivo é construído em um ambiente que exacerba os estigmas, no processo de assimilação entre profissionais e usuárias podem facilmente compartilhar das mesmas crenças e

\footnotetext{
${ }^{15}$ Adotado pela Resolução n ${ }^{\circ}$ 2.200-A da Assembléia Geral das Nações Unidas, em 16/12/1966. Aprovado pelo Decreto Legislativo no 226, de 12/12/1991. Ratificado pelo Brasil em 24/1/1992. Em vigor no Brasil desde 24/4/1992. Promulgado pelo Decreto no 592, de 6/7/1992.
} 
valores: eles criticando ou rotulando antecipadamente as mulheres infectadas no uso de drogas injetáveis como difíceis e "naturalmente" não aderentes; elas visualizando a doença como um castigo, e sua pessoa como real "merecedora" de críticas e acusações.

\section{Por que algumas demoram mais em procurar o serviço de saúde especializado?}

Após a revelação do diagnóstico, a maioria das mulheres procurou o serviço de saúde especializado com rapidez. Porém, ainda que tenha havido um fator comum influenciando o tempo decorrido entre diagnóstico e procura do serviço especializado, o padrão de influência segundo raça/cor foi: entre as negras o tempo de diagnóstico foi combinado ao tempo em que a mulher manteve-se no isolamento em meio a seus familiares mais próximos ou aos seus filhos (inserção mais coletiva); entre as não negras, a interação deu-se entre variáveis mais diretamente ligadas à sua individualidade (experiência de aconselhamento anterior à testagem e sensação despertada diante da atitude do profissional que entregou o resultado do teste).

A herança cultural (crenças, valores e atitudes), os comportamentos preventivos e a qualidade do autocuidado estão diretamente conectados ao espaço físico, social e simbólico que os sujeitos ocupam. Segundo Valongueiro e Campineiro (2002), essa rede de domínios entrelaçados e interdependentes influencia a percepção das necessidades individuais em saúde e, em última instância, determina a decisão do sujeito em procurar ou não um serviço de saúde.

A depender do ano de diagnóstico, a conexão doença-morte era muito freqüente, com isso tanto a ausência de sintomas (e a possibilidade de um erro no diagnóstico) como a sua presença (que deveria ser negada como a única alternativa para se continuar vivendo) motivavam mulheres soropositivas a não procurar $o$ serviço (ou desaparecer dele quando já matriculadas), conforme descrito por Guimarães (2001).

$\mathrm{Na}$ atualidade, os avanços na área terapêutica, a distribuição gratuita de medicamentos e as conquistas no campo dos direitos têm possibilitado uma vida mais longa e de melhor qualidade, contribuindo para que homens e mulheres sintamse menos obrigados a ocultar seu diagnóstico ou, quem sabe, para que eles elaborem novas estratégias para manter oculto o resultado e freqüentem os serviços sem grandes preocupações. O medo, a culpabilidade e a auto-exclusão gerados pela 
doença deixaram de se "utilizar" das pessoas vivendo com HIV/AIDS como seus cúmplices silenciosos. Em virtude de tal superação, a coragem e a vontade de viver têm vencido na maioria das vezes.

Para além das ressignificações do viver com aids, é essencial enfatizar que a qualidade do serviço prestado é a chave para a adesão ao tratamento (Acurcio e Guimarães, 1996; Minayo e col., 1999; MS, 2000, Jesus, 2000; Cornelius e col., 2002).

\section{Informações não recebidas nos serviços especializados}

Incorporada ao referencial de direitos humanos, a noção de saúde é redimensionada. Seu significado passa a ser maior que "estado de normalidade biológica ou ausência de doença", sendo socialmente reconhecida como "conjunto de condições integrais e coletivas de existência, influenciado pelas condições políticas e sócio-econômicas” (Mann e col., 1999; Valongueiro e Campineiro, 2002).

A informação contribui, decisivamente para a percepção sobre saúde e doença, sobre os comportamentos preventivos, a qualidade do autocuidado, a identificação das necessidades e a transformação das mesmas em demandas. Embora no caso da prevenção das IST, incluindo o HIV e a aids, a informação, por si só, não seja suficiente, ela tende a funcionar como um instrumento útil para a minimização dos efeitos negativos de práticas não protegidas.

Muitas mulheres incluídas no estudo foram diagnosticadas após o aparecimento de sintomas da síndrome, logo, a nova condição de vida e de saúde marcava, enfaticamente, a necessidade de informação.

Ainda assim várias mulheres deixaram de ser informadas sobre reinfecção, terapia medicamentosa, transmissão materno-infantil e contracepção, terapia antiretroviral, redução de danos no uso de drogas injetáveis e sobre prevenção em parcerias sorodiscordantes, ou seja, tiveram violado seu "direito de desfrutar o mais elevado nível de saúde física e mental, com ênfase na assistência médica, acesso a serviços, prevenção e tratamento de doenças" (artigo $12^{\circ}$, parágrafos 3 e 4 do Pacto Internacional de Direitos Econômicos, Sociais e Culturais ${ }^{16}$ ) e de "ter acesso a informações que contribuam para assegurar a saúde e o bem-estar da família" (artigo

\footnotetext{
${ }^{16}$ Ver nota anterior.
} 
$10^{\circ}$, parágrafo 8 da Convenção sobre a Eliminação de todas as Formas de Discriminação contra as Mulheres ${ }^{17}$ ).

A centralidade feminina nos processos de ensino-aprendizagem no ambiente familiar é comum em diversas culturas. Nas culturas africanas e afrodescendentes, o papel das mulheres mais velhas na transmissão oral das tradições, valores e normas sociais é fundamental (Carneiro, 2000; Silva e Guimarães, 2000; Ató-Ire, 2002). Diante disso, as mulheres negras com freqüência relatam conhecimentos transmitidos por mulheres de outras gerações, especialmente no que se refere à vida sexual e reprodutiva (Bernardo, 1998; Batista, 1997).

$\mathrm{Na}$ era da aids, as estratégias de educação de pares têm-se mostrado eficientes e eficazes na redução de vulnerabilidades (UNAIDS, 2002a, 2002b; OPAS, 2001), logo, não existiriam motivos que justamente fossem utilizados para negar-lhes o direito à informação. Uma vez informadas, as mulheres poderiam redirecionar o conhecimento adquirido em suas redes de convívio, independentemente de sua condição de usuária de drogas ou "parceira de usuário"; sexualmente ativa ou inativa; grávida, puérpera ou menopausada.

\subsubsection{Relação com o serviço de saúde onde se trata atualmente}

\section{Vale a pena percorrer tão longas distâncias?}

Os serviços especializados no atendimento a DST/AIDS têm-se aperfeiçoado no tocante a acesso e localização, estrutura física e organização, capacitação, distribuição e formação humanizada dos profissionais. Para além dos fatores diretamente relacionados ao fluxograma do serviço, os usuários, especialmente as mulheres, buscam um esquema de atendimento que contemple suas necessidades em saúde e que seja conveniente com o seu perfil socioeconômico, com a posição que ocupam na hierarquia social e de gênero dentro e fora da unidade familiar, com suas crenças, valores e expectativas (geradas a partir do conhecimento da nova condição de saúde).

\footnotetext{
${ }^{17}$ Adotada pela Resolução no 34/180 da Assembléia das Nações Unidas, em 18/12/1979. Aprovada pelo Decreto Legislativo $\mathrm{n}^{\circ}$ 93, de 14/11/1983. Ratificada pelo Brasil em 1/2/1984 (com reservas). Promulgada pelo Decreto n 89.406 , de 20.3.1984.
} 
Nesse sentido é muito comum que as PVHA percorram longas distâncias em busca de atendimento com qualidade e no anonimato, porque, nos serviços localizados nas proximidades de sua residência, aumentariam as possibilidades de serem identificadas, estigmatizadas e discriminadas (Acurcio e Guimarães, 1996; Gomes e col., 1999; Minayo e col.,1999; Tunala, 2002). Entre as mulheres estudadas, elas demoravam em média 1 hora e 10 minutos para chegar ao serviço de saúde, e a maioria delas dependia de transporte coletivo (especialmente as negras).

\section{A importância do trabalho integrado}

Atendidas prioritariamente pelo mesmo médico desde o início do acompanhamento, poucas mulheres relataram atendimento nutricional, atendimento por outro médico que não infectologista ou ginecologista, atendimento odontológico ou psicológico. Pouco mais da metade já havia sido atendida por assistentes sociais ou por enfermeiras e já havia passado em consulta ginecológica.

A atuação de uma equipe multiprofissional nos serviços pressupõe que todos os seus membros reflitam sobre a epidemia e suas conseqüências nas mais diversas realidades. Todavia, a visão de integralidade e intersetorialidade nem sempre está presente nas ações de saúde, especialmente nas ações dirigidas às MVHA. Para elas, o cuidado também continua priorizando o tratamento anti-retroviral e o manejo da doença sem atentar que a melhoria da qualidade de vida depende do cuidado ampliado e de sua valorização como sujeito.

Mais uma vez as mulheres tiveram violado o seu direito de "desfrutar o mais elevado nível de saúde física e mental, com ênfase na assistência médica, acesso a serviços, prevenção e tratamento de doenças". As mulheres negras entrevistadas receberam assistência ginecológica com mais freqüência, mas foram atendidas em menores proporções por odontólogos, outro médico que não o infectologista ou ginecologista, outro profissional que não os anteriormente citados e por nutricionista. Estiveram associadas à raça/cor as variáveis "ter sido atendida por médico ginecologista" e "ter sido atendida por outro médico que não o infectologista ou ginecologista".

Ao medicalizar os corpos femininos e dissociá-los dos sujeitos, os profissionais de saúde cooperam para a não adesão aos cuidados preventivos. Um exemplo dessa prática de retrocesso diz respeito à saúde sexual e reprodutiva: 
embora seja notório que na presença do HIV há mudança na história natural das demais IST, assim, sua duração, infectividade, progressividade e resposta à terapêutica são alteradas podendo acarretar-lhes danos irreparáveis e até mesmo a redução do tempo de vida, como no caso da co-infecção de HIV e HPV de alto potencial oncogênico (Ter Meulen e col., 1992; Wasserheit, 1992; Adimora e col., 1994; Vernon e col., 1994; Coll-Seek e col., 1994; Minkoff e col., 1995; MS, 1998, 2002b), as MVA (e os profissionais que delas cuidam) apresentam-se especialmente vulneráveis à lógica de que o ginecologista só deve ser procurado na presença de um “problema grave” (Fernandes, 1998; Gogna e Ramos, 1999). Ainda sobre o atendimento ginecológico (e não integral), embora o desejo de ter filhos não seja bem acolhido na soropositividade (Paiva e col., 2002; Santos e col., 2002), as mulheres continuam sendo vistas a partir de sua capacidade de reproduzir. Mediante tal realidade, a saúde sexual e reprodutiva só é valorizada na presença de uma gravidez ou diante da necessidade de evitá-la (Villela, 1999; Diniz e Villela, 1999; MS, 2002b).

Outro exemplo da medicalização do corpo está relacionado aos cuidados nutricionais. Embora a adequação e a mudança de hábitos alimentares sejam essenciais para a qualidade de vida das portadoras, o número de nutricionistas integrados à equipe multidisciplinar é sempre pequeno, quando não ausente. Não seria absurdo supor que a locação de recursos para contratação desses profissionais seja priorizada nas equipes hospitalares e que, no caso dos ambulatórios, os recursos sejam realocados, uma vez que a orientação nutricional pode ser feita pelo profissional responsável pelas explicações sobre o uso correto das medicações prescritas.

Adicionalmente, ao pensar em qualidade de vida de MVHA, deve-se pensar na preservação de sua imagem (em seu aspecto físico) e auto-estima (bens juridicamente protegidos segundo a norma do artigo $5^{\mathrm{O}}$ da Constituição Federal, inciso V). A correta intervenção odontológica dentro de um serviço especializado possibilita a promoção desses direitos e do "direito ao mais elevado nível de saúde", uma vez que viabiliza o diagnóstico e intervenção precoce sobre inúmeras doenças relacionadas à aids, bem como a prevenção de alterações na função oral (Gomes e col., 1999; Miranzi e Miranzi, 2000; Zampieri e col., 2000). 


\section{Águas escuras e profundas: os desafios colocados para o bom atendimento}

Resguardando os pontos apresentados nos parágrafos anteriores, os exemplos de humanidade encontrados com freqüência nos serviços de referência confirmam que os profissionais são sensíveis à causa para a qual se dedicam e que, além disso, têm capacidade de fazer uma revisão crítica do seu poder e saber, dispondo-se a dialogar e construir caminhos menos dolorosos de enfrentamento da epidemia. Porém, por mais que seja evidente que, ao permanecer no serviço, a mulher o avalia como positivo e sente-se satisfeita, deve-se salientar que a avaliação do serviço (e de sua qualidade) pode estar baseada na baixa expectativa que ela tem em relação aos serviços públicos em geral.

Como qualquer outra atividade humana, o cuidado cede espaço para atitudes negativas e para tratamentos inadequados (cruéis em sua concepção e execução), como, por exemplo, as mulheres negras entrevistadas tiveram mais facilidade em receber outros medicamentos que não o coquetel de anti-retrovirais, quando eram atendidas no CRT ou na CAIDS. Situação contrária foi observada para as mulheres não negras, sobretudo para aquelas que relataram vínculo estável com parceiro sexual.

Quando o assunto era vida sexual, o CRT e a CAIDS apresentaram-se como os serviços que abrigavam profissionais mais abertos, mais receptivos, fossem os ginecologistas ou infectologistas. $\mathrm{Na}$ comunicação estabelecida entre o(a) infectologista e as mulheres negras, a facilidade em falar sobre a vida sexual esteve diretamente relacionada à facilidade em conversar sobre o mesmo assunto com o(a) ginecologista. Para as não negras foi observado algo semelhante; no entanto foi interessante notar que, além das mulheres atendidas no CRAIDS relatarem mais dificuldade em conversar sobre sua vida sexual, essa possibilidade ainda sofria influencia da variável "uso de preservativo masculino": para aquelas que relatavam usar preservativo às vezes, era maior a dificuldade em falar sobre o assunto.

A distinção e a discriminação das mulheres estudadas não estavam baseadas simplesmente na opinião dos profissionais. Para ilustrar essa afirmação basta considerar que as mulheres negras, as quais apresentaram histórias de vida menos privilegiadas e que se mostraram especialmente vulneráveis em muitos dos aspectos 
estudados, relataram menos freqüentemente facilidade em falar sobre a vida sexual tanto com o infectologista como com o ginecologista.

As atitudes discriminatórias estão inseridas num contexto histórico, cultural e político e são respaldadas pela ideologia que perpassa esse contexto. Como descrito na literatura, muitos profissionais, adeptos da justiça e da eqüidade contribuem, contraditoriamente, para violações sistemáticas de direitos (Mensch, 1993; Santos, 1996; Coelho e Figueiredo, 2000; Ferreira, 2000; Ayres e col., 2000; Guimarães, 2001; Parker e Aggleton, 2001; van Ryn e Fu, 2003).

\section{Em que língua eles estão falando?}

\section{As facilidades (e dificuldades) em entender o que os médicos dizem}

Dentre as mulheres estudadas, a maioria afirmou ter facilidade para falar de suas preocupações e tirar dúvidas com o infectologista e o ginecologista e ter facilidade em entender o que eles dizem; apesar disso, muitas não souberam explicar o significado e a finalidade dos exames de CD4 e de carga viral.

A distância social que separa os médicos da maioria dos usuários geralmente contribui para aumentar suas vulnerabilidades. A inadequação da linguagem, a dificuldade de aproximação com as pessoas e com suas realidades, somadas às dificuldades em abordar outros aspectos da vida que não aqueles, aparentemente relacionados à sua condição clínica, são os principais impeditivos para a ocorrência de uma interação efetivamente positiva (Villela, 1999; Guimarães, 2001; Ayres, 2002). Prova disso é que, para as mulheres negras estudadas, a facilidade em entender o que o infectologista diz esteve relacionada à sua escolaridade e à facilidade de, com ele, solucionar as dúvidas: apresentaram mais facilidade de entendimento as mulheres mais escolarizadas, as quais na maioria das vezes conseguiam solucionar suas dúvidas. Para as não negras, a proporção daquelas que entendiam o infectologista aumentava conforme a renda individual e a facilidade de, com ele, tirar dúvidas.

$\mathrm{Na}$ relação estabelecida entre as mulheres negras e o ginecologista tinham mais facilidade em entendê-lo aquelas que na maioria das vezes tiravam suas dúvidas e aquelas que eram atendidas no CRT ou CAIDS. Para as mulheres não negras, a facilidade em entender o que o ginecologista dizia variou apenas em função da possibilidade de, com ele, tirar dúvidas. 
Ao perder a oportunidade de se fazer entender, os profissionais deixam de contribuir para a melhoria da qualidade de vida da mulher e indiretamente incrementaram sua vulnerabilidade ao adoecimento.

De acordo com Leite e col. (2000), Paiva e col. (2000), Tunala e col. (2000), Lignani Júnior e col., (2001), a adesão é facilitada quando os sujeitos entendem o que está acontecendo com o seu corpo e distinguem as conseqüências da infecção. Ilustrando tal importância, pode ser destacada a relação estabelecida entre o fato de saber o significado e a finalidade dos exames de CD4 e de carga viral: para as mulheres negras, aquelas que detinham a informação correta sobre um exame apresentavam mais chances de também deter a informação correta sobre o outro, sobretudo nos estratos de maior escolaridade. Adicionalmente, aquelas que desconheciam o significado e a finalidade de um dos exames poderiam saber do outro, caso tivessem maior escolaridade.

\section{Em meio a tamanha diversidade, ao final do túnel existirão luzes que conduzam a equidade?}

As inúmeras diferenças e especificidades identificadas para mulheres negras e não negras nos processos de vulnerabilização à reinfecção pelo $\mathrm{HIV}$ e ao adoecimento por aids levam a crer que, ao final do túnel, deve-se encontrar várias luzes, pois uma só contribuiria para a manutenção da uniformidade do cuidado.

$\mathrm{Na}$ vida, as pessoas interagem dentro de uma lógica político-social assim, e mesmo que os procedimentos sejam padronizados, é fundamental que suas histórias de vida sejam consideradas em todos os aspectos, e que profissionais, direta ou indiretamente ligados ao cuidado, estejam aptos a abordá-los e a gerenciar os possíveis conflitos advindos dessa abordagem.

As vivências da soropositividade refletem ou dimensionam o espaço social que os sujeitos ocuparam ao longo de suas vidas. Para as mulheres negras vivendo com HIV/AIDS, o fato de nunca terem sido vistas como membros de um segmento historicamente espoliado acirra suas vulnerabilidades. Não é possível uniformizar os diferentes sem incorrer na possibilidade de cometer injustiças, logo, para que os contextos sociais mais profundos sejam abordados, é preciso compreender os caminhos e descaminhos da busca pela eqüidade; é preciso haver 
mobilização/disposição para as ações transformadoras e sensibilidade/humanidade para a promoção da dignidade e de uma vida menos vulnerável. 


\section{CONSIDERAÇÕES FINAIS E RECOMENDAÇÕES}

A história da epidemia de aids entre as mulheres tem inúmeras particularidades e, ao incorporar raça como categoria analítica, foi possível identificar que as heterogeneidades da vida com HIV são transpassadas por construções históricas, culturais, políticas e ideológicas, que antecedem a aquisição do vírus.

Ao qualificar a vulnerabilidade como algo multidimensional, instável e assimétrico, exige-se que as ações de atenção às pessoas vivendo com HIV/AIDS ultrapassem os limites da proteção individual, da motivação do sujeito em acompanhamento, da motivação dos profissionais de saúde direta e indiretamente envolvidos no processo. Embora haja uma preocupação com a aplicação racional de recursos, para o alcance de uma razão favorável entre custo e efeito e entre risco e benefício, é necessário que também haja uma preocupação com a intervenção sobre os fatores estruturais que determinaram e determinam essa ou aquela condição de saúde.

Ao identificar os vieses raciais nos processos de vulnerabilização das mulheres à reinfecção pelo HIV ou adoecimento por aids, todos (pesquisadores, ativistas, administradores, gestores e profissionais de saúde e educação em saúde e até mesmo as próprias mulheres) devem estar conscientes de sua coresponsabilidade, seja porque em algum momento omitiram ou negaram as implicações diretas e indiretas das desigualdades raciais somadas às desigualdades de gênero, seja porque atribuíram às mulheres negras um status "quase natural" de vítima.

Para que os serviços de saúde não contribuam para a manutenção da violência estrutural e cultural contra as pessoas vivendo com HIV/AIDS, especialmente as mulheres negras, recomenda-se que haja um investimento no desenvolvimento institucional, com ênfase na formação continuada dos profissionais e na humanização do cuidado.

No processo de formação continuada recomenda-se que:

- sejam apresentados dados sobre as disparidades raciais em saúde, especialmente no campo da aids e, para isso, recomenda-se que a variável "raça/cor" sirva de base para a construção das estatísticas da aids da mesma 
forma que são utilizadas as variáveis "sexo", "idade", "escolaridade", "ocupação";

- todos os profissionais sejam capacitados a identificar situações de opressão e marginalização com base no pertencimento racial ou outra situação;

- todos os profissionais sejam motivados a reconhecer que as desvantagens materiais e simbólicas acumuladas pela população negra, e pelas mulheres em especial, são importantes catalisadores de vulnerabilidades;

- em todos os níveis, os programas de formação continuada de profissionais contemplem aspectos técnicos, éticos e de comunicação interpessoal relacionados ao manejo de questões relativas à raça e gênero;

- os profissionais das áreas técnicas e administrativas sejam formados para compreender a relevância da autodeclaração sobre raça/cor e que, uma vez conscientes da importância da informação, sejam capacitados a coletá-la.

Para que as ações de atenção sejam delineadas na perspectiva da integralidade e da eqüidade e, para que as mulheres não sejam expostas a situações que desrespeitam sua dignidade e seus direitos, recomenda-se que:

- em todos os locais onde o teste é oferecido sejam implementadas as normas técnicas de aconselhamento pré e pós-testagem, com garantia de cumprimento de todas as premissas estabelecidas em seus conteúdos;

- sejam ampliados os mecanismos de participação dos sujeitos diretamente beneficiados pelas ações;

- toda e qualquer abordagem profissional não seja coercitiva e não vitimize os sujeitos;

- toda e qualquer abordagem profissional respeite as identidades individuais e coletivas, os valores culturais, as crenças religiosas, as representações sobre a pessoa, saúde, doença e cura apresentadas pelas mulheres;

- toda e qualquer abordagem profissional contemple as diversidades raciais, geracionais, de classe, orientação sexual e estilo de vida;

- toda e qualquer abordagem profissional fortaleça ou contribua para a reconstrução de identidade(s) e auto-estima;

- toda e qualquer abordagem profissional desencadeie processos de conscientização e ampliação do repertório de direitos (empoderamento); 
- as equipes multiprofissionais estejam capacitadas a identificar as necessidades e demandas específicas das pessoas e dos grupos atendidos, sobretudo no que diz respeito a sexualidade, conjugalidade, revelação do diagnóstico e prevenção de reinfecção;

- haja integração entre as especialidades médicas, sobretudo entre ginecologia e infectologia;

- sejam estabelecidas articulações intersetoriais eficientes para contemplar as necessidades e demandas específicas que extrapolam as áreas de atuação do serviço de saúde, sobretudo no que diz respeito a educação, trabalho, moradia e defesa de direitos;

- sejam elaboradas e implementadas ações em saúde integral, saúde sexual e reprodutiva dirigidas aos parceiros, de modo que seus repertórios simbólicos e histórias de vida sejam valorizados e que sejam contempladas discussões sobre relações raciais, relações de gênero e estilo de vida;

- seja garantido à mulher o acesso às informações precisas e em linguagem adequada sobre transmissão do HIV na gravidez, no parto, amamentação; prevenção em parcerias sorodiscordantes; reinfecção pelo HIV; uso mais seguro de drogas; uso de métodos contraceptivos adequados e evolução clínica da doença;

- seja garantido à mulher o acesso, pleno e contínuo, a medicamentos utilizados no controle das infecções oportunistas;

- seja garantido à mulher o acesso, pleno e contínuo, aos preservativos masculino e feminino e às informações sobre sua utilização;

- em todas as abordagens educativas haja o compromisso de orientar as mulheres (e seus parceiros) para a importância de consultas periódicas com outros profissionais, que não os médicos infectologistas;

- a comunicação interpessoal seja eficientemente estabelecida entre o profissional e a mulher de modo que, no momento do atendimento, elas possam sentir-se acolhidas e contempladas em relação às suas dúvidas e preocupações, sobretudo no que diz respeito à evolução clínica da doença, à terapia medicamentosa, ao exercício livre, prazeroso e seguro da sexualidade. 
Enfim, para que sejam reduzidas (quiçá erradicadas) as iniqüidades no cuidado oferecido às mulheres negras e não negras vivendo com HIV/AIDS, recomenda-se que sejam construídos novos espaços de interlocução, onde se reconheçam as especificidades, vontades e desejos do outro e se busque encontrar algo perto do ideal, para ambas as partes. 


\section{REFERÊNCIAS BIBLIOGRÁFICAS}

Acurcio FA e Guimarães MDC. Acessibilidade de indivíduos infectados pelo HIV aos serviços de saúde: uma revisão de literatura. Cadernos de Saúde Pública 1996; 12(2).

Adimora AA, Hamilton H, Holmes KK, Sparting PF. Sexually Transmitted Diseases. 2.ed. Singapore: Companion handbook/International Editions; 1994.

[AIDSCAP]. Family Health International. Harvard School of Public Health. Joint United Nations Programme on HIV/AIDS. The status and trends of the global HIV/AIDS pandemic symposium final report 1996 July 5-6; Vancouver, Canada.

Aleluia R. Minha história em saúde mental. In: Werneck $J$ et al., orgs. O livro da saúde das mulheres negras: nossos passos vêm de longe. Rio de Janeiro: Pallas; 2000. p. 167-170.

Almeida CCL. Risco e saúde reprodutiva: a percepção dos homens de camadas populares. Cadernos de Saúde Pública 2002; 18(3): 797-805.

Almeida Filho N. Epidemiologia sem números: uma introdução crítica à ciência epidemiológica. Rio de Janeiro: Campus; 1989.

Almeida TR. O segurado da previdência social portador de HIV/AIDS sob a ótica do médico perito. In: Anais do I Fórum e II Conferência de Cooperação Técnica Horizontal da América Latina e do Caribe em HIV/AIDS e DST 2000 nov 6-10; v. 2, Rio de Janeiro, Brasil. Brasília: Ministério da Saúde, Secretaria de Políticas de Saúde, Coordenação Nacional de DST/AIDS; 2000. p. 1.041.

Alves RN, Kóvacs MJ, Stall R, Paiva V. Fatores psicossociais e a infecção por HIV em mulheres: Maringá, PR. Rev de Saúde Pública 2002; 36(4 Supl.): 32-39.

Araújo Lima LC. O vício e a violência: o cotidiano do crack e as narrativas do vício; 1997. [Dissertação de Mestrado - Pontifícia Universidade Católica de São Paulo].

Ató-Ire. Mães e pais de santo atuando na promoção da saúde. Bol Inf Projeto Ató-Ire: Religiões Afro-brasileiras e Saúde 2002 nov; Ano I (edição especial).

Ayres JCRM. Práticas educativas e prevenção de HIV/AIDS: lições aprendidas e desafios atuais. Interface Comunicação, Saúde e Educação 2002; 6(11): 11-24.

Repensando conceitos e práticas em saúde pública. In: Parker R e Terto Júnior V, orgs. Aprimorando o debate: respostas sociais frente à AIDS: limites e possibilidades na terceira década. Rio de Janeiro: ABIA; 2002. p. 12-19.

. Sobre o risco: para compreender a epidemiologia. São Paulo: Hucitec; 1997.

. Vulnerabilidade dos jovens ao HIV/AIDS: a escola e a construção de uma resposta social. In: Silva LH, org. A escola cidadã no contexto da globalização. Petrópolis: Vozes; 1998. p. 413-423.

Ayres JCRM; França Júnior I; Calazans GJ, Saletti Filho HS. O conceito de vulnerabilidade e as práticas de saúde: novas perspectivas e desafios. São Paulo; 2003. (mimeo)

Vulnerabilidade e prevenção em tempos de Aids. In: Barbosa R e Parker R, orgs. Sexualidades pelo avesso: direitos, identidades e poder. Rio de Janeiro: IMS/UERJ; São Paulo: Editora 34; 1999. p. 49-72.

Ayres JCRM, França Júnior I, Lopes F. Direitos Humanos e HIV/AIDS: relações entre situações de vulnerabilidade e características do cuidado recebido por mulheres vivendo com HIV/AIDS em serviços de referência no Estado de São Paulo, Brasil. In: Anais do I Fórum e II Conferência de Cooperação Técnica Horizontal da América Latina e do 
Caribe em HIV/AIDS e DST 2000 nov. 6-10; v. 1, Rio de Janeiro, Brasil. Brasília: Ministério da Saúde, Secretaria de Políticas de Saúde, Coordenação Nacional de DST/AIDS; 2000. p. 136.

Barbosa MIS. Racismo e Saúde. São Paulo; 1998. [Tese de Doutorado - Faculdade de Saúde Pública da Universidade de São Paulo]

. É mulher, mas é negra: perfil da mortalidade do "quarto de despejo". Jornal da RedeSaúde 2001 mar 23; p. 34-36.

Barbosa MTS, Byington MRL, Struchiner CJ. Modelos dinâmicos e redes sociais: revisão e reflexões a respeito de sua contribuição para o entendimento da epidemia do HIV. Cadernos de Saúde Pública 2000; 16 (1 Supl.): 37-51.

Barbosa R e Villela WV. A trajetória feminina da AIDS. In: Parker R e Galvão J, orgs. Quebrando o silêncio: mulheres e AIDS no Brasil. Série História Social da AIDS, n. 7, Rio de Janeiro: Relume-Dumará/ABIA/IMS/UERJ; 1996. p. 17-32.

Barbosa RM. Negociação sexual ou sexo negociado? Poder, gênero e sexualidade em tempos de aids. In: Barbosa $\mathrm{R}$ e Parker R, orgs. Sexualidades pelo avesso: direitos, identidades e poder. Rio de Janeiro: IMS/UERJ; São Paulo: Editora 34; 1999. p. 73-88.

Barcelos LC. Educação: um quadro de desigualdades raciais. Estudos Afro-Asiáticos 1992; 23: 37-69.

Barros RP, Henriques R, Mendonça R. Desigualdade e pobreza no Brasil: retrato de uma estabilidade inaceitável. Rev Brasileira de Ciências Sociais 2000; 15(42): 127-141.

Barsted LL e Hermann J. Mulheres negras e indígenas: a lei e a realidade. In: Barsted LL et al., eds. As mulheres e a legislação sobre o racismo. Série Traduzindo a legislação com a perspectiva de gênero, n. 4, Rio de Janeiro: CEPIA; 2001. p. 43-92.

Basset MT. The pursuit of equity in health: reflections on race and public health data in southern Africa [Commentaries]. American Journal of Public Health 2000; 90(11): 1.690-1.692.

Bastos FI. A feminização da epidemia de AIDS no Brasil: determinantes estruturais e alternativas de enfrentamento. Série Saúde Sexual e Reprodutiva, n. 3, Rio de Janeiro: Associação Brasileira Interdisciplinar de Aids; 2001.

Cenas nubladas: a usuária de drogas injetáveis e a epidemia de AIDS. In: Parker R e Galvão J, orgs. Quebrando o silêncio: mulheres e AIDS no Brasil. Série História Social da AIDS, n. 7, Rio de Janeiro: Relume-Dumará/ABIA/IMS/UERJ; 1996. p. 61-78.

Bastos FI e Szwarcwald CL. AIDS e pauperização: principais conceitos e evidências empíricas. Cadernos de Saúde Pública 2000; 16(1 Supl.): p. 65-76.

Batista LE. Há relação entre a raça/etnia e a informação em saúde reprodutiva? Nas trilhas da Pesquisa 1997; 7: 37-54.

Mulheres e homens negros: saúde, doença e morte. Araraquara; 2002. [Tese de Doutorado - Faculdade de Ciências e Letras da UNESP, Araraquara]

[BENFAM] Sociedade Civil Bem-estar Familiar no Brasil. Comportamento e intenções reprodutivas da população masculina. Pesquisa Nacional sobre Demografia e Saúde. Rio de Janeiro: Benfam; 1999.

Bento MA. Institucionalização da luta anti-racismo e branquitude. In: Heringer H., org. A cor da desigualdade: desigualdades raciais no mercado de trabalho e ação afirmativa no Brasil. Rio de Janeiro: IERÊ (Instituto de Estudos Raciais Étnicos); 1999. p 11-30. 
Bernardo T. Memória em branco e negro: olhares sobre São Paulo. São Paulo: EDUC/Editora da UNESP; 1998.

Berquó E. Arranjos familiares no Brasil: uma visão demográfica. In: Schwarcz LM, org. História da vida privada no Brasil: contrastes da intimidade contemporânea. São Paulo: Companhia das Letras, v. 4; 1998. p. 411-437.

. Como se casam negros e brancos no Brasil. In: Lovell PA, org. Desigualdade racial no Brasil contemporâneo. Belo Horizonte: CEDEPLAR; 1991. p. 115-20.

Demografia da desigualdade: algumas considerações sobre os negros no Brasil. In: Anais VI Encontro Nacional de Estudos Populacionais 1988; v. 3, p. 89-110.

Esterilização e raça em São Paulo. Rev Brasileira de Estudos Populacionais 1994; 11(1): 19-26.

Importância dos estudos sobre a população negra (entrev). Jornal da RedeSaúde 2001a mar 23; p. 7-10.

Perfil Demográfico das Chefias Femininas no Brasil [Apresentado no Seminário Estudos de Gênero face aos Dilemas da Sociedade Brasileira, promovido pelo III Programa Relações de Gênero na Sociedade Brasileira da Fundação Carlos Chagas; 2001b mar,13-16; Itu].

Berquó E, Bercovichi AM, Garcia EM. Estudo da dinâmica demográfica da população negra no Brasil. Textos NEPO 9. Campinas: NEPO/UNICAMP; 1986.

Berquó E, Pinho MD, Lopes F, Oliveira KA, Lima LCA. A População Negra Brasileira frente ao HIV/AIDS: Uma Proposta de Treinamento em Pesquisa para Pesquisadores Negros. [Relatório Semestral de Atividades apresentado à Fundação MacArthur]. São Paulo: CEBRAP; 2001. (mimeo)

Bhopal R. Racism in medicine: The spectre must be exorcised [news]. British Medical Journal 2001; 322(23): 1.503-1.504.

Biggs D, De Ville B, Suen E. A method of choosing multiway partitions for classification and decision trees. Journal of Applied Statistics 1991; 18(1): 49-62.

Bobbio N. A era dos direitos. São Paulo: Campus; 1992

Brito AM, Castilho EA, Szwarcwald CL. AIDS e infecção pelo HIV no Brasil: uma epidemia multifacetada. Rev da Sociedade Brasileira de Medicina Tropical 2000; 34(2): 207-217.

Broman, CL. The health consequences of racial discrimination: a study of African Americans. Ethnicity and Disease 1996, 6: 148-153.

Buchalla CM. A síndrome da imunodeficiência adquirida e a mortalidade masculina, de 20 a 49 anos, no Município de São Paulo, 1993 a 1986. São Paulo; 1993. [Tese de Doutorado - Faculdade de Saúde Pública da Universidade de São Paulo]

. Aids: o surgimento e a evolução da doença. In: Monteiro CA (org.). Velhos e Novos Males da Saúde no Brasil: a evolução do país e de suas doenças. São Paulo: Hucitec/NUPENS-USP; 1995. p. 331-345.

Cain VS e Kington RS. Investigating the role of racial/ethnic bias in health outcomes [Editorials]. American Journal of Public Health 2003; 93(2): 191-192.

Caldwel PM. A hair piece: perspectives on the intersection of race and gender. In: Delgado R. e Stefanic J, eds. Critical race theory: the cutting edge. 2. ed. Philadelphia: Temple University Press; 2000. p 275-285. 
Camino L, Silva P, Machado A, Pereira C. A face oculta do racismo: uma análise psicossociológica. Rev Psicologia Política 2001; (1): 13-36.

Carneiro F. Nossos passos vêm de longe... In: Werneck J. et al., orgs. O livro da saúde das mulheres negras: nossos passos vêm de longe. Rio de Janeiro: Pallas; 2000. p. 22-41.

Cashmore E. Dicionário de relações étnicas e raciais. São Paulo: Summus; 2000.

[CDC] Centers for Disease Control and Prevention. HIV/AIDS Surveillance Report. US HIV and AIDS cases reported through June 2001. Midyear edition, v. 13, n. 1; 2001a.

[CDC] Centers for Disease Control and Prevention. HIV/AIDS Surveillance Report. US HIV and AIDS cases reported through December 2001. Year-end edition, v. 13, n. 2; $2001 b$.

Chacham AS. Condicionantes Socioeconômicos, etários e raciais. Jornal da RedeSaúde 2001 mar 23; p. 44-47.

Coelho WF e Figueiredo MAC. Avaliação do atendimento psicossocial recebido por pessoas que vivem com o HIV/AIDS. In: Anais do I Fórum e II Conferência de Cooperação Técnica Horizontal da América Latina e do Caribe em HIV/AIDS e DST 2000 nov 610; v. 2, Rio de Janeiro, Brasil. Brasília: Ministério da Saúde, Secretaria de Políticas de Saúde, Coordenação Nacional de DST/AIDS; 2000. p. 932.

Coll-Seek A, Faye MA, Critchlow CW, Mbaye AD, Kuypers J, Woto-Gaye G et al. Cervical intraepithelial neoplasia and human papillomavirus infection among Senegalese women seropositive for HIV-1 or HIV-2 or seronegative for HIV. International Journal of Sexually Transmited Diseases and AIDS 1994; 5: 189-193.

Comparato FK. A afirmação histórica dos direitos humanos. São Paulo: Saraiva, 1999. p. $1-55$.

Cornelius LJ, Smith PL, Simpson GM. What factors hinder women of color from obtaining preventive health care? American Journal of Public Health 2002; 92(4): 535-539.

Cruz ICF. Estudo descritivo sobre as características definidoras do diagnóstico de disfunção sexual. Rev Escola de Enfermagem da USP 1992; 26(1):43-64.

Cruz ICF e Pinto AS. Condições para a saúde e o bem-estar? Inquérito sobre as mulheres negras do Estado do Rio de Janeiro [carta]. Cadernos de Saúde Pública 2002; 18(1).

Costa CS. Pirâmide da solidão ou pirâmide dos não-casados? Cor e estado conjugal na terceira idade no Brasil. Encontro Nacional de Estudos Populacionais [CDRom]; 2002 nov 4-8; Minas Gerais, Brasil. Ouro Preto: ABEP, 2002.

Cunha EMGP. Crianças paulistas: diferenças raciais ao nascer e ao morrer. Encontro Nacional de Estudos Populacionais [CDRom]; 2002 nov 4-8; Minas Gerais, Brasil. Ouro Preto: ABEP, 2002.

Condicionantes da mortalidade infantil segundo raça/cor no estado de São Paulo, 1997-1998. Campinas; 2001a. [Tese de Doutorado - Universidade Estadual de Campinas]

Infant mortality and race: the differences of inequality. In: Hogan DJ, org. Population change in Brazil: contemporary perspectives. Campinas: Population Studies Center (NEPO/UNICAMP); 2001b. p. 333-336.

Raça: aspecto esquecido na iniqüidade em saúde no Brasil? In: Barata RB et al., orgs. Equidade e Saúde: contribuições da epidemiologia. Série EpidemioLógica, n. 1, Rio de Janeiro: FIOCRUZ/ABRASCO; 1997. p. 219-234. 
Dallabetta G, Laga M, Lamptey P. Controle de doenças sexualmente transmissíveis: manual de planejamento e coordenação de programas. Rio de Janeiro: Te Corá/ASF; 1997.

Dean AG, Dean JA, Burton AH, Dicker RC. Epi Info, version 6bc: a word processing, database and statistics program for epidemiology on microcomputers. Georgia: Centers for Disease Control and Prevention; 1997.

Delgado R. Words that wound: a tort action for racial insults, epithets, and name-calling. In: Delgado R e Stefanic J, eds. Critical race theory: the cutting edge. 2. ed. Philadelphia: Temple University Press; 2000. p. 131-140.

Delor F e Hubert M. Revisiting the concept of "vulnerability". Social Science \& Medicine 2000; 50: 1.557-1.570.

Diaz ALL. Revelando o oculto cuidar de pessoas idosas: uma proposta para a promoção da igualdade de gênero. In: Blay E, org. Igualdade de Oportunidades para as mulheres: um caminho em construção. São Paulo: Humanitas/FFLCH/USP; 2002. p. 107-120.

Diniz SG e Villela WV. Interfaces entre os programas de DST/AIDS e saúde reprodutiva: o caso brasileiro. In: Parker R et al., orgs. Saúde, Desenvolvimento e Política: respostas frente à aids no Brasil. São Paulo: Editora 34; 1999. p. 123-176.

[ECI] Enhancing Care Initiative. Mulheres e Aids: desafios para os serviços de saúde. Disponível em <URL: http://www.eci.harvard.edu> [2001 Ago 15]

Fanon F. Pele negra, máscaras brancas. Coleção Outra Gente, v. 1, Salvador: Fator; 1983.

Ferreira MPS. Aids: da violência aos direitos humanos à construção da solidariedade. In: Anais do I Fórum e II Conferência de Cooperação Técnica Horizontal da América Latina e do Caribe em HIV/AIDS e DST 2000 nov 6-10; v. 2, Rio de Janeiro, Brasil. Brasília: Ministério da Saúde, Secretaria de Políticas de Saúde, Coordenação Nacional de DST/AIDS; 2000. p. 633.

Fonseca MG, Szwarcwald CL, Derriço M, Andrade CLT, Veras CT, Bastos FI. AIDS e grau de escolaridade no Brasil: evolução temporal de 1986 a 1996. Cadernos de Saúde Pública 2000; 16(1 Supl.): p. 77-87.

França Júnior I, Ayres JCRM, Calazans GJ. Saúde coletiva e direitos humanos: um diálogo possível e necessário. In: Anais do VI Congresso Brasileiro de Saúde Coletiva, 2000 ago 28-set. 3; Salvador, Bahia, Brasil. Instituto de Saúde Coletiva da Universidade Federal da Bahia e Associação Brasileira de Pós-Graduação em Saúde Coletiva; 2000. [CDRom, texto 1981].

Frota-Pessoa O. Raça e eugenia. In: Schwarcz LM, Queiroz RS, orgs. Raça e diversidade. São Paulo: Edusp/Estação Ciência; 1996. p. 29-46.

Gee GC. A multilevel analysis of the relationship between institutional and individual racial discrimination and health status. American Journal of Public Health 2002; 92(4): p. 615-623.

Giami A. Representações e sexualidade: psicologia social e pluridisciplinaridade. In: Loyola MA, org. Sexo e sexualidade na antropologia (A sexualidade nas Ciências Humanas). Rio de Janeiro: Eduerj; 1998. p. 202-225.

Gilbert L e Walker L. HIV/AIDS in South Africa: an overview. Cadernos de Saúde Pública 2002; 18(3): 651-660. 
Gogna M e Ramos S. Crenças leigas, estereótipos de gênero e prevenção de DST. In: Barbosa $\mathrm{R}$ e Parker R, org. Sexualidades pelo avesso: direitos, identidades e poder. Rio de Janeiro: IMS/UERJ; São Paulo: Editora 34; 1999. p. 229-230.

Gollub EL. Human Rights is a US problem, too: the case of women and HIV. American Journal of Public Health 1999; 89(10): p. 1.479-1.482.

Gomes KRO e Tanaka AC. Morbidade referida e uso dos serviços de saúde por mulheres trabalhadoras, Município de São Paulo. Rev de Saúde Pública 2003; 37(1).

Gomes R, Silva CMFP, Deslandes SF, Souza ER. Avaliação da assistência ambulatorial a portadores de HIV/AIDS no Rio de Janeiro, segundo a visando de seus usuários. Cadernos de Saúde de Pública 1999; 15(4).

Goodman AH. Why genes don't count (for racial differences in health). American Journal of Public Health 2000; 90(11): 1.699-1.702.

. The problematics of "race" in contemporary biological anthropology. In: Boaz NT, Wolfe LD, eds. Biological anthropology: the state of the science. Bend: International Institute for Human Evolutionary Research; 1995. p. 149-164.

Guerriero, ICZ. Gênero e vulnerabilidade ao HIV: um estudo com homens na cidade de São Paulo. São Paulo; 2001. [Dissertação de Mestrado - Departamento de Psicologia Clínica da Pontifícia Universidade Católica de São Paulo]

Guerriero ICZ, Ayres JRCM, Hearst N. Masculinidade e vulnerabilidade ao HIV de homens heterossexuais, São Paulo, SP. Rev de Saúde Pública 2002; 36(4 Supl.): 50-59.

Guimarães ASA. Racismo e restrição dos direitos individuais: a discriminação racial "publicizada". Estudos Afro-Asiáticos 1997: 31: 51-78.

. Raça, racismo e grupos de cor no Brasil. Estudos Afro-Asiáticos 1995; 27:45-63.

Guimarães CD. "Mas eu conheço ele!": um método de prevenção do HIV/AIDS. In: Parker R e Galvão J, orgs. Quebrando o silêncio: mulheres e AIDS no Brasil. Série História Social da AIDS, n. 7. Rio de Janeiro: Relume-Dumará/ABIA/IMS/UERJ, 1996. p. 169180 .

Aids no feminino: por que a cada dia mais mulheres contraem aids no Brasil? Rio de Janeiro: Editora UFRJ; 2001.

Guimarães MAC. Vulnerabilidade subjetiva. In: Anais do Seminário A Vulnerabilidade da População Afro-brasileira à Epidemia de HIV/AIDS $2001 \mathrm{dez}$ 10-11; Rio de Janeiro, Brasil; 2001.

Afro-descendência, aids e vulnerabilidade subjetiva. Boletim Internacional sobre Prevenção e Assistência à AIDS 2001 jan-mar; 46 (Encarte Brasil): p. 8-9.

Guimarães MDC. Estudo temporal das doenças associadas à aids no Brasil, 1980-1999. Cadernos de Saúde Pública 2000; 16(1 Supl.): p. 21-36.

Gupta S, Anderson RM, Mary RM. Networks of sexual contacts: implications for the pattern of spread of HIV. AIDS 1989; 3: 807-817.

Habermas, J. Direito e democracia: entre facticidade e validade. v. I. Rio de Janeiro: Tempo Brasileiro; 1997. p. 113-1139.

Harrell JP, Hall S, Taliaferro J. Physiological responses to racism and discrimination: an assessment of the evidence. American Journal of Public Health 2003; 93(2): 243-248. 
Hasenbalg C. Entre o mito e os fatos: racismo e relações raciais no Brasil. In: Maio MC e Santos RV, orgs. Raça, Ciência e Sociedade. Rio de Janeiro: FIOCRUZ/CCBB; 1996. p. 235-249.

Hasenbalg C e Silva NV. Notas sobre a desigualdade racial e política no Brasil. Estudos Afro-Asiáticos 1993; 25: 141-159.

Heilborn ML e Gouveia PF. "Marido é tudo igual": mulheres populares e sexualidade no contexto da aids. In: Barbosa R. e Parker R, orgs. Sexualidades pelo avesso: direitos, identidades e poder. Rio de Janeiro: IMS/UERJ; São Paulo: Editora 34; 1999. p. 175198.

Heringer R. Faces e cores da desigualdade no Brasil: um balanço dos anos 90. Democracia Viva 2001 jul-ago; 11: 42-46.

Herman AA. Toward a conceptualization of race in epidemiologic research. Ethnicity and Disease 1996; 6: 7-20.

Hita MG. Mãe-Vó-Bi: chefe de família em arranjo matrifocal negro. Encontro Nacional de Estudos Populacionais [CDRom] 2002 nov 4-8; Minas Gerais, Brasil. Ouro Preto: ABEP, 2002.

Hulley SB, Cummings SR. Diseño de la investigación clínica. Barcelona: Doyma Ediciones, 1993.

[IBGE] Instituto Brasileiro de Geografia e Estatística. Indicadores Sociais Mínimos. Censo $2000 . \quad$ Disponível em URL: $<$ http://www.ibge.gov.br/ibge/estatistica/populacao/condicaodevida/indicadoresminimos $>$ [2001 Jan 24].

Iglesias MDP, Gonçalves MDPI, Melo JCC, Lopes EZ, Moreira MA. Acolhimento e adesão ao tratamento dos usuários do SAE-PG. In: Anais do I Fórum e II Conferência de Cooperação Técnica Horizontal da América Latina e do Caribe em HIV/AIDS e DST 2000 nov 6-10; v. 2, Rio de Janeiro, Brasil. Brasília: Ministério da Saúde, Secretaria de Políticas de Saúde, Coordenação Nacional de DST/AIDS; 2000. p. 1.023.

[INSPIR] Instituto Sindical Interamericano pela Igualdade Racial. Mapa da população negra no mercado de trabalho: regiões metropolitanas de São Paulo, Salvador, Recife, Belo Horizonte, Porto Alegre e Distrito Federal. São Paulo: AFL-CIO; 1999.

[IPEA] Instituto de Pesquisas Econômicas Aplicadas. O perfil da discriminação no mercado de trabalho: um recorte de raça e gênero. Disponível em <URL: http://www.ipea.gov.br/pub> [2001 Ago 28]

Januzzi PM. Indicadores sociais no Brasil. Campinas: Alínea, 2001.

Jesus JS. Aconselhamento pré e pós-teste: fator de contribuição para a qualidade de vida do soropositivo. In: Anais do I Fórum e II Conferência de Cooperação Técnica Horizontal da América Latina e do Caribe em HIV/AIDS e DST 2000 nov 6-10; v. 2, Rio de Janeiro, Brasil. Brasília: Ministério da Saúde, Secretaria de Políticas de Saúde, Coordenação Nacional de DST/AIDS; 2000. p. 587.

Jones DR, Harrell JP Morris-Prather CE, Thomas J, Omowale N. Affective and physiological responses to racism: the roles of afrocentrism and mode of presentation. Ethnicity and Disease 1996; 6: 109-122.

Kass G. An exploratory technique for investigating large quantities of categorical data. Applied Statistics 1980; 29(2): 119-127. 
Knauth DR. Subjetividade e políticas de identidade no Brasil. In: Barbosa R e Parker R, orgs. Sexualidades pelo avesso: direitos, identidades e poder. Rio de Janeiro: IMS/UERJ; São Paulo: Editora 34; 1999. p. 121-136.

Krieger J, Higgins D. Housing and health: time again for public health action. American Journal of Public Health 2002; 92(5): 758-768.

Krieger N. Does racism harm health? Did child abuse exist before 1962? On explicit questions, critical science, and current controversies: an ecosocial perspective. American Journal of Public Health 2003; 93(2): 194-199.

Krieger N, Sidney S, Coakley E. Racial discrimination and skin color in the CARDIA study: implications for Public Health Research. American Journal of Public Health 1998; 88(9): 1.308-1.313.

Krieger N, Rowley DL, Herman AA, Avery B, Phillips MT. Racism, sexism and social class: implications for studies of health, disease and well-being. American Journal of Preventive Medicine 1993; 9(Suppl. 2): 82-122.

Lam D. The impact of race on earnings and human capital in Brazil, South Africa and the United States. Encontro Nacional de Estudos Populacionais [CDRom] 2002 nov 4-8; Minas Gerais, Brasil. Ouro Preto: ABEP, 2002.

La Veist TA. Why we should continue to study race... but do a better job: an essay on race, racism and health. Ethnicity and Disease 1996; 6: 21-29.

Leite JCC, Drchler ML, Silveira V, Pinheiros CAT. Adesão aos anti-retrovirais: influência das atitudes dos pacientes em relação ao tratamento. In: Anais do I Fórum e II Conferência de Cooperação Técnica Horizontal da América Latina e do Caribe em HIV/AIDS e DST 2000 nov 6-10; v. 2, Rio de Janeiro, Brasil. Brasília: Ministério da Saúde, Secretaria de Políticas de Saúde, Coordenação Nacional de DST/AIDS; 2000. p. 1.008 .

Lemos KRV e Valente JG. A declaração de óbito como indicador de sub-registro de casos de AIDS. Cadernos de Saúde Pública 2001; 17(3).

Lignani Júnior L, Greco DB, Carneiro M. Avaliação da aderência aos anti-retrovirais em pacientes com infecção pelo HIV/AIDS. Cadernos de Saúde de Pública 2001; 35(6).

Lima LCA, Berquó E, Lopes F, Oliveira KA, Pinho MD, Pereira N. Estudo dos diferenciais raciais/étnicos no uso de drogas. Encontro Nacional de Estudos Populacionais [CDRom] 2002 nov 4-8; Minas Gerais, Brasil. Ouro Preto: ABEP, 2002.

Lopes AA. Significado de raça em pesquisas médicas e epidemiológicas. In: Barata RB et al., orgs. Equidade e Saúde: contribuições da epidemiologia. Série EpidemioLógica, n. 1. Rio de Janeiro: FIOCRUZ/ABRASCO; 1997. p. 245-257.

Lopes F, Berquó E, Pereira N, Pinho, MD, Oliveira KA, Lima LCA. Auto-atribuição de risco de infecção por HIV na população brasileira: um estudo com recorte racial. In: Berquó $\mathrm{E}$ et al. A População Negra Brasileira frente ao HIV/AIDS: Uma Proposta de Treinamento em Pesquisa para Pesquisadores Negros. [Relatório Final apresentado à Fundação MacArthur]. São Paulo: CEBRAP; 2002. (mimeo)

Lopes F, Buchalla CM, ECI Brazilian Team. Em busca da equidade: o quesito raça/cor nas estatísticas de aids. Rev Brasileira de Epidemiologia 2002 mar; 217 (Supl. Especial).

Lopes, F e Buchalla, CM. Situações de não efetivação de direitos humanos de mulheres negras e não negras que convivem com HIV/AIDS. In: Anais do VII Congresso Paulista de Saúde Pública e Democracia 2001; São Paulo: Associação Paulista de Saúde Pública; 2001. p. 180. 
Lopes F e Malachias R. Assumir a diferença para promover a igualdade: a importância do quesito cor na investigação epidemiológica. Boletim Epidemiológico de AIDS do PEDST/AIDS Secretaria do Estado da Saúde. São Paulo 2001 out; Ano XIX(2): 3-5. Disponível em <URL: http//:www.jbaids.com.br>

López IFH. Race and erasure: the salience of race to Latinos/as. In: Delgado R e Stefanic J, eds. Critical race theory: the cutting edge. 2. ed. Philadelphia: Temple University Press; 2000. p. 369-378.

The social construct of race. In: Delgado R e Stefanic J, eds. Critical race theory: the cutting edge. 2 . ed. Philadelphia: Temple University Press; 2000. p 163-175.

Luppi CG. A infecção pelo vírus da imunodeficiência humana em mulheres atendidas em centro de testagem e aconselhamento: um estudo caso-controle. São Paulo; 2002. [Tese de Doutorado - Faculdade de Medicina da Universidade de São Paulo]

Maggie Y. "Aqueles a quem foi negada a cor do dia": as categorias cor e raça na cultura brasileira. In: Maio MC e Santos RV, orgs. Raça, Ciência e Sociedade. Rio de Janeiro: FIOCRUZ/CCBB; 1996. p. 225-234.

Mann JM e Tarantola DJM. Vulnerability: personal and programmatic. In: , eds. The Global Aids Policy Coalition. Aids in the world II. New York: Oxford University Press; 1996. p. 441-463.

Mann J, Tarantola DJM, Netter TW. A Aids no Mundo. Rio de Janeiro: ABIA/IMS/Relume-Dumará, 1993.

Mann JM. Health and human rights. In: Mann JM, Gruskin S, Grodin MA, Annas JG, orgs. Health and human rights: a reader. New York: Routledge; 1999. p. 216-226.

A Aids no Mundo. Rio de Janeiro: Relume-Dumará/ABIA/IMS/UERJ; 1993.

Mann JM, Gruskin S, Grodin MA e Annas GJ. Health and human rights. In: Health and human rights: a reader. New York: Routledge; 1999. p. 7-20.

Marques HHS, Latorre MRDO, DellaNegra M, Pluciennik AMA, Salomão MLM e Grupo de Pesquisadores do Enhancing Care Initiative. Falhas na identificação da infecção pelo HIV durante a gravidez em São Paulo, SP, 1998. Rev. Saúde Pública 2002 ago; 36(4).

Martins AL e Tanaka ACD. Mulheres negras e mortalidade no Estado do Paraná, Brasil, de 1993 a 1998. Rev Brasileira Crescimento e Desenvolvimento Humano 2000; 10(1): 27-38.

Martins AL. Mortalidade materna: maior risco para mulheres negras no Brasil. Jornal da RedeSaúde 2001 mar 23; p. 37-40.

Martins RB. Desigualdades raciais no Brasil. Disponível em <URL: http://www.ipea.gov.Br/pub/Desigualdades_raciais.ppt> [2001, Dez. 15]

Mendes MA. Mulheres chefes de família: a complexidade e a ambigüidade da questão. Encontro Nacional de Estudos Populacionais [CDRom] 2002 nov 4-8; Minas Gerais, Brasil. Ouro Preto: ABEP, 2002.

Mensch B. Quality of care: a neglected dimension. In: Koblinsky M et al., eds. The health of women: a global perspective. United States of America:Westview Press; 1993. p. 235-254.

Mesquita F. Dar oportunidade de vida ao usuário de drogas injetáveis, polêmica nacional. Disponível em <URL: http:www.aids.gov.br/drogas/seringas/doc06.htm> [16/4/2003] 
Mesquita F e Seibel S, orgs. Consumo de drogas: desafios e perspectivas. Série Saúde Loucura (textos 14). São Paulo: Hucitec; 2000.

Minayo MCS. Souza ER, Assis SG, Cruz Neto O, Deslandes SF, Silva CMFP. Avaliação de Orientação e Apoio Sorológico/CTA/COAS da região Nordeste do Brasil. Cadernos de Saúde Pública 1999; 15(2): 355-367.

Minkoff $\mathrm{H}$, de Hovitz JA, Duerr A. HIV infection in women. New York: Raven Press; 1995.

Miranzi, MAS e Miranzi SSC. Ulcerações orais em pacientes infectados por HIV. In: Anais do I Fórum e II Conferência de Cooperação Técnica Horizontal da América Latina e do Caribe em HIV/AIDS e DST 2000 nov 6-10; v. 2, Rio de Janeiro, Brasil. Brasília: Ministério da Saúde, Secretaria de Políticas de Saúde, Coordenação Nacional de DST/AIDS; 2000. p. 662.

Mota MP. Gênero e sexualidade: fragmentos de identidade masculina nos tempos de aids. Cadernos de Saúde Pública 1998; 14(1).

[MS] Ministério da Saúde. Pessoas que vivem com HIV/AIDS: direitos. Brasília: MS; 1996.

[MS] Ministério da Saúde. Boletim Epidemiológico AIDS, dez. 1997 a fev. 1998. Brasília: MS; 1998.

[MS] Ministério da Saúde. Boletim Epidemiológico AIDS, Ano XIII, n. 1, dez 1999 a jun 2000. Brasília: MS; 2000.

[MS] Ministério da Saúde. Boletim Epidemiológico AIDS, Ano XV, n. 1, jul a set 2001. Brasília: MS; 2001.

[MS] Ministério da Saúde. Boletim Epidemiológico AIDS, Ano XV, n. 1, out 2001 a mar 2002. Brasília: MS; 2002a.

[MS] Ministério da Saúde. Secretaria de Programas de Saúde. Coordenação Nacional de DST/AIDS. Unidade de Prevenção. Políticas e diretrizes de prevenção e assistência das DST/AIDS entre mulheres. Brasília: MS; 2002b. (mimeo)

[MS/CEBRAP] Ministério da Saúde. Centro Brasileiro de Análise e Planejamento. Comportamento Sexual da População Brasileira e Percepções do HIV/AIDS. Série Avaliação, n. 4. Brasília: MS; 2000.

Munanga K. Mestiçagem e identidade afro-brasileira. In: Oliveira I, org. Relações raciais e educação: alguns determinantes. Cadernos PENESB, n. 1. Rio de Janeiro: Intertexto; 1999. p. 9-20.

. Estratégias e políticas de combate à discriminação racial. São Paulo: Edusp/Estação Ciência; 1996.

. Negritude: usos e sentidos. São Paulo: Ática, 1986. 54.

Racismo: da desigualdade à intolerância. São Paulo em Perspectiva 1990; 4(2):51-

Muntaner C, Nieto FJ, O'Campo P. The Bell curve: on race, social class, and epidemiologic research. American Journal of Epidemiology 1996; 144(6): p.531-536.

Murray LR. Sick and tired of being sick and tired: scientific evidence, methods, and research implications for racial ant ethnic disparities in occupational health. American Journal of Public Health 2003; 93(2): 221-226. 
Nogueira O. Norberto Bobbio: o semeador de idéias. Correio do Livro da Universidade de Brasília $2001 \mathrm{mar} / \mathrm{maio}$; 2: 26-34.

Olinto MTA e Olinto BA. Raça e desigualdade entre as mulheres: um exemplo no sul do Brasil [nota]. Cadernos de Saúde Pública 2000; 16(4).

Oliveira F. Atenção adequada à saúde e ética na ciência: ferramentas de combate ao racismo. Perspectivas em saúde e direitos reprodutivos 2001 maio; Ano 2, 4: 24-29.

O recorte racial/étnico e a saúde reprodutiva: mulheres negras. In: Giffin K, org. Questões da saúde reprodutiva. Rio de Janeiro: FIOCRUZ; 1999. p. 419-438.

Oliveira LA. Comparação de dois indicadores da desnutrição materna usando regressão e classificação por árvore e logística multinomial. São Paulo; 1996. [Tese de Doutorado - Faculdade de Saúde Pública da Universidade de São Paulo]

[OPAS] Organização Panamericana de Saúde. El VIH y el sida en las Américas: una epidemia con muchas caras [temas de actualidad]. Rev Panamericana de Salud Publica; 2002.

[OPAS] Organização Panamericana de Saúde. Joint United Nations Programme on HIV/AIDS. Research plan to reduce health disparities in the United States of America [temas de actualidad]. Rev Panamericana de Salud Publica; 2001.

Paiva V. Sem mágicas soluções: a prevenção ao HIV e à Aids como um processo de emancipação psicossocial. In: Parker R, Terto Júnior, V, orgs. Aprimorando o debate: respostas sociais frente à AIDS: limites e possibilidades na terceira década. Rio de Janeiro: ABIA; 2002. p. 20-27.

Cenas sexuais, roteiros de gênero e sujeito sexual. In: Barbosa R e Parker R, orgs. Sexualidades pelo avesso: direitos, identidades e poder. Rio de Janeiro: IMS/UERJ; São Paulo: Editora 34; 1999. p. 249-269.

Fazendo arte com a camisinha: sexualidades jovens em tempos de aids. São Paulo: Summus; 2000.

. O simbolismo da aids, alteridade e cidadania. In: viva a vida. São Paulo: Summus; 1992. p. 53-62.

Risk perception and counselling among HIV-positive women in Sao Paulo, Brazil. International Journal of STD/AIDS 2000; 11: 112-114.

Paiva V, Bugamelli L, Leme B, Ventura-Filipe E, Tunala L, Santos NJS. SIDA, vulnerabilidad y condicionantes de genero. Cuadernos Mujer Salud 1998; 3: 34-38.

. Sexualidade de mulheres vivendo com HIV/AIDS em São Paulo. Cadernos de Saúde Pública 2002; 18(6).

. Lidando com a adesão: a experiência de profissionais e ativistas na cidade de São Paulo. In: Teixeira PR et al., orgs. Ta difícil de engolir? Experiências de adesão ao tratamento anti-retroviral em São Paulo. São Paulo: Nepaids; 2000. p. 28-78.

Paixão M. Brasil: retrato em branco e preto. Democracia Viva 2002 mar-jun; 13: 84-87.

Panos Institute. Associação Brasileira Interdisciplinar de Aids. SOS CORPO - Gênero e Cidadania. A tripla ameaça: mulheres e aids. Rio de Janeiro: ABIA; 1993.

Parker R Corpos, prazeres e paixões: a cultura sexual no Brasil contemporâneo. São Paulo: Bestseller; 1991.

A construção da solidariedade: aids, sexualidade e política no Brasil. Rio de Janeiro: ABIA/IMS,UERJ/Relume-Dumará; 1994. 
Parker R e Camargo Júnior, KR. Pobreza e HIV/AIDS: aspectos antropológicos e sociológicos. Cadernos de Saúde Pública 2000; 16(1 Supl.): 89-102.

Parker R e Galvão J Introdução. In: ___ orgs. Quebrando o silêncio: mulheres e aids no Brasil. Série História Social da AIDS, n. 7. Rio de Janeiro: RelumeDumará/ABIA/IMS/UERJ, 1996. p. 7-16.

Parker R e Aggleton P. Estigma, discriminação e aids. Coleção ABIA - Cidadania e Direitos, n. 1. Rio de Janeiro: ABIA; 2001.

Paxton K, Myers H, Wyatt G. Do the factors that predict sexual risk behavior among women differ by ethnicity? XIV International Conference Aids [CDRom] 2002 jul 7-12; Barcelona, Espanha. Bologna: Monduzzi Ed.; 2002. p. 163-166.

[PE-DST/AIDS] Programa Estadual de DST/AIDS da Secretaria do Estado da Saúde - São Paulo. Boletim Epidemiológico de AIDS. Ano XIX, n. 2; 2001.

Perea JF. The black/white binary paradigm of race. In: Delgado R, Stefanic J, eds. Critical race theory: the cutting edge. 2. ed. Philadelphia: Temple University Press, 2000. p. 344-353.

Perpétuo IHO. Raça e acesso às ações prioritárias na agenda de saúde reprodutiva. Jornal da RedeSaúde 2000; 22: 10-16.

Petruccelli JL. A cor denominada: Estudo das informações do suplemento da PME, julho/98. Rio de Janeiro: IBGE; 2000.

A declaração de cor/raça no Censo 2000: um estudo comparativo. Textos para Discussão, Diretoria de Pesquisas do Departamento de População e Indicadores Sociais, n. 6. Rio de Janeiro: IBGE; 2002.

. Seletividade por cor e escolhas conjugais no Brasil dos 90. Estudos Afro-Asiáticos 2001; Ano 23, 1: 29-52.

Petry S. Até na hora do parto negra é discriminada. Folha de S. Paulo On Line, Cotidiano, 2002 maio 26.

Pinho MD. Vulnerabilidade da população negra ao HIV/AIDS. População Negra em Destaque. São Paulo: CEBRAP; 1998. p.56-58.

Pinho MD, Berquó E, Lopes F, Oliveira KA, Lima LCA, Pereira N. Juventudes, raça e vulnerabilidades. Encontro Nacional de Estudos Populacionais [CDRom] 2002 nov 48; Minas Gerais, Brasil. Ouro Preto: ABEP, 2002.

Pinto E e Souzas R. A mortalidade materna e a questão raça/etnia: importância da lei do quesito cor no sistema de saúde. Perspectivas em saúde e direitos reprodutivos 2002 maio; Ano 3, 5: 28-30.

Pinto EA, Boulos SR e Assis M. A saúde mental da população negra: uma breve reflexão a partir da experiência com grupos de auto-ajuda. In: Werneck J et al., orgs. O livro da saúde das mulheres negras: nossos passos vêm de longe. Rio de Janeiro: Pallas; 2000. p. 171-178.

Pinto RP. Classifying the Brazilian population by color: underlying problems. Brazilian issues on education, gender and race. São Paulo: Fundação Carlos Chagas; 1996. p. 189-213.

Polejack L. Casais com sorologias diferentes para HIV/AIDS: uma realidade em construção. In: Anais do I Fórum e II Conferência de Cooperação Técnica Horizontal da América Latina e do Caribe em HIV/AIDS e DST 2000 nov 6-10; v. 2, Rio de Janeiro, 
Brasil. Brasília: Ministério da Saúde, Secretaria de Políticas de Saúde, Coordenação Nacional de DST/AIDS; 2000. p. 1.017.

[PROAIM] Programa de Aprimoramento das Informações de Mortalidade no Município de São Paulo. Variável raça/cor e a mortalidade no município de São Paulo 2001; 41 (dados referentes ao $3^{\circ}$ trim. 2000).

Rahier J. "Mãe, o que será que o negro quer?" Representações racistas na Revista Vistazo, 1957-1991. Estudos Afro-Asiáticos 2001; Ano 23, 1: 5-28.

Ribeiro FR. Ideologia nacional, antropologia e "questão racial". Estudos Afro-Asiáticos 1997; 31: 79-89.

Ricoeur P. Interpretação e ideologias. Rio de Janeiro: Francisco Alves; 1988. p. 67-76; 119-130.

Rodrigues LM. Exemplos de vida positiva. Boletim Arayê/ABIA 1997; Ano 2, 7.

Roland E. Mulher Negra e Aids. Rio de Janeiro; 1992. (mimeo)

Rosemberg F e Pinto RP. Saneamento básico e raça. Rev Brasileira de Crescimento e Desenvolvimento Humano 1995; 5 (1 e 2): 23-38.

Roso A. Ideologia e relações de gênero: um estudo de recepção das propagandas de prevenção da AIDS. Cadernos de Saúde Pública 2000; 16(2).

Rossato C e Gesser V. A experiência da branquitude diante de conflitos raciais: estudos de realidades brasileiras e estadunidenses. In: Cavalleiro E, org. Racismo e anti-racismo na educação: repensando nossa escola. São Paulo: Summus; 2001.

Rufino A. Pancada de amor dói. E muito. In: Werneck $J$ et al. O livro da saúde das mulheres negras: nossos passos vêm de longe. Rio de Janeiro: Pallas, 2000. p.143-146.

Sant'Anna W. Desigualdades étnico/raciais e de gênero no Brasil: as revelações possíveis do IDH e do IDG. Jornal da RedeSaúde 2001a mar 23; p. 16-19.

- Relações raciais no Brasil: entre a unanimidade e a paralisia [documento]. Perspectivas em saúde e direitos reprodutivos 2001b; Ano 2, 4: 53-68.

Santo AH, Pinheiro CE, Jordani MS. Causas básicas e associadas de morte por Aids, Estado de São Paulo, Brasil, 1998. Rev de Saúde Pública 2000; 34(6).

Santos BS. A construção multicultural da igualdade e da diferença. VII Congresso Brasileiro de Sociologia 1995 set 4-6; Rio de Janeiro, Brasil; 1995. (mimeo)

Por uma concepção multicultural de direitos humanos. In: Feldman BB e Capinha G, org. Identidades: estudos de cultura e poder. São Paulo: Hucitec; 2000. p.19-39.

Santos CP, Nascimento VLV. Felipe YX. Aderência ao tratamento anti-retroviral: resultados preliminares e reflexões da experiência em um serviço universitário - Casa da Aids. In: Teixeira PR et al., orgs. Ta difícil de engolir? Experiências de adesão ao tratamento anti-retroviral em São Paulo. São Paulo: Nepaids; 2000. p. 122-128.

Santos EM. Aids e mulher: desafios para definições de políticas de intervenção. In: Parker R e Galvão J, orgs. Quebrando o silêncio: mulheres e aids no Brasil. Série História Social da AIDS, n. 7. Rio de Janeiro: Relume-Dumará/ABIA/IMS/UERJ, 1996. p. 79-88.

Santos M. O espaço do cidadão. 2. ed. São Paulo: Nobel; 1992.

Por uma outra globalização: do pensamento único à consciência universal. 4. ed. Rio de Janeiro: Record; 2000. 
Santos NJS. A AIDS entre as mulheres no estado de São Paulo. In: Parker R e Galvão J, orgs. Quebrando o silêncio: mulheres e aids no Brasil. Série História Social da AIDS, n. 7. Rio de Janeiro: Relume-Dumará/ABIA/IMS/UERJ, 1996. p. 33-60.

As mulheres e a aids. São Paulo; 1994. [Dissertação de Mestrado - Faculdade de Saúde Pública da Universidade de São Paulo]

. As mulheres e suas decisões reprodutivas, diante da epidemia de HIV/AIDS. São Paulo; 2002. [Tese de Doutorado - Faculdade de Saúde Pública da Universidade de São Paulo]

Santos NJS e Munhoz R. A Aids entre as mulheres: reflexões sobre seus depoimentos. In: Parker R e Galvão J, orgs. Quebrando o silêncio: mulheres e aids no Brasil. Série História Social da AIDS, n. 7. Rio de Janeiro: Relume-Dumará: ABIA/IMS/UERJ, 1996. p. 115-136.

Santos NJS, Buchalla CM, Ventura EF, Bugamelli L, Garcia S, Paiva V. Mulheres HIV positivas, reprodução e sexualidade. Rev de Saúde Pública 2002; 36(4 Supl.): 12-23.

HIV positive women, reproduction and sexuality in Sao Paulo, Brazil. Reproductive Health Matters 1998; 6(12): 31-41.

Santos RV. Da morfologia às moléculas, de raça à população: trajetórias conceituais em antropologia física no século XX. In: Maio MC e Santos RV, orgs. Raça, Ciência e Sociedade. Rio de Janeiro: FIOCRUZ/CCBB; 1996. p. 125-142.

Scott JW. Gênero: uma categoria útil para a análise histórica. 2. ed. Recife: SOS CORPO - Gênero e Cidadania; 1995. p. 1-19.

Sen A. Desenvolvimento como liberdade. São Paulo: Companhia das Letras, 2000.

[SES] Secretaria de Estado da Saúde. São Paulo. Boletim Epidemiológico de Aids do PEDST/AIDS 2001 out.; 2.

Silva CGM. O significado da fidelidade e as estratégias para prevenção da aids entre homens casados. Rev de Saúde Pública 2002; 36(4 Supl.): 40-49.

Silva JAN, Oliveira VF, Queiroz VAS. Etnia e miomatose em João Pessoa. João Pessoa; 2002. (mimeo)

Silva JM e Guimarães MAC. Odo-Ya project: HIV/AIDS prevention in the context of AfroBrazilian religion. Journal of Health Community 2000; 5(Suppl.. 1): 119-122.

Silva Júnior H. Mulher e negra: a necessidade de demandas judiciais específicas. In: Barsted LL et al., eds. As mulheres e a legislação sobre o racismo. Rio de Janeiro: CEPIA, 2001. p. 9-42.

Silva NV. Uma nota sobre "raça social" no Brasil. Estudos Afro-Asiáticos 1994; 26: 67-80.

Soares S. Discriminação de gênero e raça no mercado de trabalho. Mercado de trabalho: conjuntura e análise [edição especial para a Conferência Nacional contra o Racismo e a Intolerância]. IPEA: Rio de Janeiro, Ano 6, n. 13; 2001 jun. p. 39-45.

Souza VC. Miomatose em negras e brancas brasileiras: semelhanças e diferenças. Jornal da RedeSaúde 2001 mar 23; p. 20-23.

Prevalência de miomas uterinos em mulheres negras: as dificuldades e avanços na coleta e análise de dados com recorte racial. In: Werneck $J$ et al., orgs. O livro da saúde das mulheres negras: nossos passos vêm de longe. Rio de Janeiro: Pallas, 2000. p. 8894. 
Prevalência de miomas uterinos em mulheres negras: um estudo de caso. População

Negra em Destaque. São Paulo: CEBRAP; 1998. p. 49-51.

Szwarcwald CL, Bastos FI, Esteves MAP, Andrade CLT. A disseminação da epidemia da aids no Brasil, no período de 1987-1996: uma análise espacial. Cadernos de Saúde Pública 2000; 16(1): 7-19.

Szwarcwald CL e Castilho EA. Estimativa do número de pessoas de 15 a 49 anos infectadas pelo HIV, Brasil, 1998. Cadernos de Saúde Pública 2000; 16(1): 135-141.

Telles EE. Industrialização e desigualdade racial no emprego: o exemplo brasileiro. Estudos Afro-Asiáticos 1994; 26: 21-51.

Teodoro H. Algumas considerações sobre a mulher negra. In: Neves ATC, org. Identidade negra e religião: consulta sobre cultura negra e teologia na América Latina. São Paulo: CEDI/Edições Liberdade; 1986. p. 177-183.

Ter Meulen J, Eberhardt HC, Luande J, Mgaya HN, Chang-Claude J, Mitiro H et al. Human papillomavirus (HPV) infection, HIV infection and cervical cancer in Tanzania, East Africa. International Journal of Cancer 1992; 51:515-21.

Tunala L. Fontes cotidianas de estresse entre mulheres portadoras de HIV. Rev de Saúde Pública 2002; 36 (4 Supl.): 24-31.

Tunala L, Paiva V, Ventura Filipe E, Santos TLL, Santos NJS, Hearst. Fatores psicossociais que dificultam a adesão das mulheres portadoras do HIV aos cuidados de saúde. In: Teixeira PR et al., org. Ta difícil de engolir? Experiências de adesão ao tratamento anti-retroviral em São Paulo. São Paulo: Nepaids; 2000. p. 83-114.

[UNAIDS] Joint United Nations Programme on HIV/AIDS. Aids epidemic update. Geneva: UNAIDS; 2000 Dec.

[UNAIDS] Joint United Nations Programme on HIV/AIDS. Aids epidemic update. Geneva: UNAIDS; 2002b Dec.

[UNAIDS] Joint United Nations Programme on HIV/AIDS. Report on the global HIV/AIDS epidemic. Geneva: UNAIDS; 2002a July.

[UNAIDS] Joint United Nations Programme on HIV/AIDS. World Health Organization. Global HIV/AIDS \& STD surveillance. Disponível em URL:

$<$ http://www.who.int/emc-hiv/global_report/rep_html/report3.html $>$ [1998 Out 15]

Valongueiro S e Campineiro D. Demand for health care in Brazil: a preliminary analysis by regions. Encontro Nacional de Estudos Populacionais [CDRom] 2002 nov 4-8; Minas Gerais, Brasil. Ouro Preto: ABEP, 2002.

Van Ryn M e Fu SS. Paved with good intentions: do public health and human service providers contribute to racial/ethnic disparities in health? American Journal of Public Health 2003; 93(2): 248-255.

Vermelho LL, Barbosa RHS e Nogueira AS. Mulheres com aids: desvendando histórias de risco. Cadernos de Saúde Pública 1999; 15(2): 369-379.

Vermeulen H. Essencializando a diferença: o censo demográfico, o multiculturalismo e os multirraciais nos Estados Unidos. Estudos Afro-Asiáticos 2000; 37: 7-28.

Vernon SD, Reeves WC, Clancy KA, Laga M, St Louis M, Gary HE et al. A longitudinal study on human papillomavirus DNA detection in human immunodeficiency virus type 1seropositive and seronegative women. Journal of Infections Diseases 1994 May; 169:1.108-1112. 
Vieira EM, Villela WV, Réa MF, Fernandes MEL, Franco E, Ribeiro G. Alguns aspectos do comportamento sexual e prática de sexo seguro em homens do município de São Paulo. Cadernos de Saúde Pública 2000; 16(4).

Villela WV. Prevenção do HIV/AIDS, genro e sexualidade: um desafio para os serviços de saúde. In: Barbosa $\mathrm{R}$ e Parker R, orgs. Sexualidades pelo avesso: direitos, identidades e poder. Rio de Janeiro: IMS/UERJ; São Paulo: Editora 34; 1999. p. 199-214.

. Refletindo sobre a negociação sexual como estratégia de prevenção da aids entre as mulheres. In: Parker R e Galvão, J, orgs. Quebrando o silêncio: mulheres e aids no Brasil. Série História Social da AIDS, n. 7. Rio de Janeiro: RelumeDumará/ABIA/IMS/UERJ; 1996. p. 181-190.

Homens que fazem sexo com mulheres. São Paulo: NEPAIDS; 1997.

Waldvogel BC. e Morais LCC. Mudanças no padrão da mortalidade por aids no estado de São Paulo. Encontro Nacional de Estudos Populacionais [CDRom] 2002 nov 4-8; Ouro Preto, Minas Gerais. Minas Gerais: ABEP; 2002a.

O cenário promissor da evolução da mortalidade por aids no Estado de São Paulo no final do século XX. Boletim Epidemiológico AIDS. Mortalidade nas regionais do estado de São Paulo, Ano XXI, n. 1. São Paulo: Programa Estadual de DST/AIDS; 2002b. p. 3-7.

Wasserheit JN. Epidemiological synergy: interrelationships between human immunodeficiency virus infection an other sexually transmitted diseases. Sexually Transmitted Diseases 1992 March-April. p. 61-77.

Werneck J. Aids: a vulnerabilidade das mulheres negras. Jornal da RedeSaúde 2001 mar 23; p. 31-33.

. O desafio das ialodês: mulheres negras e a epidemia de HIV/AIDS. In: Werneck J et al., orgs. O livro da saúde das mulheres negras: nossos passos vêm de longe. Rio de Janeiro: Pallas, 2000. p. 95-102.

White E. O amor não justifica: mulheres negras e violência doméstica. In: Werneck J et al., orgs. O livro da saúde das mulheres negras: nossos passos vêm de longe. Rio de Janeiro: Pallas, 2000. p. 147-152.

Williams DR. The monitoring of racial/ethnic status in the USA: data quality issues. Ethnicity and Health 1999; 4(3): 121-137.

Williams DR, Neighbors HW, Jackson J. Racial/Ethnic Discrimination and health: findings from community studies. American Journal of Public Health 2003; 93(2): p. 200-208.

Wilson AO e Adamchak DJ. The grandmothers' disease - the impact of Aids on Africa's older women [Commentary]. Age and Ageing 2001; 30: p. 8-10.

Wood CH. e Carvalho JAM. Categorias do censo e classificação subjetiva de cor no Brasil. Rev Brasileira de Estudos Populacionais 1994; 11(1): 3-15.

Zampieri CP, Santos IM, Lopes EZ, Moreira MA. Prevalência de lesões orais em pacientes atendidos no serviço de assistência especializada de Praia Grande - SP. In: Anais do I Fórum e II Conferência de Cooperação Técnica Horizontal da América Latina e do Caribe em HIV/AIDS e DST 2000 nov 6-10; v. 2, Rio de Janeiro, Brasil. Brasília: Ministério da Saúde, Secretaria de Políticas de Saúde, Coordenação Nacional de DST/AIDS; 2000. p. 988. 
ANEXOS 


\title{
ANEXO I
}

\author{
HOSPITAL DAS CLINICAS

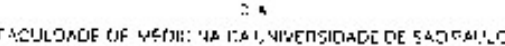

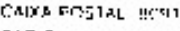

DIRETORIA CLINICA

\section{Comissāo de Éicica para Análise de Projetos de Pesquisa}

A Comissão de Ética para Anàlise de Projetos de Pesquisa - CAPPesq da Diretoria Clinica do Hospital das Clinicas e da Faculdade de Medicina da Universidade de São Paulo, em sessāo de 09.12.98, ANALISOU E APRovou o Protocolo de Pesquisa $n^{\circ}$ 670/98, intitulado: "Vutnerabifidiade e o cuidado às pessoas vivendo com HIV-AIDS: Um estudo sobre a assistencia às mutheres vivendo com HIV-AIDS nos serviços públicos de saúde das cidades de Santos e Săo Pauto- Brasil", apresentado peto(a) pesquisador(a) Dr. José Ricardo de Carvatho Mesquita Ayres, do Departamento de Medicina Preventiva, bem como o Termo de Consentimento Pós-Informaçăo.

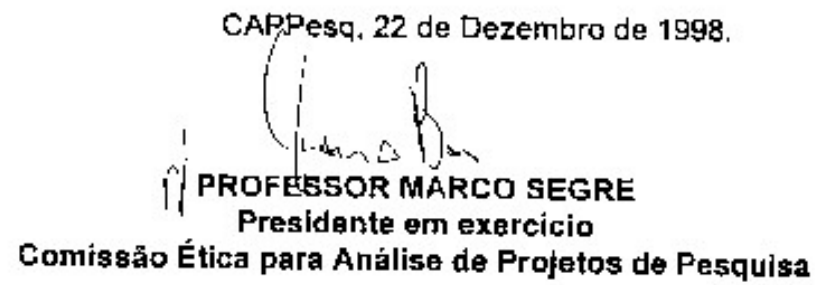

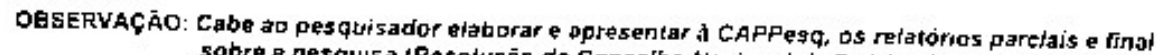

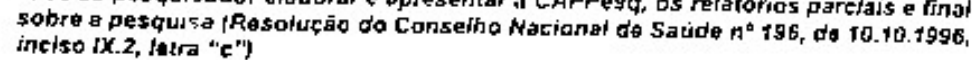


ANEXO II

HOSPITAL DAS CLINICAS

FAC:JLLADE DE MEDICINA DA UNIVERSICAOE DE SAO DAULLC:

TERMO DE CONSENTIMENTO POS INFORMAÇĀO

finqusceses parg preenchumento no versol

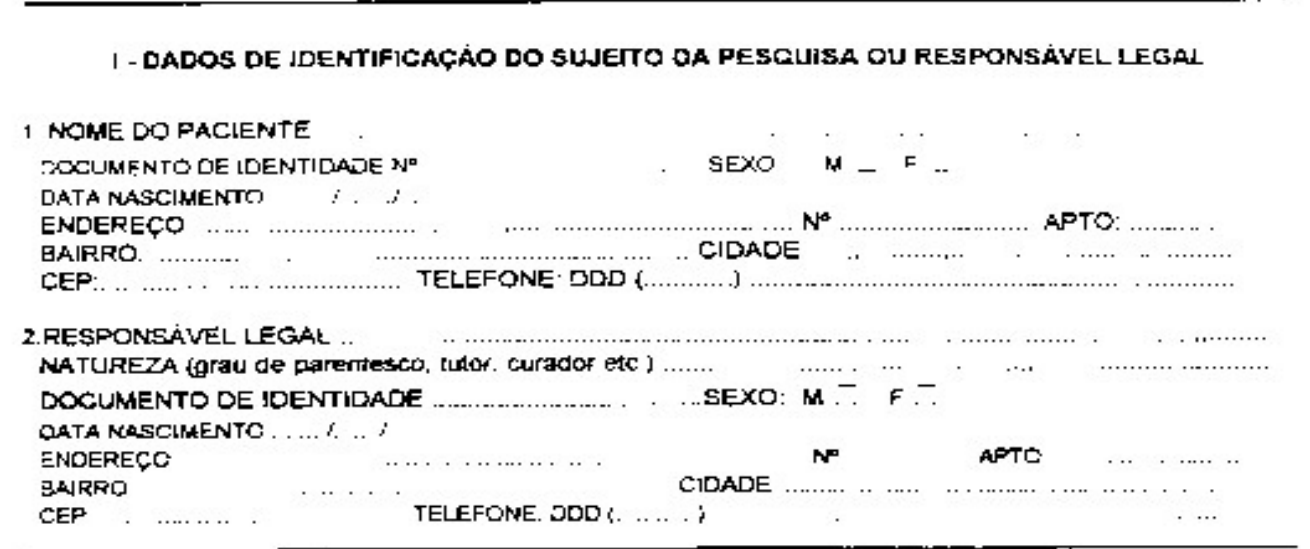

\section{II - DADOS SOBRE A PESOUISA GIENTIFICA}

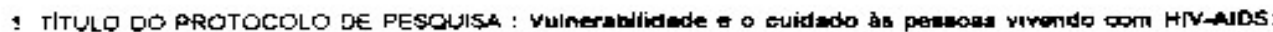

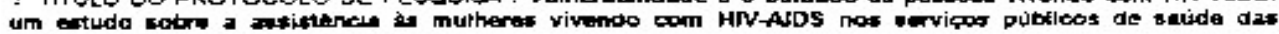

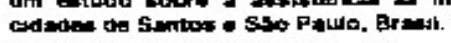

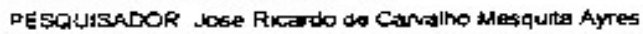

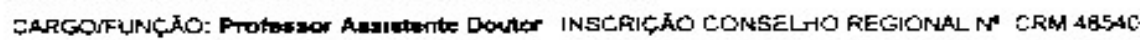
JNIQADE ఇO HCFMUSP: Departanento de Medrono Prowenting - FMUSP

3 AVAUACAO DO RISCO DA PESOUISA

$\begin{array}{lllll}\text { SEM RISCO } & \text { RISCOMINIMO } & \mathbf{2} & \text { FISCO KEOIO } \\ \text { RISCO EAIXC - } & \text { RISCOMAIOR } & -\end{array}$

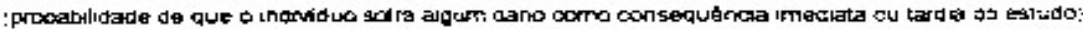

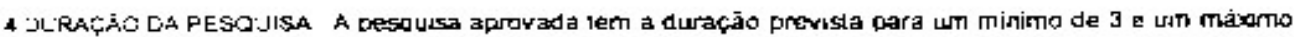
de $\equiv$ anos sermo o presente protocoto referente aperas ao pnmejro an da pesquisa. 


\section{INI - REGISTRD DAS EXPLICACGESS DO PESQIJISADOR AO PACIENTE OU SEU REPRESENTANTE LEGAL SOBRE A PESQUISA, CONSIGNANDO;}

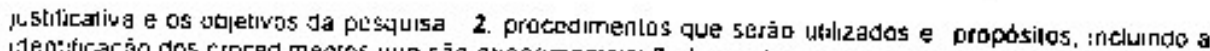
IJen:ificaçäo dos froced mencos liue sāo experimentals; 3. descontoriss e nscos esceradas: 4 benefigios LLe poderajo se: notıdos. 5. Frecedimenios altemativos que oossars ser vantajosos para o dnividuo

i A resposia aue vem senda renseguica cem o tialairlento oferecida na rede púbica de sairde as pessoas

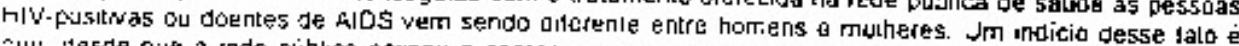
GuL, sesde que a rede jublica passais a con:as تom os modemes medicarmentos gntrirass. a mortatidade

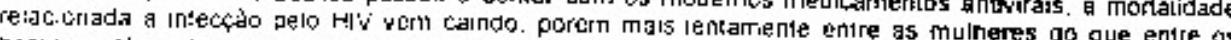
homeris alem dissu. apesar dos rielos de diagriostico e tratamenlos ja disponivels. as mulheres HIV

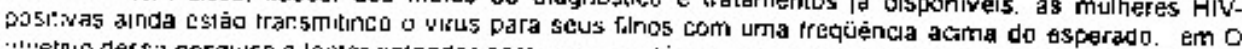

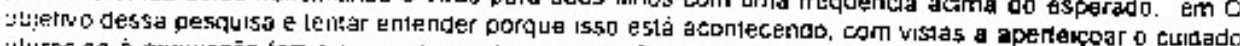

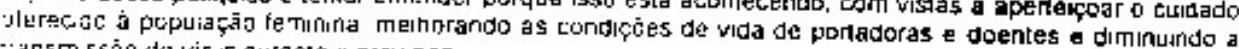
:arsm.ssajo do vir:js ju:an:e a gravioez

2 Com esse propos-lo seräo fellas enirevistas com mulheres poragoras e doentes de AlDs a1endidas em alguils serviços im:ponainles das aldades de Sanios e SAo Palo que volunlanamente se dispuserem a oesp

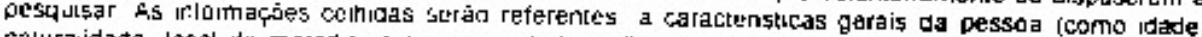
náluraidade, local de moradia, empiego estado crvil. etc.j, Jados sobre a históna da infeccáa e/ou abença (forma provavel de intecrabs, como tol 0 aldagnísico. como evolutu, etc.) e dados sobre o cuidado que recebeu nos civerscs senvcos de saujde em que fol alenduda nos úlimos anos Com essas intormaçōes procurationos icenlificar se existem caracteristenas que possamos anas. Com essas dificuldades no culdace a 5 ajce. que ipos de dificuldades $5 a ̄ 0$ cessas, e como poderiam ser evitadas ou dirintugas.

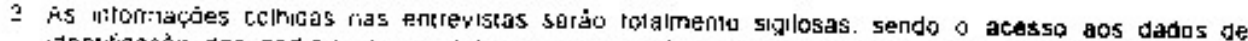
identeficaçac das particicariles estrito aos responsave:s pela pespuisa. Pode haver o desconfarla psiovico elou emocicnal ao falar re temas irilimos e algurrias vezes tnstes ou embarecosos para a paiticupante Mas será dado à volurilár:a 101a liberdade para nảo responder quałquer pergunta por juąlquer razāo, e sempre ine sera faculiado o direıto de desistir de oartsibar do estudo a qualquet

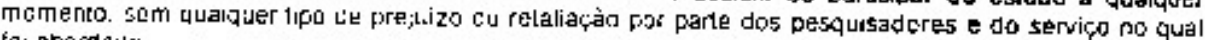
for abordaba.

\section{IV - ESCLARECIMENTOS DADOS PELO PESGUISADOR SOBRE GARANTIAS}

\section{DO SLJE|TO DA PESOUISA:}

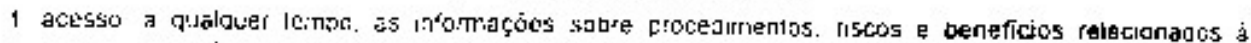

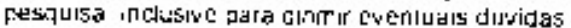

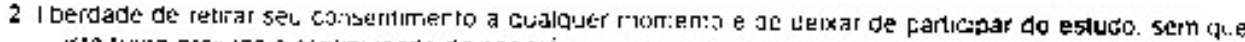
Is:0 :ıdja firejuzc a cur:tır.uic,jde da assistćricia.

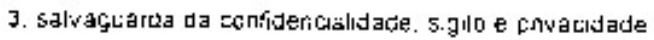

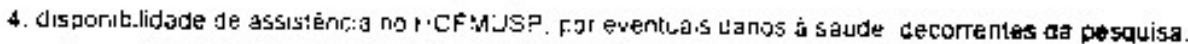

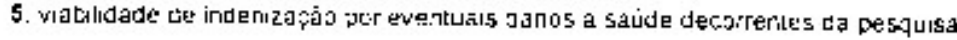




\section{ANEXO III}

V. INFORMACOES DE NOMES, ENDERECCOS E JELEFONES DOS RESPONSAYEIS PELO ACOMPANMAMENTO DA PESDUISA, PARA CONTATO EM CASO DE INTERCORRËNCIAS CLINICAS E REAÇOES ADVERSAS.

V1. OBSERVAÇŌES COMPLEMENTARES.

\section{VII - CONSENTIMENTO POS-ESCLARECIDO}

Dec-sro que. após convenientemente esclasecido reso pesquisadgr e ter emendida o que me for explicado. consintc em participar do presente Protocolo de Pespuisa

se te 19 
ANEXO IV

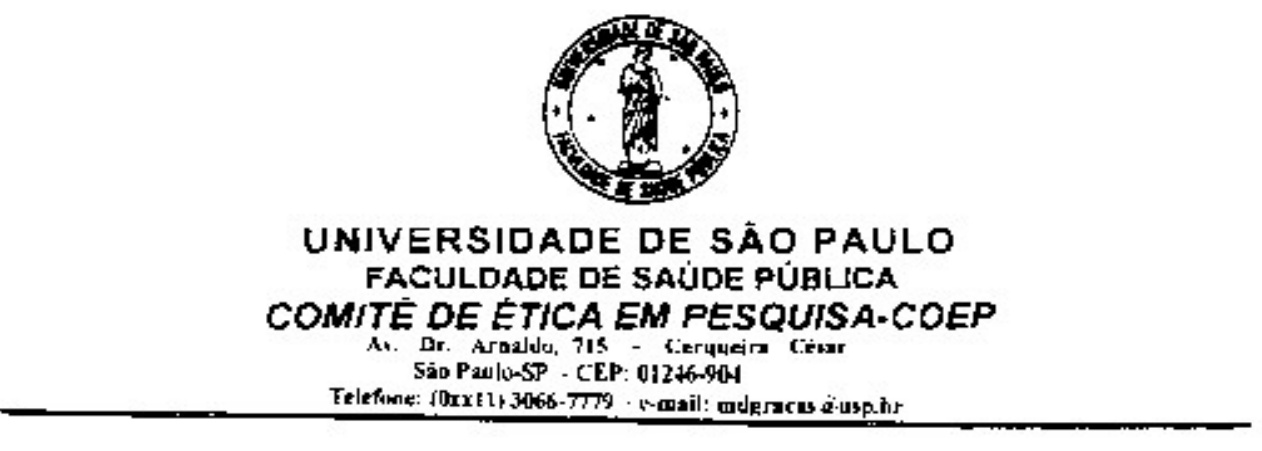

Of. COLP/037/01

21 de março de $200 \mathrm{i}$

Pelo presente. informo que o Conite de ritica ern Pcsqujsa da Fatuldade de Saúde Püblica da Universidade de Säo Paulo-COEP, analisou e aprovou. en sua $2 \%$ Sessāo Ordidária. de 20.03.0k, de acordo com ds requisitos da Rẹsoluçào CAS/196496, O Protocolo de Pesquisa n." 431, intitulado: "TRANSIrtanido ENTRE O VERMELHO E O PRETO: UTILIZNALO A YARLAVEL COR DA PELE COMO INDICADOR DE VLLNERAEIIIDADE AO HIV/AIDS EM SERVICOS DE REFERĖNCIA DA CDADE DE SÄO PAUIO. BRASIL", apresentadu pela pesquasadora Fcrnanda Lopes

Alenciosamente.

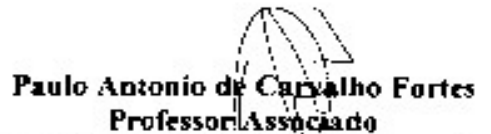

Professorlassacíado

Vice-Coordenador do Comilè de-Étichern Pesquisa da FSP-COF.P 